Viviane Siqueira Rodrigues

\title{
O Processo Coletivo para a Defesa dos Direitos Individuais Homogêneos
}

Dissertação de mestrado

Orientador: Prof. Dr. Flávio Luiz Yarshell

Faculdade de Direito da Universidade de São Paulo

São Paulo

2012 
Viviane Siqueira Rodrigues

\section{O Processo Coletivo para a Defesa dos Direitos Individuais Homogêneos}

Dissertação para obtenção do título de mestre perante a Faculdade de Direito da Universidade de São Paulo, na área de concentração de Direito Processual, sob orientação do Prof. Dr. Flávio Luiz Yarshell

Faculdade de Direito da Universidade de São Paulo

São Paulo 
Banca Examinadora

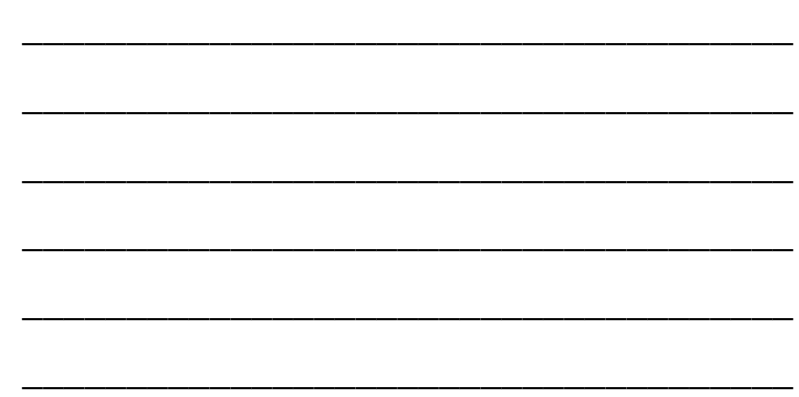


Agradecimentos

Aos meus pais, Nilva e Frederico, pelo incansável apoio e por representarem em minha vida exemplos de ternura e dedicação.

Aos meus irmãos, Frederico e Vanessa, pela paciência e compreensão.

Ao Professor Flávio, por confiar em mim como aluna, e cumprir de forma exemplar o digno papel de professor. 


\section{SUMÁRIO}

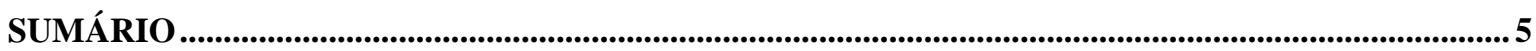

RESUMO_.................................................................................................................................................................

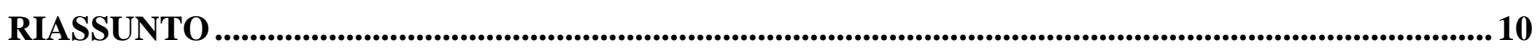

INTRODUÇÃO

PARTE I - PROCESSO CIVIL COLETIVO E OS DIREITOS INERENTES À SOCIEDADE PÓS-

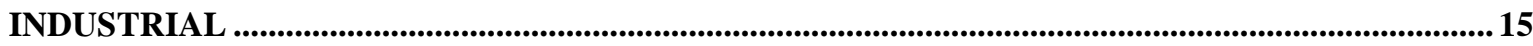

1. Evolução do processo civil coletivo: escorço histórico de sua idealização, introdução e sistematização

1.1. A necessidade de revisita do modelo tradicional de processo civil e o nascer do modelo social de

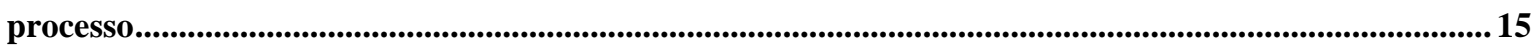

1.2. Fundamentos político-sociais do surgimento do novo modelo de processo civil.................................... 18

1.3. Retrospecto da legislação brasileira acerca da tutela dos interesses supraindividuais ....................... 19

1.4. A otimização do acesso à justiça e os contornos do novo modelo de processo civil (public law litigation ou processo de interesse público)..........................................................................................................23

1.5. Um ramo autônomo do direito processual que tende à afirmação da cidadania e da democracia ..30

2. Interesses envolvidos em ações coletivas na perspectiva do direito brasileiro..........................................33

2.1. Interesses difusos...............................................................................................................................36

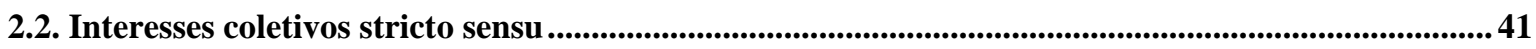

2.3. Interesses individuais homogêneos ...................................................................................................... 43

PARTE II - O PROCESSO COLETIVO PARA O TRATAMENTO DOS DIREITOS INDIVIDUAIS HOMOGÊNEOS NO ORDENAMENTO BRASILEIRO..............................................................................51

1. Legitimação para agir ..................................................................................................................................51

1.1. Natureza. Legitimação extraordinária .......................................................................................................51

1.2. Legitimação exclusiva. A questão da ilegitimidade coletiva do membro do grupo ...............................58

1.3. Legitimação concorrente e disjuntiva: a escolha pelo modelo misto proposto por Cappelletti ........62

1.4. Entes legitimados .................................................................................................................................6

1.4.1. Defensoria Pública ................................................................................................................................................... 64

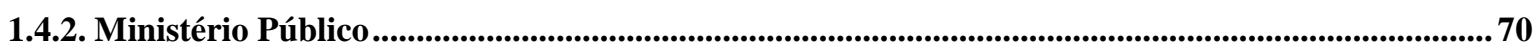

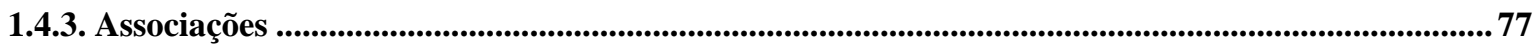




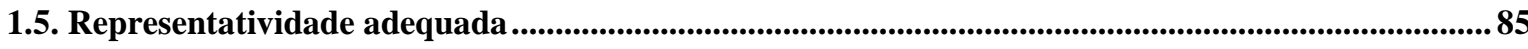

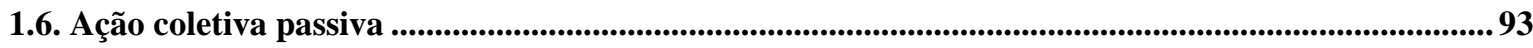

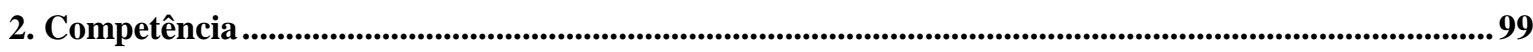

2.1. Competência para o processamento de ações coletivas versando direitos individuais homogêneos. Análise do alcance dos artigos $2^{\circ}$ da Lei 7.347/85 e 93 do Código de Defesa do Consumidor.

3. Prova 107

3.1. Ônus de provar e inversão 107

4. Coisa julgada 115

4.1. Conceito de coisa julgada e distinção entre efeitos da sentença e autoridade da coisa julgada ..... 115

4.2. Limites subjetivos da coisa julgada e a coisa julgada erga omnes 117

4.2.1. Coisa julgada secundum eventum litis e secundum eventum probationis 122

4.3. Transporte da coisa julgada in utilibus

4.4. A limitação territorial da coisa julgada segundo a Lei 9.494/97

5. Relação dos processos coletivos entre si e com as pretensões individuais e suspensão dos processos individuais

6. Sentença genérica e procedimento para liquidação e execução da sentença coletiva 141

6.1. Sentença genérica.

6.2. Procedimento para liquidação e execução 145

6.3. Fluid recovery e o fundo criado pela Lei $7.347 / 85$ 150

PARTE III - OUTRAS TÉCNICAS DE RESOLUÇÃO DOS LITÍGIOS DE INTERESSES INDIVIDUAIS HOMOGÊNEOS NO DIREITO VIGENTE E PROJETADO 154

1. Improcedência da demanda com fulcro no art. 285-A do CPC e súmula impeditiva de recursos.... 154

2. Incidente de resolução de demandas repetitivas 158

3. Arbitragem 163

4. Transação 168

PARTE IV - PROCESSO COLETIVO EM DEFESA DE INTERESSES INDIVIDUAIS HOMOGÊNEOS NA EXPERIÊNCIA ESTRANGEIRA

1. Europa 171

1.1. A preocupação da União Européia com a tutela dos consumidores . 171 
1.3. Itália e as ações coletivas para a tutela dos consumidores. 176

2. Estados Unidos da América e as class actions for damages 179

3. Ibero-América . 181

3.1. Colômbia e as ações de grupo 181

3.2. Província de Rio Negro (Argentina) e as ações coletivas 184

PARTE V - OBSERVAÇÕES CRÍTICAS E CONCLUSÕES 186 


\section{RESUMO}

O escopo deste trabalho é examinar o processo coletivo destinado à defesa dos direitos individuais homogêneos e os meios paralelos de solução dos litígios de massa. Foi descrito o momento histórico no qual se insere a tutela dos interesses transindividuais e, precisamente a tutela coletiva dos direitos individuais, estabelecendo a conexão entre a sociedade pós-industrializada, a massificação das relações intersubjetivas e a busca da ciência processual por eficiência. Também descrevemos a evolução legislativa no tocante à tutela coletiva no direito brasileiro. Valendo-nos do desenvolvimento teórico em torno das categorias de direitos transindividuais, identificamos o objeto de estudo, alcançando então a natureza, características e dimensões dos chamados interesses individuais homogêneos. Então, sob uma ótica orgânica, foram debatidos os temas centrais que envolvem esse modelo de processo coletivo, à luz das normas constitucionais, das Leis n. 4.717/65, 7.347/85 e 8.078/90, que reunidas compõem o microssistema processual coletivo, e do direito projetado (Projeto n. 5139/2009) e comparado (Código Modelo de Processos Coletivos para a Ibero-América e outras experiências estrangeiras). Analisamos os temas da legitimidade, passando pelo rol de legitimados, requisitos da representatividade adequada e, também, pela legitimidade passiva do representante de direitos individuais homogêneos. Em torno da competência, expusemos os requisitos legais presentes no art. 93 do CDC, e apoiamos nossas considerações no espírito centralizador que, por razões de eficiência, deve guiar o manejo de ações coletivas. Quando nos dedicamos ao estudo da prova, vieram à lume a teoria das cargas dinâmicas do ônus da prova e o debate sobre o momento apropriado para a decisão sobre a inversão. Ao avançarmos para o tema da relação entre o processo coletivo e as ações individuais, passamos a analisar um dos mais relevantes aspectos da tutela coletiva dos interesses individuais homogêneos, que consiste na livre adesão do indivíduo à ação coletiva. Em torno da coisa julgada, defendemos a opção do legislador de 1990 pelo transporte secundum eventum litis da coisa julgada coletiva para a esfera individual. Mas observamos que, para a fase atual de desenvolvimento tecnológico e das organizações judiciárias, é muito positivo o paulatino caminhar para um modelo mais eficiente. Em continuação, examinamos os aspectos procedimentais da liquidação e da execução da sentença coletiva genérica. Alcançado o tema das outras técnicas de resolução dos conflitos de massa, preconizamos especial atenção do intérprete para o resguardo do objeto das ações coletivas. Então, foram buscadas as origens e os fundamentos de direito comparado para a improcedência prima 
facie da demanda com fulcro no art. 285-A do CPC, a súmula impeditiva de recursos e o incidente de resolução de demandas repetitivas. Ainda dentre as soluções heterocompositivas das controvérsias de massa, também foi estudada a arbitrabilidade dos direitos individuais homogêneos, na sua dimensão coletiva. O mesmo foi feito, por sua vez, no âmbito das soluções autocompositivas, com relação à transação. Por fim, dedicaram-se alguns capítulos à descrição das regras vigentes em alguns países ocidentais (Portugal, Itália, Estados Unidos da América, Colômbia e Argentina).

Palavras-chave: processo coletivo - direitos individuais homogêneos - técnica processual meios alternativos. 


\section{RIASSUNTO}

Lo scopo di questo lavoro è esaminare il processo collettivo destinato alla difesa dei diritti individuali omogenei e i mezzi paralleli di soluzione dei litigi di massa. Ł̀ stato descritto il momento storico in cui si inserisce la tutela degli interessi transindividuali e, precisamente, la tutela collettiva dei diritti individuali, stabilendo la connessione tra la società post-industrializzata, la massificazione delle relazioni intersoggettive e la ricerca della scienza processuale per efficienza. Abbiamo anche descritto l'evoluzione legislativa che riguarda la tutela collettiva del diritto brasiliano. Valendoci dello sviluppo teorico intorno alle categorie dei diritti transindividuali, abbiamo identificato l'oggetto di studio, raggiungendo così la natura, le caratteristiche e le dimensioni dei nominati interessi individuali omogenei. Dunque, in un'ottica organica, sono stati dibattuti i temi centrali che coinvolgono questo modello di processo collettivo, alla luce delle norme costituzionali, delle Leggi n. 4.717/65, 7.347/85 e 8.078/90, che riunite compongono il microsistema processuale collettivo, e del diritto progettato (Progetto n. 5139/2009) e comparato (Codice Modello di Processi Collettivi per l'Ibero-America e altre esperienze straniere). Abbiamo analizzato i temi della legittimità, passando per l'elenco dei legittimati, requisiti della rappresentanza adeguata e anche per la legittimità passiva del rappresentante di diritti individuali omogenei. Intorno alla competenza, abbiamo esposto i requisiti legali presenti nell'art. 93 del Codice del Consumo, e abbiamo appoggiato le nostre considerazioni sullo spirito centralizzatore che, per ragioni di efficienza, deve guidare la gestione di azioni collettive. Quando ci siamo dedicati allo studio della prova, sono venute alla luce la teoria dei carichi dinamici dell'onere della prova e il dibattito sul momento appropriato per la decisione sull'inversione. Dal tema della relazione tra il processo collettivo e le azioni individuali, abbiamo analizzato uno dei più rilevanti aspetti della tutela collettiva degli interessi individuali omogenei, che consiste nella libera adesione dell'individuo all'azione collettiva. Riguardo la cosa giudicata, abbiamo difeso l'opzione del legista del 1990 per il trasporto secundum eventum litis dalla cosa giudicata collettiva alla sfera individuale. Ma abbiamo osservato che, per la fase attuale di sviluppo tecnologico e delle organizzazioni giudiziarie, è molto positivo l'evolversi verso un modello più efficiente. Successivamente, abbiamo esaminato gli aspetti procedimentali della liquidazione e dell'esecuzione della sentenza collettiva generica. Raggiungendo il tema delle altre tecniche di risoluzione dei conflitti di massa, abbiamo preconizzato speciale attenzione dell'interprete per la cura dell'oggetto delle azioni collettive. Allora, sono state cercate le origini e i fondamenti di 
diritto comparato per l'improcedibilità prima facie della richiesta con fulcro nell'art. 285-A del Codice di Procedura Civile, il riassunto impeditivo di ricorsi e l'incidente di risoluzione di richieste ripetitive. Ancora tra le soluzioni eterocompositive delle controversie di massa, è stata anche studiata l'arbitrabilità dei diritti individuali omogenei, nella sua dimensione collettiva. Lo stesso è stato fatto nell'ambito delle soluzioni autocompositive, in relazione alla transazione. Infine, sono stati dedicati alcuni capitoli alla descrizione delle regole vigenti in alcuni paesi occidentali (Portogallo, Italia, Stati Uniti dell'America, Colombia e Argentina).

Parole chiave: Processo collettivo - diritti individuali omogenei - tecnica processuale mezzi alternativi. 


\section{INTRODUÇÃO}

O objetivo da presente dissertação consiste na análise orgânica e funcional do processo coletivo destinado à defesa dos direitos individuais homogêneos, suas principais vicissitudes, bem como seus reflexos na órbita de direitos de seus titulares.

Na perspectiva contemporânea da ciência processual, o processo está em pé de igualdade, em grau de importância, do direito objetivo dirigido aos componentes a uma comunidade jurídica. Mas não obstante a importância e a autonomia científica conquistada ao longo do tempo, é igualmente verdade que o processo ostenta um papel instrumental, tornando-se sempre relevante avaliar sua aptidão em cumprir sua tarefa e produzir os efeitos desejados, tal como o faria a norma abstrata.

Por isso é que se desenvolveu o trabalho de identificação dos escopos de atuação do poder jurisdicional, que servirão sempre de parâmetro para o exame do desempenho do processo segundo seu perfil instrumental.

Assim, se o poder jurisdicional atua quando o direito objetivo não é capaz de, por si só, incentivar a conduta esperada pelo ordenamento, o processo serve para a afirmação do direito. Atendendo a esse propósito, a função jurisdicional alcançou seu escopo jurídico. Por vias reflexas, a atuação do estado-juiz confirma a sua autoridade como corpo político cuja vontade sobrepõe à dos jurisdicionados (por força da substitutividade de suas decisões) servindo, dessa forma, então, para atender ao escopo político da jurisdição. Por último, e não menos relevante, sob a ótica social, o desenlace que o processo opera sobre a relação jurídica material, com a eliminação do conflito, atua, psicologicamente, no íntimo dos jurisdicionados, para conduzir à pacificação da sociedade.

Pondo em prática essa noção instrumental, deparamo-nos com a necessidade de observar o sistema processual a partir de uma perspectiva externa, com o empenho em situar o processo no contexto das realidades sociais da nação. Assim, a mola mestra desse ponto de vista é a consciência de que o processo está imerso na vida dos cidadãos e, por conseguinte, no "universo axiológico da sociedade a que destina", não sendo impermeável às ideologias e valores reinantes na comunidade.

\footnotetext{
${ }^{1}$ Cf. Cândido Rangel Dinamarco, Escopos Políticos do processo, in Participação e processo (coord. Ada Pellegrini Grinover, Cândido Rangel Dinamarco e Kazuo Watanabe), São Paulo, Revista dos Tribunais, 1988, pp. 115/127. Nicklas Luhmann, um dos expoentes do assunto dentre os juristas alemães, erige como
} 
Essas premissas metodológicas, de grande valia na atual fase da ciência processual, devem ser verdadeiras em todo e qualquer processo. Para que o processo atue como verdadeiro instrumento para se chegar a decisões justas e céleres (pacificação com justiça $^{2}$ ), não se dispensa uma constante mudança de mentalidade ${ }^{3}$ do operador do direito.

Atento, então, aos moldes da sociedade pós-industrial atual, examinada no corpo do trabalho, em que as violações ao ordenamento jurídico são produzidas em grande escala, o sistema processual sofreu grandes transformações orgânicas tendentes a proteger e, se o caso, ressarcir os direitos inerentes a inúmeras pessoas. Ocorre que não bastaria a abertura da porta de entrada ao Judiciário, para permitir o simples acesso à justiça, se essa iniciativa não proporcionasse aos inúmeros interessados ou titulares do direito violado em massa o acesso qualificado à justiça.

Precisamente sob essa ótica é que se propõe o exame orgânico do processo judicial concebido para essa finalidade de resolução de conflitos de massa, sem ignorar, por sua vez, a necessidade de posicionar as soluções paraestatais nesse esquema de promoção da ordem jurídica justa ${ }^{4}$.

Ainda, lembrando a lição de que o processo é imerso na vida das pessoas e, na atual realidade, tornou-se um fenômeno social de massa ${ }^{5}$, teremos o cuidado de considerar as garantias da igualdade e da celeridade da tutela jurisdicional e de que maneira elas influem no tratamento dos conflitos de massa.

Por fim, sempre buscando identificar aspectos comuns e divergentes na experiência estrangeira, analisando o desenvolvimento da ciência processual nesse aspecto dos direitos massificados nos países com técnicas processuais específicas e de notoriedade no cenário internacional do Ocidente. Nesse propósito, procuramos lembrar sempre do importante alerta do Professor Carlos Alberto de Salles de que "o mérito das análises comparativas não está em buscar a importação de soluções, mas na obtenção de parâmetros

propósitos da jurisdição "garantia jurídica e paz legal" (Legitimação pelo procedimento, Brasília, UNB, 1981, p. 21).

${ }^{2}$ Flávio Luiz Yarshell, Tutela jurisdicional específica nas obrigações de declaração de vontade, São Paulo, Malheiros, 1993, p. 17.

${ }^{3}$ Com a desmistificação de certos dogmas construídos a partir de um ponto de vista introspectivo do processo, ele é colocado "em seu devido lugar de instrumento que não pretenda ir além de suas funções; "instrumento cheio de dignidade e autonomia científica, mas nada mais do que instrumento"" (cf. Cândido Rangel Dinamarco, Instrumentalidade do processo, 11 a ed., São Paulo Malheiros, 2003, p. 329 e 331).

${ }^{4}$ Kazuo Watanabe, Da cognição no processo civil, São Paulo, Revista dos Tribunais, 1987, p. 17.

${ }^{5}$ José Rogério Cruz e Tucci, Class action e mandado de segurança coletivo, São Paulo, Saraiva, 1990, p. 2. 
aptos a permitir uma melhor avaliação do direito nacional estudado, com a identificação de falhas e aporte de elementos para construção de alternativas viáveis"6.

Assim, objetivamos contribuir com uma despretensiosa sistematização do processo coletivo destinado à defesa de interesses surgidos a partir das relações jurídicas de massa, com considerações críticas sobre o atual estado legislativo bem como o direito projetado a respeito de outras técnicas processuais visando à solução de controvérsias envolvendo direitos individuais homogêneos.

Para alcançar esse objetivo, o trabalho se dedicou à análise de seus componentes essenciais, como sujeitos, objeto (tanto internamente considerado, quanto sob um ponto de vista externo, para estudar as relações deste com outros processos), o local de processamento e julgamento da demanda coletiva, modalidades de provimentos judiciais, efeitos de suas decisões, autoridade da coisa julgada e modo de cumprimento ou efetivação.

No ensejo, também procuramos analisar as técnicas vigentes e projetadas, dissociadas do processo coletivo, para a solução de demandas repetitivas ou de proteção de direitos individuais homogêneos, tais como o incidente de coletivização de demandas, o decreto de improcedência liminar com fulcro no artigo 285-A do Código de Processo Civil, e a súmula impeditiva de recursos.

Por fim, também como já mencionado, realizamos um estudo de direito comparado, em países do Ocidente com algum nível de desenvolvimento nos meios de defesa dos direitos individuais homogêneos, a fim de avaliar o atual estado da técnica legislativa a respeito.

Em linhas gerais, essa é a nossa proposta à qual nos dedicamos nas páginas que seguem.

\footnotetext{
${ }^{6}$ Cf. Ações coletivas: premissas para comparação com o sistema jurídico norte-americano, in Processos coletivos e tutela ambiental (org. Carlos Alberto de Salles et. al.), Santos, Universitária Leopoldianum, 2006, p. 19. De forma semelhante, a Professora Elisabetta Silvestri, da Universidade de Pavia, argumentou em texto recente que o modelo mais célebre da class action é "portável" e pode ser aproveitado em outros ordenamentos jurídicos, inclusive de civil law, mas precisa ser abandonada a ilusão de que, na forma em que delineado na common law norte-americana, se trata de um bicho de sete cabeças ("Frankenstein monster") ou de um príncipe encantado ("knight in shining armor") e ser lembrado que o procedimento nunca é transplantado sozinho e pode sofrer rejeições implícitas ou explícitas pelo ordenamento destinatário (cf. The difficult art of legal transplants: the case of class actions, in Revista de Processo, vol. 187, setembro de 2010, p. 99, disponível em Revista dos Tribunais on line)
} 


\section{PARTE I - PROCESSO CIVIL COLETIVO E OS DIREITOS INERENTES À SOCIEDADE PÓS-INDUSTRIAL}

\section{Evolução do processo civil coletivo: escorço histórico de sua idealização, introdução e sistematização}

\subsection{A necessidade de revisita do modelo tradicional de processo civil e o nascer do modelo social de processo}

Sob a égide da clássica summa divisio entre direito público e privado, todo tipo de conflito era levado a juízo por meio de um modelo de processo, concebido para a solução de controvérsias bipolarizadas ${ }^{7}$. Assim, os litígios em que se contrapunham interesse do Estado e do indivíduo, ou de interesse público, e também os litígios envolvendo interesses estritamente de particulares, ou de interesse privado, se comportavam do mesmo modo.

Tratava-se de modelo de processo típico de uma sociedade pré-industrial, influenciada pelos dogmas das revoluções burguesas do século XVIII, momento no qual as preocupações com a coletividade eram deixadas de lado pelo corpo social. Nesse período, o Estado e o indivíduo eram os exclusivos protagonistas do cenário judicial. Quando não se falava em juízo de algum interesse estritamente particular, o debate sobre a índole pública de dado bem jurídico não ia além da referência ao mero interesse fazendário, desapegandose da noção de patrimônio comunitário.

Esse distanciamento dos órgãos estatais de tudo que não dizia respeito ao tesouro era inerente ao Estado Liberal, notável pela intervenção mínima na vida social. Por exigência das burguesias que repudiavam o autoritarismo do Antigo Regime, imperava, portanto, na época que se seguiu ao absolutismo, a passividade estatal.

Nas últimas décadas do século XX consolidou-se o chamado Estado Social, preocupado com a judicialização de interesses antes marginalizados da tutela estatal. A respeito desse cenário político-histórico, Pedro Lenza assevera que, o Estado "apresenta-se como o grande responsável pela harmonização social e assegurador de alguns direitos que

\footnotetext{
${ }^{7}$ Rodolfo de Camargo Mancuso, Interesses difusos: conceito e legitimação para agir, 6 ${ }^{\mathrm{a}}$ ed., São Paulo, Revista dos Tribunais, 2004, p. 36.
} 
vinham sendo mutilados pela fúria capitalista da Revolução Industrial”, emergindo, assim, o chamado Estado Assistencial ${ }^{8}$.

A própria expressão "interesse público", da dicotomia clássica, tornou-se equívoca ${ }^{9}$, designando por vezes um interesse da pessoa jurídica estatal (em caráter primário ou secundário) e em outras situações um interesse geral, ou de uma dada coletividade. $\mathrm{Na}$ sociedade massificada, evidenciou- $\mathrm{se}^{10}$ uma categoria intermediária de interesses que, ao lado de se relacionar com alguns dos objetivos estatais, não oferecia com facilidade a identificação de seus titulares.

Ilustrando esse aspecto, tornou-se problemática, sob a ótica do processo tradicional, a solução de litígio envolvendo, de um lado, fábricas emissoras de poluentes na atmosfera ou em águas fluviais e, de outro, determinada comunidade adjacente ou entidade de defesa dos valores atinentes ao meio ambiente, ou ainda, a violação em massa aos direitos de consumidores lesados por cláusulas abusivas incluídas em contrato de adesão subscritos por uma infinidade de sujeitos.

O uruguaio Enrique Vescovi, que se destacou na doutrina sul-americana no estudo do tema, enfatizou o paradoxo evidenciado pela sociedade contemporânea de massa entre a maior disponibilidade de bens e serviços e, em contrapartida, a maior dificuldade na sua fruição ${ }^{11}$.

Nesse novo cenário, de relações interpessoais sofisticadas em que os conflitos apresentam configuração subjetiva altamente complexa e desconcentrada, o processo civil vocacionado à solução do conflito do modelo Caio versus Tício mostrou-se impotente.

Nas palavras de Ada Pellegrini Grinover, que entre nós é um dos maiores expoentes no estudo dessa matéria, "não bastava reconhecer os direitos de solidariedade.

\footnotetext{
${ }^{8}$ Cf. Pedro Lenza, Teoria geral da ação civil pública, $3^{\text {a }}$ ed., São Paulo, Revista dos Tribunais, 2008, p. 29.

${ }^{9}$ Hugo Nigro Mazzilli, A defesa dos interesses difusos em juízo, 22 a ed., São Paulo, Saraiva, 2009, p. 48.

${ }^{10}$ Não se fala do "surgimento" desses interesses, pois é sabido que "o meio ambiente, o consumidor (...), o patrimônio cultural e outros interesses metaindividuais sempre existiram. O que não havia, isso sim, eram instrumentos processuais adequados, para que as suas tutelas fossem deduzidas em juízo" (cf. José Marcelo Menezes Vigliar, Tutela jurisdicional coletiva, São Paulo, Atlas, 1998, pp. 16/17).

11 "mientras que por un lado se acentúan las diferencias - en la mayoría de los países - entre ricos y pobres y por tanto estos últimos (como los países en vías de desarrollo) quedan en mayor retraso en cuanto al acceso a los diversos bienes y servicios; por otro lado, cada vez participan en dichos bienes, aunque sea precariamente, una mayor cantidad de la población, o sea que hay por un lado un mayor número de personas que van adquiriendo conciencia de sus derechos (al menos de los más elementales) y reclamando el goce de los mismos, a la vez que dicho goce se va haciendo más difícil de alcanzar, al menos a quienes carecen de posibilidades económicas" (cf. Enrique Vescovi, Manual de Derecho Procesal - Actualizado según el Código General del Proceso, Montevidéu, Idea, 1990, pp. 357/358).
} 
(...) como cabe ao direito processual atuar praticamente os direitos ameaçados ou violados, a renovação fez-se, sobretudo, no plano do processo" ${ }^{\prime 2}$.

Então, sob a premissa de que o instrumento processual deve ter aptidão para a realização tanto quanto possível do direito substancial, os processualistas contemporâneos se engajaram na tarefa de construir um modelo adequado à nova realidade social $^{13}$. Notadamente nos países de tradições romano-germânicas, foi a partir do Congresso realizado em Pavia, na Itália, em $1974^{14}$, para o qual contribuíram intensamente Cappelletti, Denti, Pisani, Vigoriti e Trocker, que essa mentalidade ganhou espaço metodológico.

Segundo Cappelletti, um dos grandes nomes do movimento pelo acesso à justiça dos "novos" interesses, essa empreitada consistiu numa "radical revisão da ciência inteira do Direito Processual" ${ }^{15}$ a fim de que fosse concretizada em benefício das novas formações sociais a promessa constitucional da inafastabilidade da jurisdição, merecedora de tamanha estima dos processualistas contemporâneos.

Valendo-se dessa nova configuração do processo, "o que aparecia inicialmente como mero interesse elevou-se à dimensão de verdadeiro direito, conduzindo à reestruturação de conceitos jurídicos que se amoldassem à nova realidade" ${ }^{" 16}$. Assim, ao lado dos clássicos interesses privados e públicos (estes últimos resumidos àqueles detidos por pessoas jurídicas de direito público), ganharam tratamento constitucional aqueles outrora denominados como meros interesses legítimos e que apenas reflexamente

${ }^{12}$ Cf. Ada Pellegrini Grinover, Significado social, político e jurídico da tutela dos interesses difusos, in Revista de Processo, n. 97, p. 10. Confira-se também: José Carlos Barbosa Moreira, Tendências contemporâneas do direito processual civil, in Temas de Direito Processual Civil - Terceira Série, São Paulo, Saraiva, 1984, pp. 1/13, em que o autor tratou do desenvolvimento da ciência do processo "do individuo ao social", a partir do estudo da influência da legislação austríaca de 1895 (Zivilprozessordnung) nos trabalhos de revisão legislativa sobre o "processo social".

${ }^{13}$ Dierle José Coelho Nunes denominou o fenômeno de socialização do processo (Processo jurisdicional democrático, Curitiba, Juruá, 2009, pp. 115/116).

${ }_{14}$ É praticamente uníssona a afirmação de que, nos países da família da civil law, foi a partir da década de 1970 que os estudiosos se aprofundaram no estudo da tutela coletiva. Não obstante, Giuseppe Tarzia faz referência às obras de Emilio Bonaudi (La tutela degli interessi collettivi) e Ugo Ferrone (Il processo civile moderno - fondamento progresso e avvenire), datadas de 1911 e 1912, respectivamente, e dedicadas à análise dos interesses coletivos e à l'azione degli enti, com a previsão do último de que uma produção legislativa não poderia tardar para a proteção concreta dessa modalidade de interesses (Giuseppe Tarzia, in Participação e processo cit., pp. 52/53).

${ }^{15}$ Cf. Mauro Cappelletti, Formações sociais e interesses coletivos diante da justiça civil, São Paulo, Revista de Processo, n. 5, janeiro a março de 1977, p. 128.

${ }^{16}$ Cf. Ada Pellegrini Grinover, A ação civil pública refém do autoritarismo, in O processo - estudos e pareceres, DPJ, São Paulo, 2005, p. 237. 
apareciam no cenário judicial, ao mesmo tempo em que, para defender em juízo tais interesses supraindividuais, institucionalizaram-se as figuras dos entes ideológicos.

A seguir, além das características e das funções essenciais do novo modelo de processo, serão estudados mais detidamente os seus fundamentos sociais e políticos bem como a introdução desse novo paradigma no ordenamento jurídico-processual brasileiro.

\subsection{Fundamentos político-sociais do surgimento do novo modelo de processo civil}

O estudo da realidade sociopolítica que se encontra no entorno de uma revolução jurídica é sempre útil à compreensão e à melhor aplicação dos novos institutos e da nova estrutura jurídica. Por isso desenvolveremos um pouco mais a identificação do fundamento das transformações pelas quais passou o processo nas recentes décadas e que serão tratadas neste trabalho.

Com esse propósito, constata-se que a sociedade contemporânea dotada de um processo produtivo e de distribuição de bens em massa deu origem a conflitos mais complexos que, como já acenado, não tinham espaço no cenário forense. Os interesses oriundos dessa nova configuração social passaram a ser despersonificados e também as responsabilidades pelas lesões aos direitos se disseminaram, acompanhando o fenômeno de desconcentração dos interesses, com as chamadas violações de massa ${ }^{17}$.

Ao lado do fenômeno social, os ordenamentos de grande parte dos Estados contemporâneos proclamaram proteção aos direitos metaindividuais ${ }^{18}$, oriundos das relações de consumo, de trabalho, ou do meio ambiente, do mercado concorrencial, do patrimônio cultural etc.

Rodolfo de Camargo Mancuso, também intensamente dedicado à análise dessa quebra de paradigma, identificou o nascimento da consciência do coletivo no corporativismo da Idade Média, quando os corpos intermediários constituíam novos focos

\footnotetext{
${ }^{17}$ Cappelletti, Formações cit., p. 130, Barbosa Moreira, Ações coletivas na Constituição Federal de 1988, in, Revista de Processo, n. 61, janeiro a março de 1991, pp. 187/200, especialmente p. 187. Segundo Rodolfo de Camargo Mancuso, a coletivização é instintiva e inevitável e, para esse autor, é até mesmo anterior à sociedade de massa (Interesses difusos cit., $6^{\mathrm{a}}$ ed., p. 42).

18 "a possibilidade de construir-se tipos novos de tutela, não confiados exclusivamente ao interesse material e ao capricho da iniciativa individual. Mesmo a procura destes tipos novos de tutela é, acredito, aquilo que mais profundamente está caracterizando a evolução do Direito judiciário na época contemporânea" (cf. Cappelletti, Formações cit., p. 132).
} 
de poder localizados entre o público e o $\operatorname{privado}^{19}$. Mas, dada passividade do Estado Liberal, não se nega que é a partir do amadurecimento do Estado Social que os direitos metaindividuais chegaram à pauta do Judiciário ${ }^{20}$.

Portanto, é possível afirmar que o novo modelo de processo civil encontra fundamento social na massificação das relações intersubjetivas e fundamento político na preocupação do Estado com os direitos sociais.

\subsection{Retrospecto da legislação brasileira acerca da tutela dos interesses supraindividuais}

Como já ressaltado, a dificuldade de se identificar o titular dos novos direitos evidenciados pela sociedade de massa impôs a superação da summa divisio que "se revela impotente diante dos direitos que pertencem, ao mesmo tempo, a todos e a ninguém" ${ }^{\prime 2}$. Desde o despertar do Estado para a necessidade de perseguir interesses de toda a comunidade, o direito substancial já se aperfeiçoava às novas conformações sociais e, transcendendo à índole individualista projetada no Código Civil de 1916 e encampada, principalmente, nos artigos $6^{\circ}$ e $472^{22}$ do atual Código de Processo Civil, o instrumento deveria acompanhar essa evolução $0^{23}$.

\footnotetext{
${ }^{19}$ Interesses cit., 6 a ed., p. 38.

20 "foi apenas em tempo mais recente que novas 'sociedades intermediárias' começaram a emergir e a proliferar. Novos grupos, novas categorias e classes individuais sabedoras de sua comunhão de interesses e necessidades, como, também, do fato de que somente unindo-se podiam superar sua debilidade, começaram a unir-se, para protegerem-se contra os novos despotismos de nossa época: a tirania da maioria; a opressão da moderna corporate society; o relaxamento ou a corrupção dos burocratas; o cego egoísmo dos poluidores..." (cf. Cappelletti, Formações cit., p. 148). Ainda: Cappelletti e Garth, Acesso à justiça (tradução de Ellen Gracie Northfleet), Porto Alegre, Sergio Antonio Fabris, 2002, pp. 70/71: "a enorme demanda latente por métodos que tornem os novos direitos efetivos forçou uma nova meditação sobre o sistema de suprimento - $\mathrm{o}$ sistema judiciário". Também a esse propósito: Nicolò Trocker, Gli interessi diffusi nell'opera della giurisprudenza, in Rivista Trimestrale di Diritto e Procedura Civile, ano XLV, 1987, p. 1113, com referências a comportamentos pluri-ofensivos (emissões nocivas, difusão de produtos danosos etc.) ligados ao desenvolvimento da moderna sociedade industrial e aos seus aspectos degenerativos, apud Paulo Duarte, Recurso e acórdão do Supremo Tribunal de Justiça de Portugal - Ação popular e interesses individuais homogêneos (colaboração de Ada Pellegrini Grinover), in Revista de Processo, n. 88, v. 22, outubro a dezembro de 1997, p. 134.

${ }^{21}$ Cf. Cappelletti, Formações cit., p. 135.

${ }^{22}$ A limitação subjetiva inter partes da coisa julgada é nota marcante do liberalismo e encontra respaldo na cláusula do due process of law: "La disposizione ha un preciso fondamento costituzionale nel precetto del due process of law, alla luce del quale sarebbe costituzionalmente illegittimo un accertamento giurisdizionale reso al termine di un giudizio in cui gli interessati non hanno avuto una possibilità seria ed effettiva di difendersi" (cf. Vigoriti, Interessi collettivi e processo: la legitimazione ad agire, Milão, Giuffrè, 1979, p. 272).

23 “as preocupações dos processualistas não podem limitar-se ao campo puramente processual. A formulação de conceitos e regras de processo deve atender à realidade social e às necessidades dos consumidores dos serviços jurisdicionais. Exemplos evidentes dessa flexibilização encontramos em novos instrumentos processuais, como o mandado de injunção, a ação civil pública para a defesa dos interesses difusos e
} 
Ada Pellegrini Grinover ${ }^{24}$ observa que uma nova categoria de interesse, estranha ao interesse público e ao interesse privado, no Brasil, foi regulamentada pela primeira vez em 1977, com uma nova redação ao artigo $1^{\circ}$ da Lei da Ação Popular, que incluiu no rol de bens tuteláveis judicialmente o patrimônio público, entendido também como patrimônio artístico, estético, histórico e turístico ${ }^{25}$ e não apenas como o erário de interesse fazendário.

A partir daí, segundo a doutrina, emergiu no Brasil a tutela por aquele terceiro gênero de interesses, antes tratados como interesses legítimos ou interesses ocasionalmente protegidos e de pouquíssimo prestígio judicial ${ }^{26}$, localizado a meio caminho entre o interesse privado e o interesse público, "daí a necessidade de superar a rígida divisão entre o público e o privado",27.

No Brasil, portanto, foi a partir de 1977, com a mencionada alteração da Lei da Ação Popular, que se superou a necessidade teórica de classificar alguns interesses metaindividuais como meros interesses legítimos, pois ganharam força de verdadeiros direitos metaindividuais ${ }^{28}$.

coletivos, os Juizados Especiais. Verifica-se, pois, a necessidade premente de conscientização do processualista no sentido de que sua ciência, não obstante autônoma, só tem sentido se servir de maneira eficaz a seu objeto" (cf. José Roberto dos Santos Bedaque, Direito e processo - influência do direito material sobre o processo, $5^{\mathrm{a}}$ ed., São Paulo, Malheiros, 2009, pp. 72/73).

${ }^{24}$ Significado social cit., pp. 9/11.

25 "Art. $1^{\circ}$ - Consideram-se de interesse turístico as Áreas Especiais e os Locais instituídos na forma da presente Lei, assim como os bens de valor cultural e natural, protegidos por legislação específica, e especialmente: I - os bens de valor histórico, artístico, arqueológico ou pré-histórico; II - as reservas e estações ecológicas; III - as áreas destinadas à proteção dos recursos naturais renováveis; IV - as manifestações culturais ou etnológicas e os locais onde ocorram; V - as paisagens notáveis; VI - as localidades e os acidentes naturais adequados ao repouso e à pratica de atividades recreativas, desportivas ou de lazer; VII - as fontes hidrominerais aproveitáveis; VIII - as localidades que apresentem condições climáticas especiais; IX - outros que venham a ser definidos, na forma desta Lei".

${ }^{26}$ Segundo Mancuso, a proteção aos interesses legítimos ocorria por via reflexa, na hipótese em que a norma protetora de um outro interesse irradiasse sua proteção a um titular não necessariamente beneficiado pela norma, desde que de maneira consentânea e congruente com o sistema jurídico (Interesses cit., $6^{\mathrm{a}}$ ed.; pp. 78/79). Susana Henriques da Costa acentua que se tratava de proteção indireta e eventual ( $O$ processo coletivo na tutela do patrimônio público e da moralidade administrativa, São Paulo, Quartier Latin, 2009, p. 46).

${ }^{27}$ Vide: Paulo Henrique dos Santos Lucon, Daniela Monteiro Gabbay, Rafael Francisco Alves e Tathyana Chaves de Andrade, Interpretação do pedido e da causa de pedir nas demandas coletivas (conexão, continência e litispendência), in Tutela Coletiva - 20 anos da Lei da Ação Civil Pública e do fundo de defesa dos interesses difusos, 15 anos do Código de Defesa do Consumidor, São Paulo, Atlas, 2006, p. 187.

${ }^{28}$ Sob uma perspectiva sócio-política, Ada Pellegrini Grinover menciona que a judicialização dos chamados interesses transindividuais ensejou o nascimento de uma "soberania social atribuída aos grupos naturais e históricos que compõem a nação" como uma nova forma de limitação do poder estatal com grande repercussão na teoria das liberdades públicas (cf. Novas tendências em matéria de legitimação e coisa julgada nas ações coletivas, in Os processos coletivos nos países de civil law e common law, et. al., São Paulo, Revista dos Tribunais, 2008, p. 230). 
Houve, pouco tempo depois, leis setoriais que acenavam para a ampliação da tutela de interesses difusos no Brasil, são elas: Lei 6.938/1981 (que dispôs sobre a Política Nacional do Meio Ambiente e prevê no artigo 14, $\S 1^{\circ}$, a possibilidade de reparação pelos danos causados ao meio ambiente e a terceiros eventualmente afetados, a pedido do Ministério Público), Lei Complementar 40/1981 (Lei Orgânica do Ministério Público que incluiu no rol de atribuições do órgão a propositura de ação civil pública), a Lei 7.913/1989 (que previa a reparação dos investidores lesados no mercado de valores mobiliários).

Mas foi com a edição da Lei da Ação Civil Pública (Lei 7.347/85), a promulgação da Constituição Federal de 1988 e, finalmente, a entrada em vigor do Código de Defesa do Consumidor (Lei 8.078/90), que o microssistema de processos coletivos se completou, com a disciplina, inclusive, do tratamento coletivo merecido por interesses individuais de origem comum e com marcada homogeneidade, em prol da racionalização, da efetividade e da justiça nas decisões. Vale dizer que a Constituição Federal e o Código de Defesa do Consumidor cumpriram o papel fundamental de ampliar o alcance da Lei da Ação Civil Pública à tutela de qualquer interesse difuso ou coletivo ${ }^{29}$.

Ao lado dos direitos fundamentais de cunho individual, o constituinte erigiu a cláusula pétrea os direitos coletivos previstos no Título II da Carta Magna. Os direitos de cidadania ou de solidariedade (de terceira geração, como anotou Ada Pellegrini Grinover em passagem já mencionada) puderam, assim, ser articulados e concretizados lançando-se mão dos mecanismos processuais que compõem o microssistema brasileiro de processos coletivos.

\footnotetext{
${ }^{29}$ Embora a redação original da Lei 7.347/85 tenha sido restritiva, com apoio na insegurança jurídica que poderia advir de cláusulas abertas em textos legais, o veto presidencial, ao mesmo tempo em que extirpou as referências à proteção de "qualquer outro interesse difuso", anteviu que se tratava de inovação muito próxima de se inserir no ordenamento brasileiro, conforme Mensagem 359, de 24 de julho de 1985: "As razões de interesse público dizem respeito precipuamente a insegurança jurídica, em detrimento do bem comum, que decorre da amplíssima e imprecisa abrangência da expressão 'qualquer outro interesse difuso'. A amplitude de que se revestem as expressões ora vetadas do Projeto mostra-se, no presente momento de nossa experiência jurídica, inconveniente. É preciso que a questão dos interesses difusos, de inegável relevância social, mereça, ainda, maior reflexão e análise. Trata-se de instituto cujos pressupostos conceituais derivam de um processo de elaboração doutrinária, a recomendar, com a publicação desta Lei, discussão abrangente em todas as esferas de nossa vida social. É importante, neste momento, que, em relação à defesa e preservação dos direitos dos consumidores, assim como do patrimônio ecológico, natural e cultural do País, a tutela jurisdicional dos interesses difusos deixe de ser uma questão meramente acadêmica para converter-se em realidade jurídico-positiva, de verdadeiro alcance e conteúdo sociais. Eventuais hipóteses rebeldes à previsão do legislador, mas ditadas pela complexidade da vida social, merecerão a oportuna disciplinação legislativa".
} 
Além disso, o constituinte contemplou a posição das associações e dos sindicatos como entes legitimados para a tutela de interesses coletivos (artigos $5^{\circ}$, incisos LXX, alínea "b" ${ }^{30}$ e $8^{\circ}$, inciso III $^{31}$ ) e ratificou a legitimação do cidadão para a propositura da ação popular (artigo $5^{\circ}$, inciso LXXIII) ${ }^{32}$ com o incentivo da isenção de custas processuais e ônus sucumbenciais.

Por sua vez, o Código de Defesa do Consumidor (Lei 8.078, de 11 de setembro de 1990), em suas Disposições Finais, por meio do artigo 110, acrescentou o inciso IV ao artigo $1^{\circ}$ da Lei $\mathrm{n}^{\circ} 7.347 / 85$, incluindo no rol de bens tuteláveis mediante o instrumento da ação civil pública "qualquer outro interesse difuso ou coletivo".

Dado esse alto grau de desenvolvimento, o microssistema brasileiro de processos coletivos, pioneiro nos países de civil law, tem cumprido notável papel de influência sobre outros ordenamentos. A doutrina, inclusive, anima-se em afirmar que "o legislador brasileiro, na verdade, protagonizou, de modo muito mais profundo e mais rico do que nos demais países da civil law, a 'revolução' mencionada por Cappelletti e Garth"33 ou que o Brasil pode se orgulhar do completo e avançado sistema processual de tutela coletiva $^{34}$

E tamanha foi a receptividade do movimento brasileiro por um sistema processual próprio à tutela de interesses supraindividuais que nasceu, nas Jornadas de Direito Processual de 2002 em Montevidéu, e se desenvolveu a ideia de um Código Modelo de Processos Coletivos para a Ibero América, com o propósito de uniformizar e incentivar o tratamento dos interesses e direitos transindividuais nos países de cultura jurídica comum, que culminou no Código Modelo aprovado pelos membros do Instituto Ibero-Americano de Direito Processual em 2004.

\footnotetext{
30 “O mandado de segurança coletivo pode ser impetrado por: (...) organização sindical, entidade de classe ou associação regularmente constituída e em funcionamento há pelo menos um ano, em defesa dos interesses de seus membros ou associados".

31 "ao sindicato cabe a defesa dos direitos e interesses coletivos ou individuais da categoria, inclusive em questões judiciais ou administrativas".

32 “qualquer cidadão é parte legítima para propor ação popular que vise a anular ato lesivo ao patrimônio público ou de entidade de que o Estado participe, à moralidade administrativa, ao meio ambiente e ao patrimônio histórico e cultural, ficando o autor, salvo comprovada má-fé, isento de custas judiciais e do ônus da sucumbência".

${ }^{33}$ Cf. Teori Albino Zavascki, Processo coletivo - tutela de direitos coletivos e tutela coletiva de direitos, São Paulo, Revista dos Tribunais, 2006, p. 35.

${ }^{34}$ Barbosa Moreira, A ação civil pública e a língua portuguesa, in Ação Civil Pública - Lei 7.347/1985 - 15 anos (coord. Edis Milaré), 2a ed., São Paulo, Revista dos Tribunais, 2002, p. 345.
} 


\subsection{A otimização do acesso à justiça e os contornos do novo modelo de processo civil (public law litigation ou processo de interesse público)}

No contexto acima estudado, os instrumentos de proteção coletiva aos novos direitos permitiram a superação de obstáculos ilegítimos ao acesso à justiça, tais como, por exemplo, os altos custos psicológicos e financeiros da atuação individual, no caso dos direitos individuais homogêneos ${ }^{35}$. Tais obstáculos desestimulavam o ajuizamento de medidas que, na prática, promoveriam individualmente um ínfimo benefício jurídico ou econômico, mas que, quando tratadas coletivamente, se potencializavam.

Assim, inerente ao novo modelo de processo civil não é apenas a possibilidade de judicialização dos novos direitos, mas também e com grande relevância é a sua capacidade de desencorajar a conduta antijurídica do possível causador do dano na medida em que se, "apenas uma pequena parcela dos lesados levará ao Poder Judiciário a sua pretensão de indenização por danos por ela causados, e que, destes, uma parcela ainda inferior obterá a satisfação da mesma, com simples cálculos aritméticos saberá se vale a pena desobedecer determinada norma legal" ${ }^{36}$.

Evita-se a repetição e a perpetuação de práticas ilegais e lesivas com a consequência positiva de que, "tendo em vista que o próprio valor patrimonial da causa, que individualmente seria mínimo, passa a ser de grande relevância, chegando, por vezes, a importâncias astronômicas, o que, per se, já pode ser suficiente para ensejar o interesse de bons profissionais para a causa, além de recursos necessários para a propositura e colheita de provas" 37 .

Além disso, como bem apontou Aluísio Gonçalves de Castro Mendes, em países como o Brasil, em que a desinformação da população é um problema agudo mesmo na sociedade pós-industrial, os processos coletivos atenuam esse entrave ao acesso à Justiça na medida em que "o direito das pessoas menos esclarecidas juridicamente não

\footnotetext{
${ }^{35}$ Conforme já sustentava Mauro Cappelletti, para um autor de uma pequena causa (small claim) "uma demanda judicial é antieconômica", pois o "prêmio para qualquer indivíduo buscar essa correção [tutela jurisdicional] é pequeno demais para induzi-lo a tentar uma ação" (cf. Acesso à justiça, trad. Ellen Gracie Northfleet, Porto Alegre, Sérgio A. Fabris, 1988, p. 26 e seguintes).

${ }^{36}$ Cf. Luis Roberto Proença, Inquérito civil - atuação investigativa do Ministério Público a serviço da ampliação do acesso à Justiça, São Paulo, Revista dos Tribunais, 2001, pp. 24/25.

${ }^{37}$ Cf. Ações coletivas no Direito comparado e nacional, $2^{\mathrm{a}}$ ed., São Paulo, Revista dos Tribunais, 2010, p. 29. No mesmo sentido, veja-se Pedro da Silva Dinamarco, Ação civil pública, São Paulo, Saraiva, 2001, p. 45, tratando especificamente da conscientização daquele que, usualmente causava danos a interesses metaindividuais, acostumado com a impunidade, passou a temer a potencialidade de uma demanda judicial coletiva.
} 
ficará relegado ao abandono, porque poderá ser defendido por terceiro, legitimado extraordinariamente para a tutela transindividual"38. E ainda, Rodolfo de Camargo Mancuso observou que se "o homem é gregário", "os interesses individuais tendem, naturalmente, a aproximar-se de outros interesses individuais compatíveis, com vistas à proteção mútua e melhoria das possibilidades de sucesso para todos"39.

E é por essa razão que Elton Venturi afirma que a vindicação de interesses coletivos em juízo é instrumento de afirmação da cidadania, na medida em que "pode constituir um meio de dar adequada expressão a necessidades e aspirações que talvez não conseguissem fazer-se ouvir alhures" $"$.

Nessa nova realidade judiciária, percebe-se que o princípio da universalidade da jurisdição se abriu a novas causas ${ }^{41}$ e o escopo social do processo ganhou novo alcance, sendo possível dizer até que o Judiciário passou a enfrentar situações que põem em cheque as funções que desempenhava tradicionalmente na sociedade ${ }^{42}$. Tanto é assim que Norberto Bobbio ${ }^{43}$ se encorajou a dizer que as palavras de ordem das revoluções sociais e jurídicas do século XX são universalização e multiplicação.

${ }^{38}$ Cf. Ações coletivas cit., p. 30.

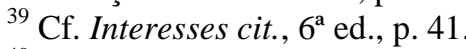

${ }^{40}$ Cf. Elton Venturi, Processo civil coletivo - A tutela jurisdicional dos direitos difusos, coletivos e individuais homogêneos no Brasil - Perspectivas de um Código Brasileiro de Processos Coletivos, São Paulo, Malheiros, 2007, pp. 108/109.

${ }^{41}$ Grinover, A ação civil pública refém cit., p. 237, Novas tendências cit., p. 98, com enfoque também à alteração do conceito de ação, "a qual se transforma em meio de participação política". Nas palavras de Cândido Rangel Dinamarco, a previsão de instrumento de tutela aos titulares de interesses transindividuais é uma das facetas do movimento de universalização da jurisdição, que almeja "reduzir ao mínimo inevitável os resíduos de conflitos não-jurisdicionalizáveis" (A Reforma do Código de Processo Civil, $2^{\mathrm{a}}$ ed., São Paulo, Malheiros, 1995, p. 19). Ou, ainda, na denominação empregada por Kazuo Watanabe a respeito dos Juizados Especiais de Pequenas Causas, existem meios tendentes à redução da "'litigiosidade contida', fenômeno extremamente perigoso para a estabilidade social, pois é um ingrediente a mais na 'panela de pressão' social, que já está demonstrando sinais de deteriorização do seu sistema de resistência". Um desses meios, ao lado dos juizados, são as ações coletivas que amenizam a mencionada "contenção" produzida por obstáculos à ordem jurídica justa (cf. Juizado Especial de Pequenas Causas, São Paulo, Revista dos Tribunais, 1985, pp. 1/2). A propósito, definindo com precisão o que se entendeu por litigiosidade contida, Vigliar assevera que se trata "do sentimento compartilhado não somente por aqueles detentores de situações jurídicas que, do pontode-vista puramente econômico (custo versus benefício), não os encorajava ao enfrentamento de um processo realizado segundo as regras tradicionais do Código de Processo Civil, porque os procedimentos (mesmo aquele que se denominava sumaríssimo) pressupunham sempre investimentos (no mínimo de tempo e quase sempre de recursos financeiros) desproporcionais ao prejuízo suportado mas também (e principalmente) pelos menos afortunados que, sem nenhuma carga de preconceito, nas suas relações jurídicas diárias, sujeitam-se muito mais a conflitos menores" (cf. Tutela jurisdicional coletiva cit., p. 21).

${ }^{42}$ Kazuo Watanabe observa que "na solução dos conflitos que nascem das relações geradas pela economia de massa, quando essencialmente de natureza coletiva, o processo deve operar também como instrumento de mediação dos conflitos sociais neles envolvidos e não apenas como instrumento de solução de lides" (cf. Código Brasileiro de Defesa do Consumidor comentado pelos autores do anteprojeto, $9^{\mathrm{a}}$ ed., Rio de Janeiro, Forense Universitária, 2007, p. 797).

${ }^{43}$ Cf. A era de direitos, p. 67, apud Lenza, Teoria geral cit., $2^{\text {a }}$ ed., p. 29. 
Segundo Eurico Ferraresi ${ }^{44}$, os fenômenos da globalização e da sociedade de massa aproximaram o processo dos direitos fundamentais na medida em que a proteção aos direitos titularizados por uma coletividade foram elevados a cláusulas constitucionais em ordenamentos jurídicos de diversas nações. Nesse contexto, mais do que instrumento de efetivação de direitos, o processo equivale a um instrumento de participação política na gestão da coisa pública, ocupando papel fundamental nos Estados democráticos contemporâneos.

Por isso, como já mencionado, salutar também “uma alteração do padrão tradicional de funcionamento das normas de processo implicadas nesses novos casos" com a "emergência de um novo modelo processual, construído a partir da necessidade de oferecer respostas a um tipo de litígio diferenciado daqueles tradicionalmente tratados no processo civil" e "baseado em premissas funcionais e estruturais diversas" 45 .

Afinal, já se disse também que não bastava incorporar ao direito processual os institutos da chamada "segunda onda renovatória". Os ideais da "terceira onda renovatória", de transformar o processo em mecanismo ajustado à configuração dos novos conflitos, tiveram premente importância no cenário estudado neste trabalho. Por isso, Mauro Cappelletti qualificou como audaciosas ${ }^{46}$ as novas construções jurídicas adaptadas à tutela dos interesses metaindividuais e indaga "se não seria muito mais escandaloso ainda negar acesso à justiça aos novos interesses coletivos"?

A despeito da resistência daqueles que enxergavam na "revolução" uma transgressão a postulados fundamentais do processo civil (tais como as garantias do due process of law), significativas transformações foram e ainda vem sendo desenvolvidas pelos ordenamentos que se propuseram a atribuir efetiva tutela aos direitos sociais.

Ficou nítido para os processualistas contemporâneos que a insuficiência dos institutos e princípios fundamentais do processo individualista impunha não o seu abandono, mas a sua superação, com a introdução de um novo garantismo, o "garantismo social" ou "coletivo" a fim de concretizar a promessa constitucional de efetivo acesso à justiça ou à ordem jurídica justa.

\footnotetext{
${ }^{44}$ Ação popular, ação civil pública e mandado de segurança coletivo - instrumentos processuais coletivos, Rio de Janeiro, Forense, 2009, pp. 3/4.

${ }^{45}$ Cf. Salles, Processo civil de interesse público cit., pp. 61/63.

${ }^{46}$ Cf. Cappelletti, Formações cit., pp. 153/154.
} 
Vittorio Denti sustentou que o novo garantismo "risponde ad una esigenza di uguaglianza reale o sostanziale tra le parti stesse" ${ }^{, 47}$. Por sua vez, Vigoriti enfatizou que: "In fondo, la class action è uno strumento forgiato per la tutela di situazioni individuali a dimensione collettiva, situazioni che, isolatamente considerate, non avrebbero accesso alla giustizia, per cui davvero l'imposizione di una pesante bardatura garantistica servirebbe solo a comprometterne le aspirazioni di tutela" ${ }^{48}$, enfatizando, portanto, a faceta democrática dos instrumentos processuais forjados à tutela de interesses coletivos lato sensu.

Sob a égide desse novo garantismo, entre 1976 e 1977, Cappelletti ${ }^{49}$ visualizou no novo modelo características diferenciadoras que significaram uma verdadeira revolução nos temas de poderes do juiz e das garantias processuais das partes (notadamente o conceito de coisa julgada e o princípio do contraditório), com destaque para o seguinte: a) criação de instituições de organismos públicos altamente especializados, b) extensão da legitimidade de agir a sujeitos privados não pessoalmente prejudicados, que antes de uma relação jurídica com o objeto deduzido em juízo, possuíam com este uma conexão ideológica, e que fossem bons paladinos ${ }^{50}$ do interesse perseguido; e c) extensão dos poderes do juiz.

De fato, dos estudiosos italianos extraem-se considerações de grande relevo a respeito das novas formações sociais e da adequação do modelo processual para a sua satisfação. Contudo dada a falta de desenvolvimento legislativo do sistema italiano acerca da matéria, é comum mencionar que a grande herança dos italianos nos estudos das décadas de 1960 e 1970 é teórica.

Por sua vez, em razão da consolidada e bem sucedida experiência das class actions $^{51}$, nas investigações norte-americanas foram assimilados e definidos importantes

\footnotetext{
${ }^{47}$ Cf. Il ruolo del giudice nel processo civile tra vecchio e nuovo garantismo, in Rivista Trimestrale di Diritto e Procedura Civile, Milão, v. 38, setembro de 1984, p. 726.

${ }^{48}$ Cf. Interessi cit., p. 276.

${ }^{49}$ Cappelletti, Formações cit., p. 141.

${ }^{50}$ Cappelletti, Appunti sulla tutela giurisdizionale di interessi collettivi o diffusi, in Le azioni a tutela di interessi collettivi: atti del convegno di Studio, Pádua, Cedam, 1976, pp. 200/201.

${ }^{51}$ Esclarecedora definição da class action sob a égide do direito norte-americano é de Thomas A. Dickerson: "is an equitable concept which originated as an exception to the general rule in equity that all persons (however numerous) materially interested in the subject matter of a suit were to be made parties to it. The class suit was an invention of equity to allow a suit to proceed when the parties interested in the subject were so numerous that is would have been impracticable to join them without long delays and inconveniences which would obstruct the purposes of justice. Under these conditions representatives of a class conduct litigation on behalf of themselves and all others similarly situated and the judgment binds all members" (cf. Class action: the Law of 50 States, apud Pedro da Silva Dinamarco, Ação civil pública cit., p. 15).
} 
traços diferenciadores do novo modelo de processo. Em 1976, Abram Chayes ${ }^{52}$ publicou estudo elucidativo sobre as características marcantes da public law litigation. Poucos anos depois, precisamente em 1982, Owen Fiss tratou em detalhes das características do novo modelo de adjudicação forjado à solução dos conflitos que transcendem à órbita do indivíduo singular.

Fiss identificou nessa nova forma de adjudicação a consciência de que "a principal ameaça aos valores constitucionais norte-americanos não é proveniente de indivíduos, mas das operações das organizações de grande porte, as burocracias do Estado moderno" ${ }^{33}$, confirmando que, naturalmente, a massificação das relações sociais produziu transformações também nos ordenamentos jurídicos de common law nos anos 60 e 70.

Nesse contexto de análise, a primeira nota característica do novo modelo de litigância decorre da configuração fragmentada do próprio interesse em jogo. Sendo dispersos e concorrentes os interesses em conflito, a estrutura de partes do processo de cunho coletivo é amorfa e não mais simplesmente bipolarizada como ocorria no modelo tradicional.

Segundo Fiss, "o antagonismo não é binário" ${ }^{54}$ na nova modalidade de adjudicação, pois os papéis de partes no processo não são ocupados pelos titulares do direito discutido em juízo, havendo ainda a intervenção de auxiliares que não são nem titulares do direito nem representantes dos titulares. Afinal, uma política pública - que é no mais das vezes o objeto perseguido pelo autor de uma ação coletiva - tem referência plurilateral ${ }^{55}$ e "o homem não é tomado em sua acepção singular, e sim em dimensão coletiva, vale dizer, enquanto integrante de uma coletividade mais ou menos vasta"56. Daí falar-se na molecularização do litígio ${ }^{57}$, em contraposição à ideia de atomização.

\footnotetext{
${ }^{52}$ Abram Chayes, The role of the judge in public law litigation, in Harvard Law Review, vol. 89, maio de 1976, pp. 1281/1315.

53 “A adjudicação é o processo pelo qual são dados significado e expressão concretos aos valores incorporados em um texto jurídico dotado de grande autoridade, tal como a Constituição" (cf. Owen Fiss, Um novo processo civil: estudos norte-americanos sobre jurisdição, constituição e sociedade, São Paulo, Revista dos Tribunais, 2004, pp. 105/106).

${ }^{54}$ Cf. Fiss, cit., p. 109.

${ }^{55}$ Lopes, Direitos sociais cit., p. 128.

${ }^{56} \mathrm{Cf}$. Mancuso, Interesses cit., p. 274

${ }^{57}$ Kazuo Watanabe, Demandas coletivas e os problemas emergentes da práxis forense, Revista de Processo n. 67, ano 17, julho a setembro de 1992, p. 19.
} 
Disso decorreu a reorganização da sociedade civil ${ }^{58}$, emergindo grupos e associações, chamados de corpos intermediários ${ }^{59}$, representantes ideológicos ${ }^{60}$ ou, ainda, "centri di imputazione" ${ }^{\prime \prime 1}$, portadores e expoentes de interesses coletivos, donde se nota a necessidade de adaptar o conceito de legitimidade ${ }^{62}$.

A partir daí, outras questões relevantes são debatidas (algumas mais políticas do que jurídicas), tais como: a falta de legitimidade de certas figuras da sociedade civil (v.g., o cidadão singular que, no direito norte-americano, detém legitimidade para propor uma class action, desde que faça parte do grupo ou coletividade tutelada), a atribuição de legitimidade a entes públicos desprovidos de pertinência temática ao bem jurídico coletivo (v.g. Ministério Público, Defensoria Pública), a conveniência de se controlar, ope iudicis, a adequação da representatividade do ente legitimado, a adequação da notificação endereçada aos membros ausentes do grupo ou ainda a quem cabe o ônus financeiro de promover uma notificação adequada dos ausentes (no caso das class actions norte-americanas).

Consequência direta dessa primeira característica das ações coletivas é que os reflexos da decisão proferida pelo juiz de um processo coletivo não ficam confinados à esfera jurídica das partes, que não são detentoras do direito subjetivo. Por essa razão, para o processo de índole coletiva, foi necessário repensar o conceito de coisa julgada, adequando os seus limites subjetivos a um objeto litigioso que diz respeito a membros, às vezes indetermináveis, de dada coletividade.

\footnotetext{
${ }^{58}$ Grinover, A ação civil pública refém cit., p. 237. Uma reorganização que visa, quase integralmente, à atuação mais cuidadosa e superior qualitativamente daquela exercida individualmente: "Certos interesses são mais bem defendidos em juízo por pessoas jurídicas que, dispondo de maiores recursos e gozando dos benefícios da organização, podem enfrentar em melhores condições adversários econômica ou politicamente poderosos" (cf. Barbosa Moreira, Tendências contemporâneas do direito processual civil, in Temas de Direito Processual Civil - Terceira Série, São Paulo, Saraiva, 1984, p. 9).

${ }^{59}$ Mancuso, Interesses cit., p. 63.

${ }^{60}$ Porta-voz qualificado dos interesses transindividuais, nas palavras de Cappelletti (Formações cit., p. 151).

${ }^{61}$ Cf. Adolfo di Majo, La tutela civile dei diritti, $2^{\mathrm{a}}$ ed., vol. III, Milão, Giuffrè, 1993, p. 35.

${ }^{62}$ A relevância jurídica de tais corpos intermediários foi lembrada por Alessandro Pizzorusso, para quem houve uma reestruturação do ordenamento com base no "pluralismo istituzionale, cioè ammetendosi che la comunità nazionale non si compone soltanto di individui - come sosteneva la dottrina politica liberale - ma comprende altresi una pluralità di aggregazioni sociali diverse (limitate dal punto de vista territoriale o da quella personale), delle quali quella che corrisponde allo Stato é verosimilmente la più importante, ma sicuramente non l'unica che abbia rilevanza per il diritto", de modo que se atribui caráter pluralista ao Estado que prevê a tutela de agregações sociais, “per mettere in rilievo l'esistenza di una pluralità di comunità rilevanti per il diritto, comprese nell'ambito della più ampia comunità nazionale, ma suscetibili di essere considerate anche in contraposizione ad essa" (cf. Alessandro Pizzorusso, Partecipazione popolare, in Participação e processo cit., pp. 29 e 36).
} 
Ao lado disso, no processo que envolve interesses transindividuais, a atuação do órgão jurisdicional não se esgota com a prolação da sentença. O juiz, dotado de intenso e verdadeiro case management, assume papel de administrador das políticas públicas promovidas em prol dos interesses coletivos, porque a medida judicial deverá durar pelo menos enquanto dure a realidade social que ela tenta modificar ${ }^{63}$.

E com tal propósito, invocando as palavras de Owen Fiss, “a corte está capacitada para pensar em termos inteiramente prospectivos" ${ }^{64}$, cuja complexidade e sofisticação exige que o juiz assuma um papel ativo, abandonando a posição de mero árbitro passivo e inerte. A nova postura que o magistrado deve assumir é ponto sensível da terceira onda renovatória do processo civil e influi, segundo Pedro Lenza ${ }^{65}$, inclusive na justiça das decisões.

Ainda, Chayes asseverou que é inerente ao modelo de public law litigation que o seu desfecho seja, tanto quanto possível, resultado de negociação das partes para que a solução seja aceita e observada em sua máxima intensidade. E nesse contexto, "the judge will often find himself a personal participant in the negotiations on relief" ${ }^{36}$, prestigiandose uma solução negociada - ainda que na esfera judicial - em detrimento da solução adjudicada autoritariamente pelo juiz.

Tal noção de solução negociada se aproxima do que o Kazuo Watanabe denominou de "cultura da pacificação" que deve superar a chamada "cultura da sentença", privilegiando o escopo maior da efetiva pacificação dos conflitos ${ }^{67}$. Embora resistente na realidade brasileira por conta de uma arraigada tradição contenciosa, a cultura da pacificação, notadamente no âmbito da tutela dos consumidores, vem ganhando força no cenário brasileiro ${ }^{68}$.

São essas, assim, as características essenciais e os papéis desempenhados pelo processo coletivo.

\footnotetext{
${ }^{63}$ Fiss, cit., p. 113.

${ }^{64}$ Op. cit.., p. 110.

${ }^{65}$ Teoria geral cit., $2^{\mathrm{a}}$ ed., pp. 147/148.

${ }^{66} \mathrm{Cf}$. The role of the judge cit., p. 1300.

${ }^{67} \mathrm{Cf}$. Cultura da sentença e cultura da pacificação, in Estudos em homenagem à Professora Ada Pellegrini Grinover, São Paulo, DPJ, 2005, pp. 684/686.

${ }^{68}$ Exemplo recente desse movimento poderá ser visto, provavelmente, no que vier a ser o projeto de reforma do Código Brasileiro de Defesa do Consumidor, em especial no propósito de fortalecimento dos Procons "a fim de reduzir e litigiosidade judicial", como afirmou Herman Benjamin (Disponível em <http://www.stj.jus.br/portal_stj/publicacao/engine.wsp?tmp.area=398\&tmp.texto=100069>, acesso em 20/12/2010).
} 


\subsection{Um ramo autônomo do direito processual que tende à afirmação da cidadania e da democracia}

Carlos Alberto de Salles, ao admitir a existência de um novo tipo de litigância (processo civil de interesse público), não nega a necessidade de um tratamento diferenciado pelo direito processual e fala de um "novo modelo jurisdicional" denomina de processo civil de interesse público.

À luz do exposto até aqui, parece-nos que a criação de institutos e mecanismos próprios para o trato judicial de interesses transindividuais acenam para um ramo autônomo do direito processual civil que merece exame e cuidado diferenciados, tanto para otimizar o ingresso dessas causas ao Judiciário, quanto para melhor gerenciá-las, sob pena de se fracassar na busca pela efetividade do microssistema e pela superação dos obstáculos ao acesso à justiça.

Conforme leciona Kazuo Watanabe, da correta aplicação do microssistema de processos coletivos decorre a efetividade do instrumento, a capacidade de tutelar adequadamente os direitos das partes e a possibilidade de "resgate da imagem, hoje muito abalada, do nosso Judiciário"70. Para Fredie Didier Jr. e Hermes Zaneti Jr., o aumento da credibilidade do Poder Judiciário é verdadeiro fundamento político das ações coletivas ${ }^{71}$.

Por isso, mais do que enxergar no processo coletivo um objeto de estudo dotado de singularidades curiosas, o processualista que se debruça sobre o assunto se incumbe de repensar o instrumento processual, com vista ao resultado efetivo da tutela jurisdicional à luz dos escopos da jurisdição. Afinal, no contexto da sociedade massificada e globalizada, diante de conflitos cada mais sofisticados, os desafios que se apresentam impõem uma releitura até mesmo do significado de pacificação social ${ }^{72}$.

\footnotetext{
${ }^{69}$ Cf. Processo civil de interesse público cit., pp. 47/50. Mancuso, por sua vez, descarta a hipótese de uma revolução no processo civil e sustenta que "o melhor caminho a seguir seja o que conjugue a adaptação dos recursos existentes na ciência processual com a criação (onde a adaptação não se afigure possível ou eficaz) dos institutos e categorias necessários à tutela desses interesses metaindividuais" (Interesses cit., p. 278).

${ }^{70}$ Cf. Demandas coletivas cit., p. 23.

${ }^{71}$ Curso cit., p. 34.

72 "é preciso, antes de mais nada, que o processualista tenha a coragem intelectual de admitir que hoje afloram no processo situações diversas daquelas que constituíam o suporte dos institutos tradicionais. A tradição doutrinária não pode significar um obstáculo para repensar institutos, que hão de ser moldados às novas situações" (cf. Grinover, Novas tendências na tutela jurisdicional dos interesses difusos, in O processo em sua unidade cit., p. 104), preconizando a autora uma análise funcional do sistema processual para a formulação de um processo idôneo à tutela das novas situações que se dispõe a enfrentar.
} 
Mais ainda do que uma postura crítica, a efetividade do sistema processual coletiva depende do comportamento dos membros em geral da comunidade. Conforme afirma José Carlos Barbosa Moreira, "Não é a carência de meios processuais que responde pela subsistência, entre nós, de uma situação ainda largamente insatisfatória" ${ }^{\text {"73 }}$ no que diz respeito à tutela dos interesses coletivos.

Em uma perspectiva mais ampla, com base dos relatórios nacionais e transnacionais, apresentados no âmbito do XIII Congresso Mundial da Associação Internacional de Direito Processual, Ada Pellegrini chega a afirmar que há uma verdadeira tendência de "destinar aos processos coletivos estrutura própria, revisitando os institutos do direito processual clássico, para adaptá-los à efetiva tutela dos direitos transindividuais"74.

Nos dizeres de Elton Venturi ${ }^{75}$, é por meio da "justiça social" que se concretizam a cidadania e a democracia, objetivos que antes sequer eram perseguidos pelos operadores do processo. Isso porque, enquanto existirem direitos violados, de tutela jurisdicional sonegada pelo ordenamento, não se realizará plenamente a cidadania. Dessa forma, o autor alça o adequado funcionamento de um sistema de tutela jurisdicional coletiva à condição de existência da democracia, diante da busca pela superação dos obstáculos econômicos, culturais, jurídicos e políticos ao pleno acesso à justiça.

Na mesma linha, segundo Aluísio Gonçalves de Castro Mendes, o equacionamento das modificações sociais, econômicas, políticas e culturais permite o "pleno funcionamento do Estado Democrático de Direito"76. Daí a necessidade de correlacionar e adaptar o processo civil ao tipo de litígio para que o processo seja "bem

\footnotetext{
${ }^{73}$ Cf. A ação civil pública e a língua portuguesa, in Ação Civil Pública - Lei 7.347/1985 - 15 anos (coord. Edis Milaré), $2^{a}$ ed., São Paulo, Revista dos Tribunais, 2002, pp. 345/349. O autor, a título de exemplo e para reforçar a ideia, não mediu esforços para sugerir o cabimento de ação civil pública, por ofensa ao art. 13, da Constituição Federal, em situações em que certos estrangeirismos afetam desproporcionalmente o quotidiano da comunidade, inserindo-se, para tanto, a língua portuguesa no âmbito de proteção do patrimônio cultural brasileiro.

${ }^{74}$ Cf. Novas tendências em matéria de legitimação e coisa julgada nas ações coletivas cit., p 236.

${ }^{75}$ Processo civil coletivo cit., p. 111, e Comentários ao Código Modelo de Processos Coletivos - um diálogo ibero-americano (coord. Antonio Gidi e Eduardo Ferrer Mac-Gregor), Salvador, JusPodivm, 2009, p. 20. Ainda sobre o tema, na linha de afirmação da cidadania e da democracia mediante a criação de instrumentos de tutela de interesses coletivos, confiram-se: Grinover, Significado social cit., p. 10, Pedro da Silva Dinamarco, Ação civil pública cit., p. 42, com referências à doutrina de Enrique Vescovi e Vittorio Denti.

${ }^{76}$ Cf. Ações coletivas cit., p. 27. Vide também: Barbosa Moreira, Ações coletivas na Constituição Federal de 1988 cit., pp. 198/199; Cappelletti, O acesso à justiça e a função do jurista em nossa época, São Paulo, Revista de Processo, n. 61, janeiro a março de 1991, p. 147.
} 
aderente ao direito material" 77 de forma a permitir o "acesso à ordem jurídica justa". Somente assim se concretizará o ideário da escola instrumentalista ${ }^{78}$ desenvolvido pela contemporânea doutrina processual.

De fato, o despertar para a imprescindível tutela dos direitos transindividuais, além da já mencionada reconfiguração do poder jurisdicional, promove também a participação dos cidadãos nas escolhas políticas do Estado, o que fortalece o ideal democrático e promove a justiça social ${ }^{79}$.

${ }^{77}$ Kazuo Watanabe, Da cognição no processo civil, São Paulo, Revista dos Tribunais, 1987, p. 17. Também nesse sentido, na doutrina italiana, veja-se: Giuseppe Tarzia, in Participação e processo cit., p. 53.

${ }^{78} \mathrm{~A}$ respeito do desenvolvimento da ciência processual, desde a chamada fase sincretista até o engajamento da doutrina processual atual ao instrumentalismo, confiram-se: Cândido Rangel Dinamarco, Instituições de Direito Processual Civil, vol. I, $5^{\text {a }}$ ed., São Paulo, Malheiros, 2005, pp. 286/301; José Roberto dos Santos Bedaque, Direito e processo, $5^{\text {a }}$ ed., São Paulo, Malheiros, 2009, pp. 28/30 e Efetividade do Processo e Técnica Processual, $2^{\mathrm{a}}$ ed., São Paulo, Malheiros, 2007, pp. 19/21; José Carlos Barbosa Moreira, Notas sobre o problema da efetividade do processo, in Temas de Direito Processual - Terceira Série, São Paulo, Saraiva, 1984, pp. 27/42.

${ }^{79}$ Conforme enfatizou José Rogério Cruz e Tucci, com referência às lições de Nicolò Trocker, como dito, um dos expoentes italianos nos estudos dos direitos supraindividuais a partir do Congresso de Pavia, "as ações de grupo, 'muito mais do que os atuais instrumentos de intervenção ad coadjuvandum ou de litisconsórcio necessário, reclamam a atenção do juiz para um maior segmento da realidade, e, oferecendo-lhe uma visão 'global' dos conflitos, possibilitam-lhe também ditar um regramento de interesses mais exauriente. Em suma, aquelas não só reforçam a legitimação democrática dos pronunciamentos judiciais, mas e é o que mais interessa - propiciam avizinhar o processo civil de uma maior justiça social"” (cf. Código do consumidor e processo civil, in Revista dos Tribunais, v. 80, n. 671, p. 34). 


\section{Interesses envolvidos em ações coletivas ${ }^{80}$ na perspectiva do direito brasileiro}

No decorrer do estudo das transformações do processo à luz das novas formações da sociedade de massa, mencionamos que passaram a ser objeto de tutela jurisdicional interesses que fugiam do vetor que ligava o interesse ao direito subjetivo e enaltecia, perante a comunidade jurídica, apenas a figura do individuo.

De fato, o modelo tradicional, como visto, pressupunha a satisfação de um interesse somente se constatada a presença de norma que conferisse um direito subjetivo ao seu pretenso e definido titular. No máximo, o termo "coletivo" era empregado na acepção ampla para designar o conflito nas hipóteses que envolviam o interesse de uma pluralidade de sujeitos ${ }^{81}$. Nesse contexto, o sistema processual cuidava dos instrumentos aptos a “atender à prestação da tutela jurisdicional em casos de lesões a direitos subjetivos individuais, mediante demandas promovidas pelo próprio lesado" ${ }^{\prime 2}$.

Daí porque é de tamanha expressividade nesse cenário a regra presente no artigo $6^{\circ}$ do atual Código de Processo Civil ${ }^{83}$, no sentido de que "Ninguém poderá pleitear,

\footnotetext{
${ }^{80}$ Empregaremos a expressão "ação coletiva", para designar a demanda em que se deduz pretensão de tutela a direitos transindividuais, a exemplo do Código Modelo de Processos Coletivos para os países IberoAmericanos que reuniu na expressão todas as possíveis denominações já lançadas para esse papel: “Art. $1^{\circ}$. Cabimento da ação coletiva - A ação coletiva será exercida para a tutela de: I - interesses ou direitos difusos, assim entendidos os transindividuais, de natureza indivisível, de que seja titular um grupo, categoria ou classe de pessoas ligadas por circunstâncias de fato ou vinculadas, entre si ou com a parte contrária, por uma relação jurídica base; II - interesses ou direitos individuais homogêneos, assim entendido o conjunto de direitos subjetivos individuais, decorrentes de origem comum, de que sejam titulares os membros de um grupo, categoria ou classe". Conforme também observa Rodolfo de Camargo Mancuso, "uma ação recebe a qualificação de 'coletiva' quando através dela se pretende alcançar uma dimensão metaindividual, (...) quando algum nível do universo coletivo será atingido no momento em que transitar em julgado a decisão que a acolhe, espraiando assim seus efeitos, seja na notável dimensão dos interesses difusos, ou ao interior de certos corpos intercalares onde se aglutinam interesses coletivos, ou ainda no âmbito de certos grupos ocasionalmente constituídos em função de uma origem comum, como se dá com os chamados 'individuais homogêneos" (cf. Ação Popular, 6a ed., São Paulo, Revista dos Tribunais, 2008, p. 42). Não se ignora, no entanto, a ideia de que a ação - concebida como o direito de postular ao Estado uma solução diante de determinada crise jurídica - independa de adjetivação porque é marcada por nota de generalidade (cf. Yarshell, Tutela jurisdicional, São Paulo, Atlas, 1999, pp. 58 e seguintes, e Vigliar, Interesses individuais homogêneos e seus aspectos polêmicos cit., pp. 60/62).

${ }^{81}$ Assim, por exemplo, "o interesse de todos os condôminos em que a solidez e a segurança do imóvel em condomínio não sejam atingidas por obra em terreno vizinho; ou o de todos os acionistas em que a companhia seja ressarcida do prejuízo acaso resultante de ato ilegal do administrador" (cf. Barbosa Moreira, Tutela jurisdicional dos interesses coletivos ou difusos, in Temas de Direito Processual Civil - Terceira Série, São Paulo, Saraiva, 1984, p. 194) ou, ainda ilustrando, a situação na qual há acionistas de uma companhia interessados em anulação de dado deliberação assemblear.

${ }^{82}$ Cf. Zavascki, Processo coletivo cit., $4^{\mathrm{a}}$ ed., p. 17.

${ }^{83}$ Regra semelhante é encontrada no art. 81 do Codice di Procedura Civile italiano ("Fuori dei casi espressamente previsti dalla legge, nessuno puo' far valere nel processo in nome proprio un diritto altrui'), no art. $26^{\circ}, n^{\circ} 3$, do Código de Processo Civil português ("Na falta de indicação da lei em contrário, são considerados titulares do interesse relevante para o efeito da legitimidade os sujeitos da relação controvertida, tal como é configurada pelo autor"), no art. 10 da Ley di Enjuiciamiento Civil espanhola ("Serán considerados partes legítimas quienes comparezcan y actúen en juicio como titulares de la relación jurídica u
} 
em nome próprio, direito alheio, salvo quando autorizado por lei”, evidenciando que, para o legislador preocupado na atuação do direito objetivo para a preservação de direitos subjetivamente violados, apenas por exceção é que determinado sujeito estaria em juízo para a defesa de interesses alheios.

Por força dessa regra da essência do sistema processual de cunho individualista, o comando emanado do processo envolvendo um litígio bipolarizado (em que de um lado se colocava o interesse de um titular predeterminado e de outro um interesse contraposto), a autoridade da coisa julgada se mantinha enclausurada na esfera jurídica das partes ${ }^{84}$.

O interesse jurídico, nessa ótica tradicional, diferencia e qualifica a posição do sujeito a respeito de um bem jurídico, suscetível de apropriação ou de fruição individual, ensejando a existência de um direito subjetivo ${ }^{85}$.

E aqui, adotaremos a concepção de Kazuo Watanabe de que: "os termos 'interesses ‘ e 'direitos' foram utilizados como sinônimos, certo é que, a partir do momento em que passam a ser amparados pelo direito, os 'interesses' assumem o mesmo 'status' de 'direito', desaparecendo qualquer razão prática e mesmo teórica, para a busca de uma diferenciação ontológica entre eles" ${ }^{\$ 6}$. Em realidade, essa diferença teórica só fazia sentido na ótica liberal individualista do processo.

objeto litigioso. Se exceptúan los casos en que por ley se atribuya legitimación a persona distinta del titular") e em outros muitos diplomas processuais de ordenamentos de raízes romano-germânicas.

84 "Os pontos mais expressivos desse individualismo na tutela jurisdicional eram representados pela legitimidade necessariamente individual $\left(\mathrm{CPC}\right.$, art. $6^{\circ}$ ), pelos efeitos diretos da sentença invariavelmente limitados às partes do processo e pela rigorosa limitação subjetiva da autoridade da coisa julgada (art. 472). Sobre esse tripé apóia-se a tutela jurisdicional individual em todos os ordenamentos a que a nossa tradição cultural se filia" (cf. Dinamarco, A reforma do Código de Processo Civil cit., $5^{\mathrm{a}}$ ed., p. 28).

${ }^{85}$ Majo, La tutela civile dei diritti cit., p. 32.

${ }^{86}$ Cf. Watanabe, Código Brasileiro de Defesa do Consumidor cit., 2000, p. 718; Zavascki, Comentários ao Código Modelo de Processos Coletivos cit., p. 277. E também na mesma linha a sempre pertinente lembrança de Barbosa Moreira de que: "inexiste princípio a priori segundo o qual toda situação jurídica subjetiva que se candidate à tutela estatal por meio do processo deva obrigatoriamente exibir carta de cidadania entre os direitos, no sentido rigoroso da palavra" (cf. A ação popular no direito brasileiro como instrumento de tutela jurisdicional dos chamados "interesses difusos", in Temas de Direito Processual - Primeira Série, $2^{a}$ ed., São Paulo, Saraiva, 1988, p. 114). Ainda sobre o tema, confiram-se: Vigliar, Tutela jurisdicional coletiva, $3^{\mathrm{a}}$ ed., São Paulo, Atlas, 2001, pp. 59/60; Venturi, Comentários ao Código Modelo de Processos Coletivos cit., p. 29; Antônio Herman V. Benjamin, A insurreição da aldeia global contra o processo civil clássico, in Ação civil pública - Lei 7.347/85 - Reminiscências e reflexões sobre dez anos de aplicação (coord. Édis Milaré), São Paulo, Revista dos Tribunais, 1995, p. 83; Lenza, Teoria geral cit., $3^{\mathrm{a}}$ ed., pp. 54/55, para quem direito e interesse são a mesma "alma", com destaque para a ressalva feita pelo autor de que a inexistência de interesse prático na construção teórica que os diferencia se dá, no direito brasileiro, por conta da unitariedade da jurisdição; por sua vez, no direito italiano, lembrando a referência feita por Fazzalari (La giustizia civile in Italia, in La giustizia civile nei paesi comunitari, coord. Elio Fazzalari, Padova, Cedam, 1996, vol. II, pp. 73/74), o autor anota a importância de diferenciar "direito" de "interesse", a fim de definir a competência da jurisdição civil, perante a qual são deduzidos pedidos fundados em direitos subjetivos, e da jurisdição 
Mas, como desenvolvido nas linhas precedentes, os interesses desvendados pela sociedade pós-industrial não se adequavam a esse molde e não encontravam amparo nos mecanismos processuais de tutela de direitos subjetivos (interesses privados) nem de efetivação de poderes de entes públicos (interesses públicos).

Convencionou-se denominar esses novos interesses, evidenciados pela sociedade de massa, de interesses coletivos lato sensu, transindividuais, metaindividuais ou, ainda, supraindividuais.

Para conceituar as modalidades de interesses envolvidos nas ações coletivas, o legislador adotou no Código de Defesa do Consumidor classificação tripartida, que já vinha sendo desenvolvida pela doutrina ${ }^{87}$, embora não isenta de críticas $^{88}$.

A par das críticas à tentativa do legislador de lançar mão de conceitos a respeito de categorias ou institutos jurídicos, o que se deve lembrar é sempre o alerta de que o conceitualismo exacerbado não pode inviabilizar o processamento de uma ação coletiva. Ou seja, o que mais importa é a verificação, in concreto, da procedibilidade da

administrativa, em que se deduzem pretensões baseadas em interesses legítimos perante a administração pública. Vale a nota ao empenho de Antonio Gidi, apoiando-se na lição de Calmon de Passos, em rechaçar a suposição da doutrina clássica de que apenas um indivíduo pode ser titular de direito e, assim, adota amplamente as expressões "direitos difusos", "direitos coletivos" e "direitos individuais homogêneos" (Gidi, Coisa julgada e litispendência em ações coletivas, São Paulo, Saraiva, 1995, pp. 17/18).

${ }^{87}$ Barbosa Moreira, A ação popular no direito brasileiro como instrumento de tutela cit., pp. 110/114; Mancuso, Interesses difusos: conceito e colocação no quadro geral dos 'interesses', São Paulo, Revista dos Tribunais, Revista de Processo, n. 55, julho a setembro de 1989, pp. 165/179. Elogiando a opção do legislador por essa classificação tripartida: Vigliar, Interesses individuais homogêneos e seus aspectos polêmicos cit., p. 20.

${ }^{88}$ Gidi, Rumo a um Código de Processo Civil Coletivo: a codificação das ações coletivas do Brasil, Rio de Janeiro, Forense, 2008, pp. 201/202, em que o autor afirma tratar-se de "teorização artificial e abstrata realizada pela doutrina italiana, quando na década de setenta e oitenta, tentava compreender o fenômeno inédito das demandas coletivas norte-americanas", com a conclusão de que "são categorias absolutamente inúteis para a operacionalidade dos processos coletivos e da tutela dos direitos de grupo". Isso sem contar as reiteradas críticas da doutrina processual à prática do legislador nacional de elaborar conceitos em textos de lei: "Esses fatos demonstram a fragilidade dos conceitos postos em legislações e confirmam não ser de boa governança legislativa a fixação de amarras conceituais à maioria dos institutos jurídicos. Mesmo porque a eficácia normativa se perpetua no tempo quanto mais aberto for seu conteúdo. Os conceitos, quando positivados, tendem a se distorcer com o tempo, por força da dinâmica das relações jurídicas e do inescapável confronto com o caso concreto, o que expõe, realisticamente, as suas inconsistências e imperfeições" (cf. Pedro Batista Martins, A arbitragem e o mito da sentença parcial, in Arbitragem: estudos em homenagem ao Prof. Guido Fernandes da Silva Soares, São Paulo, Atlas, 2007, p. 279). Na mesma linha, e notadamente à luz do conceito de sentença contido na redação original do CPC: Yarshell e Bonício, Execução civil - novos perfis, São Paulo, RCS, 2006, pp. 16/17. Em sentido contrário, Hermes Zaneti Jr. defende a importância da conceituação das modalidades de interesses transindividuais a fim de facilitar o trabalho dos operadores do direito (La tutela de los derechos difusos, colectivos, e individuales homogêneos cit., p. 60). Ainda Pablo Gutiérrez de Cabiedes adverte que, no contexto do Código Modelo de Processos Coletivos para a IberoAmérica, diante dos conceitos ali adotados (que se assemelham em grande medida aos conceitos delineados no Código brasileiro de Defesa do Consumidor, com exceção da classificação binária do Código Modelo), não há justificativa para se desenvolver uma interpretação judicial restritiva em desfavor das pretensões deduzidas em ações coletivas, pois a dificuldade no enquadramento de dada pretensão em uma das categorias legais é mais retórica do que real (Comentários ao Código Modelo de Processos Coletivos cit., p. 40). 
pretensão na forma de ação coletiva (à luz do pedido tal qual deduzido em juízo) e menos a natureza do interesse posto em juízo ${ }^{89}$.

Além disso, a categorização abaixo não afasta a possibilidade de uma mesma conduta causar lesão na esfera de mais de uma categoria de direitos, o que confirma que a classificação a seguir apresentada tende à compreensão do fenômeno e a identificação do respectivo regime jurídico (notadamente o que diz respeito à coisa julgada), e não à obstacularização do acesso à justiça por meio do apego a formalismos inócuos.

\subsection{Interesses difusos}

No rol dos chamados interesses transindividuais definidos pelo Código de Defesa do Consumidor no artigo 81, despontam primeiro os interesses difusos (inciso I), que são aqueles de caráter indivisível, titularizados por pessoas indetermináveis, unidas por circunstâncias de fato.

A referência à índole indivisível dos interesses difusos corresponde à constatação de que, pertencendo a uma dada coletividade, eles não dizem respeito a nenhum de seus integrantes individualmente, embora sejam comuns a todos ${ }^{90}$. São, portanto, essencialmente coletivos e insuscetíveis de apropriação exclusiva. Um interesse difuso, como leciona Barbosa Moreira, "não comporta decomposição num feixe de interesses individuais que se justapusessem como entidades singulares, embora análogas. Há, por assim, dizer, uma comunhão indivisível”, porque "não se pode discernir, sequer idealmente, onde acabe a 'quota' de um e onde começa a e outro"91.

Consequência direta disso é que a solução do litígio é naturalmente incindível na medida em que o acolhimento ou a rejeição de um pedido formulado visando

\footnotetext{
${ }^{89}$ Venturi, Comentários ao Código Modelo de Processos Coletivos cit., pp. 29/31, lembrando as pertinentes palavras de Márcio Flávio Mafra Leal: “tal definición no és bienvenida bajo el aspecto teórico ni bajo el aspecto práctico (...) desde el punto de vista práctico, hay un inconveniente en definir los intereses e derechos conducidos por las acciones colectivas: el poder judicial se esforzará en asociar los requerimientos de las partes a esas categorías. Si no se vislumbra que los pedidos se encajan en una de las tres definiciones, se verá impelido a rechazar la acción, como si le fuera una condición especial de enjuiciamiento" (Notas sobre la definición de intereses difusos, colectivos e individuales homogéneos en el Código Modelo de Procesos Colectivos para Iberoamerica, in La tutela de los derechos difusos, colectivos, e individuales homogéneos, $2^{\text {a }}$ ed., México, Porrúa, 2004, pp. 40/42).

90 Daí a famosa indagação de Cappelletti: “a quem pertence o ar que respiro?” (cf. Formações sociais e interesses coletivos diante da justiça civil, Revista de Processo, n. 5, janeiro a março de 1977, p. 135, originalmente em Rivista di Diritto Processuale, 1975, n. 3, pp. 372/373).

${ }^{91}$ Barbosa Moreira, Tutela jurisdicional dos interesses coletivos ou difusos cit., pp. 195/196.
} 
à proteção de um interesse difuso afeta necessariamente toda a coletividade ${ }^{92}$, sendo inviável uma solução fragmentada ou decomposta.

De fato, quando pensamos na tutela aos titulares do direito ao meio ambiente saudável, a solução adjudicada pelo Estado é incindível, assim como inevitavelmente a lesão ao direito é sentida por todas indistintamente. Ou, em outras palavras "não se pode cogitar de atribuir-se a alguém, mais do que a outro(s) uma titularidade própria ou mais envergada" 93 .

Ou seja, sob o ponto de vista do sistema processual de índole individual, o desfecho da lide dependeria da formação de um litisconsórcio necessário unitário multitudinário - e até impraticável, a depender da intensidade da difusão do interesse.

Daí porque a doutrina inglesa, no exame da group litigation, menciona a existência do common interest, em referência não somente à coincidência dos interesses, mas à sua indivisibilidade ou unitariedade ${ }^{94}$. Na versão norte-americana das ações de grupo, a indivisibilidade de seu objeto impõe um tratamento obrigatoriamente coletivo (mandatory class action), a fim de que a solução do litígio seja adjudicada uniformemente a todos os seus titulares. Dessa idéia já extraímos premissa relevante para os próximos

\footnotetext{
92 Nesse sentido, conferir: Barbosa Moreira, Ações coletivas na Constituição Federal de 1988 cit., p. 188, em que o autor menciona o exemplo emblemático da mutilação de uma paisagem, cuja solução, seja qual for, aproveita a todos ("ou a paisagem é protegida, é preservada, e todos os interessados são juridicamente satisfeitos, ou a paisagem não é preservada, e nenhum dos interessados na sua preservação terá satisfação jurídica"); Mendes, Ações coletivas cit., pp. 216/217; Costa, O processo coletivo na tutela do patrimônio público e da moralidade administrativa cit., p. 45. Para uma análise desse aspecto sob a ótica econômica, conferir: Benjamin, A insurreição da aldeia global cit., p. 84/86, e Salles, Processo civil de interesse público cit., pp. 54/60, este último com referências à indivisibilidade da fruição dos public goods, cuja distribuição que deve passar por um processo político que "traduz um critério de justiça distributiva segundo o qual aqueles bens necessários à sobrevivência e desenvolvimento da coletividade são alocados a todo e qualquer de seus membros, não permitindo, portanto, qualquer utilização (ou apropriação) excludente, isto é, que impeça o pleno uso por outro de seus membros".

93 Cf. Eduardo Arruda Alvim, Apontamentos sobre o processo das ações coletivas, in Processo Civil Coletivo, coord. Rodrigo Mazzei e Rita Dias Nolasco, São Paulo, Quartier Latin, 2005, nota 3, p. 29. Essa ideia é valida, naturalmente, na análise da dimensão coletiva do conflito inerente a direito difuso. Mas, em interessante texto à luz da ação popular do direito português, Miguel Teixeira de Souza enfatiza que os direitos ditos difusos também têm correspondentes, no enfoque individual, a direitos subjetivos tradicionais (e no ordenamento português, essa correspondência serve para atribuir legitimidade ativa aos indivíduos para a defesa do meio ambiente, a teor do art. $52^{\circ}$, n. 3, da Constituição da República Portuguesa): “A titularidade desse direito ao ambiente e daquele dever de defesa do ambiente pode ser analisada em termos individuais ou supra-individuais. Quer dizer, aquele direito e aquele dever tanto podem ser perspectivados através da titularidade individual de cada um dos interessados directos, como podem ser considerados numa dimensão supra-individual, no âmbito da qual a todos e a cada um é reconhecido o direito de usufruir de um ambiente humano, sadio e equilibrado e incumbe o dever de preservar o ambiente e a qualidade de vida e de reagir contra os factores de degradação ambiental. (...) Essa legitimidade difusa é, por outras palavras, uma legitimidade concorrente, pois que pertence a um número indeterminado de sujeitos" (cf. Legitimidade processual e ação popular no direito do ambiente, in Revista de Processo, n. 76, ano 19, outubro a dezembro de 1994, pp. 127/140, notadamente, pp. 128 e 136).

${ }^{94}$ Mendes, Ações coletivas cit., p. 215.
} 
temas que serão aqui estudados: se a solução deve ser uniforme, a eficácia da sentença proferida em ação coletiva versando interesses difusos atinge todos os membros do grupo $^{95}$.

Ligada ao caráter indivisível, e da impossibilidade de apropriação individual de seu objeto por um dos titulares, está a ideia de que, por natureza, os direitos difusos são essencialmente extrapatrimoniais ${ }^{96}$. Dessa forma, na esfera da reparação, a ressarcibilidade pecuniária de seus titulares é sempre indireta. E por isso, o produto de eventual indenização fixada por conta da violação desses direitos não reverte a um titular específico, sequer ao Estado, mas sim, na hipótese regulamentada pelo direito brasileiro, a um fundo que destinará tais verbas à promoção dos bens difusos atingidos (art. 13 da Lei $7.347 / 1985)$.

A característica de indeterminação dos titulares dos interesses difusos é dado variável. Ocorre que, em hipótese na qual se discuta a preservação das dunas do litoral brasileiro ${ }^{97}$, os interesses envolvidos são tão fluidos e dispersos que tendem a se aproximar, nesse quesito da indeterminação, do chamado interesse geral ou interesse público primário $^{98}$.

\footnotetext{
95 “Como são indeterminados ou indetermináveis os membros da comunidade titular do direito difuso, não é possível excluir quem quer que seja da titularidade desta pretensão, em virtude da existência de um processo absolutamente inclusivo" (cf. Venturi, Comentários ao Código Modelo de Processos Coletivos cit., p. 34).

${ }_{97}^{96}$ Cf. Mafra Leal, Notas sobre la definición cit., p. 40.

97 Exemplo extraído de precedente do STJ que incluiu as dunas catarinenses no objeto de proteção da legislação ambiental: REsp 1.069.155/SC, relator Min. Mauro Campbell, j. 7/12/2010.

${ }^{9}$ Assim assevera Mazzilli (A defesa dos interesses difusos em juízo cit., 16 ${ }^{\mathrm{a}}$ ed., p. 48). Ainda sobre esse aspecto, Aluísio Mendes menciona que a indeterminabilidade do interesse difuso não é absoluta, bastando que "seja difícil ou irrazoável" (Ações coletivas cit., p. 224). Em linha oposta, Antonio Gidi sustenta que os direitos difusos não se referem a titulares indeterminados; pelo contrário, o titular dos direitos difusos é perfeitamente determinável, na medida em que dizem respeito a uma coletividade (Derechos difusos, colectivos e individuales homogéneos cit., p. 30). Vale também conferir a análise de Susana Henriques da Costa (O processo coletivo na tutela do patrimônio público cit., pp. 61/65) que distingue os interesses gerais, difusos e coletivos (gêneros da espécie interesse público) de acordo com uma escala decrescente de difusão e fluidez, pois "interesses geral é um interesse de toda a comunidade política, um interesse que a todos diz respeito e não somente a uma determinada coletividade, como ocorre com os interesses difusos e coletivos. Ele é mais disperso e fluido se comparado a esses últimos". Ada Pellegrini Grinover (Novas tendências na tutela jurisdicional dos interesses difusos cit., p. 89) parece considerar como gênero os interesses metaindividuais, dos quais são espécies os interesses públicos (à ordem pública, à segurança pública), difusos e coletivos. Discordando da noção de que há uma relação de gênero-espécie entre as categorias interesse público e interesse difuso, Herman Benjamin observa que "o gênero não pode ter traços ausentes da espécie. Gênero, aqui, é interesse supraindividual, no qual vamos localizar, cada qual com um perfil próximo, mas diferenciado, as categorias do interesse público, difusos, coletivo stricto sensu e individual homogêneo" (cf. A insurreição da aldeia global cit., p. 93). Concordando com a noção de que interesse público é espécie do gênero interesses supraindividuais, Pedro da Silva Dinamarco afirma que "Público é o interesse geral da sociedade, concernente a todos e não só ao Estado" (cf. Ação civil pública cit., p. 220). Por sua vez, Eurico Ferraresi exclui da categoria de interesse supraindividual a defesa do erário, que detém titular determinado (a pessoa jurídica de direito público), de modo que, do gênero interesse geral, somente a espécie interesse na
} 
De outra parte, no caso de eventual propaganda enganosa, veiculada em jornal de reduzida tiragem, dirigida a um público restrito, em dada cidade interiorana, é relativamente baixo o grau de dispersão dos sujeitos prejudicados.

Por sua vez, as circunstâncias de fato que agregam os titulares dos interesses difusos são normalmente acidentais e fluidas, consoante leciona Ada Pellegrini Grinover ${ }^{99}$. É possível dizer que os titulares dos interesses difusos estão aglutinados apenas ocasionalmente, sendo as circunstâncias de fato comum uma mera contingência ${ }^{100}$, o que significa que não há necessariamente vínculo jurídico entre os mesmos.

Tal como foi bem destacado por Barbosa Moreira, o vínculo jurídico pode até inexistir em se tratando de interesses difusos, já que "os interesses de cuja proteção se cogita não surgem em função dele, mas antes se prendem a dados de fato, muitas vezes acidentais e mutáveis" ${ }^{101}$. Assim, no exemplo clássico da doutrina, os moradores de determinada região afetada por fábrica poluente não mantêm vínculos entre si na ocasião em que desfrutam do bem jurídico difuso e afetado por ato ilícito. Neste caso, portanto, a circunstância de fato comum entre os seus titulares é a habitação na região atingida pelo poluente - o que é dado de notória precariedade.

Ou ainda, para a defesa dos direitos de consumidores submetidos a uma dada propaganda abusiva, a pretensão a ser deduzida com o fim de cessar a sua veiculação independe de qualquer liame ou organização dos destinatários da propaganda entre si.

Também interessa observar recente reflexão de Susana Henriques da Costa a respeito de um elemento diferenciador entre os interesses difusos e os chamados interesses gerais da sociedade. Segundo a autora, a fruição de um direito difuso é direta e sensível a todos os membros da coletividade; o mesmo ocorre com o prejuízo à fruição desse direito. Assim, ilustra, "todos os membros da mesma cidade sentirão de forma negativa, em seu dia a dia, os efeitos da instalação de uma fábrica que polua o autor que todos respiram".

Ao contrário, o que caracteriza a noção de interesse geral, que diz respeito à toda comunidade política, a sua fruição indireta por seus beneficiários. Exemplificando, a

defesa do patrimônio cultural se qualifica como verdadeiro interesse supraindividual (Ferraresi, Ação popular cit., pp. 52/54).

${ }^{99}$ Novas tendências na tutela jurisdicional dos interesses difusos cit., p. 89.

${ }^{100}$ Mancuso, Interesses difusos: conceito e colocação no quadro geral dos 'interesses' cit., pp. 165/179 (especialmente pp. 173/175).

${ }^{101}$ Cf. Barbosa Moreira, Tutela jurisdicional dos interesses coletivos ou difusos cit., p. 194. 
autora supõe a seguinte hipótese: "quando a polícia investiga e prende uma quadrilha de sequiestradores, somente é diretamente beneficiado o refém mantido em cativeiro. Nenhum outro membro da coletividade é diretamente beneficiado pela conduta estatal. A despeito disso, o interesse geral da segurança pública é satisfeito" 102 .

Outra nota peculiar dos interesses difusos é a intensa conflituosidade entre a subcategoria dos "interesses macrossociais". Sobre isso, Antonio Gidi observa que "É da própria natureza dos grupos que seus membros divirjam em pontos importantes da convivência social, especialmente quando se envolvem grupos, fatos e situações complexas. A complexidade da situação, portanto, por si só, não deve inviabilizar a tutela coletiva de uma pretensão válida, sob pena de prejudicar o grupo e beneficiar injustamente a parte contrária. Com efeito, não se pode condicionar o cabimento de uma class action à improvável situação de unanimidade entre os membros de um grupo" ${ }^{103}$.

Nesse contexto, Ada Pellegrini Grinover ilustra: "ao grupo titular de um interesse costuma-se contrapor o interesse de outro grupo. $\mathrm{O}$ interesse à contenção dos custos de produção e dos preços contrapõe-se ao interesse à criação de novos postos de trabalho, à duração dos bens colocados no comércio, etc. $\mathrm{O}$ interesse à preservação das belezas naturais contrapõe-se ao interesse da indústria edilícia, ou à destinação de áreas verdes a outras finalidades; o interesse ao transporte automobilístico não poluente e barato contrapõe-se ao interesse por um determinado tipo de combustível; o interesse à informação correta e completa contrapõe-se ao interesse político em manter um mínimo de controle sobre os meios de comunicação de massa etc." 104 .

\footnotetext{
${ }^{102}$ Cf. Costa, O processo coletivo na tutela do patrimônio público e da moralidade administrativa cit., pp. 49/50 e 64. Na concepção de Miguel Teixeira de Sousa, os interesses difusos não são interesses públicos, "porque a sua titularidade não pertence a nenhuma entidade ou órgão público" (Cf. Legitimidade processual e ação popular no direito do ambiente cit., p. 128).

103 Cf. Gidi, Class action como instrumento de tutela coletiva de direitos - as ações coletivas em uma perspectiva comparada, São Paulo, Revista dos Tribunais, 2007, pp. 118/119. Ainda a respeito disso, confiram-se: Benjamin, A insurreição da aldeia global contra o processo civil clássico cit., pp. 93/94, que menciona a ausência de unanimidade social, como dado "fundamental para apartá-los do interesse público"; Mancuso, Interesses difusos: conceito e colocação no quadro geral dos 'interesses' cit., pp. 174/175, em que o autor menciona o intenso "entrechoque entre massas de interesses", com referência à lição de Massimo Villone de que os interesses difusos se imiscuem no campo político (La collocazione istituzionale dell'interesse diffuso, in La tutela degli interessi diffusi nel diritto comparato, Giuffrè, Milão, 1976, pp. 78 e 87).

${ }^{104}$ Cf. Grinover, Novas tendências na tutela jurisdicional dos interesses difusos cit., p. 91. Mazzilli menciona exemplos elucidativos: "um grupo que, ao invocar o direito ao meio ambiente sadio, deseje o fechamento de uma fábrica, e as de outro grupo de pessoas que dependam, direta ou indiretamente, da manutenção dos respectivos empregos ou da continuidade da produção industrial para sua própria subsistência", ou "os que desfrutam do conforto dos aeroportos urbanos, ou da animação dos chamados trios elétricos carnavalescos, em oposição aos interesses dos que se sentem prejudicados pela correspondente poluição sonora" (A defesa dos interesses difusos em juízo cit., 22a ed., p. 51).
} 


\subsection{Interesses coletivos stricto sensu}

Em grande parte, os chamados interesses coletivos stricto sensu ou, simplesmente, interesses coletivos, assemelham-se muito com os interesses difusos. Tamanha é a similitude que muitos autores não encontram razão para a construção teórica que preconiza a sua classificação em categorias autônomas ${ }^{105}$.

Para o escopo do presente trabalho, embora todos os aspectos do regime jurídico dos interesses difusos sejam válidos para a disciplina dos interesses coletivos stricto sensu, atentaremos para a classificação do vigente Código de Defesa do Consumidor que ainda os diferencia.

Nesse diapasão, os interesses coletivos igualmente não comportam fruição ou apropriação fragmentada (ou seja, são indivisíveis ${ }^{106}$ ), mas se distinguem dos interesses difusos, segundo a doutrina de Ada Pellegrini Grinover, porque se fala de "interesses coletivos quando existe um grupo de pessoas, com interesses comuns que só seriam comunitariamente perseguíveis, ao passo que o interesse difuso não se caracteriza por qualquer momento associativo" ${ }^{107}$. Em outras palavras, há um vínculo comum a todos os seus membros, seja entre si (por circunstâncias de fato) ou em face do sujeito que pratica o ilícito, agregando os titulares dessa gama de direitos por seu caráter corporativo ${ }^{108}$.

105 O Código Modelo de Processos Coletivos para a Ibero-América já abandonou a distinção entre direitos difusos e direitos coletivos stricto sensu (conforme redação já mencionada constante do seu artigo $1^{\circ}$ ), acatando sugestão de Antonio Gidi (Código de Processo Civil Coletivo - um modelo para países de direito escrito, São Paulo, Revista dos Tribunais, Revista de Processo, n. 111, ano 28, julho a setembro de 2003, p. 194). Na mesma linha da inexistência de distinção ontológica entre os direitos difusos e coletivos, vide Elton Venturi, Comentários ao Código Modelo de Processos Coletivos cit., pp. 34/35, e na mesma obra, Pablo Gutiérrez de Cabiedes, p. 44, para quem "la comunidad de referencia del interés colectivo está caracterizada por una mayor permanencia, a diferencia de la del interés difuso, que lo está más por las notas de mutabilidad u ocasionalidad". Em sentido contrário, entendendo imprescindível a distinção entre as duas categorias por conta dos regimes diversos de eficácia da sentença: Mendes, Ações coletivas cit., p. 223.

106 Sobre esse aspecto, importa frisar que, na concepção de Vigliar, os interesses coletivos stricto sensu são indivisíveis somente por vontade do legislador, pois não se descarta a possibilidade de cada um de seus titulares buscarem sua proteção de maneira individualizada, por força do princípio da inafastabilidade do controle jurisdicional. Assim, "os interesses coletivos em sentido estrito representam uma especial categoria de interesses individuais homogêneos (...). Especial, pois, ao contrário destes, a união dos interessados não ocorre por meras circunstâncias fáticas, e sim pela existência de uma comum e única relação jurídica" (cf. Interesses individuais homogêneos e seus aspectos polêmicos cit., p. 37).

107 Cf. Grinover, verbete Interesses difusos, Enciclopédia Saraiva do Direito, v. 45, nota 4, p. 413. Nas palavras de Mancuso, enquanto o interesse coletivo resulta do homem em sua projeção corporativa, o interesse difuso considera o homem simplesmente enquanto ser humano (Interesses difusos - conceito e legitimação para agir cit., $6^{\mathrm{a}}$ ed., p. 86).

${ }^{108}$ Denti, Giustizia e Partecipazione nella tutela dei nuovi diritti, in Participação e Processo cit., p. 16. Interessante alusão é feita por Rodolfo de Camargo Mancuso aos comentários de Vincenzo Caianiello (Introduzione, in Atti del XXIII Convegno di Studi di Scienza dell'Amministrazione, Milão, Giuffrè, 1978, p. 26): o interesse difuso "è un interesse latente nella comunità ma privo di titolare, cioè adespota, e l'interesse collettivo è quello che emergendo dallo stato di latenza, si coagula intorno a un gruppo anche se spontaneo e 
Nessa seara, Calmon de Passos asseverou que o objetivo das ações coletivas para a defesa de direitos coletivos stricto sensu é "não à defesa dos 'direitos' dos seus membros ou associados, tout court, sim dos 'direitos' de seus membros ou associados cujo substrato material seja um 'interesse de membro', ou 'interesse de associado""109, enfatizando, portanto, o viés corporativo ${ }^{110}$ do interesse coletivo.

Ao lado disso, distinção também aceita é aquela construída segundo o critério da determinabilidade. Os interesses coletivos stricto sensu, embora também indivisíveis, se destacam por seus titulares serem determináveis, ao passo que os interesses difusos são de tal maneira pulverizados, que não comportam razoável determinação de seus sujeitos ativos ${ }^{111}$.

Ilustrando essa distinção, pode-se dizer que, por menor que seja uma comunidade rural afetada por dado poluente exalado por uma fábrica, é inviável determinar os futuros moradores da região cujo direito ao meio ambiente sadio também terá sido lesado naquela situação. Ao contrário, com os interesses coletivos stricto sensu, na medida em que aglutinados necessariamente por uma relação jurídica base, ocorre que se torna factível determinar quais serão os atingidos pela cláusula abusiva em um contrato de consumo que se pretende invalidar (determinabilidade), muito embora a abusividade da

organizzantosi solo in funzione di quell'interesse, che ne reclama la rilevanza" (cf. Interesses difusos cit., $7^{\text {a }}$ ed., 2011, p. 51).

${ }^{109}$ Cf. Mandado de segurança coletivo, mandado de injunção, habeas data - Constituição e processo, Rio de Janeiro, Forense, 1989, p. 13.

${ }_{110} \mathrm{O}$ que não significa afetar a concepção de grupo, no estudo dos direitos coletivos stricto sensu, necessariamente a uma categoria profissional. Corporativismo deve ser lido, aqui, como algo relativo a ser um grupo de pessoas submetidas às mesmas regras. Susana Henriques da Costa alude à situação na qual os interesses de pais atingidos pela regulamentação de reajuste de mensalidades escolares se comportam como interesses coletivos stricto sensu (O processo coletivo na tutela do patrimônio público e da moralidade administrativa cit., p. 51). Sobre esse aspecto, Luiz Paulo da Silva Araújo Filho também esclarece que: "Boa parte da doutrina italiana, porém, nos últimos anos, vem distinguindo os interesses difusos dos interesses coletivos porque estes, para se caracterizarem, exigiriam uma organização estabelecida para a obtenção dos interesses coligados, vinculados, que formariam, por isso mesmo, o fim comum. Os interesses coletivos, em vista disso, abrangeriam uma comunidade de pessoas genericamente organizada, mas identificável, como, por exemplo, os alunos de uma faculdade ou de uma universidade. Já nos interesses difusos, não existe a autoorganização, por tratar-se de interesses não organizados, nem organizáveis a priori, referente a um número ilimitado de sujeitos" (cf. Ações coletivas: a tutela jurisdicional dos Direitos Individuais Homogêneos, Rio de Janeiro, Forense, 2000, pp. 13/14). No mesmo sentido, vide Eduardo Arruda Alvim (Apontamentos sobre o processo das ações coletivas cit., pp. 30/31), observando que não há desordenamento ou profusão na titularidade dos direitos coletivos stricto sensu. Ainda a respeito, Barbosa Moreira esclarece que, na realidade dos direitos coletivos stricto sensu, "a existência da relação-base, perfeitamente caracterizada, delimita melhor a coletividade e lhe dá maior coesão" (cf. A ação popular no direito brasileiro cit., p. 112).

${ }^{111}$ Sobre essa distinção, conferir: Mancuso, Interesses difusos - conceito e legitimação para agir cit., $6^{\mathrm{a}}$ ed., pp. 85/86 (com ênfase à necessidade teórica e também prática da diferenciação das duas categorias) e Interesses difusos: conceito e colocação no quadro geral dos "interesses" cit., p. 170 (em que o autor destaca o mínimo de organização e a afetação dos interesses coletivos a grupos determinados que serão os seus portadores em juízo). 
cláusula em relações de consumo não afete exclusivamente a algum consumidor concretamente lesado, mas a todos eles (indivisibilidade).

Portanto, pode-se traçar duas notas diferenciadoras dos ditos interesses coletivos stricto sensu com relação aos interesses difusos: a determinabilidade e a relação base agregando os seus titulares entre si ou com a parte contrária da situação jurídica.

\subsection{Interesses individuais homogêneos}

Disciplinada de forma inédita no Brasil pela Lei 8.078/1990, a categoria dos interesses individuais homogêneos é fruto de inspiração nas class actions for damages norte-americanas. Naquele sistema, consoante descreve Ada Pellegrini Grinover ${ }^{112}$, as class actions remontam à Bill of Peace do século XVII e, particularmente, as class actions for damages (tratadas como spurious class action no regime das Federal Rules of Civil Procedure de 1938), ganharam nova roupagem em 1966.

No Código brasileiro de Defesa do Consumidor, os denominados interesses individuais homogêneos, a exemplo da lição norte-americana, foram concebidos como aqueles "decorrentes de origem comum" (artigo 81, inciso III). De tal expressão decorrem significativas peculiaridades, que merecem ser estudadas com o devido vagar. Também terão nossa atenção alguns aspectos em que o legislador de 1990 não foi expresso, mas que influem com grande relevância no tratamento processual dos interesses individuais homogêneos.

Logo do enunciado contido no inciso III do artigo 81 do Código de Defesa do Consumidor, que conferiu a essa categoria de interesses o nomen iuris "individuais homogêneos", infere-se que o legislador se propôs a disciplinar interesses que não são coletivos por natureza, mas sim essencialmente individuais. São interesses que ostentam, a condição de direitos subjetivos com titulares determináveis, ou até bem determinados ${ }^{113}$ e, em si mesmos, nada têm de coletivo.

${ }^{112}$ Cf. Da class action for damages à ação de classe brasileira: os requisitos de admissibilidade, in Revista de Processo, ano 26, n. 101, janeiro a março de 2001, pp. 12/13.

${ }^{113}$ Vale destacar que a (in)determinabilidade dos titulares não define a categoria dos interesses individuais homogêneos. Exemplo interessante de indeterminação dos titulares dos direitos individuais homogêneos é dado por Francis Caballero, ao estudar a fluid recovery do direito norte-americano. Segundo o autor, é inidentificável toda a classe dos consumidores lesados pelo aumento ilícito da tarifa de táxi em certo período em dado centro metropolitano: "Ainsi dans l'affaire des taxis de Los Angeles (173) coupables d'une hausse illicite des tarifs, l'impossibilité de connaître tous les clients des taxis pendant la période considérée a conduit le juge à ordenner, à titre de réparation, une baisse de prix equivalente à la hausse illégale" (cf. De 
Teori Albino Zavascki ${ }^{114}$ observou que não se trata de uma nova categoria de direitos, mas sim de direitos tratados processualmente de forma inédita.

Ocorre que o seu tratamento molecular, embora não obrigatório, constitui-se num mecanismo superação de obstáculos ao acesso à justiça inerentes às mesmas pretensões quando deduzidas individualmente. O seu tratamento coletivo é, então, fruto da "ampliação da funcionalidade das ações coletivas" ${ }^{115}$, como bem mencionou Elton Venturi, dadas as limitações ao litisconsórcio multitudinário do sistema processual de tutela individual ${ }^{116}$.

Assim também é o direito de um consumidor à reparação de um dano oriundo do defeito do produto: fácil notar sua essência subjetiva, já que o direito pode ser exercido e tutelado de forma individual independentemente da insatisfação e da atuação de outros titulares de direito semelhante. Mas, quando aglutinados para ganhar tratamento molecular, estamos diante de, segundo Rodolfo de Camargo Mancuso, "interesses que apenas são coletivos na forma, permanecendo individuais quanto à finalidade perseguida, o que significaria um exercício coletivo de interesses individuais" ${ }^{\prime 17}$.

Os interesses individuais homogêneos diferem, desse modo, dos interesses essencialmente coletivos, pois estes significam uma síntese dos interesses individuais, "nascida a partir do momento em que certos interesses, atraídos por semelhança e harmonizados pelo fim comum, se amalgamam" e formam uma entité genérale et abstraite qui absorbe et dépasse la somme des intérêts individuels de ses membres ${ }^{118}$, enquanto que por sua vez, os interesses individuais homogêneos, quando coletivamente considerados, nada mais são do que a simples soma dos interesses individuais, que ganha uma "dimensão

l'archaisme procédural a l'action de groupe, in Revue International de Droit Comparé, 1985, n. 2, p. 247, apud Paulo Duarte, Recurso e acórdão do Supremo Tribunal de Justiça de Portugal cit., p. 141).

${ }^{114}$ Processo coletivo cit., $4^{\mathrm{a}}$ ed., p. 145.

115 Cf. Venturi, Comentários ao Código Modelo de Processos Coletivos cit., p. 35. Teori Albino Zavascki menciona que a ação coletiva que remete à tutela de direitos individuais homogêneos consiste, no atual cenário legislativo brasileiro, em "instrumento processual alternativo ao litisconsórcio ativo facultativo", de modo que a sua introdução no ordenamento responde a anseios de ordem prática e de eficiência da máquina judiciária (op. cit., $4^{\mathrm{a}}$ ed., p. 151).

${ }^{116}$ Conforme disposição contida no CPC de 1973: “Art. 46. (...) Parágrafo único. O juiz poderá limitar o litisconsórcio facultativo quanto ao número de litigantes, quando este comprometer a rápida solução do litígio ou dificultar a defesa (...)".

${ }_{117}$ Cf. Mancuso, Interesses difusos - conceito e legitimação para agir cit., $6^{a}$ ed., p. 83.

${ }^{118}$ Cf. Mancuso, Interesses difusos: conceito e colocação no quadro geral dos 'interesses' cit., citando a dicção de H. Solus e R. Perrot. 
social em razão do grande número de interessados e das graves repercussões na comunidade" $" 119$.

A situação conflituosa envolvendo aquele consumidor do exemplo mencionado, titular de direito individual, de um lado, e o causador do dano, de outro, embora possa ter um desfecho pelas vias tradicionais do processo civil individualista, ostenta uma dimensão coletiva possível de ser solucionada pelos instrumentos coletivos de resolução adjudicada de controvérsias. Ou, ainda, na situação ilustrada por Barbosa Moreira $^{120}$, na qual há fraude financeira com diversas vítimas, o sistema autoriza proteção de espectro mais amplo, a despeito de o conflito poder ser solucionado isolada e individualmente e o proveito jurídico ser repartido entre os diversos titulares.

Então, ainda que preservada a via individual de tutela jurisdicional, interesses individuais, desde que homogêneos como se verá adiante, podem se aglutinar para tornarem-se "acidentalmente coletivos", como diria Barbosa Moreira ${ }^{121}$, ou, nas palavras de Teori Albino Zavascki ganharem apenas tratamento coletivo ${ }^{122}$, conservando sua natureza individual. Sendo assim, os interesses individuais homogêneos, embora se assemelhem aos interesses difusos no aspecto da origem comum, distanciam-se deles por sua natureza essencialmente individual e, portanto, divisível (viabilidade de fruição fragmentada). Ou seja, "O quantum de cada um [dos seus titulares] é perfeitamente mensurável"123.

Quando ressaltou a necessidade de terem os direitos individuais "origem comum" para merecerem tratamento coletivo, o legislador referiu-se à coincidência da fonte, próxima ou remota, de fato ou de direito, da situação conflituosa. Ou seja, da equivalência entre a causa de pedir dos diversos titulares individuais.

A esse respeito, Ada Pellegrini Grinover anota que "a origem comum (causa) pode ser próxima ou remota. Próxima, ou imediata, como no caso da queda de um avião, que vitimou diversas pessoas; ou remota, mediata, como no caso de um dano à saúde, imputado a um produto potencialmente nocivo, que pode ter tido como causa próxima as condições pessoais ou o uso inadequado do produto. Quanto mais remota for a

\footnotetext{
${ }^{119}$ Cf. Barbosa Moreira, Tutela jurisdicional dos interesses coletivos ou difusos cit., p. 197.

${ }^{120}$ Ações coletivas na Constituição Federal de 1988 cit., p. 188.

${ }^{121}$ Cf. Tutela jurisdicional dos interesses coletivos ou difusos cit., p. 195.

${ }^{122}$ Processo coletivo cit., $4^{\mathrm{a}}$ ed., p. 35.

123 "Ao contrário, ninguém poderia apurar a sua parcela de interesse em relação a determinada paisagem natural, por exemplo" (cf. Vigliar, Interesses individuais homogêneos e seus aspectos polêmicos cit., p. 41).
} 
causa, menos homogêneos serão os direitos"124. Vale registrar a opinião de Teori Albino Zavascki ${ }^{125}$, para quem "homogeneidade não é sinônimo de igualdade, mas de afinidade".

Em outras palavras, o interesse que poderá ser tratado coletivamente, ainda que individual, é aquele surgido de fatos ou de fundamentos de direito equivalentes a todos os lesados. No exemplo aqui já adotado, o consumo de um dado produto defeituoso é a origem comum do dano causado individualmente a cada consumidor desse mesmo produto. Assim, a coincidência de situações fáticas é apenas acidental.

Dessa ótica, a origem comum é particular aos interesses individuais homogêneos, pois, no caso dos interesses coletivos stricto sensu, a noção de relação jurídica base mantida entre os titulares ou os titulares e a parte contrária tem traço diferenciado. É dela que provém a lesão ao grupo ${ }^{126}$. Em contrapartida, no trato dos interesses individuais homogêneos, a ocorrência da lesão "coletiva" (na sua dimensão processual) independe de qualquer vínculo preexistente entre os respectivos titulares.

Feitas essas primeiras notas sobre a natureza dos interesses individuais homogêneos em si mesmos, é a segunda expressão contida no inciso III do artigo 81 do Código de Defesa do Consumidor que desperta maiores curiosidades e aflições aos que se dedicam ao estudo do tema. Isso porque, a origem comum não é suficiente para qualificar os interesses individuais como homogêneos, dado que as peculiaridades pessoais de seus titulares ou outros fatores podem distanciar um interesse de outro, a despeito de terem a mesma origem.

\footnotetext{
${ }^{124}$ Cf. Da class action for damages à ação de classe brasileira: os requisitos de admissibilidade cit., p. 21. No mesmo sentido: Eurico Ferraresi aponta que: "A origem comum significa a causa da demanda, que pode ser de fato ou de direito. Por homogêneo, entende-se o que apresenta unidade, adesão entre seus elementos, possuindo semelhança de estrutura e função" (op. cit., p. 283). Para Teori Albino Zavascki, os elementos formadores do "núcleo de homogeneidade" decorrem "de causas relacionadas com a gênese dos direitos subjetivos. Trata-se de direitos originados da incidência de um mesmo conjunto normativo sobre uma situação fática idêntica ou assemelhada. Essa circunstância genética produz um conjunto de direitos subjetivos com, pelo menos, três aspectos fundamentais de identidade: (a) relacionado à própria existência da obrigação, (b) o que diz respeito à natureza da prestação devida e (c) o concernente ao sujeito passivo (ou aos sujeitos passivos), comuns a todo eles" (cf. Processo coletivo cit., $4^{\mathrm{a}}$ ed., p. 146).

${ }^{125}$ Cf. Comentários ao Código Modelo de Processos Coletivos cit., p. 279.

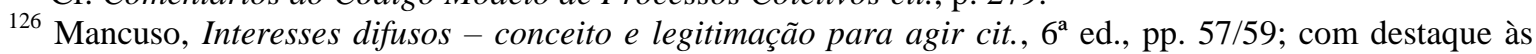
considerações do autor a respeito da usual concomitância de todas as categorias de interesses em uma mesma demanda: "Tomemos como exemplo um aumento ilegal de prestações de um consórcio. O interesse em ver reconhecida a ilegalidade do aumento é compartilhado pelos integrantes do grupo de forma indivisível e não quantificável: a ilegalidade do aumento não será maior para quem tenha mais cotas: a ilegalidade será a mesma para todos (interesses coletivos). Entretanto, será divisível a pretensão de repetição do que se tenha pagado ilegalmente a mais; tendo havido pagamentos, os prejuízos serão individualizáveis (interesses individuais homogêneos). Sem dúvida, na mesma ação civil pública, será possível pedir não só a nulidade do aumento ilegalmente aplicado, a ser decidida identicamente para todos os integrantes do grupo (interesse coletivo), como também a repetição do indébito, que há de favorecer cada integrante do grupo, de forma divisível e individualmente variável (interesses individuais homogêneos)".
} 
De fato, até aqui já é possível concluir que se exige um alto grau de similitude entre os direitos titularizados pelos membros de uma dada coletividade. Mas tão só essa constatação não basta.

Como segunda condição para merecerem tratamento coletivo, os interesses individuais precisam ostentar a qualidade de "homogêneos". Para a noção particular de homogeneidade, a doutrina nacional especializada ${ }^{127}$, que se encarregou da redação do anteprojeto do Código de Defesa do Consumidor, encontra parâmetros na regra (b)(3) das já mencionadas Federal Rules of Procedure Civil de 1966, que estabelecem como threshold requirements (requisitos preliminares) da class action for damages que: "the court finds that the questions of law or fact common to class members predominate over any questions affecting only individual members, and that a class action is superior to other available methods for fairly and efficiently adjudicating the controversy".

Esse enunciado, que inspirou a redação do Código Modelo de Processo Coletivos para a Ibero-América ${ }^{128}$, possui dois desdobramentos teóricos.

O primeiro deles é a exigência da chamada prevalência das questões comuns (commonality, na concepção da common law norte-americana) ${ }^{129}$ sobre as peculiaridades individuais. Dito isso de outro modo, os interesses individuais podem ser tratados coletivamente se a dimensão coletiva do conflito, ou as questões de fato (v.g. causa do dano) ou de direito (v.g. natureza da responsabilidade do agente causador do dano) comuns aos respectivos titulares, predominar sobre a dimensão individual.

Sob a perspectiva do objeto do processo, é possível afirmar que essa similitude de questões se traduz na constatação de que os titulares dos direitos individuais

\footnotetext{
127 "será necessário aferir a aplicabilidade, ao sistema brasileiro, do critério adotado nas class actions norte americanas da "prevalência da dimensão coletiva sobre a individual"” (cf. Watanabe, Código Brasileiro de Defesa do Consumidor cit., $8^{\mathrm{a}}$ ed., p. 807). E ainda: Grinover, Da class action for damages à ação de classe brasileira: os requisitos de admissibilidade cit., pp. 21/24 e 26/27, com a importante observação de que "Não se trata, aqui, de acolher incondicionalmente as particularidades de institutos estrangeiros. (...) Mas se a realidade fática é a mesma, se as questões práticas são semelhantes, se há princípios gerais comuns (acesso à justiça, efetividade do processo, justiça das decisões, devido processo legal, certamente a experiência estrangeira poderá oferecer parâmetros de inegável utilidade". Por outro lado, há parcela respeitável da doutrina que nega a aplicação dos pressupostos da prevalência e da superioridade ao direito pátrio, aduzindo que a origem comum resume a homogeneidade: Venturi, Comentários ao Código Modelo de Processos Coletivos cit., p. 53.

128 “Art. $2^{\circ}$. Requisitos da ação coletiva (...) Par. $1^{\circ}$. Para a tutela dos interesses ou direitos individuais homogêneos, além dos requisitos indicados nos $\mathrm{n}^{\circ} \mathrm{s}$ I e II deste artigo, é também necessária a aferição da predominância das questões comuns sobre as individuais e da utilidade da tutela coletiva no caso concreto".

129 Nas palavras de Pablo Gutiérrez de Cabiedes, trata-se do chamado núcleo de relevância comum (Comentários ao Código Modelo de Processos Coletivos cit., p. 66).
} 
podem postular tutela jurisdicional com base na mesma causa de pedir ${ }^{130}$. A contrario sensu, "prevalecendo as questões individuais sobre as comuns, os direitos individuais serão heterogêneos e o pedido de tutela coletiva se tornará juridicamente impossível"131.

Situação ilustrativa de direitos individuais heterogêneos foi submetida ao exame do Tribunal de Justiça do Estado de São Paulo que, com acerto, concluiu pela inviabilidade da tutela coletiva então pretendida. Consta que o Ministério Público estadual almejava a reparação de inúmeros segurados que tiveram a indenização securitária negada pela seguradora com base em documentação supostamente fraudulenta que concluía por fraude praticada pelo segurado, consistente na anterior alienação, no Paraguai e na Bolívia, do veículo objeto do contrato de seguro.

Na ocasião, de acordo com o material de prova trazido aos autos, observouse que: "não se está a afirmar, com essa conclusão, que não haja a seguradora demandada praticado alguns dos ilícitos que lhe são imputados, mas apenas, que a tutela civil dos danos decorrentes, pela via coletiva, mostra-se tecnicamente inadequada, à ausência de prova de que o indigitado fato ilícito tenha ocorrido em todos os casos de negativa de indenização e com as mesmas características em cada uma das hipóteses". Ou seja, naquele caso, a margem de heterogeneidade superou o núcleo de homogeneidade. Dessa forma, concluiu a Corte Paulista, dada a necessidade de aferir, caso a caso, se a negativa de indenização foi ilícita e se os documentos que subsidiaram a conduta da demandada foram fraudulentos, inexistiu homogeneidade a autorizar o processamento da pretensão reparatória na forma coletiva ${ }^{132}$.

\footnotetext{
${ }^{130}$ Em obra especialmente dedicada ao exame dos elementos objetivos da demanda que envolve direitos individuais homogêneos, José Marcelo Menezes Vigliar complementa: "a conclusão de que existe uma causa de pedir idêntica a cada um dos interessados que se encontra em situação que o identifique com o grupo constitui mecanismo de extrema importância, quer para que se viabilize a dedução da pertinência do pedido, quer para que se verifique se, efetivamente, se está diante de interesses individuais homogêneos, ou se prevalecem os aspectos individuais sobre os coletivos" (cf. Interesses individuais homogêneos e seus aspectos polêmicos cit., p. 45).

${ }^{131}$ Grinover, Da class action for damages à ação de classe brasileira cit., p. 22. Vale ainda conferir: Vigliar: "prevalecendo aspectos pessoais aos coletivos, a tutela coletiva, embora viável, em tese, diante da origem comum, torna-se impossível" (cf. Interesses individuais homogêneos e seus aspectos polêmicos cit., p. 16), Luiz Paulo da Silva Araújo: "A ação referente a interesses individuais, portanto, vale repisar, só admite a feição coletiva porque - e enquanto! - a homogeneidade desses direitos, decorrentes de origem comum, permite que sejam desprezadas e necessariamente desconsideradas as peculiaridades agregadas à situação pessoal e diferenciada de cada interessado. Tornando-se relevante, porém para o julgamento do feito, à vista da demanda, verificar aspectos pessoais e diferenciados dos titulares dos direitos individuais, a tutela coletiva torna-se absolutamente inviável", isso tudo para que não se formule pretensão, com vestes coletivas, mas que, em realidade, é um mero cúmulo de inúmeras pretensões individuais (as chamadas ações pseudocoletivas) (cf. Ações coletivas cit., p. 120 e 200).

${ }_{132}$ TJSP, apelação com revisão $\mathrm{n}^{\mathrm{o}}$ 650.366-4/0-00, 6 $6^{\mathrm{a}}$ Câmara de Direito Privado, relator Des. Vito Guglielmi, julgamento em 27/08/2009.
} 
Por outro lado, um exemplo que envolve interesses individuas que se qualificam como homogêneos é a demanda pela qual se pretende obter o reconhecimento da sujeição de determinada instituição particular de ensino às regras do Decreto-Lei 3.200/1941, que prevê descontos nas mensalidades dos pais que tenham mais de um filho matriculado na mesma escola. A homogeneidade reside no fato de que o interesse de todos os pais com mais de um filho matriculado na mesma instituição de ensino não difere em nenhum aspecto ${ }^{133}$ e pode ser julgada macroscopicamente.

Aliás, quando se fala em dimensão coletiva prevalecendo sobre a individual, não se sugere que haja um número mínimo de interessados na tutela coletiva de seus direitos individuais homogêneos. Sob a égide do direito posto, não se sustentaria a exigência de um limite mínimo de vítimas (aqui tratadas a título amplo, como no artigo 17 do CDC), sob pena de obstaculizar o emprego dos mecanismos coletivos de tutela ${ }^{134}$.

Prosseguindo no exame da regra (b)(3) das Federal Rules, que pode ser transportada para a realidade brasileira, extrai-se a exigência da chamada superioridade da tutela coletiva. Trata-se de requisito que, em realidade, coincide com a condição da ação chamada interesse de agir (utilidade), ou seja, com a aptidão do provimento estatal na solução da crise jurídica submetida ao exame do Judiciário ${ }^{135}$.

\footnotetext{
${ }^{133}$ Assim já decidiu o STJ: REsp 184.986/SP, 4a Turma, rel. Min. João Otávio de Noronha, j. 17/11/2009. A propósito, o atendimento à condição de ser pai de mais de um filho matriculado na mesma instituição não interfere na procedibilidade da ação coletiva e na pretensão de condenação genérica ao pagamento dos danos causados, pois é questão afeta à liquidação e execução individuais da sentença genérica.

${ }^{134}$ Ocorre que outros obstáculos (às vezes não tão legítimos) existirão em desfavor do processo coletivo. Assim, por exemplo, determinada entidade de proteção dos interesses de consumidores poderá não se sentir suficientemente estimulada a intentar uma demanda coletiva para tutelar uma dúzia de indivíduos. Por sua vez, a legitimidade atribuída a órgãos públicos poderia superar esse impasse, já que atuam por dever de ofício e não são contidos por obstáculos econômicos ou psicológicos. Em se tratando do Ministério Público, porém, a situação não se resolve porque, a priori, não haveria relevância social, no entender daqueles que submetem a atuação do Ministério Público a essa condicionante. Restaria, então, o alento da legitimidade da Defensoria Pública, órgão que carece de consolidação e aperfeiçoamento infraestrutural em parte dos estados brasileiros. Mas, dado todo esse panorama, a realidade impõe um limite mínimo de titulares de direitos individuais homogêneos para o processamento da ação coletiva. Não alcançado esse limite, tornam-se factíveis apenas os processos individuais. Sob outra perspectiva, José Marcelo Menezes Vigliar afirma “jamais mencionei deva o número de interessados constituir o elemento essencial para o emprego de um outro sistema. O número reduzido pode - e isso é verdade - indicar que não se está diante de uma coletividade considerável que pode ser afetada pela prolação de decisões contraditórias sobre eventos absolutamente comuns a todos!" (cf. Interesses individuais homogêneos e seus aspectos polêmicos cit., pp. 23/24).

${ }^{135}$ Equivale a dizer que: "tendo embora o Estado o interesse no exercício da jurisdição (...), não lhe convém acionar o aparato judiciário sem que dessa atividade se possa extrair algum resultado útil. (...) O provimento, evidentemente, deve ser apto a corrigir o mal de que o autor se queixa, sob pena de não ter razão de ser" (Grinover et. al., Teoria geral do processo cit., p. 258). Ainda, citando lição de Comoglio, segundo Bedaque, a aferição do interesse de agir permite "a verificação da utilidade social da iniciativa judicial, só admissível para contribuir de forma real para a efetivação do direito e a pacificação social" (cf. Efetividade do Processo e Técnica Processual cit., p. 295).
} 
Então, sob esse ângulo, voltamos ao exemplo acima mencionado de busca de reparação dos segurados, via ação coletiva, por ato ilícito supostamente praticado pela seguradora. Uma vez não demonstrada a homogeneidade na conduta da seguradora, de nada adiantaria uma condenação genérica que reconhecesse a obrigação da seguradora em indenizar (an debeatur) se a cada segurado lesado ainda caberia o ônus de provar a ocorrência do ato ilícito em seu desfavor por ato da seguradora e a extensão do dano pessoal.

Por razões de economia, o sistema processual não admite a atuação inútil do Judiciário e, se constatado que a técnica da ação coletiva não dispensaria uma dilação probatória análoga àquela que seria produzida em uma demanda individual do interessado (dilação esta que deve ser ampla, em respeito ao contraditório e ampla defesa assegurados ao demandado), os direitos individuais, ainda que homogêneos, não merecerão tratamento molecular ${ }^{136}$.

Sendo assim, os interesses individuais homogêneos só serão aglutinados em juízo caso a via coletiva seja efetivamente útil aos respectivos titulares para a solução da crise jurídica e para a pacificação social. Aliás, alinham-se a essa proposição os ideais instrumentalistas do processo (do atendimento aos escopos da jurisdição, notadamente eliminação dos conflitos, e efetividade do processo), já que: “admitir ações civis públicas inidôneas para gerar provimentos jurisdicionais efetivamente úteis, só pode levar ao descrédito do instrumento, à frustração dos consumidores de justiça, ao desprestígio do Poder Judiciário" $" 137$.

\footnotetext{
${ }^{136}$ Para a análise detalhada de exemplos das cortes norte-americanas em que a certificação como ação coletiva (certification) foi negada por ausência de atendimento aos requisitos da prevalência das questões comuns ou da superioridade da tutela coletiva, v., por todos, Grinover, Da class action for damages à ação de classe brasileira: os requisitos de admissibilidade cit., pp. 17/20.

${ }^{137}$ Sobre a preocupação com a instrumentalidade substancial do processo, vide: Watanabe, Código Brasileiro de Defesa do Consumidor comentado cit., $9^{a}$ ed., p. 790, com referências à doutrina italiana contemporânea de Proto Pisani, Luigi Montesano e Nicola Picardi.
} 


\section{PARTE II - O PROCESSO COLETIVO PARA O TRATAMENTO DOS DIREITOS INDIVIDUAIS HOMOGÊNEOS NO ORDENAMENTO BRASILEIRO}

\section{Legitimação para agir}

\subsection{Natureza. Legitimação extraordinária}

O estudo da legitimação para agir no contexto aqui considerado assume excepcional importância ${ }^{138}$ porque define quem serão os porta-vozes em juízo dos direitos evidenciados pela sociedade contemporânea formadora de relações massificadas.

A par da coisa julgada, a legitimação é um dos grandes temas revisitados pelo modelo de processo e ponto sensível no estudo da tutela coletiva. Isso ocorre porque a legitimação de agir se localiza na porta de entrada do Judiciário, consistindo, portanto, em relevante mecanismo de controle (tanto ampliativo quanto restritivo) sobre os litígios judicializáveis.

O modelo de processo, sob a ótica individualista, concebe a legitimação para agir, em regra, segundo uma "relação entre o sujeito e a causa" ${ }^{139}$, ou, nas palavras de Alfredo Buzaid ${ }^{140}$, com influência na doutrina de Liebman ${ }^{141}$, na "pertinência subjetiva da

\footnotetext{
${ }^{138}$ Aliás, ao lado da importância teórica, o tema da legitimação é determinante na análise do desempenho da tutela coletiva no escopo de pacificação pois, como lembra Ada Pellegrini Grinover, na experiência norteamericana das class actions for damages, em mais de três décadas de aplicação das Federal Rules, foram poucas as ações admitidas e processadas (com obtenção de certification) como ações coletivas, por falta de atendimento aos threshold requirements (Da class action for damages à ação de classe brasileira: os requisitos de admissibilidade cit., p. 16).

${ }^{139}$ Cf. Dinamarco, Instituição de Direito Processual Civil cit., vol. II, p. 306. Ou, "da relação entre o sujeito e a relação jurídica" (cf. Wambier, Teresa Arruda Alvim, Nulidades do processo e da sentença, $6^{\mathrm{a}}$ ed., São Paulo, Revista dos Tribunais, 2007, p. 57). Na recente concepção de Susana Henriques da Costa, trata-se da "correspondência entre as posições de autor e réu na demanda e sujeito ativo e passivo na relação jurídica material” (cf. Condições da ação, São Paulo, Quartier Latin, 2005, p. 63). Para José Frederico Marques (Manual de Direito Processual Civil, vol. I, 10ª ed., São Paulo, Saraiva, 1983, p. 183), “Aquele que pede a tutela jurisdicional em relação a um litígio deve ser o titular da pretensão formulada ao Judiciário, e deve apresentá-la em face de quem é o sujeito passivo dessa mesma pretensão (...). Só os titulares dos interesses em conflito têm direito à prestação jurisdicional e ficam obrigados a subordinar-se, in casu, ao poder ou imperium estatal", com a ressalva da legitimação extraordinária (cit., p. 184). Ernane Fidélis dos Santos (Manual de Direito Processual Civil, vol. I, $5^{\text {a }}$ ed., São Paulo, Saraiva, 1997, p. 50) acentua que, na atual fase de desenvolvimento da ciência processual que preconiza a abstração e autonomia do direito de ação, "só terá legitimidade ativa para a ação, em princípio, apenas quem pleiteia direito próprio, ou, melhor dizendo, direito de que se julga portador, caso exista. A norma é de direito processual e apenas por coincidência é que pode haver identificação com o titular do direito material".

${ }^{140}$ Cf. Estudos de Direito, São Paulo, Saraiva, 1972, p. 89.

${ }^{141}$ Cf. Manual de Direito Processual Civil (trad. Cândido Rangel Dinamarco), $3^{\mathrm{a}}$ ed., vol. I, São Paulo, Malheiros, 2005, pp. 208/211, com particular ressalva à estreita ligação entre a legitimidade para agir e o interesse processual (ideia também cultivada por Cândido Rangel Dinamarco, cit., p. 308 e Salvatore Satta, Diritto Processuale Civile, Padova, Cedam, 1981, p. 83, com referência à giusta parte): “A titularidade da ação apresenta-se necessariamente como problema de duas faces: a da legitimidade ativa e a da legitimidade
} 
ação". Desse modo, parte legítima para a ação, tradicionalmente, é aquela que figura na relação jurídica de direito material, tal como afirmada, sobre a qual espraiarão os efeitos do comando estatal que se pretende produzir. Na doutrina processual, o assunto já foi explorado por renomados estudiosos ${ }^{142}$.

A legitimação para agir, como sabido e repetido por todos, é uma condição da ação, conforme taxou o Código de Processo Civil no artigo 267, inciso VI ${ }^{143}$. O preenchimento dessa condição, ressaltou Monacciani em 1951, lembrado mais tarde por Barbosa Moreira ${ }^{144}$, produz situações legitimantes, para a posição de ambas as partes, uma vez observado o modelo subjetivo abstrato definido pela lei em caráter ideal para a lide ${ }^{145}$. Por conseguinte, atendida essa condição, “as partes terão o direito de esperar que o processo (...), atinja desfecho normal e produza resultado útil, mediante o exercício pleno da função jurisdicional, a culminar na emissão de sentença definitiva, apta, com a formação da coisa julgada, a estabelecer em termos incontroversos a disciplina da situação jurídica litigiosa""146.

passiva; resolve-se na pertinência do interesse de agir ao autor na pertinência ao réu do interesse de defenderse" (cit., p. 210), e conclui, também com referência à abstração do direito de ação: "A legitimação para agir é, pois, em resumo, a pertinência subjetiva da ação, isto é, a identidade entre quem a propõe e aquele que, relativamente à lesão de um direito próprio (que afirma existente), poderá pretender para si o provimento de tutela jurisdicional pedido com referência àquele que foi chamado em juízo" (cit., p. 211).

${ }^{142}$ Vide por todos: Thereza Alvim, O direito processual de estar em juízo, São Paulo, Revista dos Tribunais, 1996, pp. 79/87 e Athos Gusmão Carneiro, Intervenção de terceiros, 16a ed., São Paulo, Saraiva, 2006, pp. 41/46, este último enfatizando que a legitimação ad causam se examina em tese a partir da "coincidência entre a pessoa do autor e a pessoa a quem, em tese, a lei atribui a titularidade da pretensão deduzida em juízo, e a coincidência entre a pessoa do réu e a pessoa contra quem, em tese, pode ser oposta tal pretensão" (op. cit., p. 41), e, para o autor, este é um dos grandes pontos de conexão entre o direito material e o direito processual na perspectiva instrumental do processo (op. cit., p. 44).

143 "Extingue-se o processo, sem resolução do mérito: (...) VI - quando não concorrer qualquer das condições da ação, como a possibilidade jurídica, a legitimidade das partes e o interesse processual".

${ }^{144}$ Barbosa Moreira, Apontamentos para um estudo sistemático da legitimação extraordinária, in Revista dos Tribunais, n. 404, 1969, pp. 9/18.

${ }^{145}$ Assim, Barbosa Moreira define a legitimação pela "coincidência entre a situação jurídica de uma pessoa, tal como resulta da postulação formulada perante o órgão judicial, e a situação legitimante prevista na lei para a posição processual que a essa pessoa se atribui ou que ela mesma pretende assumir" (Apontamentos cit., p. 9). Dentre os italianos, Elio Fazzallari observa que: "Chiamiamo situazione legittimante il punto di aggancio della legittimazione ad agire, fuor di metafora la situazione in base alla quale si determina qual'è il soggetto che, in concreto, può e deve compiere un certo atto, e situazione legittimata il potere, o la facoltà, o il dovere - o una serie dei medesimi - che, di conseguenza, viene a rispettare al soggetto individuato, val dire il contenuto della legittimazione, cio in cui essa consiste" (cf. Istituizioni di Diritto Processuale, $5^{\mathrm{a}}$ ed., Padova, Cedam, 1989, p. 289). Aproximando-se da ideia de situação legitimante, Miguel Teixeira de Sousa preferiu a noção de função concretizadora: "A legitimidade processual define as pessoas (singulares ou coletivas) e as entidades contra quem essas acções podem ou devem ser instauradas. Neste sentido, a legitimidade processual exerce uma função concretizadora: a legitimidade reporta-se às condições que definem que determina pessoa ou entidade pode ser parte activa numa acção ou pode ou deve ser parte passiva numa causa" (Cf. Legitimidade processual cit., p. 130).

${ }^{146}$ Cf. Barbosa Moreira, Apontamentos cit., p. 9. 
Nesse diapasão, o artigo $6^{\circ}$ do Código de Processo Civil brasileiro preconiza que "Ninguém poderá pleitear, em nome próprio direito alheio, salvo quando autorizado por lei”. Alternativamente, para as situações nas quais o titular do direito material debatido não figura na relação processual como parte, o sistema processual permite que alguém o represente em juízo, o que corresponde à exceção tratada na segunda parte do caput do artigo $6^{\circ}$ do Código de Processo Civil brasileiro.

Na primeira hipótese, em que é o próprio titular do direito material deduzido em juízo que ostenta a qualidade de parte legítima, convencionou-se falar em legitimidade ordinária.

Por sua vez, quando a lei autoriza, excepcionalmente, que um terceiro atue judicialmente, em nome próprio, em prol do verdadeiro titular da relação material, fala-se de legitimidade extraordinária ou substituição processual. Em outras palavras, a legitimidade extraordinária equivale a uma dissociação entre "o titular da lide" e "aquele que pode agir em juízo"147. Observação pouco lembrada, que vale aqui ser registrada, é a de que, quando se fala em atuação do legitimado extraordinário em nome próprio, como assevera Antônio Carlos de Araújo Cintra ${ }^{148}$, significa dizer que, a despeito de não ser titular da relação jurídica material, ele assume a posição de parte processual, com o respectivo complexo de poderes, direitos, obrigações e ônus que decorrem do processo ${ }^{149}$.

A legitimidade ordinária pode ser classificada nas categorias simples e concorrente. Simples equivale à situação na qual o sujeito, que se afirma titular do direito material ou contra o qual se pretende seja deferida a tutela jurisdicional, exerce o direito de ação ou de defesa isoladamente, sem a atuação de qualquer outro sujeito. De seu turno, a legitimidade ordinária concorrente se relaciona à hipótese em que essa atuação possa ou deva ocorrer em conjunto, porque a relação jurídica assume um esquema ligeiramente mais

\footnotetext{
${ }^{147}$ Cf. Thereza Alvim, cit., p. 83. Segundo Barbosa Moreira não há uma completa dissociação, pois "Esses casos [de legitimação extraordinária], que são excepcionais, fundam-se quase sempre na existência de um vínculo entre as duas situações, considerado suficientemente intenso, pelo legislador, para justificar o fato de autorizar-se a alguém que nem sequer se afirma titular da 'res in iudicium deducta', a exigir do juiz um pronunciamento sobre direito ou estado alheio" (cf. Apontamentos cit., p. 10). A atuação do legitimado, seja ordinário ou extraordinário, segundo Athos Gusmão Carneiro, se justifica na vinculação entre a parte e o objeto da causa (op. cit., p. 45). Essa vinculação Antônio Carlos de Araújo Cintra chamou de interesse material secundário (Estudo sobre a substituição processual no direito brasileiro, in Revista dos Tribunais, ano 61, v. 438, abril de 1972, p. 26).

${ }^{148}$ Op. cit., p. 29.

149 Ressalva feita, tradicionalmente, aos poderes de disposição dos direitos controvertidos, que são a confissão, a renúncia, a transação, a desistência da ação ou o reconhecimento do pedido (Cintra, op. cit., p. 30 e Edson Ferreira da Silva, Da legitimação extraordinária, inclusive na Constituição de 1988, in Revista de Processo, v.16, n. 64, outubro a dezembro de 1991, pp. 80/91, notadamente, p. 84).
} 
complexo $^{150}$, com a formação de litisconsórcio, facultativo ou necessário, respectivamente, quando a cumulação subjetiva se der por razões de conveniência (artigo 46 do Código de Processo Civil brasileiro) ou em função da unitariedade da relação jurídica em debate ou por disposição expressa de lei (artigo 47).

A chamada legitimação extraordinária também foi alvo de atentas observações dos alemães e dos italianos. Na Alemanha, os primeiros estudos sobre o assunto são atribuídos a Adolf Wach e Köhler. Na Itália, foi Chiovenda quem, em 1906, cunhou o instituto de sostituzione processuale, seguido por Galgano ${ }^{151}$, que se dedicou ao tema em específica monografia (Sulla dottrina della sostituzione processuale). E ganhou, finalmente, uma classificação pormenorizada. Sobre esse assunto, de grande notoriedade é a construção teórica de Barbosa Moreira, na qual em boa medida nos concentraremos neste trabalho, sob pena de extrapolar os limites da investigação aqui proposta.

Para o autor, fala-se de legitimação extraordinária autônoma, quando o legitimado extraordinário atua em juízo independentemente do titular do direito material. $\mathrm{Na}$ hipótese de a lei reservar a situação legitimante de modo exclusivo ao legitimado extraordinário, não se descartando a intervenção do legitimado ordinário na qualidade de assistente, trata-se de legitimação extraordinária exclusiva ${ }^{152}$, como ocorria, na legislação revogada, com o processo ajuizado pelo marido (parte principal) tendo por objeto bem dotal da esposa (parte acessória).

Quando, diferentemente, a atuação do legitimado extraordinário não interferir e puder conviver com a situação legitimante ordinária, ter-se-á a legitimação extraordinária concorrente ${ }^{153}$.

\footnotetext{
${ }^{150}$ Watanabe, Tutela jurisdicional dos interesses difusos: a legitimação para agir, in A tutela dos interesses difusos (coord. Ada Pellegrini Grinover), São Paulo, Max Limonad, 1984, p. 86, segundo quem: "Na concepção tradicional, a ideia de interesse ou direito está sempre ligada a de respectivo titular. (...) Podem, também, assumir um esquema mais complexo, onde, como bem anota Barbosa Moreira, o interesse 'pode ser comum a um grupo mais ou menos vasto de pessoas, em razão de vínculo jurídico que as une a todas entre si, sem no entanto situar-se no próprio conteúdo da relação plurissubjetiva'. Mesmo sendo bastante amplo o grupo de pessoas há, ainda aí, sempre a possibilidade de individuação de seus componentes, ligados por uma relação-base (sociedade-condomínio)".

${ }^{151}$ Cintra, Estudo cit., p. 23.

${ }^{152}$ Esta sim verdadeira substituição processual, no rigor técnico, segundo Barbosa Moreira, com escol na doutrina de Carnelutti (Apontamentos cit., p. 12), mas, acatando a tradição pelo uso da expressão substituição processual, cunhada por Chiovenda, para todas as modalidades de legitimação extraordinária. Na Itália, Antônio Carlos Araújo Cintra noticia que a expressão foi combatida por Redenti, Galanti, Segni e Satta (op. cit., pp. 23/24).

${ }^{153}$ A legitimação extraordinária concorrente ainda se desdobra em duas categorias, Para ilustrá-las, Barbosa Moreira se valeu de exemplos até então factíveis: o pedido de anulação de casamento ajuizado pelo Ministério Público, nos termos do artigo 206 e seguintes do Código Civil de 1916 (legitimação extraordinária
} 
De outro lado, há legitimação extraordinária subordinada se a situação legitimante pressupõe necessariamente a atuação do legitimado ordinário e faculta a intervenção do legitimado extraordinário no processo, na condição de assistente litisconsorcial. Frise-se que, em qualquer hipótese, a atuação do legitimado extraordinário independente de autorização do legitimado ordinário ${ }^{154}$.

Finalmente, a legitimação extraordinária diferencia-se do instituto da representação, pois o representante age em nome e no interesse do representado, e nem chega a assumir a qualidade de parte do processo que envolve direito do representado ${ }^{155}$. A figura da representação existe na atuação do genitor em nome e no interesse do menor totalmente incapaz ou, na chamada representação orgânica, na atuação dos órgãos de pessoas jurídicas, situação na qual a pessoa do representante (ou presentante, como prefere Pontes de Miranda ${ }^{156}$ ) supre a impossibilidade material de prática de atos pela pessoa jurídica representada (ou presentada).

Nesse quadro, analisando o elenco de legitimados para a defesa de interesses individuais homogêneos disposto no art. 82 do CDC, a legitimidade atribuída a esses sujeitos é notoriamente extraordinária. Isso porque nenhum dos legitimados ali mencionados ostenta a qualidade de titular do direito individual tratado na dimensão coletiva.

Qualquer esforço da lei no sentido de autorizar aos legitimados ordinários a defesa dos interesses individuais homogêneos em juízo seria inócuo, pois coincidiria com o papel já desempenhado pelo litisconsórcio ativo facultativo no processo de cunho individualista. Ou seja, na defesa dos interesses individuais homogêneos em sua dimensão coletiva, para nós a imputação de legitimação extraordinária é incontornável ${ }^{157}$.

concorrente primária) e o pedido dos acionistas de ressarcimento da sociedade pelos prejuízos causados por atos dos administradores, iniciativa que só pode se implementar caso a sociedade mesma permaneça inerte, conforme então dispunha o art. 123 do Decreto-lei 2.627/1940 (legitimação extraordinária concorrente subsidiária) (Apontamentos cit., p. 11).

${ }^{154}$ Conforme acentua Antônio Carlos de Araújo Cintra, “o verdadeiro substituto processual, como já vimos, independe de autorização do substituído, podendo agir em juízo independentemente e até contra a vontade deste" (Estudo cit., p. 29).

${ }^{155}$ Edson Ferreira da Silva, op. cit., pp. 81/82.

${ }^{156}$ Tratado de Direito Privado, vol. III, $3^{\text {a }}$ ed., Borsoi, Rio de Janeiro, 1970, p. 233.

157 Nesse sentido, Ada Pellegrini Grinover adverte: "A legitimação ativa, concorrente e disjuntiva, é atribuída, pelo dispositivo em foco, aos entes e pessoas indicadas no art. 82. Aqui se trata inquestionavelmente de legitimação extraordinária, a título de substituição processual. Não só porque assim o afirma o legislador, quando expressamente se refere ao litigar, em nome próprio e no interesse das vítimas ou seus sucessores, mas ainda porque, na hipótese, os legitimados à ação não vão a juízo em defesa de seus interesses institucionais, como pode ocorrer nas ações em defesa de interesses difusos ou coletivos" (cf. 
Ainda que se pense na hipótese da entidade associativa, que inclua no rol de seus objetivos institucionais a defesa, por exemplo, do interesse coletivo dos consumidores, entendemos que se trata de hipótese de legitimação extraordinária. Isso porque, previsão estatutária de tal ordem não altera a titularidade do direito articulado em juízo.

A entidade associativa não agrega a posição de titular do direito tratado coletivamente com a simples inclusão da defesa dos direitos transindividuais em seus fins institucionais; o interesse na defesa dos direitos coletivos não se confunde com a sua titularidade. Dessa forma, ela pode ostentar, no máximo, a qualidade de co-titular (quando, além de representante, é membro do grupo, na posição de consumidora de produto nocivo, por exemplo), mas a sua posição em juízo, para se valer da faculdade de atuar como autor coletivo (com os consectários legais daí decorrentes), será sempre de legitimado extraordinário $^{158}$.

Neste ponto, portanto, a respeito da natureza da legitimação das entidades associativas que atuam em nome de direitos difusos e coletivos, ousamos discordar de Ada Pellegrini Grinover ${ }^{159}$, Kazuo Watanabe ${ }^{160}$, Rodolfo de Camargo Mancuso ${ }^{161}$ e Vincenzo Vigoriti ${ }^{162}$, que preconizam se tratar de hipótese de legitimação ordinária.

Código Brasileiro de Defesa do Consumidor comentado pelos autores do anteprojeto, $10^{\mathrm{a}}$ ed., vol. II, Rio de Janeiro, Forense, 2011, p. 138).

${ }^{158}$ Nelson Nery Júnior e Rosa Maria de Andrade Nery observam que: "Na defesa dos direitos difusos e coletivos por ação civil pública ou ação coletiva a associação civil age como legitimada autônoma para a condução do processo, isto é, legitimada ordinária para a causa; quando defende direitos individuais homogêneos ou direitos individuais de seus associados é substituta processual" (cf. Código de Processo Civil Comentado e legislação extravagante, $11^{\mathrm{a}}$ ed., São Paulo, Revista dos Tribunais, 2010, p. 192). Ainda, vide Pedro Lenza, Teoria geral da ação civil pública cit., $3^{\mathrm{a}}$ ed., pp. 173/180, com farta referência doutrinária.

159 Cf. Código Brasileiro de Defesa do Consumidor comentado pelos autores do anteprojeto cit., p. 176; Ações coletivas para a tutela do meio ambiente e dos consumidores, in Novas Tendências do Direito Processual Civil, Rio de Janeiro, Forense Universitária, 1990, p. 154, e Novas tendências na tutela jurisdicional dos interesses difusos, in O processo em sua unidade II, Rio de Janeiro, Forense, 1984, p. 107, neste último trabalho deixando claro que a ideia foi edificada quando a lei ainda negava legitimidade às associações: "recentemente, têm sido apontados entre nós novos caminhos que permitiriam às associações agirem em juízo para a tutela de seus associados, a título de legitimação ordinária, na medida em que tais interesses se confundiriam com os próprios interesses institucionais da associação".

${ }^{160}$ Tutela jurisdicional dos interesses difusos: a legitimação para agir cit., pp. 90/96. Neste texto, datado de 1984, há uma nítida tentativa de justificar a atuação das associações no estado legislativo de então, quando a regra do art. $6^{\circ}$ do CPC não havia sido ainda excepcionada pelas supervenientes Leis 7347/85 e 8078/90.

${ }^{161}$ Ação civil pública, $12^{\mathrm{a}}$ ed., São Paulo, Revista dos Tribunais, 2011, p. 158.

${ }^{162}$ Interessi collettivi e processo cit., pp. 145 e seguintes e 273/274, em que o autor comenta a legitimidade dos membros do grupo para a propositura de class actions na common law norte-americana, que possui, como se sabe, regramento diverso da realidade brasileira. Já se disse acima que a associação até pode compor o grupo titular do direito coletivo, mas a sua condição de legitimada não tem origem nessa circunstância, mas sim na sua eleição como porta voz dos interesses do grupo. Em outras palavras, a legitimação é conferida à associação enquanto agremiação da sociedade civil voltada à defesa de dado interesse coletivo, e não enquanto membro do grupo, daí a sua natureza extraordinária. Aliás, Vigoriti qualificou essa modalidade de 
Com toda vênia, parece-nos que a construção teórica em torno da legitimação ordinária das associações civis se justificava de lege lata, quando os únicos veículos de direitos coletivos eram então a ação popular e a ação em defesa do meio ambiente titularizada pelo Ministério Público, como propunha Barbosa Moreira: "De lege lata, será possível, em determinados casos, contornar o óbice do art. $6^{\circ}$ do Código de Processo Civil, desde que se reconheça que neles o que se põe em julgo é algo distinto da mera soma dos interesses individuais: um interesse geral da coletividade, qualitativamente diverso e capaz de merecer tutela como tal. Desse interesse pode uma associação fazer-se titular, ela mesma, não como simples representante dos respectivos membros, nem como intérprete, em nome próprio, das pretensões paralelas de cada um deles. A associação se legitimaria, pois, em caráter ordinário" ${ }^{\text {"163. }}$

Com efeito, consoante escreve Rodolfo de Camargo Mancuso, "o critério legitimante, em tema de interesses metaindividuais, não repousa na sua titularidade, e sim na idoneidade social de seu portador" ${ }^{\prime 164}$. Por isso, o fato de associação civil ser ou não também titular do interesse em jogo não é a situação legitimante; situação legitimante é, como afirma Mancuso, a sua idoneidade e representatividade social.

Anuímos com Ricardo de Barros Lionel quando sustenta que "as próprias associações não são titulares exclusivas de tais interesses, pois estão defendendo posições jurídicas alheias, de uma coletividade indeterminada e indeterminável"165, embora o autor compartilhe da tese da legitimação autônoma das associações civis na defesa de direitos difusos e coletivos. Também se acrescente, como lembra Eurico Ferraresi ${ }^{166}$, que o esquema da legitimação ordinária não explica adequadamente a extensão da coisa julgada a terceiros que não participaram do processo.

Firmado se tratar de legitimação extraordinária, é simples inferir a sua natureza autônoma e exclusiva. Autônoma porque é dispensável a presença no processo

legitimação como ordinária sui generis, com contornos que, na verdade, mais parecem se aproximar da legitimação extraordinária.

${ }^{163}$ Cf. Tutela jurisdicional dos interesses coletivos e difusos cit., p. 203.

${ }^{164}$ Cf. Ação civil pública, $12^{\mathrm{a}}$ ed., São Paulo, Revista dos Tribunais, 2011, p. 117 (nota de rodapé n. 11).

${ }^{165}$ Cf. Manual do Processo Coletivo, $2^{\mathrm{a}}$ ed., São Paulo, Revista dos Tribunais, 2011, p. 152.

${ }^{166}$ Ação popular, ação civil pública e mandado de segurança coletivo cit., p.109. A esse respeito, destacando também a situação do Ministério Público em prol de interesses coletivos e difusos, em que não defende direito próprio, vide Teori Albino Zavascki, Processo coletivo cit., pp. 139 e 152/153. 
coletivo do suposto legitimado ordinário ${ }^{167} \mathrm{e}$, mais, exclusiva porque foi tolhida do legitimado ordinário a iniciativa para a propositura da demanda coletiva.

\subsection{Legitimação exclusiva. A questão da ilegitimidade coletiva do membro do grupo}

No particular tratamento coletivo dos direitos individuais homogêneos, é notório $^{168}$ que o sistema preferiu negar legitimidade ativa aos consumidores individualmente considerados, em opção contrária à do modelo norte-americano das class action $^{169}$ que serviu de inspiração ao legislador brasileiro.

A distinção se justifica, pois nas ações coletivas dos países da civil law, os obstáculos psicológicos e econômicos sobrepõem-se às vantagens obtidas pela atuação em sede coletiva, como bem apontado por Cappelletti: "O dano a ele pessoalmente advindo será, normalmente, muito exíguo para encorajá-lo a agir contra um assim potente adversário" ${ }^{170}$. No sistema das class action, diversamente, essa barreira é mínima pois há sólidos estímulos econômicos, como gratificação financeira ao autor e remuneração substancial ao advogado em caso de êxito do grupo.

É verdade que, no caso brasileiro, há regra dispensando o adiantamento de todos os custos e despesas do processo bem como eximindo o autor da sucumbência, caso

\footnotetext{
${ }^{167}$ Para Antonio Gidi, o fato de ser autorizado ao substituído ir a juízo individualmente permite que se fale em legitimação anômala (Coisa julgada e litispendência em ações coletivas cit., p. 44).

${ }^{168}$ Fala-se de notoriedade em razão de um fenômeno, na seara dos direitos difusos, que não se repete no contexto dos interesses individuais homogêneos. É comum o debate sobre certa sobreposição do objeto de ação popular e de ação civil pública, permitindo que, via ação popular, o cidadão comum possa zelar, por exemplo, pelo meio ambiente (direito difuso) o que, no regime da Lei 7347/85, não é possível. Sobre o tema, vide: Eurico Ferraresi, Ação popular, ação civil pública e mandado de segurança coletivo cit., pp. 296/300.

${ }^{169}$ Conforme item (a) da Rule 23 que estabelece: "Prerequisites. One or more members of a class may sue or be sued as representative parties on behalf of all members only if: (...)".

${ }^{170} \mathrm{Cf}$. Formações sociais e interesses coletivos diante da justiça civil cit., pp. 136/137, que lançou mão de imagem muito ilustrativa da desvantagem econômica do indivíduo isolado frente ao agente violador em massa: "O consumidor isolado, sozinho, não age; se o faz, é um herói; no entanto, se é legitimado a agir não meramente para si, mas pelo grupo inteiro do qual é membro, tal herói será subtraído ao ridículo destinado de Dom Quixote, em vã e patética luta contra o moinho de vento". Ilustração semelhante é feita por Barbosa Moreira, que equipara o consumidor singular a um guerreiro desarmado frente ao gigante Davi (cf. $A$ proteção jurídica dos interesses coletivos, in Temas de direito processual - terceira série, São Paulo, Saraiva, 1984, p. 177). Ada Pellegrini Grinover lembra também que a pessoa física "pode até ignorar seus direitos, por tratar-se de campo novo e praticamente desconhecido; sua pretensão individual pode, ainda, ser por demais limitada; e as custas do processo podem ser desproporcionais a seu prejuízo econômico. Não se pode olvidar, de outro lado, o aspecto psicológico de quem se sente desarmado e em condições de inferioridade perante adversários poderosos, cujas retorções pode temer; nem se pode deixar de lado a preocupação para com possível transações econômicas, inoportunas exatamente na medida em que o conflito é "pseudoindividual, envolvendo interesses de grupos e categorias" (cf. Novas tendências na tutela jurisdicional dos interesses difusos cit., p. 93).
} 
seja vencido (art. 83 do $\mathrm{CDC}^{171}$ ), mas não há qualquer outro incentivo que atue tão intensamente sobre a disposição dos titulares individuais na proposição coletiva.

Já as razões políticas que levaram a negar legitimidade ao membro singular do grupo são outras. Proto Pisani, lembrado por Barbosa Moreira ${ }^{172}$ e Ada Pellegrini Grinover ${ }^{173}$, mencionara o risco de colusão entre um dos co-legitimados e o agente público, caso o processo fosse conduzido negligentemente com o fim de beneficiar o ato lesivo.

Por outro lado, também se reconhece que o legislador brasileiro, na experiência da ação popular, lançou mãos de mecanismos para atenuar esse risco, quais sejam: possibilidade de litisconsórcio formado com outro(s) cidadão(s), intervenção obrigatória do Ministério Público, a quem compete promover diligências probatórias e assumir o polo ativo da ação em caso de desistência e, finalmente, a recorribilidade da sentença de improcedência por qualquer cidadão e pelo Ministério Público, tudo a teor dos arts. $6^{\circ}, \S 3^{\circ}$ e $4^{\circ}, 9^{\circ}$ e 19 da Lei n. 4717/65. Mais um importante mecanismo de eliminação dos objetivos espúrios das ações coletivas, como se verá adiante (infra, capítulo 4.2.1), é a ausência de coisa julgada em caso de improcedência por insuficiência de provas e, no caso específico dos direitos individuais homogêneos, o transporte in utilibus da coisa julgada para a esfera dos interessados individuais ${ }^{174}$.

De seu lado, outra ordem de razões influenciou o legislador ao negar a legitimação individual para a ação coletiva. Kazuo Watanabe esclareceu a intenção de evitar o manejo de ações coletivas por motivos exclusivamente políticos e egoísticos e a espera pela organização e educação da sociedade civil brasileira a fim de se formar uma sólida consciência coletiva ${ }^{175}$.

Mas em texto aparentemente mais recente, e reconhecendo a tendência Ibero-americana da legitimação da pessoa física (art. $3^{\circ}$, I e II $^{176}$, do Código Modelo de

171 “Art. 87. Nas ações coletivas de que trata este código não haverá adiantamento de custas, emolumentos, honorários periciais e quaisquer outras despesas, nem condenação da associação autora, salvo comprovada má-fé, em honorários de advogados, custas e despesas processuais. Parágrafo único. Em caso de litigância de má-fé, a associação autora e os diretores responsáveis pela propositura da ação serão solidariamente condenados em honorários advocatícios e ao décuplo das custas, sem prejuízo da responsabilidade por perdas e danos".

${ }^{172}$ A ação popular no direito brasileiro como instrumento cit., 12.

${ }^{173}$ Novas tendências na tutela jurisdicional dos interesses difusos cit., p. 99.

${ }^{174}$ Gidi, Coisa julgada e litispendência em ações coletivas cit., p. 36.

${ }^{175}$ Watanabe, Código Brasileiro de Defesa do Consumidor cit., 10ª ed., pp. 84/86.

176 “Art. $3^{\circ}$ : São legitimados concorrentemente à ação coletiva: I - o cidadão, para a defesa dos interesses ou direitos difusos de que seja titular um grupo, categoria ou classe de pessoas ligadas por circunstâncias de fato; II - o membro do grupo, categoria ou classe, para a defesa dos interesses ou direitos difusos de que seja 
Processos Coletivos para Ibero-América), o mesmo autor chega a comentar que "talvez estejamos em condições de repensar a legitimação da pessoa física às ações coletivas, sobretudo quando acoplada à aferição, pelo juiz, da 'representatividade adequada", 177 .

Além do exemplo dos países ibero-americanos, a Itália vem experimentando evolução legislativa mais acentuada no sentido de ampliar a legitimação para as ações coletivas em defesa dos interesses individuais homogêneos: se em 1998 foi outorgada legitimidade ativa às associações de consumidores pela Lei 281, já em 2009, o indivíduo componente da classe foi agraciado da titularidade da ação coletiva, pela Lei italiana 99 (que alterou a redação do art. 140-bis do Codice del Consumo).

De fato, o povo brasileiro não tem acentuada propensão associativa, como alertou Barbosa Moreira ${ }^{178}$, situação que, contudo, vem se alterando, ainda que timidamente, quando nos deparamos com o surgimento de considerável número de associações de moradores de bairros, de busca e defesa de crianças desaparecidas (p.ex.: Associação Brasileira de Busca e Defesa a Crianças Desaparecidas, mais conhecida como Mães da Sé), de ajuda a deficientes físicos (p. ex.: Associação de Assistência à Criança Deficiente $-A A C D)$, que ocupam posição de atores sociais com grande capacidade de diálogo com os órgãos de poder e com a comunidade.

Esse panorama nos permite dizer que o solidarismo - ideal que rege qualquer cidadão disposto a se associar para a perseguição de um objetivo de um grupo já está se fortificando na mentalidade no povo brasileiro. Mas, na nossa opinião, isso não basta, por ora, para que o consumidor individual possa demandar por todo o grupo.

Não desconhecemos as reflexões daqueles que preconizam maior participação popular na gestão dos interesses transindividuais ${ }^{179}$, desvinculação entre esse

titular grupo, categoria ou classe de pessoas ligadas entre si ou com a parte contrária por uma relação jurídica base e para a defesa de interesses ou direitos individuais homogêneos (...)".

${ }^{177}$ Cf. Watanabe, Código Brasileiro de Defesa do Consumidor cit., $10^{\mathrm{a}}$ ed., p. 64.

${ }^{178}$ Cf. La iniciativa en la defensa judicial de los intereses difusos y colectivos (un aspecto de la experiencia brasileña), Revista de Processo, n. 68, ano 17, outubro a dezembro de 1992, pp. 55/58, notadamente p. 57. Mancuso também descreveu que: "o processo de conscientização da coletividade pelo exercício da cidadania é mesmo lento e gradual, de sorte que impende dar tempo ao tempo, até que os cidadãos, isoladamente ou em grupo, estejam imbuídos de que podem e mesmo devem participar da gestão da coisa pública também mediante a judicialização dos conflitos metaindividuais" (cf. Ação civil pública cit., 12ª ed., p. 119).

${ }^{179}$ Cf. Hely Lopes Meirelles, Mandado de segurança, $28^{\mathrm{a}}$ ed., São Paulo, Malheiros, 2005, p. 132; José Afonso da Silva, Ação popular constitucional, $2^{\mathrm{a}}$ ed., São Paulo, Malheiros, 2007, p. 155; Mancuso, Ação popular, $5^{\mathrm{a}}$ ed., São Paulo, Revista dos Tribunais, 2003, pp. 153/154. 
instrumento democrático e os jogos políticos oportunistas ${ }^{180}$ e a ampliação "máxima [d]a porta de acesso desses interesses a justiça" ${ }^{" 181}$.

Contudo, não nos parece que o sistema processual coletivo brasileiro, nos moldes atuais, esteja apto a oferecer sólida legitimação ao consumidor singular e, em via de mão dupla, fórmula segura de representação dos interesses dos ausentes.

Examinando os contornos da ação popular portuguesa, Ada Pellegrini Grinover ${ }^{182}$ afirmou que: "Exatamente por não ter adotado o critério da representatividade adequada, o legislador brasileiro, na esteira do comando constitucional, só abriu ao cidadão a legitimação para a ação popular, em que tradicionalmente este exerce um direito de participação democrática ao defender em juízo interesses ligados ao patrimônio (lato sensu) estatal e à moralidade administrativa”.

Também nesse sentido, Álvaro Luiz Valery Mirra sustenta que, diante do caráter eminentemente participativo da tutela ao meio ambiente, não há como tolher do cidadão legitimidade ativa; mas, prossegue o autor dizendo que se essa participação é expressão originária do poder, não há espaço para um controle sobre a representatividade adequada dos interesses da coletividade ${ }^{183}$.

Trazidas essas lições para o contexto do processo coletivo envolvendo direitos individuais homogêneos, em que a democracia (escopo político do processo) é razão mediata de sua existência, enquanto a razão imediata é a solução das controvérsias

\footnotetext{
${ }^{180}$ Neste aspecto, Eurico Ferraresi afirma: "Não se pode ser ingênuo e imaginar que apenas iniciativas altruístas legitimariam as ações coletivas. Exige-se, sim, que se descreva uma situação merecedora de proteção. E isso já é mais que suficiente para se reconhecer a importância da legitimidade popular" (Ação popular, ação civil pública e mandado de segurança coletiva cit., p. 263). Ideia semelhante pode ser encontrada no seguinte acórdão do Supremo Tribunal de Justiça português, datado de 20 de outubro de 2005: "2. A acção popular cível é meio idóneo para providenciar à tutela do referido interesse, pois esta tanto comporta a defesa dos interesses difusos, como ainda dos chamados interesses individuais homogéneos. 3. Porquanto esta confere aos cidadãos um alargamento da legitimidade activa, a qual é independente da sua relação com o bem ou interesse especifico na causa. 4. Por conseguinte, o facto dos autores terem interesse pessoal e directo na declaração de integração da parcela de terreno, respeitante ao troço de estrada municipal, no domínio público autárquico, não descarta o recurso a essa especial providência" (Recurso de revista $\mathrm{n}^{\circ}$ 05B2578).

${ }^{181}$ Cf. Salles, Políticas públicas e a legitimidade para defesa de interesses difusos e coletivos, in Revista de Processo, vol. 30, n. 121, março de 2005, p. 50.

${ }^{182}$ Cf. Ação popular portuguesa: uma análise comparativa, in Revista de Processo, vol. 21, n. 83, julho de 1996, pp. 167/168. Assim também é o posicionamento de Suzana Henriques da Costa, para quem: "o direito de participação e fiscalização do cidadão é justamente o que lhe confere representatividade adequada" (cf. $O$ processo coletivo na tutela do patrimônio público e da moralidade administrativa cit., p. 204).

${ }^{183}$ Cf. Participação, processo civil e defesa do meio ambiente brasileiro, vol. I da tese de doutorado apresentada perante a Faculdade de Direito da Universidade de São Paulo, 2010, pp. 192/193 e 206.
} 
do modo mais eficiente (escopo social do processo), não podemos concordar com a outorga de legitimação ao consumidor singular sem um controle da representatividade ${ }^{184}$.

Essa conclusão pode ate ser contraposta com a ideia de que o remédio para o impasse seria o filtro da idoneidade do membro individual do grupo para a condução do processo coletivo. Mas a solução parece voltar ao cerne do problema: restrição da participação do indivíduo.

Devemos lembrar o sábio ensinamento de Carlos Alberto de Salles, para quem em um "novo modelo não basta estar aberta a porta da legitimidade, ainda que da maneira mais ampla possível, mas são necessários meios processuais especialmente arranjados para se atingir o objetivo de defesa dos interesses de natureza coletiva”, afinal, “O problema do acesso à justiça está relacionado com os custos envolvidos em qualquer iniciativa judicial, trazendo evidentes consequências à disposição dos agentes em promoverem a defesa de interesses gerais" ${ }^{\prime 185}$.

Para nós, impor ao membro do grupo pré-requisitos semelhantes aos exigidos dos entes intermediários para a atuação na esfera coletiva inviabiliza a sua iniciativa processual, já que não são suficientemente removidos os já tratados empecilhos para o acesso à justiça. Como resultado, essa modalidade de legitimação ainda incentivaria os free-riders ${ }^{186}$ a se beneficiarem da disposição de outros legitimados.

Então, nesse tema, aquiescemos com a corrente doutrinária que restringe a outorga de legitimidade ativa ao membro singular do grupo para a defesa de interesses coletivos.

\subsection{Legitimação concorrente e disjuntiva: a escolha pelo modelo misto proposto por Cappelletti}

\footnotetext{
${ }^{184}$ Posição semelhante é a do autor português Mário Frota, segundo o qual: “acção popular não é o molde mais adaptado em ordem à consecução da tutela de interesses e direitos do consumidor, antes prevalecendo em domínios outros, como os da preservação do ambiente ou da salvaguarda do património cultural" (cf. Por um código de processo colectivo em Portugal, in Revista Jurídica do Ministério Público do Estado de Minas Gerais, Belo Horizonte, n. 14, janeiro a junho de 2010, p. 3).

${ }^{185}$ Cf. Políticas públicas e a legitimidade para defesa de interesses difusos e coletivos cit., pp. 40/41. Em outra passagem do mesmo texto, o autor afirma: "Na solução da questão da representação acima discutida, o sistema brasileiro optou por privilegiar o critério da seletividade, em prejuízo do acesso irrestrito à justiça. Note-se que este critério não é numérico, mas qualitativo, ou seja, não foi motivado pela quantidade de causas levadas ao Judiciário, mas pela maneira como elas são conduzidas em juízo. Sem dúvida, a exclusão da iniciativa individual em defesa de interesses transindividuais 'atendeu a um propósito de possibilitar um melhor controle quanto à idoneidade e seriedade na propositura das ações civis públicas” (op. cit., p. 48).

186 Expressão trazida para o estudo das ações coletivas no Brasil por Carlos Alberto de Salles, Políticas públicas cit., p. 43.
} 
É célebre a reflexão de Cappelletti sobre as soluções práticas para o acesso à justiça na defesa dos interesses transindividuais. Nesse estudo, o autor identificou duas frentes de combate ao problema do acesso à justiça, indicando a ação governamental ${ }^{187}$ (pela qual órgãos públicos se encarregam de levar os interesses coletivos ao Judiciário) e as técnicas do private attorney general (ações coletivas movidas por indivíduos) ou do organizational private attorney general (ações coletivas por associações).

Como já previra Cappelletti, o mais eficaz meio de solução do problema da representatividade dos interesses coletivos em juízo são "as soluções compostas, articuladas flexíveis, por si só capazes de dar uma adequada resposta a um problema assim complexo como é aquele da tutela jurídica dos novos, emergentes e vitais interesses coletivos" $" 188$.

Em outras palavras, Cappelletti sugeriu uma combinação entre o controle público e a iniciativa privada para a defesa dos interesses transindividuais. O modelo misto foi recepcionado pelo legislador brasileiro, quando elencou os entes legitimados já na redação original do art. $5^{\circ}$ da Lei 7.347/85 e também no art. 82 do CDC, e foi aplaudido em peso pela doutrina ${ }^{189}$. Tal solução influenciou inclusive o Código Modelo para os países ibero-americanos.

Fala-se em legitimação concorrente não porque o legitimado ordinário esteja concorrendo na titularidade da ação coletiva com legitimado extraordinário, mas porque todos os entes legitimados extraordinários podem atuar independentemente dos demais, dispensando-se autorização do substituto ${ }^{190}$; é uma legitimação independente e autônoma ${ }^{191}$ e que autoriza a formação de litisconsórcio ativo facultativo entre os demais legitimados ou os interessados (art. 94 do CDC).

\footnotetext{
187 Desempenhada insuficientemente pelo Ministério Público italiano e francês, como narra Cappelletti (Formações sociais e interesses coletivos diante da justiça civil cit., p. 137/139), porque sujeitos a pressões políticas, denotaram passividade e falta de especialização e aparelhamento na defesa dos interesses coletivos. 188 Cf. Formações cit., p. 143.

189 Barbosa Moreira, La iniciativa en la defensa judicial de los intereses difusos y colectivos cit., p. 68; Mancuso, Ação civil pública cit., $12^{\mathrm{a}}$ ed., pp. 117/118; Venturi, Comentários ao Código Modelo de Processos Coletivos cit., p. 71; Leonel, Manual do processo coletivo cit., p. 148; Lenza, Teoria geral cit., $3^{\mathrm{a}}$ ed., p. 166; Gidi, Standing to sue in class actions (Legitimación para demandar en las acciones colectivas) cit., p. 108.

${ }^{190}$ A dispensa de autorização dos substitutos já é assente na jurisprudência dos tribunais superiores: RMS 14.849/SP, Rel. Min. Jorge Scartezzini, $5^{\mathrm{a}}$ Turma, j. 17/06/2003; MS 7.414/DF, Rel. Min. Gilson Dipp, $3^{\mathrm{a}}$ Seção, j. 14/05/2003; REsp 184.986/SP, Rel. Min. Luis Felipe Salomão, 4 a Turma, j. 17/11/2009; EREsp 847.034/RS, Rel. Min. Napoleão Nunes Maia Filho, $3^{\text {a }}$ Seção, j. 25/08/2010; EREsp 1103434/RS, Rel. Min. Francisco Falcão, Corte Especial, j. 01/08/2011; RE 210029, Rel. Min. Carlos Velloso, Pleno, j. 12/06/2006; e Súmula 629 do STF: "A impetração de mandado de segurança coletivo por entidade de classe em favor dos associados independe da autorização destes".

${ }^{191}$ Grinover, Os processos coletivos nos países de civil law e common law cit., $2^{\mathrm{a}}$ ed., p. 234.
} 


\subsection{Entes legitimados}

\subsubsection{Defensoria Pública}

A obrigação do Estado de prestar assistência judiciária gratuita aos necessitados (economicamente desprovidos ou hipossuficientes), no constitucionalismo brasileiro, germinou em 1934, quando o assunto ganhou tratamento de garantia fundamental. Não foi contemplada pela Constituição de 1937, retomando seu espaço nas Constituições posteriores e, especialmente, na Carta de 1988.

Conforme narra Pedro Lenza ${ }^{192}$, em estudo analítico-comparativo do assunto, a diferença fundamental entre a previsão contida na Constituição de 1988 e as anteriores é o seu alcance literal. Sob a égide das Constituições pretéritas ${ }^{193}$, a garantia se restringia à assistência judiciária gratuita. Ela foi regulamentada pela Lei 1.060/1950 que, sem dúvida, serviu de suporte para promover o acesso à justiça daqueles que não podem suportar os encargos financeiros do processo sem prejuízo do sustento próprio ou de sua família.

Mas a Constituição Cidadã ampliou a garantia da assistência judiciária, preferindo atribuir ao Estado o dever de prestar assistência jurídica, integral e gratuita aos cidadãos necessitados. Dessa forma, o direito de ser assistido por advogado perante o Judiciário foi estendido para o âmbito extrajudicial, englobando toda e qualquer necessidade de auxílio jurídico.

Essa preocupação com o acesso dos necessitados à assistência jurídica ampla está no âmbito da chamada primeira onda do acesso à justiça, fortalecida a partir da década de 1960, servindo para "superar os anacrônicos semicaritativos programas, típicos do laissez-faire", rememorando-se as lições de Cappelletti ${ }^{194}$. No caso do Brasil, o anacronismo se encontrava na restrita obrigação estatal de prestar assistência judiciária,

\footnotetext{
192 Direito Constitucional Esquematizado, 9a ed., São Paulo, Método, 2005, pp. 454/455 e Assistência jurídica, integral e gratuita e o fortalecimento da Defensoria Pública na Reforma do Judiciário, in Reforma do Judiciário analisada e comentada: Emenda Constitucional 45/2004 (coord. André Ramos Tavares, Pedro Lenza e Pietro de Jesús Lora Alarcón), Método, São Paulo, 2005, pp. 489/494).

${ }^{193}$ Importante estudo sobre a evolução do tratamento legislativo no que concerne à assistência jurídica é de Barbosa Moreira, $O$ direito à assistência jurídica: evolução no ordenamento brasileiro de nosso tempo, in Revista de Processo, n. 67, ano 17, julho a setembro de 1992, pp. 124/134, com destaque do autor à constatação de que, invertendo a lógica, o constitucionalismo brasileiro garantiu gratuidade judiciária antes assegurar assistência jurídica.

${ }^{194}$ Cf. Acesso à justiça cit., p. 33
} 
quando, em grande parte das vezes, o maior obstáculo ao acesso à justiça, é pré-processual e, por isso, demandaria auxílio mais abrangente ${ }^{195}$.

O papel da Defensoria Pública, a teor do art. 134 da Constituição Federal de 1988 é justamente esse: concretizar, em prol dos necessitados, o direito fundamental do acesso à justiça, com a superação de fatores econômicos e/ou psicológicos que obstruem aquele intento, para a equalização da posição do hipossuficiente frente a litigantes mais opulentos (ou, ao menos, diminuição dessa defasagem).

Por isso, a Defensoria Pública é qualificada pelo Constituinte como órgão essencial à função jurisdicional desempenhada pelo Estado, prestando serviço público e servindo de importante instrumento de realização do Estado Democrático de Direito ${ }^{196}$. Sua relevância reside também no fato de que o acesso à justiça pelos economicamente necessitados irradia efeitos sobre outros direitos fundamentais ${ }^{197}$, como igualdade material, moradia, saúde, educação, assistência social etc.

\footnotetext{
195 Ainda conforme observou Cappelletti, Acesso à justiça cit., p. 38, as barreiras que a assistência judiciária não conseguiu transpassar são, por exemplo: a impossibilidade de o cidadão pobre reconhecer uma "causa jurídica" a ponto de ser encorajado a procurar auxílio, ou identificar seus direitos e as áreas nas quais podem se valer de remédios jurídicos, de modo que os necessitados acabam se limitando a agir apenas diante de problemas mais corriqueiros ou prementes, em matéria criminal ou de família, ficando relegados problemas ambientais, consumeiristas, de inquilinato etc. Barbosa Moreira também anotou, em lições que se mantêm atuais, que "Ao que tudo indica, há entre nós, no concernente à vida jurídica, e particularmente nos estratos menos favorecidos da sociedade, uma forte demanda reprimida, uma enorme qualidade de prestações que não chegam a ser pedidas, de pleitos que não se formulam, de atos que não e praticam, e com freqüência nem sequer se tenta praticar - o registro de nascimentos pode, justamente, servir de exemplo. O fenômeno tem causas numerosas e variadas. Uma delas, bastante óbvia, é a falta de informação (...). Outras muitas dificuldades concorrem para bloquear aos desprovidos de meios o acesso ao jurídico: a distância a que vivem dos lugares em que se têm de praticar determinados atos, a escassez de tempo disponível para cuidar do assunto, inibições psicológicas e culturais de toda sorte... Nessa medida, o desatendimento das necessidades não resulta de deficiências na atuação dos agentes incumbidos de acudir àquelas, mas da abstenção dos próprios necessitados, que não os provocam" ( $O$ direito à assistência jurídica cit., p. 132). Aproveitando, ainda, o escólio de Carlos Alberto Salles, podemos afirmar que a atuação da Defensoria remove os custos de informação associados à litigância; no cenário mais ideal, com o auxílio da Defensoria Pública é superada a dificuldade do cidadão de percepção do problema jurídico (Políticas públicas cit., pp. 38/50).

${ }^{196}$ No entender de Leandro Coelho de Carvalho, a Defensoria Pública atua como elo entre os atores jurídicos (comunidade, entidades do terceiro setor e Poder Público). É agente de transformação social, já que sua atividade é, muitas vezes, a única porta de entrada - real e não retórica - para a cidadania dos indivíduos carentes. Ainda, o autor cita interessante estudo do Ministério da Justiça, em convênio com o Programa das Nações Unidas para o Desenvolvimento (Pnud), realizados sob a coordenação da professora de Ciências Políticas da Universidade de São Paulo, Maria Teresa Sadek, relacionando a estruturação das Defensorias, principalmente das unidades itinerantes, com melhoras no Índice de Desenvolvimento Humano (IDH) dos Estados (As atribuições da Defensoria Pública sob a ótica do acesso à ordem jurídica justa, in Revista de Processo, n. 156, ano 33, fevereiro 2008, pp. 204/224).

197 Conforme asseverou Roberto Gonçalves Freitas Filho na $1^{\mathrm{a}}$ Conferência de Defensoria Pública y Derechos Humanos, lembrado por Maria Cristina Vidotte Blanco Tarrega e Patrícia Mariano, “Al asegurar el acceso a la Justicia, la Defensoría realiza un Derecho Humano básico. Vencido este primer escalón, la Defensoria pone en examen del Estado-Juez, toda la gama de intereses del ciudadano carenciado" (Cf. A legitimidade da Defensoria Pública para propor ação civil pública, in Revista IOB de Direito Civil e Processual Civil, ano IX, n. 59, maio a junho de 2009, p. 101).
} 
Assim, a atuação da Defensoria Pública, como agente capaz de defender interesses dos necessitados, é o principal ator na potencialização do exercício da cidadania e na transformação social. Ao lado dos outros agentes públicos que detêm independência funcional, o defensor não se subordina a nenhum dos poderes estatais e só responde à "própria consciência"" 198 , conforme acentua Leandro Coelho de Carvalho.

Portanto, embora em patamar equivalente ao do Ministério Público na defesa dos direitos coletivos, o diferencial da Defensoria é a sua missão de salvaguardar os interesses dos "necessitados", justamente a classe social que por tanto tempo foi despojada de tutela jurisdicional. Nesse cenário, é relevantíssimo o papel social desempenhado pela Defensoria Pública na defesa individual dos interesses dos hipossuficientes.

Mas, no que se refere às causas de dimensão coletiva, a atuação da Defensoria Pública, mesmo sob a égide da Constituição Federal de 1988 foi já de início questionada, principalmente porque a Lei 7.347/85 não incluía em sua redação original a Defensoria dentre os entes legitimados à propositura de ação civil pública ${ }^{199}$.

O embate veio a ser solucionado em 2007, quando a Lei 11.448 sepultou qualquer dúvida a respeito da legitimidade da Defensora Pública para a defesa de interesses coletivos lato sensu ao incluí-la no rol do art. 82 do CDC. Felizmente, antes disso a jurisprudência já prevalecia no sentido da legitimidade da instituição para a defesa de interesses coletivos de relevância social e titularizados por cidadãos hipossuficientes ${ }^{200}$.

\footnotetext{
${ }^{198}$ Cf. As atribuições da Defensoria Pública cit., pp. 206/207.

${ }^{199}$ REsp 734176/RJ, Rel. Min. Francisco Falcão, $1^{\text {a }}$ Turma, j. 07/03/2006,.

200 REsp 555.111/RJ, Rel. Min. Castro Filho, $3^{\text {a }}$ Turma, j. 05/09/2006, em ação de tutela coletiva dos consumidores lesados por contratos de arrendamento mercantil atrelado à moeda estrangeira; REsp

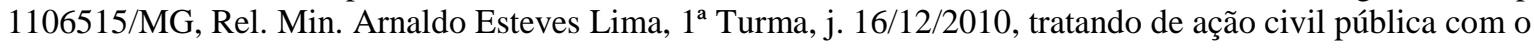
objetivo de assegurar o respeito à dignidade dos presos violada pela superlotação carcerária, em que se decidiu: "É imperioso reiterar, conforme precedentes do Superior Tribunal de Justiça, que a legitimatio ad causam da Defensoria Pública para intentar ação civil pública na defesa de interesses transindividuais de hipossuficientes é reconhecida antes mesmo do advento da Lei 11.448/07, dada a relevância social (e jurídica) do direito que se pretende tutelar e do próprio fim do ordenamento jurídico brasileiro: assegurar a dignidade da pessoa humana, entendida como núcleo central dos direitos fundamentais". Em outro precedente, esse mais recente, o STJ também se manifestou no sentido de que: "Na Ação Civil Pública, em caso de dúvida sobre a legitimação para agir de sujeito intermediário - Ministério Público, Defensoria Pública e associações, p. ex. -, sobretudo se estiver em jogo a dignidade da pessoa humana, o juiz deve optar por reconhecê-la e, assim, abrir as portas para a solução judicial de litígios que, a ser diferente, jamais veriam seu dia na Corte. (...) A categoria ético-política, e também jurídica, dos sujeitos vulneráveis inclui um subgrupo de sujeitos hipervulneráveis, entre os quais se destacam, por razões óbvias, as pessoas com deficiência física, sensorial ou mental” (REsp 931.513/RS, Rel. Min. Carlos Fernando Mathias, $1^{\mathrm{a}}$ Seção, j. 25/11/2009). No STF, a questão também foi assim decidida muito antes da Lei 11.448/08: "Estou em que o caráter altruístico da destinação institucional de tais entidades confere razoabilidade plena à outorga pelo Estado do patrocínio judicial gratuito das ações que sirvam à sua persecução, independentemente da indagação in concreto da sua capacidade financeira para arcar com os ônus da defesa privada" (ADI 558 MC, Relator Min. Sepúlveda Pertence, Pleno, j. 16/08/1991).
} 
No âmbito do Estado de São Paulo, a legitimação da Defensoria Pública, para a defesa dos necessitados, no âmbito coletivo, se firmara com fulcro no art. $5^{\mathrm{a}}$ da Lei Complementar n. 988/2006, in verbis: "São atribuições institucionais da Defensoria Pública do Estado, dentre outras: (...) III - representar em juízo os necessitados, na tutela de seus interesses individuais ou coletivos, no âmbito civil ou criminal, perante os órgãos jurisdicionais do Estado e em todas as instâncias, inclusive os Tribunais Superiores; (...) VI - promover: (...) c) a tutela individual e coletiva dos interesses e direitos da criança e do adolescente, do idoso, das pessoas com necessidades especiais e das minorias submetidas a tratamento discriminatório; d) a tutela individual e coletiva dos interesses e direitos do consumidor necessitado; e) a tutela do meio ambiente, no âmbito de suas finalidades institucionais; (...) g) ação civil pública para tutela de interesse difuso, coletivo ou individual homogêneo (...)".

Superado então o problema da ausência de previsão legislativa, uma dada interpretação da vocação constitucional da Defensoria Pública limita ainda mais a possibilidade de iniciativas dessa instituição em defesa de interesses coletivos por meio de ação civil pública.

Entendeu-se que à Defensoria Pública é vedado agir judicialmente em prol de interesses nitidamente detidos somente por aqueles que não se enquadram na qualidade de necessitados economicamente ${ }^{201}$.

Ao lado disso encontra-se a ideia construída, sob a ótica do devido processo social, e que vem se consolidando na doutrina ${ }^{202}$, de que merecem assistência jurídica não

\footnotetext{
${ }^{201}$ No exemplo de Fredie Didier Jr. e Hermes Zaneti Jr., "não poderia a Defensoria Pública promover ação coletiva para a tutela de direitos de um grupo de consumidores de Playstation III ou de Mercedez Bens" (op. cit., p. 218). Para uma análise da missão constitucional da Defensoria Pública, Leandro Coelho de Carvalho propõe interpretação cuidadosa, pois "uma abertura excessiva poderá desviar o Defensor Público de suas reais atribuições constitucionais - sob a falsa aparência de 'função atípica'. $O$ órgão de execução não pode descurar da população carente nem adentrar o campo de outras instituições (Ministério Público, p. ex.) ou ramos privados (como a advocacia)" (cf. As atribuições da Defensoria Pública cit., p. 217).

${ }^{202}$ Grinover, Acesso à justiça e o Código de Defesa do Consumidor, in O Processo em sua evolução cit., Rio de Janeiro, Forense Universitária, 1996, pp. 116/117, com considerações a respeito do acesso à ordem jurídica justa e da concretização da democracia participativa, e Código Brasileiro de Defesa do Consumidor comentado cit., $10^{\text {a }}$ ed., pp. 92/93, com oportuna lembrança à advertência de Carlos Alberto Salles, segundo quem, no que diz respeito aos interesses supraindividuais, estamos sempre diante do problema da $s u b$ representação (Políticas públicas e legitimidade para defesa de interesses difusos e coletivos cit., p. 50), que merece ser superado com maior ampliação possível do acesso à justiça. Anda em defesa da legitimidade da Defensoria Pública para a defesa dos interesses dos carentes jurídicos ou organizacionais, vejam-se: Mancuso, Contribuições esperadas do Ministério Público e da Defensoria Pública na prevenção da atomização judicial dos megaconflitos, in Revista de Processo, vol. 33, n. 164, outubro de 2008, p. 161 e Ação civil pública cit., p. 153/155; Mirra, Participação, processo civil e defesa do meio ambiente no direito brasileiro cit., vol. I, pp. 121/122; Leandro Coelho de Carvalho, As atribuição da Defensoria Pública, apud Álvaro Luiz Marrey Mirra, op. cit., p. 122. Em sentido contrário: Luiz Rodrigues Wambier, Teresa Arruda
} 
só os carentes econômicos, mas também os chamados carentes organizacionais ou jurídicos, categoria que sofre da dispersão de seus titulares, reclamando, portanto, o suporte da Defensoria Pública.

Segundo Didier e Zaneti, a atuação da Defensoria Pública nesse segmento compõe sua função atípica, pois "seu destinatário não é o necessitado econômico, mas sim o necessitado jurídico"203.

Para nós, contudo, há de se fazer distinção. Nada mais típica do que a atuação da Defensoria Pública em prol dos carentes organizacionais e também econômicos. Mas também é típica a iniciativa da Defensoria Pública se o interesse tutelado não pertencer exclusivamente a pessoas carentes, na medida em que se estendam a outros indivíduos não rigorosamente necessitados na concepção econômica. Assim, também nessa hipótese, não se nega a legitimação da Defensoria Pública ${ }^{204}$.

Aqui se faz presente o requisito chamado de pertinência temática, que exige coerência entre os objetivos institucionais do legitimado ativo e a tutela pretendida, ou seja, "um vínculo de afinidade entre o legitimado e o objeto litigioso" $" 205$. No caso da Defensoria Pública, é indispensável a congruência entre os seus fins institucionais, previstos expressamente pela Constituição Federal, e o benefício almejado com a demanda coletiva.

Dessa forma, admite-se apenas reflexamente que sejam beneficiados pela atuação da Defensoria Pública cidadãos não carentes. Isso porque é inconstitucional a sua inércia, em prejuízo dos efetivamente necessitados, a favor dos quais a sua atuação é imperativa, a pretexto de ser vedada a iniciativa da Defensoria Pública em ações coletivas em prol dos não necessitados.

\footnotetext{
Alvim Wambier e José Miguel Garcia Medina, Breves comentários à nova sistemática processual civil 3, São Paulo, Revista dos Tribunais, 2007, pp. 312/313.

${ }^{203}$ Cf. Curso de direito processo civil cit., pp. 216/217.

${ }^{204}$ Essa é a opinião de Leandro Coelho de Carvalho (As atribuições da Defensoria Pública cit., pp. 208 e 216/217), para quem o termo "necessitado" não equivale a "pobre". Vide também: Raphael Manhães Martins, A Defensoria Pública e o acesso à justiça, in Revista CEJ, n. 30, julho a setembro de 2005, pp. $27 / 28$, que defende uma ótica instrumentalista do papel da Defensoria, "isto é, que considera os escopos extrajurídicos do sistema normativo, se um pacato cidadão de classe média utiliza um serviço de telefonia celular, usa um serviço bancário ou, ainda, 'vai ao mercado da esquina comprar pão', caberá a esta instituição protegê-lo, em virtude da sua hipossuficiência como consumidor, independentemente do fato de que, a par disso, ele possa contratar advogados para defendê-lo".

${ }^{205}$ Cf. Fredie Didier Jr. e Hermes Zaneti Jr., op. cit., p. 212.
} 
Mas, quando os pretensos beneficiados da ação coletiva, no feliz exemplo de Fredie Didier Jr. e Hermes Zaneti Jr., são apenas os consumidores de PlayStation III ou de Mercedez Benz, falece legitimidade à Defensoria, pela ausência de pertinência temática.

Aqui, vale uma relevante nota, para não incorrermos em aparente contradição. Já sustentamos que a noção de "necessitado" que autoriza o agir da Defensoria Pública está dissociada da concepção puramente econômica do vocábulo; ou seja, enfatizamos que prevalece sim a ruptura, nesse cenário, com a simples aferição econômica da condição de carência.

Todavia, essa ideia não pode conduzir ao abandono dos já conhecidos fatores da carência organizacional, dentre os quais se encontram, como dito, os obstáculos de informação, psicológicos e econômicos. Para nós, portanto, é lícito dizer que, a ausência do fator econômico, dentre os diversos outros que podem levar à carência organizacional, faz sucumbir a legitimidade da Defensoria Pública ${ }^{206}$.

\section{Coisa diversa é o aproveitamento do processo movido pela Defensoria} Pública. Deve-se ter em mente que a demanda movida pela Defensoria não favorecerá apenas aqueles que ostentem a qualidade de cidadãos economicamente carentes, pois, consoante advertem com êxito Fredie Didier Jr. e Hermes Zaneti Jr., "não se pode confundir o critério para a aferição da capacidade para conduzir o processo coletivo com a eficácia subjetiva da coisa julgada coletiva" ${ }^{207}$.

Nesse aspecto, a opinião de Teori Albino Zavascki ${ }^{208}$ diverge. Para esse autor, não convém negar legitimidade à Defensoria para a defesa de interesses que

\footnotetext{
206 Opinião similar é compartilhada por Leandro Coelho de Carvalho, para quem: "Uma abertura excessiva poderá desviar o Defensor Público de suas reais atribuições constitucionais - sob a falsa aparência de 'função atípica', o órgão de execução não pode descurar da população carente nem adentrar o campo de outras instituições (Ministério Público, p. ex.) ou ramos privados (como a advocacia)" (As atribuições da Defensoria Pública cit., p. 217), e por Anginaldo Vieira, que propõe a aferição da condição de hipossuficiência por meio de "indicadores de miserabilidade": "1") situação: é notório que todos os beneficiários de uma ação civil pública são hipossuficientes (...) $2^{a}$ ) situação: é notório que todos os beneficiários de uma ação civil pública não são hipossuficientes [hipótese em que o autor nega a legitimidade de Defensoria]; e $3^{\text {a }}$ ) situação: é notório que grande parte dos beneficiários de uma ação civil pública são hipossuficientes" ( $O$ sentido da Constituição, disponível em <http://www.dpu.gov.br/pdf/artigos/ArtigoAnginado.pdf〉, acesso em 15/04/2011, pp. 4/5).

207 Op. cit., p. 218.

${ }^{208}$ Cf. voto-vista datado de 26/02/2008, proferido no julgamento do REsp no 912.849-RS, com referência ao teor do acórdão recorrido, da lavra de Araken de Assis, e lembrando o posicionamento também de Gregório Assagra de Almeida, no mesmo sentido: "Volvendo ao ponto, não vejo obstáculo algum, não me adiantando acerca de outros aspectos, no que tange à comprovação da necessidade dos consumidores 'lesados'. Conforme explica GREGÓRIO ASSAGRA DE ALMEIDA (ob. cit., pp. 500-501), basta a firmação da existência dos direitos individuais homogêneos, decorrendo do acolhimento do pedido uma condenação genérica, que será oportunamente liquidada, individualizando-se os beneficiários do comando do provimento
} 
inerentes também a cidadãos não necessitados, na fase do cumprimento do julgado, mas em caso de sentença favorável, só serão legitimados a se habilitarem aqueles que atenderem ao requisito da hipossuficiência econômica.

No entender de outro legitimado, no entanto, a Defensoria é proibida por norma constitucional de atuar de qualquer modo em favor dos não necessitados. Assim se posicionou a Associação Nacional dos Membros do Ministério Público que, diante da edição da Lei 11.448/2007, ajuizou ação direta de inconstitucionalidade (ADI n. 3943) perante o STF arguindo que a lei impugnada afeta as atribuições do Ministério Público, impedindo-o de exercer plenamente sua incumbência de autor de ações civis públicas, além de contrariar o art. 134 da Constituição Federal.

Contra esses argumentos, encontram-se em favor da atuação da Defensoria outros dois que, na opinião da posição doutrinária que aqui acompanhamos ${ }^{209}$, facilmente superam os supostos óbices vislumbrados pela CONAMP. São eles: a legitimidade atribuída ao Ministério Público, e aos demais legitimados para a ação coletiva, não é exclusiva e, ao contrário do sustentado naquela ADI, a atuação de outras entidades na defesa dos interesses coletivos só tende a aperfeiçoar o acesso à justiça dos necessitados (ainda que assim seja reflexamente conferida tutela jurisdicional também aos não necessitados).

Afinal, a pretexto de não socorrer os cidadãos mais abastados, não é lícito recusar a iniciativa da Defensoria em prol também dos hipossuficientes, quando a matéria em tela admitir tratamento uniforme. Não há espaço para monopólio ou reserva de mercado em matéria de legitimação concorrente para as ações coletivas ${ }^{210}$, principalmente em terreno no qual sempre imperou - e ainda impera - a sub-representação.

\subsubsection{Ministério Público}

Como fiscal da lei (art. 92 do CDC), é praticamente inquestionável ${ }^{211}$ a conveniência da intervenção do Ministério Público em ações nas quais se discutam

judicial. Em tal oportunidade, posterior à emissão do pronunciamento (e, portanto, impossível erigir condição a priori), demonstrar-se-á a condição de 'necessitado'. Por óbvio, não se há de se pretender que quaisquer consumidores, incluindo os de grande renda (e consumo), sejam beneficiados pela ação da Defensoria Pública".

${ }^{209}$ Vide nota 202.

${ }^{210}$ Cf. Raphael Manhães Martins, A Defensoria Pública cit., p. 113.

${ }^{211}$ Não se tem notícia de que essa intervenção tenha encontrado sólida resistência na doutrina especializada. Segundo Ada Pellegrini Grinover (Código Brasileiro de Defesa do Consumidor comentado cit., $10^{\mathrm{a}}$ ed., p. 142), "existe, assim mesmo, um interesse público à correta condução do processo de índole transindividual, 
interesses de grupo, seja porque sua presença inibe e reprime colusões ou manobras dos sujeitos processuais, zelando pela idônea condução da ação, ou porque essa forma de atuação, descompromissada com um interesse predeterminado, está em perfeita consonância com a finalidade da instituição de defender a ordem jurídica e o regime democrático ${ }^{212}$.

Já na condição de autor de ações coletivas, o Ministério Público também cumpre relevante papel político. Como órgão estatal independente do Judiciário, atua sem afrontar o princípio da inércia do Estado-juiz e ao mesmo tempo supre a deficiência e a passividade da sociedade civil, ao assumir a defesa de interesses plurissubjetivos ${ }^{213}$.

Nesses termos, é suficientemente justificada a iniciativa do Ministério Público para as ações civis públicas envolvendo direitos difusos ou coletivos. Aliás, na realidade brasileira, com a criação de planos e rotinas de trabalho especializados para o cuidado com os direitos coletivos, judicial e extrajudicialmente (dentre outras tarefas zelosamente cumpridas pelo Ministério Público brasileiro), o engajamento da instituição é festejado pela maioria qualificada da doutrina ${ }^{214}$.

Mas, em se tratando da legitimação do Parquet para a tutela de interesses individuais homogêneos, o debate se intensifica e percorre interessantes rumos.

A configuração e o papel institucionais do Ministério Público, na Constituição Federal de 1988, estão definidos nos art. 127 e 129. E a leitura de tais

que aconselha a técnica ora utilizada”. Para José Miguel Garcia Medina e Fábio Caldas de Araújo (Mandado de segurança individual e coletivo, comentários à Lei 12.016, de 7 de agosto de 2009), São Paulo, Revista dos Tribunais, 2009, pp. 152/153), "não resta dúvida que sua presença é fundamental para a preservação do interesse público". Veja-se ainda: Didier e Zaneti, Curso de Direito Processual Civil cit., p. 343. Tanto é aconselhável, que a atuação do Ministério Público como fiscal da lei é prevista no Código Modelo de Processos Coletivos para a Ibero-América (art. $3^{\circ}$, parágrafo $3^{\circ}$ ). Em sentido inverso, Nelson Nery Júnior e Rosa Maria de Andrade Nery preconizam a dispensa da intervenção de órgão do Ministério Público quando o último já figurar como autor da ação coletiva (Código de Processo Civil comentado e legislação extravagante, $8^{\text {a }}$ ed., São Paulo, Revista dos Tribunais, 2004, p. 1428). Antônio Cláudio da Costa Machado, destacando a importância da figura do custus legis, nega que dele se exija vinculação ao interesse de alguma das partes, atribuindo-lhe assim o caráter de legitimado especial (A intervenção do Ministério Público no Processo Civil brasileiro, São Paulo, Saraiva, 1989, pp. 277/284). Ainda: Bedaque, O Ministério Público no processo civil: algumas questões polêmicas, in Revista de Processo, vol. 16, n. 61, janeiro a março de 1991, pp. $38 / 39$.

${ }^{212}$ Nas palavras de Cândido Rangel Dinamarco, nesse cenário, atuando como custos legis, "seu único compromisso é com o interesse público, o qual é a mola e elemento legitimador da própria existência do Parquet" (cf. Instituições de Direito Processual Civil cit., vol. II, 5ª ed., p. 430).

${ }^{213}$ Cândido Rangel Dinamarco destaca esse como o fundamento político da legitimidade ativa do Ministério Público para a propositura de ações civis públicas, no Estado moderno solidário (Instituições cit., p. 434).

${ }^{214} \mathrm{O}$ assunto mereceu até a atenção de Cappelletti ( $O$ acesso dos consumidores à justiça, in Revista de Processo, vol. 16, n. 62, abril/junho 1991, p. 208), que não economizou elogios ao MP brasileiro. Vide ainda por todos: Luis Roberto Proença, Inquérito civil cit., pp. 141 e ss., em que o autor cuidou de formular propostas enfáticas para o aprimoramento da instituição. 
dispositivos é que remete o intérprete aos seguintes questionamentos: está o Ministério Público autorizado a atuar em defesa dos interesses individuais homogêneos? Se sim, em que medida?

De acordo com a previsão do inciso III do art. 129, atribui-se ao Ministério Público legitimidade para "promover o inquérito civil e a ação civil pública, para a proteção do patrimônio público e social, do meio ambiente e de outros interesses difusos e coletivos". A primeira indagação surge a partir da falta de menção específica do constituinte à tutela dos direitos individuais homogêneos. Já a segunda questão se desenrola em função do caput do art. 127 da Constituição Federal, segundo o qual, "O Ministério Público é instituição permanente, essencial à função jurisdicional do Estado, incumbindo-lhe a defesa da ordem jurídica, do regime democrático e dos interesses sociais e individuais indisponíveis" 215 .

Aquilatando o debate, o Código de Defesa do Consumidor não fez qualquer ressalva no art. 82 quando arrolou o Ministério Público dentre os legitimados para a defesa dos interesses descritos no art. 81 (incluídos toda a categoria de individuais homogêneos).

$\mathrm{Na}$ esteira da literalidade do texto constitucional nasce a opinião mais restritiva daqueles que nega a legitimidade do Parquet para a defesa de interesses individuais homogêneos, ao principal argumento de que não é lícito ao Ministério Público “manifestar ação em favor de pessoas determinadas" e "na proteção de direitos disponíveis e divisíveis" ${ }^{216}$.

A corrente doutrinária mais ampliativa, por sua vez, recomenda o seguinte raciocínio: desde que os direitos individuais, embora disponíveis, sejam homogêneos e

\footnotetext{
${ }^{215}$ Em obra lançada em 1989, Costa Machado atrelava a intervenção do MP apenas em processos em que se verificava o fenômeno da indisponibilidade (A intervenção do Ministério Público cit., pp. 64/66 e 277).

${ }^{216}$ Nas palavras de Ives Gandra da Silva Martins, "O conteúdo das expressões 'consumidor e 'contribuinte' não se equivale e se está o MP expressamente autorizado à promoção da defesa dos direitos do primeiro, o mesmo não ocorre com relação ao segundo na hipótese de lançamento de tributos pela Municipalidade que, por sua vez, não se identifica na categoria de entidade comercial ou prestadora de serviços" (Ministério público - Direitos individuais disponíveis e ação civil pública, in Revista Forense, vol. 330, ano 91, abril a junho de 1995, pp. 252/253). Em sentido semelhante: Athos Gusmão Carneiro afirmando que o mero pleito indenizatório em favor de pessoas determinadas (e ausente extraordinária dispersão dos lesados) não autoriza a iniciativa do Ministério Público pois "não implica repercussão alguma nos eventuais interesses coletivos" (cf. Direitos individuais homogêneos, limitações à sua tutela pelo Ministério Público, in Revista de Processo, ano 26, n. 103, julho a setembro de 2001, pp. 197/198).
} 
haja relevância social do bem jurídico tutelado, está presente o interesse social a ser buscado pelo Ministério Público ${ }^{217}$.

De fato, a nós convence o raciocínio de que a Constituição Federal apenas não fez menção expressa à categoria dos direitos individuais homogêneos porque, quando de sua edição, ainda não vigia o Código do Consumidor, diploma no qual referida categoria foi tratada como direito coletivo lato sensu.

Adicione-se ainda que a judicialização coletiva dos direitos subjetivos, mesmo disponíveis, já guarda dimensão social relevante para provocar a atuação do Parquet. Para Rodolfo de Camargo Mancuso, "a nota adicional da indisponibilidade (...) decorre de sua relevância social, já que, de outro modo, isto é, quando o interesse seja puramente individual, ainda que concernente a um cúmulo de indivíduos, o manejo poderá ser feito pelas figuras litisconsorciais" ${ }^{218}$. Sinal disso é a própria permissão outorgada ao Ministério Público de assumir a titularidade da ação em caso de desistência ou abandono do processo coletivo pelo autor originário ${ }^{219}$.

Outro argumento a favor da ideia é a autorização constitucional para que outras atribuições compatíveis com os seus fins institucionais fossem outorgadas ao Ministério Público (art. 129, IX). Foi nessa toada que o legislador ordinário delegou ao Parquet a missão de batalhar coletivamente pelos direitos dos consumidores ${ }^{220}$.

Assim, nesse contexto, a legitimidade ativa do Ministério Público nos parece que é questão menos tormentosa. Enquanto instituição independente e que

217 Assim é a lição de Kazuo Watanabe e Ada Pellegrini Grinover, Código Brasileiro de Defesa do Consumidor comentado cit., $10^{\mathrm{a}}$ ed., pp. 86/88 e 140/141; Mancuso, Ação civil pública cit., 12a ed., p. 129. E mais: Renato Franco de Almeida, O Parquet na defesa dos direitos individuais homogêneos, in Revista Forense, vol. 362, ano 98, julho a agosto de 2002, p. 147; Paulo Gustavo Guedes Fontes, Legitimidade do MP para a defesa dos interesses individuais homogêneos: importância em face do caráter individualista do controle judicial da Administração no Brasil, in Revista Brasileira de Direito Público, Belo Horizonte, ano 6, n. 20, janeiro a março de 2008, pp. 129/130; Hugo de Brito Machado, O Ministério Público e os direitos individuais homogêneos, in Repertório Jurisprudência IOB, n. 18/1998, pp. 324/323; Antonio Raphael Silva Salvador, Ministério Público: exame de sua legitimidade para impetrar segurança e para defesa de interesses individuais homogêneos, in Revista da Escola Paulista da Magistratura, maio a outubro de 1997, pp. 39/40; José Carlos Baptista Puoli, Responsabilidade Civil do Promotor de Justiça, São Paulo, Juarez de Oliveira, 2007, pp. 152/154; José Reinaldo Guimarães Carneiro, O Ministério Público e suas investigações independentes, São Paulo, Malheiros, 2007, p. 88; Geisa de Assis Rodrigues, Ação civil pública e termo de ajustamento de conduta: teoria e prática, $2^{\mathrm{a}}$ ed., Rio de Janeiro, Forense, 2006, pp. 76/77; José Maria Rosa Tesheiner e Mariângela Guerreiro Milhoranza, Direitos indisponíveis e legitimação do Ministério Público para as ações coletivas relativas a direitos individuais homogêneos de natureza previdenciária, in Revista de Processo, ano 34, n. 173, julho de 2009, p. 18.

${ }^{218}$ Cf. Ação civil pública cit., $12^{\mathrm{a}}$ ed., p. 139

219 Carlos Henrique Bezerra Leite, A legitimação do Ministério Público para promover a defesa dos interesses individuais homogêneos, in Repertório Jurisprudência IOB, n. 16/2001, p. 318.

${ }^{220}$ Afinal, tal como sugere Zavascki, o art. 127 da CF é autoaplicável (Processo coletivo cit., pp. 220/224). 
representa a sociedade civil, falando em nome do interesse público, o Parquet congrega situação legitimante para a ação coletiva.

Não obstante isso, partilhamos da preocupação de boa parte da recente doutrina em fixar os critérios para aferição da relevância social do interesse em jogo. Não afirmaremos que toda ação coletiva veicula interesse social relevante ${ }^{221}$.

A razão disso é que não podemos ignorar a exigência de compatibilidade entre os fins institucionais do órgão ministerial e o bem jurídico tutelado in concreto pela ação coletiva ${ }^{222}$. Assim é que, discordamos da opinião de Nelson Nery Junior, pois não é a simples existência in abstrato da ação coletiva que autoriza a iniciativa do Ministério Público; isso é fator de legitimidade, que difere do interesse.

Com efeito, é de total relevância a busca de parâmetros que, quando aplicados in concreto tendo em vista os objetivos da instituição (pertinência temática), expressem a existência ou não de interesse do Parquet na tutela de interesses individuais homogêneos ${ }^{223}$.

A tarefa de destacar esses parâmetros foi muito bem desempenhada pelo Conselho Superior do Ministério Público do Estado de São Paulo, ao editar a Súmula de entendimento n. $7^{224}$, que pode ser representada pela seguinte fórmula: o Ministério Público está autorizado a figurar como autor coletivo: (i) na defesa de direitos com assento constitucional, relacionados por exemplo a saúde, segurança, educação, consumidor; (ii) quando houver intensa dispersão dos lesados ou das vítimas; ou (iii) em prol do

${ }^{221}$ Para a opinião contrária: Nelson Nery Junior, O Ministério Público e as ações coletivas, in Ação Civil Pública (Lei 7.347/85 - reminiscências e reflexões após dez anos de aplicação - coord. Édis Milaré), São Paulo, Revista dos Tribunais, 1995, pp. 385, que aduz "a simples circunstância de a lei haver criado uma ação coletiva, o seu exercício já é de interesse social, independentemente do direito material nela discutido".

${ }^{222}$ Cf. José Marcelo Menezes Vigliar, Tutela jurisdicional coletiva cit., p. 149; Marco Antonio Zanellato, A defesa dos interesses individuais homogêneos dos consumidores pelo Ministério Público, disponível em <http://www.aasp.org.br/aasp/servicos/revista_advogado/revista89/marco_zanellato.asp>, acesso em 23/08/2011. ${ }^{223} \mathrm{Na}$ defesa da pertinência temática na hipótese de ação coletiva movida pelo MP, vide: Luciano de Camargo Penteado, Tutela coletiva de direitos individuais homogêneos, in Revista de Direito Privado, n. 19, ano 5, julho a setembro de 2001, p. 166. Relacionando pertinência com interesse de agir: Gidi, Legitimación para demandar en las acciones colectivas, in La tutela de los derechos difusos, colectivos e individuales homogéneos cit., p. 116; e Mazzilli, A defesa dos interesses difusos em juízo cit., 20ª ed., pp. 349/351.

224 “O Ministério Público está legitimado à defesa de interesses ou direitos individuais homogêneos que tenham expressão para a coletividade, tais como: a) os que digam respeito a direitos ou garantias constitucionais, bem como aqueles cujo bem jurídico a ser protegido seja relevante para a sociedade (v.g., dignidade da pessoa humana, saúde e segurança das pessoas, acesso das crianças e adolescentes à educação); b) nos casos de grande dispersão dos lesados (v.g., dano de massa); c) quando a sua defesa pelo Ministério Público convenha à coletividade, por assegurar a implementação efetiva e o pleno funcionamento da ordem jurídica, nas suas perspectivas econômica, social e tributária”. Um dos primeiros a observar a utilidade dessa súmula para o regulamento da matéria foi Rodolfo de Camargo Mancuso (Sobre a legitimação do Ministério Público em matéria de interesses individuais homogêneos, in Ação civil pública - Lei 7.347/85 Reminiscências e reflexões após dez anos de aplicação cit., p. 445). 
funcionamento de um sistema econômica social ou jurídico chancelado pela ordem republicana (previdenciário, tributário, financeiro, bancário, habitacional).

Outrossim, a influência desses critérios também são sentidas na jurisprudência ${ }^{225}$.

Por isso, conforme assevera com acuidade Luiz Cláudio Carvalho de Almeida, "a indisponibilidade do direito não se mostra apta a permitir divisar as hipóteses em que exsurge a legitimidade do Ministério Público para a tutela de interesses coletivos" ${ }^{226}$, citando precedente do ex-Ministro do STF, Sepúlveda Pertence que propõe a identificação do "interesse social conforme a Constituição" a partir "da identificação do seu assentamento nos pilares da ordem social projetada pela Constituição e na sua correspondência à persecução dos objetivos fundamentais da República"227.

Assim nos convencemos de que não é admissível a distinção operada pela jurisprudência consolidada do STF entre as causas que, de um lado, envolvem direitos dos consumidores tuteláveis pelo MP, e de outro, dos contribuintes, por sua vez não tuteláveis pelo Parquet (RE 195.056, rel. Min. Carlos Velloso, j. 09/12/1999). Como já dito, a indisponibilidade, nesse cenário, não é o critério correto para determinar a presença de interesse de agir na causa pelo Ministério Público.

Até compreendemos a advertência lançada pelo STF em referido precedente, no sentido de que não há relação de consumo entre físco e contribuinte. Acontece que, sob outra ótica, questões de alta dispersão (como a ilegalidade da exação ou o pedido de condenação genérica à restituição dos impostos pagos por todos os contribuintes) podem ser zeladas pelo Ministério Público no papel de defensor da ordem

\footnotetext{
${ }^{225}$ Assim ao se editar a Súmula 643 do STF: "O Ministério Público tem legitimidade para promover ação civil pública cujo fundamento seja a ilegalidade de reajuste de mensalidades escolares"; ou se decidindo que: "o Ministério Público não tem legitimidade ativa para propor ação civil pública na qual busca a suposta defesa de um pequeno grupo de pessoas - no caso, dos associados de um clube, numa óptica predominantemente individual. (...) para a proteção dos interesses individuais homogêneos, seria imprescindível a relevância social, o que não está configurada na espécie" (REsp 1109335/SE, Rel. Ministro Luis Felipe Salomão, $4^{a}$ Turma, j. 21/06/2011); “A Quinta Turma do Superior Tribunal de Justiça, após reflexão sobre o tema em debate, alterou seu entendimento para reconhecer que o Ministério Público possui legitimidade ativa ad causam para propor ação civil pública em defesa de direitos de natureza previdenciária" (AgRg no REsp 1243409/PR, Rel. Min. Adilson Vieira Macabu, $5^{\mathrm{a}}$ Turma, j. 17/05/2011), o que parece ser um sinal de que em breve deverá ser revisto o enunciado da Súmula 430 do STJ: "O Ministério Público não tem legitimidade para pleitear, em ação civil pública, a indenização decorrente do DPVAT em benefício do segurado"; "O Ministério público tem legitimação para ação civil pública em tutela de interesses individuais homogêneos dotados de alto relevo social, como os de mutuários em contratos de financiamento pelo Sistema Financeiro da Habitação" (RE 470135 AgR-ED, rel. Min. Cezar Peluso, 2a Turma, j. 22/05/2007).

${ }^{226}$ Cf. A Legitimidade do Ministério Público para a defesa dos direitos individuais homogêneos do consumidor, in Revista de Direito do Consumidor, n. 52, ano 13, outubro a dezembro de 2004, p. 82.

${ }^{227}$ RE 213631, rel. Min. Ilmar Galvão, Pleno, j. 09/12/1999.
} 
tributária (art. 50, II, “a”, da Lei Complementar n 75/93), que nitidamente constitui interesse público relevante ${ }^{228}$.

Vale dizer, não consentimos com a afirmação de que "no plano fiscal, o interesse social, a rigor, coincide com o de arrecadar o tributo e não com o de conjurá-lo" (voto do Min. Ilmar Galvão no RE nº 231.631/MG, Pleno, j. 09/12/1999), pois representa um escudo do fisco contra legítimas investidas do Ministério Público em matéria tributária e, assim, um retrocesso na caminhada pela resolução uniforme de litígios com origem comum.

Não se trata de utilizar, neste caso, a ação coletiva para combater lei em tese ou como sucedâneo de ação objetiva de controle de constitucionalidade, pois a (in)constitucionalidade do tributo na situação em exame não constitui objeto do processo, mas sim causa de pedir e, portanto, não terá eficácia erga omnes ${ }^{229}$.

Também merece ser enfocado o tema do litisconsórcio facultativo entre os órgãos do Ministério Público em suas várias esferas.

É sempre lembrada a mensagem de veto presidencial que mencionou o art. 113 na ocasião de vetar os arts. $82, \S 3^{\circ}$, e 92 , parágrafo único, todos do CDC. Nesse particular, a jurisprudência do STJ deu a interpretação mais acertada para a interpretação da extensão do veto: “A referência ao veto ao artigo 113, quando vetados os artigos 82, § $3^{\circ}$, e 92 , parágrafo único, do CDC, não teve o condão de afetar a vigência do $\S 6^{\circ}$, do artigo $5^{\circ}$, da Lei 7.374/85, com a redação dada pelo artigo 113, do CDC, pois inviável a existência de veto implícito" (REsp 222582/MG, Rel. Ministro Milton Luiz Pereira, $1^{\text {a }}$ Turma, j. 12/03/2002).

Assim, a despeito da intenção de reprimir o litisconsórcio entre os órgãos do Ministério Público em suas diversas escalas (manifestada na mensagem de veto ao art. 82,

${ }^{228}$ Em defesa da legitimidade do Ministério Público para propor ação coletiva em matéria tributária: Hugo de Brito Machado, O Ministério Público e os direitos individuais homogêneos cit., p. 323; Ana Lúcia Amaral e Luiza Cristina Fonseca Frischeisen, Legitimidade do Ministério Público para defesa dos interesses individuais homogêneos em matéria previdenciária e tributária, in Boletim dos Procuradores da República, ano 1, n. 4, agosto de 1998, p. 6; Antonio de Souza Prudente, Legitimação constitucional do Ministério Público para ação civil pública em matéria tributária na defesa de direitos individuais homogêneos, in Revista CEJ, n. 9, dezembro de 1999, p. 79; Luiz Cláudio Carvalho de Almeida, A legitimidade do Ministério Público cit. pp. 86/87.

${ }^{229}$ Em sentido semelhante: REsp 930.016/DF, Rel. Min. Eliana Calmon, $2^{\text {a }}$ Turma, j. 02/06/2009; AgRg no REsp 678.911/MG, Rel. Min. Luiz Fux, $1^{\text {a }}$ Turma, j. 09/08/2005. Em contrário, sob premissas equivocadas: “É entendimento assente no STJ a ilegitimidade do Ministério Público para propor ação civil pública visando impedir a cobrança de tributos, em vista de que contribuinte não se confunde com consumidor, cuja defesa está autorizada em lei, além de que funcionaria a referida ação como autêntica ação direta de inconstitucionalidade" (AgRg no REsp 937.117/RS, Rel. Min. Humberto Martins, 2a Turma, j. 21/02/2008). 
$\left.\S 3^{\circ}\right)$, permaneceu intacto o art. 113 , que serviria - e serviu - para alterar a redação do art. $5^{\circ}$ da Lei 7.347/85 e para torná-la harmônica com a nova regra.

Com essa leitura apegada aos princípios da unidade e da indivisibilidade do Ministério Público, irrepreensível a autorização para formação litisconsórcio entre o MP federal e estadual ou distrital (REsp 382.659/RS, Rel. Humberto Gomes de Barros, $1^{\text {a }}$ Turma, j. 02/12/2003, DJ 19/12/2003, p. 322). É fato que em se tratando de instituição una e indivisível, a conjugação de esforços de mais de um órgão do Ministério Público sequer equivale a um litisconsórcio, mas, no cenário em que o $\mathrm{CDC}$ foi concebido - de quebras de paradigmas processuais tradicionais - era louvável a autorização expressa para esse tipo de cooperação $o^{230}$.

\subsubsection{Associações}

Ocupando papel de destaque dentre os sujeitos legitimados para a defesa em juízo dos interesses individuais, o setor privado é representado pelas associações civis "legalmente constituídas há pelo menos um ano e que incluam entre seus fins institucionais a defesa dos interesses e direitos protegidos por este Código, dispensada a autorizada assemblear", na dicção do inciso III do art. 82 do CDC.

Embora ainda tímida no Brasil, a participação da sociedade civil na judicialização dos conflitos de massa é poderoso mecanismo de fortalecimento dos direitos e garantias individuais, na medida em que preenche com eficiência os vazios deixados pela leniência, voluntária ou não, dos órgãos estatais altamente burocratizados ${ }^{231}$.

Em outras palavras, em dois aspectos as associações civis têm vantagens sobre ações governamentais: sua atuação é precisa e imediata.

Primeiro, é precisa porque a união de indivíduos procura atender a um objetivo definido por seus membros, surgido nas diversas situações da vida, e que passa a constar dos seus atos constitutivos como finalidade institucional. Por cláusula constitucional (art. $\left.5^{\circ}, \mathrm{XVII}\right)$, a liberdade de associar-se é plena, desde que seus fins sejam lícitos. Assim, o associativismo consegue operar nos solos dos mais variados (e até

\footnotetext{
${ }^{230}$ Cf. Watanabe e Nery, Código de Defesa do Consumidor comentado cit., $10^{\mathrm{a}}$ ed., pp. 106 e 242/243.

${ }^{231}$ Assim, nas sábias palavras de Kazuo Watanabe, "somente pela união poderão as pessoas, com comunhão de interesses e necessidade, superar a debilidade individual" (cf. Tutela jurisdicional dos interesses difusos cit., p. 96).
} 
inusitados), sendo lícito afirmar que, no seu nascedouro, a associação é alheia de amarras temáticas.

E a importância disso é que o agir das associações é direcionado apenas pela vontade dos setores organizados da sociedade civil. Diferentemente dos entes públicos, o associativismo não encontra limites na perseguição do bem comum e geral.

O bem comum do associativismo é marcado por objetivos egoísticos e setoriais, mas também organizados nas mãos de um "ente coletivo", que deve ser portador das armas necessárias para a concretização de seus fins. Essa coesão entre a associação e os membros da comunidade é tão sólida que, conforme Kazuo Watanabe já ensinara em 1982, “A pessoa jurídica é, em suma, uma transparência, uma visibilidade, um veículo apenas, e seu objetivo estatutário é o dos próprios membros. Cuida-se de uma técnica jurídica para facilitar a defesa dos direitos e interesses, inclusive perante o Judiciário" ${ }^{232}$.

A segunda vantagem da agremiação civil é ser contemporânea aos interesses da sociedade. Esse imediatismo das associações, quando comparado com a máquina burocrática estatal, ganha muito em eficiência ${ }^{233}$ e credibilidade, pois elas são capazes de dar respostas tempestivas aos anseios de seus associados, tornando-se seus verdadeiros espelhos $^{234}$.

Um dos sinais dessa atuação imediata são os chamados ad hoc gruppen ${ }^{235}$ que, conforme dispõe o $\$ 1^{\circ}$ do art. 82 do Código, dispensam pré-constituição "quando haja manifesto interesse social evidenciado pela dimensão ou característica do dano, ou pela relevância do bem jurídico a ser protegido".

Assim, a sociedade civil tem tudo nas mãos para superar em eficiência os órgãos estatais quando o assunto é direitos transindividuais. Resta desenvolver, como

${ }^{232}$ Cf. Tutela jurisdicional dos interesses difusos: a legitimação para agir cit., p. 95. Cappelletti também indica que o zelo dos particulares organizados em grupo é marcante na experiência estrangeira de ações de classe (Formações sociais e interesses coletivos diante da justiça civil cit., p.145).

233 Cappelletti, Acesso à justiça cit., p. 57: "É pacífico, atualmente, que os grupos representativos podem demandar direitos coletivos que o Ministério Público não tenha vindicado eficientemente".

${ }_{234}^{234}$ Mirra, Participação, processo civil e defesa do meio ambiente no direito brasileiro cit., vol. I, p. 126.

235 "grupos formados depois da violação ao direito do grupo (ex post factum)", tradução livre de Antonio Gidi, Legitimación para demandar en las acciones colectivas cit., p. 115. Exemplos de associações ad hoc na experiência pretoriana brasileira: Associação dos Moradores do Jardim Cristal e Jardim Marambaia que defendeu os interesses individuais de moradores da região afetada por resíduos tóxicos da reciclagem de "borra de tinta" (REsp 706.449/PR, Rel. Min. Fernando Gonçalves, $4^{\text {a }}$ Turma, j. 26/05/2008); Associação de Defesa da Cidadania e do Consumidor no Estado de Pernambuco, em ação objetivando compelir empresas responsáveis pelo Conjunto Habitacional Jardim Petrópolis III a providenciar a mudança dos moradores do empreendimento (REsp 520.454/PE, Rel. Min. Barros Monteiro, 4 ${ }^{\text {a }}$ Turma, j. 15/04/2004; Associação Paranaense de Defesa do Consumidor para reclamar por diferenças de rendimentos de cadernetas de poupança (REsp 121.067/PR, Rel. Ministro Barros Monteiro, 4ª Turma, j. 17/04/2001). 
propõe a doutrina, uma nova mentalidade desapegada da postura passiva à espera do Estado paternalista.

Aliás, vale a nota de que discordamos dos autores que traduzem como injustificada, frente à tendência mundial do associativismo, a passividade da sociedade civil brasileira e o recurso frequente ao amparo do Ministério Público ${ }^{236}$.

Isso porque a garantia da livre associação é anterior a 1988, mas essa liberdade não veio sempre acompanhada dos instrumentos eficazes para a defesa dos direitos dos associados ${ }^{237}$. O grande divisor de águas no assunto, que é a Constituição de 1988, veio inaugurar uma nova fase do associativismo brasileiro ${ }^{238}$ e o Código de Defesa do Consumidor deu o retoque final ao tirar as associações dos bastidores para trazê-las à posição de protagonistas no cenário judicial que envolve os direitos transindividuais. A novidade não se resumiu a mera reforma processual, pois é um salto para uma mudança de mentalidade, que não ocorre em um piscar de olhos.

Além disso, alguns fatores econômicos ainda atuam como desestimulo para as associações se encorajarem em ações judiciais. Certo que o Código do Consumidor, no art. 83, tratou de atenuar o inconveniente econômico, ao eliminar a exigência de adiantamento de custas, mas também é fato que as despesas de manutenção de um processo judicial, principalmente com honorários de advogado, obram em desfavor de um engajamento mais acentuado de boa parte das associações. É essa dinâmica que ainda explica o fenômeno, sempre lembrado por Carlos Alberto de Salles, chamado de free riding (ou efeito carona), verificado quando há "um incentivo para os agentes se recusarem a contribuir, levando outras pessoas a suportarem os custos da participação política da iniciativa judicial ou mesmo da simples negociação",239.

Por tudo isso ainda estamos em tempo de confiar na organização da sociedade civil brasileira e no desenvolvimento do solidarismo, com a gradual escalada das

\footnotetext{
${ }^{236}$ Vide: Gidi, Coisa julgada e litispendência cit., p. 36; Barbosa Moreira, La iniciativa en la defensa judicial cit., p. 57; Lenza, Teoria geral cit., $2^{\mathrm{a}}$ ed., p. 196.

${ }^{237}$ Em lições lançadas antes de 1988, Hely Lopes Meirelles elucidava que, para a impetração do mandado de segurança (que tinha apenas conotação individual à época): "basta a personalidade judiciária, isto é, a possibilidade de ser parte para defesa de direitos próprios. O essencial para a impetração é que o impetrante pessoa física ou jurídica, órgão público, ou universalidade legal - tenha prerrogativa ou direito próprio e individual a defender, e que esse direito se apresente líquido e certo ante o ato impugnado" (cf. Mandado de segurança, ação popular e ação civil pública, São Paulo, Revista dos Tribunais, 1987, pp. 4/5).

${ }^{238}$ "Em termos de modelos processuais coletivos, o mandado de segurança coletivo distingue-se como a maior inovação da Constituição de 1988" (cf. Eurico Ferraresi, Ação popular, ação civil pública e mandado de segurança coletivo cit., p. 239).

${ }^{239}$ Cf. Políticas públicas e a legitimidade cit., p. 49.
} 
associações em direção à merecida posição de principal e mais atuante legitimado em ações coletivas $^{240}$.

Feita essa primeira análise sobre a justificativa social da legitimação das associações civis, passemos aos seus meandros jurídicos.

A propósito, o tema não se liga apenas às associações civis stricto sensu, pois a defesa de direitos individuais homogêneos pode se dar também por sindicatos de classe (em mandado de segurança coletivo) ou até, em linha mais ampliativa, por sociedades cooperativas $^{241}$.

Segundo se pronunciou o STF, é vedada a ação de partidos políticos para a defesa de interesses individuais homogêneos ${ }^{242}$, entendimento este que se situa na contramão da tendência legislativa contemporânea ${ }^{243}$.

\footnotetext{
${ }^{240}$ Afinal, conforme bem observa Elton Venturi, "as associações civis são as entidades naturalmente vocacionadas à promoção da tutela coletiva na medida em que nascem em decorrência do surgimento de interesses transindividuais ou individuais homogêneos provenientes de determinados grupos sociais" (cf. Comentários ao Código Modelo de Processos Coletivos cit., pp. 74/75).

241 "A cooperativa preenche o requisito oriundo do direito anglo-saxônico da representatividade adequada para promover ação em prol dos seus cooperados posto atingir as suas finalidades institucionais. Deveras, toda e qualquer condição que impeça o exercício do acesso à justiça deve ser interpretado restritivamente, por isso que o recurso não é ação e cooperativa não é associação para fins de exigir-se a anuência dos cooperados com o escopo de interpor recurso de terceiro prejudicado, em face de decisão notoriamente atentadora dos direitos daqueles. Manifestação recursal na qual a cooperativa visa a demonstrar que os taxistas autônomos não têm condições sócio-econômicas de concorrer contra empresas que, agindo em empreitada empresarial, concedem descontos que desequilibram o mercado, atentando, afrontando a ordem econômica que motivou a

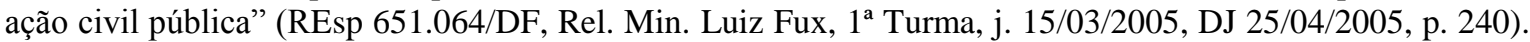
Também admitindo a legitimidade de cooperativas e qualquer outra forma de associativismo, v.: Watanabe, Código Brasileiro de Defesa do Consumidor comentado cit., $10^{\mathrm{a}}$ ed., p. 95.

${ }^{242} \mathrm{~A}$ argumentação, com todo respeito, não nos convence, pois, conquanto se reconheça a legitimidade ativa neutra ou universal dos partidos políticos, o critério para afastá-la no caso em julgamento foi material (tributos): "Se o Partido Político pode atuar na defesa do interesse de várias pessoas, independente de filiação, não pode, contudo, substituir todos os cidadãos na defesa de interesses individuais a serem postulados em juízo por meio de ações próprias. Por esses motivos, entendo que o Partido Político pode impetrar mandado de segurança coletivo na defesa de qualquer interesse difuso, abrangendo, inclusive, pessoas não filiadas a ele, não estando, porém, autorizado a se valer desta via para impugnar uma exigência tributária" (RE 196184, Min. Ellen Gracie, $1^{\mathrm{a}}$ Turma, j. 27/10/2004). Também, inconstitucionalmente restritiva é a regra do art. 21 da Lei 12.016/2009, que impõe aos partidos políticos o requisito da pertinência temática, quando o texto constitucional não a prevê. No mesmo sentido: Didier e Zaneti, Curso de direito processual civil cit., p. 222.

${ }^{243}$ Vide art. $3^{\circ}$, VIII, do Código Modelo de Processos Coletivos para Ibero-América. Na doutrina, defendendo a legitimidade dos partidos políticos para a defesa de direitos individuais homogêneos: Leonel, Manual do Processo Coletivo cit., p. 150; Vigliar, Questões atuais sobre o mandado de segurança coletivo, in Revista do Advogado, n. 64, ano XXI, junho de 2001, pp. 84 e seguintes; Ivan Lira de Carvalho, $O$ mandado de segurança coletivo e os partidos políticos, disponível em <http://www.plenum.com.br/plenum_jp/lpext.dl//Dou/douciv/110d/1227/125f?fn=document-frame.htm\&f=templates\&2.0>, acesso em 30/06/2011; Luiz Manoel Gomes Júnior e Rogério Favreto, Comentários à nova lei do mandado de segurança, São Paulo, Revista dos Tribunais, 2009, pp. 176/178; e Ferraresi, Ação popular, ação civil pública e mandado de segurança coletivo cit., p. 248.
} 
Sob a égide da Constituição de 1988, foi a disciplina do mandado de segurança coletivo que guiou os trabalhos da jurisprudência no que diz respeito à legitimação de associações e sindicatos. A redação do inciso LXX do art. $5^{\circ}$ pecou por mencionar que por meio do mandado de segurança coletivo as entidades sindicais, de classe ou as associações defenderiam "interesses de seus membros ou associados", o que, a grosso modo, equivale à figura representação e não à substituição processual.

De início, não foi simples convencer que, na qualidade de legitimado extraordinário, a associação ou o sindicato não dependem de autorização específica de seus filiados para demandar em nome de todos os membros do grupo. Com o auxílio da doutrina já habituada com o tema na vigência do $\mathrm{CDC}^{244}$, aquela resistência inicial foi superada com a edição da Súmula $629^{245}$ do STF, que veio para reafirmar a qualidade de legitimado extraordinário da associação ou de sindicato que defende interesse de toda a classe ou grupo, sob pena de resumir o mandado de segurança coletivo a uma dimensão característica do mandado de segurança individual plúrimo ${ }^{246}$.

Também aperfeiçoando a disciplina do mandado de segurança coletivo, o art. $21^{247}$ da Lei 12.016/09 dispõe expressamente sobre a dispensa de autorização dos legitimados ordinários para a ação coletiva.

Não obstante todo esse esforço, por ato governamental consubstanciado nas Medidas Provisórias no 1.798-1/1999 e 2.180-35/2001, forças políticas inseriram na Lei 9.494/97 o parágrafo único do art. $2^{\circ}$-A, instituindo a exigência de que, em ações coletivas movidas contra o Poder Público, a inicial deverá ser instruída da assembleia que autorizou o ajuizamento da medida judicial bem como da relação nominal dos membros e respectivos endereços.

\footnotetext{
${ }^{244}$ Especificamente com a redação final do inciso IV do art. 82, in verbis: "dispensada a autorização assemblear".

245 "A impetração de mandado de segurança coletivo por entidade de classe em favor dos associados independe de autorização destes".

${ }^{246}$ Zavascki, Comentários à Nova Lei do Mandado de Segurança (coord. Napoleão Nunes Maia Filho, Caio Cesar Vieira Rocha e Tiago Asfor Rocha Lima), São Paulo, Revista dos Tribunais, 2010, p. 279. Assim, na atual jurisprudência, prevalece a dispensa de autorização dos filiados: AgRg no Ag 1153498/GO, Rel. Min. Napoleão Nunes Maia Filho, $5^{\text {a }}$ Turma, j. 29/04/2010, DJe 24/05/2010; REsp 184.986/SP, Rel. Min. Luis Felipe Salomão, $4^{\mathrm{a}}$ Turma, j. 17/11/2009.

247 "O mandado de segurança coletivo pode ser impetrado por partido político com representação no Congresso Nacional, na defesa de seus interesses legítimos relativos a seus integrantes ou à finalidade partidária, ou por organização sindical, entidade de classe ou associação legalmente constituída e em funcionamento há, pelo menos, 1 (um) ano, em defesa de direitos líquidos e certos da totalidade, ou de parte, dos seus membros ou associados, na forma dos seus estatutos e desde que pertinentes às suas finalidades, dispensada, para tanto, autorização especial".
} 
Nesse contexto, não podemos discordar da maioria da doutrina ${ }^{248}$ que reputa tal norma inconstitucional e que a deixa reservada para aplicação limitadamente aos casos em que o ente coletivo figura como representante processual e não como substituto. Além de obstacularizar o acesso à justiça, a norma institui, mais do que uma prerrogativa, um privilégio injustificável ${ }^{249}$ para a Fazenda Pública que ocupa a posição de ré em ação coletiva.

Ao lado do maleável requisito da pré-constituição por 1 (um) ano, a lei ainda preceitua que, para ser legitimada à propositura de ação coletiva, a entidade associativa deve incluir em seus fins institucionais a defesa do direito a ser tratado em juízo. Assim também se exige da associação civil possuir pertinência temática com o assunto sub judice, ou seja, afinidade material entre os escopos institucionais e objeto da lide coletiva.

A pertinência temática é pressuposto que se liga naturalmente às associações civis, pois elas são geradas espontaneamente no seio da sociedade e, para sua própria existência como pessoa jurídica dotada de personalidade, devem perseguir um objetivo pré-definido. Traduz a preocupação de se exigir do autor da ação coletiva que, na ocasião de sua constituição, ele tenha prestado compromisso pela defesa dos interesses transindividuais. Assim, já se sabe que o seu ativismo e patrimônio podem ser dedicados ao tema e que foi essa a razão pela qual seus filiados uniram esforços.

Muito se discute acerca da natureza do requisito da pertinência temática e a doutrina se divide entre os que afirmam se tratar de aspecto da legitimidade de parte $\mathrm{e}^{250}$

\footnotetext{
${ }^{248}$ Grinover, A Ação Civil Pública no STJ, in A Marcha do Processo, Rio de Janeiro, Forense Universitária, 2000, p. 39; Watanabe, Código Brasileiro de Defesa do Consumidor comentado cit., 10ª ed., p. 96; Lenza, Teoria geral cit., $2^{\text {a }}$ ed., p. 200; Leonel, Manual do Processo Coletivo cit., p. 162; Luiz Paulo da Silva Araújo Filho, Ações coletivas cit., pp. 170/171; Sérgio Shimura, Tutela coletiva e sua efetividade, São Paulo, Método, 2006, pp. 100/101; Cassio Scarpinella Bueno, O poder público em juízo, $4^{\mathrm{a}}$ ed., São Paulo, Saraiva, 2008, p. 133; Nelson Nery Junior e Rosa Maria de Andrade Nery, Código de Processo Civil comentado e legislação extravagante, $11^{\mathrm{a}}$ ed., São Paulo, Saraiva, 2010, pp. 1475/1476; Nelson Nascimento Diz, Apontamentos sobre a legitimação das entidades associativas para a propositura de ações coletivas em defesa de direitos individuais homogêneos de consumidores, in Aspectos polêmicos da ação civil pública (coord. Arnoldo Wald), São Paulo, Saraiva, 2003, p. 324; Hugo Nigro Mazzilli, A defesa dos interesses difusos em juízo cit., $20^{\mathrm{a}}$ ed., p. 527.

249 "somente seria cogitável uma exigência geral e indiscriminada, e não uma exigência exclusivamente para as ações propostas em face de entes públicos, como foi instituído pela MP $\mathrm{n}^{\circ} 1.906$, porquanto não se verifica aí nenhuma desequiparação legítima, 'fundada e logicamente subordinada a um elemento discriminatório objetivamente aferível, que prestigie, com proporcionalidade, valores abrigados no Texto Constitucional', valendo-nos, mais uma vez, da precisa conceituação de Luís Roberto Barroso" (cf. Luiz Paulo da Silva Araújo Filho, Ações coletivas cit., p. 170).

${ }^{250}$ Assim: Mancuso, Ação civil pública cit., 12ª ed., p. 167; Luiz Manoel Gomes Júnior e Rogerio Favreto, Comentários à Nova Lei do Mandado de Segurança cit., p. 183; Arruda Alvim, Código do Consumidor Comentado cit., p. 389; Didier e Zaneti, Curso de Direito Processual Civil cit., p. 212; Aluísio Iunes Monti
} 
aqueles que defendem a ligação com o interesse de agir ${ }^{251}$. Posição intermediária é defendida por Ricardo de Barros Leonel, para quem a pertinência temática "está centrada na aferição da legitimação e/ou interesse de agir a partir da hipótese concretamente considerada" ${ }^{252}$.

Em nossa opinião, na análise do liame entre a medida judicial preconizada pelo ente coletivo e o seu escopo institucional, está ínsita a ideia de adequação e, por isso, pertinência temática mais se liga ao interesse do que à legitimidade.

Aqui, a acepção leiga da palavra interesse contribui para reforçar a tese: no momento da criação de uma entidade associativa, os seus membros moldam os objetivos institucionais a partir de seu interesse em dado setor da vida civil e, assim, a associação é voltada para determinado fim.

O ato constitutivo da associação serve, portanto, em juízo como indicador de interesse, verificado in concreto a partir do compromisso assumido pela associação com a defesa de certos direitos. Dito de outra forma, em tempos de incentivo ao associativismo, apenas o interesse encontra-se no campo da livre iniciativa (e pode ser espontaneamente direcionado pela sociedade civil) e não a legitimidade ${ }^{253}$.

\subsubsection{Poder Público}

No estudo dos entes legitimados para a tutela coletiva dos consumidores, optamos por dar ênfase em capítulos próprios à Defensoria, ao Ministério Público e às associações da sociedade civil. São as figuras que mais assimilaram a incumbência de

Ruggeri Ré, A Defensoria Pública como instrumento de acesso à Justiça coletiva: legitimidade ativa $e$ pertinência temática, in Revista dos Tribunais, v. 167, p. 237; Mirra, Participação cit., vol. I, p. 281. A jurisprudência dos tribunais superiores segue essa linha: REsp 1177453/RS, Rel. Min. Mauro Campbell Marques, 2a Turma, j. 24/08/2010; EDcl no REsp 949.494/RJ, Rel. Min. Luiz Fux, $1^{\text {a }}$ Turma, j. 27/04/2010, DJe 10/05/2010; ADI 3413, rel. Min. Marco Aurélio, Pleno, j. 01/06/2011.

251 Vide: Gidi, Legitimación para demandar en las acciones colectivas cit., p. 116; Zavascki, Processo coletivo cit., p. 199; Luiz Paulo da Silva Araújo Filho, Ações coletivas cit., pp. 96/97; Shimura, Tutela coletiva e sua efetividade cit., p. 69; Mazzilli, A defesa dos interesses difusos em juízo cit., pp. 292 e 296 , embora o autor adiante que a pertinência temática não se confunde com as condições da ação, transparece de suas considerações a aproximação com a noção de interesse, quando afirma: "Os demais legitimados, e até mesmo, a nosso ver, União, Estados, Municípios e Distrito Federal deverão ter interesse concreto na defesa do interesse objetivado na ação civil pública ou coletiva"; Cabiedes, Comentários ao Código Modelo de Processos Coletivos cit., p. 93.

${ }^{252}$ Cf. Manual do Processo Coletivo cit., p. 173.

${ }^{253}$ Esse entendimento fica coerente com a opinião antes defendida de que, na defesa de direitos coletivos, as associações são legitimados extraordinários, na medida em que os seus fins institucionais não atuam como indicadores de legitimidade, mas sim de interesse. 
defensores de direitos individuais homogêneos em juízo. Ainda assim vale a menção aos demais legitimados que figuram no rol do art. 82 do CDC.

A experiência até aqui mostrou que as entidades públicas especificamente destinadas à defesa dos interesses transindividuais, tais como os Procons e as Agências Reguladoras, empenham-se notadamente no plano extrajudicial. Nesse contexto, a doutrina ainda identifica "um vácuo que virá ocupado pelas pressões das classes ou categorias prejudicadas ou insatisfeitas, reclamos esses exteriorizados, na via judicial, pelas ações de tipo coletivo" ${ }^{254}$, denunciando o baixo desempenho das instâncias administrativas na tutela coletiva dos interesses individuais homogêneos, o que faz desaguar o conflito para a instância judicial cuja iniciativa, no mais das vezes, é exercida pelo habitual legitimado Ministério Público.

Ou seja, em tema de defesa coletiva dos interesses individuais homogêneos, as entidades públicas ainda falham na seara administrativa e pouco se encorajam no pólo ativo na esfera judicial. Essa deficiência ou omissão, no caso das agências reguladoras, as coloca frequentemente no polo passivo de ações coletivas ${ }^{255}$.

Neste ponto, vale anotar a existência de onda reformadora do CDC, capitaneada por um dos autores do anteprojeto, Herman Benjamin para quem: "A redução da litigiosidade se faz com o fortalecimento criativo dos mecanismos autorregulatórios dos próprios setores envolvidos - como conciliação e mediação - e ampliação da capacidade dos Procons de intervir nos litígios" ${ }^{, 256}$.

As pessoas jurídicas de direito público, União, Estados, Municípios e Distrito Federal, foram encarregadas constitucionalmente da defesa do consumidor, conforme previsão do art. $5^{\circ}$, inciso XXXII, e por isso essa condição foi reafirmada no Código de Defesa do Consumidor. Trata-se de uma das expressões do caráter paternalista do Estado.

\footnotetext{
${ }^{254}$ Cf. Rodolfo de Camargo Mancuso, Ação civil pública cit., $12^{\mathrm{a}}$ ed., p. 187.

255 Exemplo disso é obtido de recente ação civil pública movida pelo Ministério Público Federal pois "verificou-se que os serviços de atendimentos emergenciais 190 (Polícia Militar - emergência policial) e 193 (Corpo de Bombeiros Militar) da Polícia Militar em São Paulo não dispunham de equipamentos aptos a receber mensagens das pessoas surdas ou com deficiência auditiva, justamente diante da falta de regulamentação de tais serviços pela ANATEL. Por conseguinte, os deficientes (surdos/mudos) tinham o seu direito à comunicação e à segurança violados, uma vez que não lhes era possível comunicar-se diretamente com os citados serviços de atendimento emergenciais" (decisão liminar datada de 07/06/2010, autos $\mathrm{n}^{\circ}$ 0009849-58.2010.4.03.6100, em curso na $7^{a}$ Vara Federal da Seção Judiciária de São Paulo).

256 Disponível em <http://www.stj.gov.br/portal_stj/publicacao/engine.wsp?tmp.area=398\&tmp.texto=100069>, acesso em 03/12/2010.
} 
Não pode ser surpresa a ineficiência das pessoas jurídicas de direito público em assuntos que vão além das ações governamentais tradicionais, principalmente em uma realidade, como a brasileira, em que não raro o primário papel do Estado de garantia do bem comum é negligenciado.

Cappelletti já havia chegado à "triste constatação" de que, sujeitas a pressão política, as instituições governamentais são incapazes de assumir a defesa de interesses difusos, mas sem esquecer importante detalhe: as limitações enfrentadas pela ação governamental nessa seara são inerentes às vezes à própria máquina burocrática ${ }^{257}$. Por essas razões, as pessoas jurídicas de direito público não são os mártires dos interesses transindividuais em juízo.

Ao lado da desmotivação ${ }^{258}$, a atuação de tais entes ainda se submete a condicionantes. É necessária a pertinência temática entre o objeto do processo e os limites territoriais do ente estatal. Dessa forma, na (escassa) jurisprudência acerca do tema, é possível encontrar decisões reconhecendo a legitimidade de município para combater dano ambiental localizado em seu território ${ }^{259}$, caso em que a coisa julgada coletiva poderá beneficiar interesses dos individualmente lesados.

Na doutrina, a exigência desse nexo entre o objeto da causa e os limites territoriais do Município ou do Estado autor da ação coletiva é decifrada por Kazuo Watanabe $^{260}$ e Rodolfo de Camargo Mancuso ${ }^{261}$, com o correto alerta de que, na sobreposição de interesses, vige a legitimação concorrente entre dois ou mais interessados.

\subsection{Representatividade adequada}

Como esclareceu a exposição de motivos do projeto da lei da ação civil pública (Projeto n. 3.034/84), o conceito de representatividade adequada foi buscado nas class actions do direito norte-americano. Segundo a Rule 23, é dever do juiz o controle ex

\footnotetext{
${ }^{257}$ Acesso à justiça cit., pp. 51 e 55.

${ }^{258}$ Mancuso, Ação civil pública cit., $12^{\mathrm{a}}$ ed., p. 170.

${ }^{259}$ REsp 297.683/RJ, Rel. Min. Humberto Martins, $2^{\text {a }}$ Turma, j. 19/02/2008. Na doutrina, Mazzilli assevera que esse nexo, ou pertinência temática, diz respeito ao interesse do ente estatal na tutela dos seus residentes ou dos bens de seu território (A defesa dos interesses difusos em juízos cit., 20ª ed., pp. 351/352).

${ }^{260}$ Código Brasileiro de Defesa do Consumidor comentado cit., $10^{\mathrm{a}}$ ed., p. 94, e Leonel, Manual do Processo Coletivo cit., p. 160.

${ }^{261}$ O Município enquanto co-legitimado para a tutela dos interesses difusos, in Revista de Processo, vol. 12, n. 48, outubro a dezembro de 1987 , pp. 53/55, com o exemplo ilustrativo de ação versando sobre a poluição do Rio Tietê, que é intermunicipal, e na qual a legitimidade seria tanto dos Municípios que o margeiam quanto do Estado de São Paulo.
} 
officio da atuação do representante do grupo e de seu advogado, controle este que não se esgota sequer com o trânsito em julgado.

No direito brasileiro, o controle da representatividade adequada do legitimado coletivo não foi expressamente autorizado pela Lei 7.347/85 (a previsão que constava do projeto n. 3.034/84, ou Projeto Bierrenbach, não foi aprovada pelo legislativo) nem pela Lei 8.078/90, o que se traduziu no entendimento doutrinário ${ }^{262}$ de que esse controle ocorrera ope legis, presumindo o legislador que os legitimados elencados no art. 82 do Código de Defesa do Consumidor detinham representatividade para ser porta-voz dos membros do grupo ${ }^{263}$.

Preconizava-se que ao juiz não era lícito controlar ou restringir a representatividade daquele que vinha a juízo, atendendo aos pressupostos legais previstos no art. 82 do CDC. Fundamentos dessa conclusão eram a possibilidade de o Ministério Público, participante obrigatório como fiscal da lei em todas as ações coletivas (art. 92 do CDC), fazer-se substituir ao autor da demanda, assumindo a titularidade da ação coletiva, caso constate a sua desídia ou atuação contrária aos interesses do grupo, e formação de coisa julgada somente a favor dos membros do grupo.

Um dos primeiros nomes a sustentar que, mesmo sob a égide das Leis 7.347/85 e 8.078/90, a representatividade adequada do autor coletivo não poderia ser negligenciada na ação coletiva brasileira foi Antonio Gidi, que propôs interpretação de lege lata para reconhecer o dever do juiz de sanar os problemas de representatividade, afinal, representante inadequado, numa leitura constitucional, é um não representante ${ }^{264}$.

Diante disso, o autor retomou os caminhos já trilhados pela doutrina brasileira, principalmente por Ada Pellegrini Grinover, de que a cláusula da representatividade adequada tem fundamento na Constituição, na garantia do devido processo legal, a fim de assegurar aos membros do grupo "a melhor defesa judicial, a

262 Grinover, Código Brasileiro de Defesa do Consumidor comentado cit., $5^{\mathrm{a}}$ ed., 1998, pp. 802/806; Pedro da Silva Dinamarco, Ação civil pública cit., 2001, pp. 201/202; Nelson Nery Junior e Rosa Maria de Andrade Nery, Código de Processo Civil comentado, $3^{\mathrm{a}}$ ed., 1997, p. 1137; Arruda Alvim, Código do Consumidor Comentado cit., pp. 381/382.

${ }^{263}$ Ada Pellegrini Grinover afirmava que: "A doutrina de raiz romanística considera de difícil aplicabilidade aos sistemas da civil law as soluções do direito norte-americano, preconizando que os controles ali exercidos pelo juiz passem a ser rigorosamente estabelecidos pelo legislador" (A tutela jurisdicional dos interesses difusos no direito comparado, in A tutela dos interesses difusos, São Paulo, Max Limonad, 1984, p. 82).

${ }^{264}$ A representação adequada nas ações coletivas brasileiras: uma proposta, in Revista de Processo, vol. 108, n. 61, 2002, p. 66. Cassio Scarpinella Bueno já havia criticada a presunção de representatividade supostamente acolhida pelo legislador brasileiro (As class actions norte-americanas e as ações coletivas brasileiras: ponto para uma reflexão conjunta, in Revista de Processo, n. 82, abril a junho de 1996, pp. 92/151). 
ponto de afirmar-se que nesse caso o julgado não atuaria propriamente ultra partes , nem significaria real exceção ao princípio dos limites subjetivos da coisa julgada, mas configuraria, antes, um novo conceito de 'representação substancial e processual', adaptada às novas exigências emergentes na sociedade"265.

Concordamos com a ideia de que o controle da representatividade do autor coletivo não constitui óbice à justiça na medida em que, em se tratando de direitos transindividuais cujos titulares não são pessoalmente ouvidos em juízo, é mais legítimo um filtro que qualifica a representação e o acesso à justiça. Como acentua Carlos Alberto de Salles, "o sistema optou por privilegiar o critério da seletividade" ${ }^{266}$, um critério que não é numérico e que prima pela idoneidade e seriedade da propositura de ações coletivas, para garantir que uma pluralidade de sujeitos, ausentes em juízo, sejam defendidos de maneira adequada.

Não admitir o controle da representatividade significaria anuir com uma representação ilegítima e com um processo no qual o interesse em jogo não está sendo articulado da maneira mais próxima da perfeita. Por isso, representatividade adequada é fator de legitimidade ${ }^{267}$ e de efetividade do processo $^{268}$, que se alinha aos ditames do devido processo legal, na medida em que assegura a qualidade na judicialização dos interesses transindividuais, por iniciativa apenas de quem seja justa parte ${ }^{269}$.

Firmada a necessidade do controle, resta dizer no que consiste a requisito da representatividade adequada, tarefa que se recomenda seja também desempenhada pelo legislador brasileiro ${ }^{270}$.

\footnotetext{
265 Cf. As garantias constitucionais do processo nas ações coletivas, in Novas tendências do direito processual cit., pp. 57/58, e A tutela jurisdicional dos interesses difusos no direito comparado, in A tutela dos interesses difusos cit., p. 81.

${ }^{266}$ Cf. Políticas públicas e a legitimidade cit., p. 48.

${ }^{267}$ Lembrando as palavras de Luhmann, a legitimidade do procedimento é a "disposição generalizada para aceitar decisões de conteúdo ainda não definido, dentro de certos limites de tolerância" (Legitimação pelo procedimento, Brasília, UNB, 1980, p. 31). Então, da verdadeira representatividade do autor coletivo depende a disposição dos membros do grupo em acatar a decisão coletiva como o resultado da melhor condução possível do processo.

268 Suzana Henriques da Costa, $O$ controle judicial da representatividade adequada: uma análise dos sistemas norte-americano e brasileiro, in As Grandes Transformações do Processo Civil Brasileiro: homenagem ao Professor Kazuo Watanabe (org. Carlos Alberto de Salles), São Paulo, Quartier Latin, 2009, p. 975.

${ }^{269}$ Para lembrar a lição de Cappelletti, Formações sociais cit., p. 151. Álvaro Mirra ilustra que somente o representante adequado (ou sociológico, em suas palavras) é o "autêntico espelho" do grupo (Participação, processo civil cit. vol. I, p. 127).

270 'Esse 'superdimensionamento' do poder discricionário do juiz pode, porém, ser perfeitamente evitado pelo próprio legislador, a quem cabe excogitar e positivar os critérios que permitirão ao julgador aquilatar da 'representatividade adequada' do grupo no caso concreto. O que não se pode conceber é que o legislador se
} 
No direito norte-americano a adequacy of representation se situa dentre os prerequisites de uma class action. Ou seja, a presença da representatividade adequada determina, dentre outros quesitos, a existência de uma ação de grupo; sua ausência impede a certificação da class action. No item (a) da Rule 23, os números $(3)^{271}$ e $(4)^{272}$ regem a adequacy of representation e se traduzem na exigência de: comunhão de interesses entre o representante e os membros do grupo e atuação vigorosa do representante em prol dos interesses do grupo.

Foram nesses prerequisites da class action norte-americana que a doutrina brasileira foi buscar parâmetros para transportar o instituto para a ação coletiva brasileira.

Para Antonio Gidi, o controle sobre a representatividade adequada, a um só tempo, "minimiza o risco de colusão, incentiva a conduta vigorosa do representante e do advogado do grupo e assegura que se traga para o processo a visão e os reais interesses dos membros do grupo" ${ }^{273}$, palavras que bem destacam os elementos da representação adequada do autor coletivo.

Kazuo Watanabe também resumiu bem o conceito de adequado representante, ligado à "seriedade, credibilidade, capacidade técnica e até econômica do legitimado à ação coletiva",274. Essa é a linha seguida por boa parcela da doutrina mais recente $^{275}$.

Por sua vez, outra parte da doutrina brasileira minimizou os elementos da representatividade adequada. Para Hugo Nigro Mazzilli, eles se resumem à pertinência temática e à pré-constituição há mais de um ano ${ }^{276}$.

omita ou não exerça cabalmente sua função, deixando assim o juiz na situação de ter que fixar os critérios axiológicos que, a rigor, devem estar previstos em norma" (cf. Mancuso, Interesse difusos cit., $7^{\mathrm{a}}$ ed., p. 213). 271 "the claims or defenses of the representative parties are typical of the claims or defenses of the class".

272 "the representative parties will fairly and adequately protect the interests of the class".

273 cf. Gidi, A representação adequada cit., p. 61 e seguintes.

274 Os processos coletivos nos países de civil law e common law cit., p. 300.

${ }^{275}$ Grinover, Código Brasileiro de Defesa do Consumidor comentado cit., 10ªed., p. 178; Leonel, Manual do processo coletivo cit., pp. 162/163; Susana Henriques da Costa, O controle judicial da representatividade adequada cit., pp. 972/973; Swarai Cervone de Oliveira, Poderes do juiz nas ações coletivas, São Paulo, Atlas, 2009, p. 65; Ferraresi, Ação popular, ação civil pública e mandado de segurança coletivo cit., p. 118; Lionel Zaclis, Proteção coletiva dos investidores no mercado de capitais, São Paulo, Revista dos Tribunais, 2007, p. 110; Lenza, Teoria geral cit., $2^{\mathrm{a}}$ ed., p. 175; Maximilian Fierro Paschoal, A representatividade adequada e a discussão quanto à possibilidade do seu controle judicial no Brasil, in As grandes transformações do Processo Civil Brasileiro cit., pp. 910/914.

${ }^{276}$ A defesa dos interesses difusos em juízo cit., $20^{\mathrm{a}}$ ed., p. 290. Acompanham esse entendimento: Mancuso, Jurisdição coletiva e coisa julgada, $2^{\mathrm{a}}$ ed., São Paulo, Revista dos Tribunais, 2007, p. 433; Vigliar, Tutela jurisdicional coletiva cit., p. 146; Venturi, Processo Civil Coletivo cit., 2007, p. 222; Luiz Guilherme Marinoni e Sérgio Cruz Arenhart, Curso de Processo Civil-Procedimentos Especiais, vol. V, $2^{\mathrm{a}}$ ed., São Paulo, Revista dos Tribunais, 2010, p. 312; Didier e Zaneti, Curso de Direito Processual Civil cit., p. 215; 
Mas, na nossa opinião, a representatividade supera as noções de legitimidade ou de interesse (pertinência temática). Todo representante adequado é legitimado e possui interesse de agir na demanda mas ao sistema das ações coletivas isso não basta ${ }^{277}$.

Sob uma ótica estritamente processual, concordamos que o conceito de representatividade se aproxima da legitimidade dos países de civil law, pois, sem ela, o autor da ação de classe brasileira não estará autorizado a agir em nome dos membros do grupo $^{278}$. Mas não anuímos com a corrente doutrinária acima referida, pois o requisito da representatividade do autor coletivo não se contenta com a pertinência temática e a préconstituição.

É necessária uma análise do comportamento do representante sob um enfoque panprocessual, ou seja dentro e fora do processo, para além dos limites da relação jurídica processual ${ }^{279}$. Daí a importância de confiar ao juiz da ação coletiva o dever de examinar, para além da legitimidade, também a representatividade do demandante.

A longevidade do ente legitimado é um sinal de que ele pode ser adequado representante mas não é determinante, já que pode ser dispensada pelo juiz brasileiro (art. $82, \S 1^{\circ}$, do CDC).

Nelson Nery Jr. e Rosa Maria de Andrade Nery, Código de Processo Civil comentado e legislação extravagante cit., nota 10 ao art. $5^{\circ}$ da Lei n. 7.347/85.

277 Aliás, acerca da sobreposição entre alguns dos requisitos das class action, Antonio Gidi afirma: "Sobreposição, porém, não significa redundância, e os três requisitos não se confundem completamente porque cada um possui objetivos diversos e aborda aspectos diferentes do mesmo fenômeno. Os requisitos refletem aspectos diversos de uma única preocupação do legislador: assegurar que os interesses dos membros ausentes sejam adequadamente tutelados na ação coletiva, através de um processo coletivo adequado, em que o devido processo legal seja respeitado" (cf. A class action como instrumento cit., p. 137).

${ }^{278}$ Nesse sentido: Watanabe, Os processos coletivos nos países de civil law e common law cit., p. 300; Suzana Henriques da Costa, $O$ controle judicial da representatividade adequada cit., p. 959; Aluísio Iunes Monti Ruggeri Ré, A Defensoria Pública como cit., p. 236.

${ }^{279}$ Assim, para Flávia Hellmeister Clito Fornaciari, "uma pessoa é representante adequado de um grupo ou de uma classe independentemente da existência de um processo judicial, pois isso decorre da relação jurídica de direito material" (Cf. Representatividade adequada nos processos coletivos, tese de doutorado apresentada perante a Faculdade de Direito da Universidade de São Paulo, 2010, p. 50). Na mesma linha, Álvaro Mirra acentuou em estudo recente que a representatividade adequada "é uma especial qualidade que determinados titulares do direito de agir devem apresentar, consistente na capacidade de bem representar e defender em juízo os interesses da sociedade na proteção do meio ambiente, em perfeita sintonia com as expectativas da coletividade nessa matéria e com total autonomia e independência frente aos detentores do poder econômico (grandes grupos econômicos) e do poder políticos (os próprios governos)" (Participação, processo civil e defesa cit., vol. I, p. 194). No Código Modelo Processos Coletivos para a Ibero-América, a adequada representatividade do autor coletivo é destacada da legitimidade e está centrada em: "a - credibilidade, capacidade, prestígio e experiência do legitimado; b - seu histórico na proteção judicial e extrajudicial dos interesses ou direitos dos membros do grupo, categoria ou classe; c - sua conduta em outros processos coletivos; $\mathrm{d}$ - a coincidência entre os interesses dos membros do grupo, categoria ou classe e o objeto da demanda; $\mathrm{e}$ - o tempo de instituição da associação e a representatividade desta ou da pessoa física perante $o$ grupo, categoria ou classe". 
Por sua vez, a convergência de interesses entre o representante e os membros do grupo é essencial para assegurar a representação adequada na medida em que somente sob essa base a ação coletiva é conduzida da maneira mais vigorosa e alinhada com os componentes do grupo.

Embora um primeiro palpite pudesse ser no sentido de que esse tipo de controle é raro na realidade brasileira, há um exemplo de nítido controle de representatividade sob esse aspecto: constatado conflito de interesses entre os seus filiados, o STJ já negou legitimidade a uma associação de classe (RMS 19.803/MG, Rel. Min. Paulo Medina, Sexta Turma, j. 23/08/2005).

Para desvendar este ponto, recorremos a um exemplo: uma ação coletiva promovida por entidade representativa da classe dos servidores públicos na qual se postula a invalidação de um concurso público de promoção. Enquanto fala em nome de toda a categoria dos servidores públicos, interessada na lisura dos concursos internos, a associação detém legitimidade coletiva. Mas, sob a ótica dos interesses individuais dos servidores filiados e beneficiados pela promoção, pode-se entender que a entidade de classe não é representante adequada, pois está em juízo para defender interesse de parte de seus filiados, que é divergente do interesse de outra banda de filiados.

Antes de tudo, a questão para nós se resolve pela natureza do objeto litigioso e não pela negação de legitimidade prima facie, como se resolveu no âmbito do Superior Tribunal de Justiça. Na situação ilustrada, se ao beneficiar um integrante do grupo o resultado do processo necessariamente prejudica os interesses de outro, ocorre que o objeto da ação (defesa da lisura dos concursos internos de promoção) é incindível e, nessa ótica, transcende os interesses individuais dos membros do grupo ${ }^{280}$.

Então, a associação é parte legítima e eventuais ações dos legitimados ordinários seriam, no fundo, pseudoindividuais ${ }^{281}$. Negar a legitimidade da associação,

\footnotetext{
${ }^{280}$ Em outro contexto, mas em estudo muito recente, Daniela Monteiro Gabbay colacionou a lição do norteamericano Lon Fuller ao ilustrar os ali tratados conflitos policêntricos: "a distribuição dos jogadores de um time de futebol, pois qualquer mudança na posição de um deles afetará diferentemente os demais 10 jogadores em campo" (cf. Pedido e causa de pedir, São Paulo, Saraiva, 2010, p. 77), situação que para nós retrata um "conflito" que tem uma faceta coletiva ao lado de várias individuais.

${ }^{281}$ Em contexto semelhante, Antonio Gidi afirma: "Nem todo conflito existente entre o representante e o grupo compromete a adequação da representação. Alguns conflitos são irrelevantes do ponto de vista jurídico, outros meramente hipotéticos. Nem sempre é necessário que haja consenso entre todos os membros do grupo sobre a conveniência da propositura da ação, sobre a maneira como deve ser conduzida ou sobre o tipo de pedido feito. A mera existência, ou probabilidade, de que um conflito de interesses venha a surgir no curso de uma class action também não é suficiente para inviabilizar a tutela coletiva: o conflito precisa ser real e atual. Em Blackie v. Barrack decidiu-se que não é qualquer divergência de interesses entre os membros
} 
nesses casos, pode representar óbice para a judicialização do conflito, que por sua dimensão restrita à categoria, não motivará outro legitimado senão a entidade de classe.

Porém, no instante em que se analisa a situação sob a ótica individual dos filiados cujos interesses não estão sendo representados pela entidade de classe, de fato há um problema de representatividade. Contudo, ainda assim, insistimos que a solução não pode ser a extinção do processo em razão da ilegitimidade da associação de classe, mas sim considerar o nascimento de um subgrupo, em favor de quem deverá ser buscado um representante adequado ${ }^{282}$.

Como propõe Antonio Gidi ao examinar a class action norte-americana, a existência de interesses antagônicos dentro da mesma categoria pode conduzir à formação de subgrupos, "com a intervenção de outros membros como representantes ou da redefinição do grupo" ${ }^{\text {283. }}$.

No direito brasileiro, em que a formação de subgrupos não está expressamente autorizada em lei, de lege lata, deve ser admitida a intervenção de amicus curiae em condição semelhante àquele previsto no art. $482, \S 3^{\mathrm{o} 284}$, do Código de Processo Civil para a declaração incidental de inconstitucionalidade, a fim de representar os interesses do subgrupo ${ }^{285}$. Afinal, o princípio impulso oficial é mitigado no processo

do grupo que tem o condão de violar o devido processo legal. Os requisitos da adequada representação e da tipicidade da lide não exigem uma absoluta identidade de interesses. Em demonstração de extrema lucidez, a decisão ensina que é preciso comparar a seriedade e a extensão dos conflitos existentes com a importância das questões que unem o grupo a um objetivo comum" (Cf. Class action como instrumento cit., p. 117).

${ }^{282}$ A favor dessa ideia - com considerações não necessariamente atreladas ao regulamento das class action norte-americanas - Owen Fiss observa que: “A conexão instrumental entre o representante e a vítima também conduz a uma perspectiva que tolera, ou até incentiva, uma multiplicidade de representantes. (...) Em um processo judicial estrutural o padrão típico consiste em encontrar um grande número de representantes, cada um, talvez, representando diferentes ponderações acerca do interesse do grupo vitimado. (...) a multiplicidade de representantes não cria essas diferenças, elas existem no mundo real e a corte deve ouvir a todas antes de decidir o que é ideal para a questão apresentada" (cf. Um novo processo civil cit., pp. 53/54).

${ }^{283} \mathrm{Cf}$. Class action como instrumento cit., p. 120.

284 "O relator, considerando a relevância da matéria e a representatividade dos postulantes, poderá admitir, por despacho irrecorrível, a manifestação de outros órgãos ou entidades".

285 A figura do amicus curiae não seria assim desvirtuada. Conforme assevera Cassio Scarpinella Bueno, "Ele, o amicus curiae, tem que ser entendido como um adequado representante destes interesses que existem, queiramos ou não, na sociedade e no Estado ('fora do processo', portanto) mas que serão afetados, em alguma medida, pela decisão a ser tomada 'dentro do processo'. O amicus, neste sentido, atua em juízo em prol destes interesses e é por isto mesmo que, na minha opinião, sua admissão em juízo depende sempre e em qualquer caso da comprovação de que ele, amicus, apresenta-se no plano material (isto é: 'fora do processo') como um 'adequado representante destes interesses" (cf. Quatro perguntas e quatro respostas sobre o amicus curiae, in Revista Nacional da Magistratura, ano II, n. 5, Brasília, Escola Nacional da Magistratura/Associação dos Magistrados Brasileiros, maio de 2008, p. 133). E em texto mais recente e inédito, o mesmo autor acentua: “À falta de um procedimento próprio, que regule a forma de sua intervenção, não há por que afastar, para sua admissão, a disciplina que o Código de Processo Civil reserva para a assistência" (cf. Amicus curiae: uma homenagem a Athos Gusmão Carneiro, disponível em <http://www.scarpinellabueno.com.br>; acesso em 30/10/2011). 
coletivo e o juiz desempenha o papel de gestor do processo (defining function ${ }^{286}$ ), a quem se faculta a flexibilização da técnica e do procedimento a fim de operar a máxima tutela aos direitos coletivos.

Justamente nessa linha, o Projeto de novo Código de Processo Civil faculta, pelo art. 322, como modalidade de intervenção de terceiro, a manifestação do amicus curiae em processos dotados de relevância social nos quais é necessária a oitiva de pessoa natural ou jurídica com representatividade adequada a respeito da matéria debatida no processo.

Em contexto diverso, o legislador brasileiro cometeu o deslize de autorizar a atuação de representante não necessariamente adequado. $O$ art. $7^{\circ}$ da Lei n. 9.870/1999, dispõe que: "São legitimados à propositura das ações previstas na Lei no 8.078, de 1990, para a defesa dos direitos assegurados por esta Lei e pela legislação vigente, as associações de alunos, de pais de alunos e responsáveis, sendo indispensável, em qualquer caso, o apoio de, pelo menos, vinte por cento dos pais de alunos do estabelecimento de ensino ou dos alunos, no caso de ensino superior".

Isso significa que em ação que versar sobre mensalidades devidas às instituições de ensino, o mencionado apoio, de no mínimo $20 \%$ dos associados, equivale nada menos do que à convergência de interesses. Assim, descuidadamente, a Lei n. 9.870/1999 permitiu que, mesmo sob a oposição de 79\% dos alunos, pais ou responsáveis filiados, a associação possa representá-los em juízo na defesa de interesses coletivos lato sensu ${ }^{287}$.

Pensemos na hipótese em que determinada instituição de ensino estabelece desconto progressivo em mensalidades escolares, diretamente proporcional ao número de alunos-irmãos matriculados, mas a troco de uma pequeno aumento na mensalidade do aluno que não possui irmãos ali matriculados. É nítido o conflito de interesses entre os pais ou responsáveis por mais um aluno, de um lado, e os pais ou responsáveis por um único aluno, de outro, a justificar a eleição de representante para a defesa dos direitos do subgrupo que eventualmente não tenha autorizado, nos termos da lei acima mencionada, o ajuizamento da ação coletiva.

${ }^{286}$ V. Ada Pellegrini Grinover, Direito Processual Coletivo, in Direito Processual Coletivo e o anteprojeto cit., p. 13.

${ }^{287}$ Aliás, a disposição não é adequada mesmo que seja lida, não sob o aspecto da representatividade, mas da autorização assemblear, pois, como já estudado, esta também é impertinente em se tratando de legitimação extraordinária. 
Outra questão em torno do tema da representatividade nas ações coletivas, é saber se ela pode ser questionada em face de todos os legitimados, isto é, se o controle da representatividade adequada é problema exclusivo das associações civis ou ele também se apresenta frente aos órgãos públicos legitimados.

Entendemos que, pelas mesmas razões pelas quais a representatividade da associação civil não se esgota na pertinência temática e na pré-constituição - dados objetivos que não asseguram a defesa ideal dos interesses coletivos - os entes públicos legitimados não ostentam de per se a representatividade, ainda quando atendido o requisito da pertinência temática ${ }^{288}$.

Como já se afirmou, a representatividade supera as noções de legitimidade e interesse e, por isso, a fim de atender às garantias constitucionais do contraditório e da ampla defesa, não dispensa qualquer legitimado de demonstrar que: (i) conhece as necessidades do grupo; (ii) atua em consonância com as aflições dos membros do grupo; e (iii) trabalha energicamente na defesa dos interesses do grupo.

No Brasil e em geral nos ordenamentos fundados na civil law, em que a força da atividade legislativa, como fonte de direito, ainda é intensamente maior do que a dos precedentes judiciais, o que se propõe de lege lata, para encorajar na prática os juízes a exercerem preciso e explícito controle de representatividade, é que tais requisitos estejam claramente explicitados em lei. Lembrando uma das célebres lições de Barbosa Moreira, é desejável "que a lei - de preferência em termos flexíveis, reservada ao juiz margem razoável de liberdade no exame de cada espécie - estabeleça critérios de avaliação da idoneidade das associações para que possam reputar legitimadas" 289 .

\subsection{Ação coletiva passiva}

Não é difícil a conclusão de que parte legítima passiva em uma ação coletiva é a pessoa física ou jurídica, privada ou pública, que seja agente ou responsável pela lesão supraindividual afirmada em juízo.

\footnotetext{
${ }^{288}$ Como afirma Antonio Gidi, não é possível de se afiançar que o Ministério Público é representante adequado "Muito embora goze de uma presunção de competência, a verdade é que também o Ministério Público pode ser um representante inadequado em alguns casos específicos e caberá ao juiz da causa controlar sua atuação no caso concreto" (cf. Antonio Gidi, A representação adequada nas ações coletivas cit., p. 64). No mesmo sentido: Grinover, Ações coletivas Ibero-Americanas: novas questões sobre legitimação e a coisa julgada, in Revista Forense, v. 361, 2002, p. 5); Maximilian Fierro Paschoal, A representatividade adequada cit., p. 896.

${ }^{289}$ Cf. Tutela jurisdicional dos interesses coletivos ou difusos cit., p. 204.
} 
Questão diversa - e estritamente ligada ao tema da representatividade adequada - é a da admissibilidade no sistema brasileiro da ação coletiva passiva, isto é, da demanda promovida em face de determinada coletividade. O equivalente na common law norte-americana são as defendant class actions.

É inegável que o grupo ou a coletividade estão sujeitos a figurar no polo passivo de uma demanda coletiva a partir do instante em que figuram no polo ativo dela mesma. Isso porque as técnicas de ampliação do objeto do processo, como reconvenção, ação declaratória incidental e ações dúplices, conduzem o grupo ou a coletividade à posição de ré do processo coletivo (em ações coletivas passivas derivadas ${ }^{290}$ ) e não se encontram vedadas no microssistema de processos coletivos. Da mesma forma, não se ignora que o grupo ocupa o polo passivo de embargos de terceiro, embargos à execução, ou de ação rescisória, ações essas todas propostas pelo réu originário da ação coletiva.

Também há a autorização legal (art. $5^{\circ}, \S 2^{\circ 291}$, da Lei 7.347/85), para que o representante do grupo figure como litisconsorte de qualquer das partes em ação civil pública.

Mais delicada é a admissão do grupo na posição originária de réu de uma ação coletiva. Nos estudos pátrios, considerável vertente da doutrina nega a possibilidade de o legitimado coletivo figurar como réu em ação movida contra a coletividade, ao fundamento de que não há previsão legal para o substituto falar em nome dos substituídos na condição de demandados ${ }^{292}$.

$\mathrm{Na}$ experiência concreta, a jurisprudência se divide entre aderir à posição dessa corrente restritiva e seguir a tendência contemporânea de prestigiar a ação coletiva passiva. Para nós, o que determina esse empate é uma visão protecionista que se coloca do lado aparentemente vulnerável frente à parte contrária, critério que, como se verá, não é o correto para abonar ou não a legitimidade passiva do grupo.

\footnotetext{
${ }^{290}$ Watanabe, Código Brasileiro de Defesa do Consumidor comentado cit., $10^{\mathrm{a}}$ ed., p. 101.

291 "Fica facultado ao Poder Público e a outras associações legitimadas nos termos deste artigo habilitar-se como litisconsortes de qualquer das partes".

${ }^{292}$ Negando a legitimidade passiva do grupo no direito brasileiro: Gidi, Coisa julgada e litispendência cit., pp. 51/52; Mazzilli, A defesa dos interesses difusos em juízo cit., 20ª ed., p. 336; Arruda Alvim, Código do Consumidor cit., p. 354; Luiz Paulo da Silva Araújo Filho, Ações coletivas cit., p. 84; Pedro da Silva Dinamarco, Ação civil pública cit., pp. 269 e 272; Camilo Zufelato, Ação coletiva passiva no direito brasileiro: necessidade de regulamentação legal, in Em Defesa de um novo sistema de processos coletivos Estudos em Homenagem a Ada Pellegrini Grinover, São Paulo, Saraiva, 2010, p. 91, embora os dois últimos sugiram de lege ferenda que o sistema permita cautelosamente a presença do substituto processual do grupo no polo passivo da demanda.
} 
Assim, quando houve uma tentativa de formular pedido em face de toda uma categoria de trabalhadores ${ }^{293}$, prevaleceu no STJ o entendimento de que o sistema será infenso a um modelo de processo equivalente à defendant class action. De outro lado, há os ilustres casos no âmbito do Tribunal de Justiça de São Paulo de dissolução de torcidas organizadas de futebol ${ }^{294}$ em que a preocupação com a presença de uma coletividade indeterminável no polo passivo da demanda passou ao largo da discussão travada. Também deste lado se encontram as ações movidas contra federações que congregam instituições financeiras ou empresas de seguros e as ações possessórias movidas contra o MST visando a liberação de terras ocupadas por integrantes dos militantes ${ }^{295}$.

Em nossa opinião, o equívoco desse critério reside em franquear a ação coletiva passiva somente aos interessados nos casos de apelo social e midiático e, por outro lado, vedá-la quando se constata prima facie que o interesse em jogo cede frente à vulnerabilidade do grupo.

Diferente disso, duas considerações devem ser feitas. Primeira: ação coletiva passiva não redunda necessariamente em prejuízo ao grupo, tanto que, mesmo vulneráveis, os trabalhadores integrantes de uma dada categoria são representados passivamente por sindicatos em dissídios coletivos desde a vigência do Decreto-lei n. $1237 / 39^{296}$. Segunda: tanto na posição de ré como na de autora, o que garante a boa defesa dos interesses da coletividade é a garantia de que ela esteja adequadamente representada.

\footnotetext{
293 “A atribuição de legitimidade ativa não implica, automaticamente, legitimidade passiva dessas entidades para figurarem, como rés, em ações coletivas, salvo hipóteses excepcionais. Todos os projetos de Códigos de Processo Civil Coletivo regulam hipóteses de ações coletivas passivas, conferindo legitimidade a associações para representação da coletividade, como rés. Nas hipóteses de direitos individuais homogêneos, contudo, não há consenso. Pelo panorama legislativo atual, a disciplina da coisa julgada nas ações coletivas é incompatível com o pedido de declaração incidental formulado pelo réu, em face do sindicato-autor. A pretensão a que se declare a extensão dos efeitos de cláusula contratual, com eficácia de coisa julgada, implicaria, por via transversa, burlar a norma do art. 103, III, do CDC” (REsp 1051302/DF, Rel. Min. Nancy Andrighi, $3^{\text {a }}$ Turma, j. 23/03/2010).

${ }^{294}$ Em um dos arestos, ficou assentado: "Pretendeu-se acabar com a associação de pessoas que, aglutinadas para fazer do esporte um lazer e um exercício cívico, optaram pela rivalidade radical e que, se não for contida, descamba por uma intensidade bélica jamais prevista pelos sociólogos e militares" (AI n 0003591 44.1998.8.26.0000, rel. Enio Zuliani, j. 4/5/1999).

${ }^{295}$ Esses exemplos foram extraídos de Ada Pellegrini Grinover, Os processos coletivos nos países de civil law e common law cit., pp. 236/237; Mancuso, Ação civil pública cit., p. 193, Leonel, Manual do Processo Coletivo cit., p. 207; e Lenza, Teoria geral da ação civil pública cit., p. 211. Vide também: Diogo Campos Medina Maia, A ação coletiva passiva: o retrospecto histórico de uma necessidade presente, in Direito Processual Coletivo e o anteprojeto de Código Brasileiro de Processos Coletivos, São Paulo, Revista dos Tribunais, 2007, p. 338/340; e Zufelato, cit., pp. 102/107.

${ }^{296}$ Como lembra Camilo Zufelato, "se a decisão judicial impuser limitações a um direito transindividual, significa que esta é a exata medida do exercício desse direito. Nesse sentido, a ação proposta contra a coletividade não tem como escopo trazer danos aos direitos transindividuais, mas sim corrigir eventuais desvirtuamentos ou abusos no momento da efetivação desses" (cit., p. 92).
} 
Então, para além de uma simples legitimidade passiva, em se tratando de defendant class action, mais ilustrativa é a locução representatividade passiva.

Isso porque, se o grupo na posição de autor merece um adequado representante, com mais razão essa exigência se apresenta quando o grupo assume a condição de réu de uma ação coletiva, quando então não prescinde da melhor defesa possível de seus interesses. Sob outro ângulo, o controle da adequada representação do grupo passa a ser matéria do interesse da parte autora, que se empenhará na físcalização da aptidão do representante a fim de que a sentença prolatada vincule toda a coletividade.

Nessa linha são os ensinamentos de Ada Pellegrini Grinover, para quem o ordenamento brasileiro, de lege lata, "permite considerar a classe na posição de legitimada passiva - desde que observada escrupulosamente a aferição da representatividade adequada dos entes indicados como réus na demanda"297, anunciando tendência expressa no anteprojeto de Código Brasileiro de Processos Coletivos e no Código Modelo de Processos Coletivos para a Ibero-América.

Aliás, em lição pretérita, o Professor Flávio Luiz Yarshell destacou a lógica da representatividade passiva dos entes coletivos, propondo que "a improcedência da ação coletiva (exceto por insuficiência de elementos de prova) também atingisse os indivíduos, eis que quem tem 'adequada representação', deve tê-lo para o êxito e para o insucesso"298.

Paralelamente, ponto no qual há consenso é o de ser impossível ao Ministério Público e aos demais entes da Administração Pública figurarem no polo passivo de ação coletiva. No que diz respeito ao Parquet, a justificativa consiste na carência de personalidade jurídica do órgão ${ }^{299}$, o que, por si só, não nos convence já que o sistema convive tranquilamente com a outorga de capacidade processual a entes despersonalizados (ex vi do art. 12, incisos III, IV, V e IX, do CPC). Já relativamente aos demais entes públicos, faltam explicações na doutrina para a negativa de legitimidade coletiva passiva.

\footnotetext{
${ }^{297}$ Cf. Ações Coletivas Ibero-Americanas cit., p. 6. Secundando esse entendimento: Mancuso, Ação civil pública cit., p. 212; Didier e Zaneti, Curso de Direito Processual Civil cit., p. 425; Vigliar, Defendant class action brasileira, in Direito Processual coletivo e o anteprojeto cit., p. 317/319; Oliveira, Poderes do juiz nas ações coletivas cit., p. 66. Com atenuações, defendendo que a admissibilidade das ações coletivas passivas decorre de interpretação de lege lata: Leonel, Manual do Processo Coletivo cit., p. 208; Lenza, Teoria geral cit., pp. 212/213; Nancy Andrighi, Reflexões acerca da representatividade adequada nas ações coletivas passivas, disponível em: <http://bdjur.stj.jus.br/dspace/handle/2011/40618>, acesso em 23/11/2011, pp. $340 / 342$.

${ }^{298}$ Cf. Observações a propósito da liquidação na tutela de direitos individuais homogêneos, in Atualidades sobre liquidação de sentença (Teresa Arruda Alvim Wambier org.), São Paulo, Revista dos Tribunais, 1997, p. 160.

${ }^{299}$ Nesse sentido: Leonel, Manual do Processo Coletivo cit., p. 198; Mancuso, Ação civil pública cit., 12ª ed., p. 196; Gidi, Rumo a um Código cit., p. 367; Vigliar, Defendant class action brasileira cit., p. 314.
} 
Considerando o que já sustentamos neste trabalho, sobre o controle da representatividade adequada recair também sobre os legitimados governamentais para a ação coletiva, sonegar-lhes legitimidade passiva nos parece ser uma opção de pura política legislativa.

Mas o debate em torno do assunto não se esgota por aí. O grande dilema a respeito das defendant class action brasileiras se situa no particular caso do processo coletivo que tenha por objeto (direto ou reflexo) direitos individuais homogêneos.

Como decorre do art. 103, inciso III e $\S 1^{\circ}$, do CDC, a coisa julgada formada em sede coletiva não pode ser transportada para a esfera individual quando o pedido formulado pelo autor coletivo for julgado improcedente, em desfavor do grupo, portanto. Inverter a regra para aplicá-la em ação coletiva passiva significa vedar que os titulares individuais do direito sejam prejudicados pela procedência do pedido.

O senão é que ninguém vai a juízo contando com que a sua pretensão seja desacolhida. Isto é, o atual regime do transporte da coisa julgada coletiva in utilibus para a esfera individual, que não incentiva o opt in, desestimula o ajuizamento de ações coletivas passivas em se tratando exclusivamente de direitos individuais homogêneos, tornando o instrumento praticamente inócuo nesse contexto ${ }^{300}$.

Sob outro ângulo, em muitas situações, a efetividade do processo coletivo movido em face de um grupo depende da identificação de seus integrantes, tarefa impossível não raras vezes. Um exemplo: se um banco espera do Judiciário uma ordem para que todos os seus correntistas atualizem anualmente seus dados cadastrais, visando resguardar o direito de promover adequada cobrança em face de seus clientes, a efetividade da sentença de procedência depende da identificação e da comunicação de todos os membros do grupo, medida que se apresenta inviável diante do próprio cerne do litígio (clientes inadimplentes que não noticiam mudança de endereço). $\mathrm{Na}$ hipótese, portanto, não se preenche o requisito mencionado por Diogo Campos Medina Maia ${ }^{301}$, para a admissibilidade da ação coletiva passiva, da coletividade que, embora, definida, não é facilmente identificável.

\footnotetext{
${ }^{300} \mathrm{Na}$ mesma linha: Grinover, Ações coletivas ibero-americanas cit., p. 5; Zufelato, op. cit., pp. 133/135. Em direção oposta, argumenta Vigliar que, no manejo da ação coletiva passiva "não se pode imaginar a existência de interesses indivisíveis", propondo, de lege ferenda, que "a condenação terá eficácia para todos os integrantes da coletividade representada" (cf. Defendant class action brasileira, cit., p. 320).

${ }^{301}$ Op. cit., p. 340.
} 
Assim, tanto o tratamento processual quanto o contexto fático no qual se inserem os chamados direitos individuais homogêneos são fatores de desincentivo à propositura das ações coletivas passivas desse gênero, realidade essa que não pode ser ignorada pelo legislador em caso de tentativa de explicitar a autorização para a defendant class action brasileira.

Pensando dessa forma, o Anteprojeto de Código Brasileiro de Processos Coletivos idealizou a ação coletiva passiva versando restritivamente sobre direitos difusos e coletivos: "Art. 36. Ações contra o grupo, categoria ou classe - Qualquer espécie de ação pode ser proposta contra uma coletividade organizada, mesmo sem personalidade jurídica, desde que apresente representatividade adequada (art. 19, I, $a, b$, e $c$ ), se trate de tutela de interesses ou direitos difusos e coletivos (art. $3^{\circ}$ ) e a tutela se revista de interesse social.

Isso evidencia que, em matéria de direitos individuais homogêneos no Brasil, a ação coletiva passiva é um instrumento latente, que, para ser efetivo, aguarda uma revisita legislativa do regime da coisa julgada. 


\section{Competência}

\subsection{Competência para o processamento de ações coletivas versando direitos individuais homogêneos. Análise do alcance dos artigos $2^{\circ}$ da Lei 7.347/85 e 93 do Código de Defesa do Consumidor}

No contexto da competência para as ações coletivas em defesa dos interesses individuais homogêneos, o art. 93 do Código de Defesa do Consumidor disciplina que, ressalvada a competência da Justiça Federal, o foro competente para o processamento da demanda será: do foro do lugar onde ocorreu ou deva ocorrer o dano, quando de âmbito local (inciso I) ou do foro da Capital ou no do Distrito Federal, para os danos de âmbito nacional ou regional, aplicando-se as regras do Código de Processo Civil aos casos de competência concorrente (inciso II).

Aparentemente o microssistema processual coletivo empregou critério idêntico (territorial) ao do Código de Processo Civil na determinação da competência para as hipóteses de reparação de danos, outorgando competência ao foro do local do fato danoso (art. 100, V, “a”, do CPC). Mas, no regramento da ação civil pública (Lei n 7.347/85), o caput do art. $2^{\circ}$ já preceituava que o foro do local do dano terá competência funcional, enquanto o parágrafo único acrescenta regra de prevenção do juízo para causas intentadas com a mesma causa de pedir ou o mesmo objeto.

Assim, prevalece o entendimento ${ }^{302}$ de que se trata de competência absoluta, pois a lei a qualifica como funcional e não meramente territorial ${ }^{303}$, embora o parâmetro para se indicar o foro competente ao processamento da ação coletiva seja um aspecto geográfico que se aproxima da noção de competência territorial.

\footnotetext{
${ }^{302}$ Nesse sentido, vejam-se: Barbosa Moreira, A expressão "competência funcional” no art. $2^{a}$ da Lei da Ação Civil Pública, in Ação Civil Pública após 20 anos: efetividade e desafios (coord. Édis Milaré), São Paulo, Revista dos Tribunais, 2005, pp. 247/255; Leonel, Manual do Processo Coletivo cit., pp. 220/222, que justifica a opção do legislador por competência absoluta em razão do modo de ser do processo e das atividades que o juiz exerce, invocando lição de Moacyr Amaral dos Santos; Venturi, A competência jurisdicional na tutela coletiva, in Direito Processual Coletivo cit., p. 98, mencionando as palavras de Chiovenda no sentido de que a competência funcional é baseada, também, "na relação existente entre a lide e um fato ali ocorrido"; Mancuso, Ação Civil Pública, 12ª ed., p. 74; Grinover, Código Brasileiro de Defesa do Consumidor comentado cit., p. 146. Em direção contrária: afirmando se tratar de competência relativa, pela omissão do art. 93 do CDC: Mazzilli, A defesa dos interesses difusos em juízo cit., p. 267.

${ }^{303}$ Merece ser destacada a vigência de ambos os dispositivos (art. $2^{\circ}$ da Lei 7347/85 e 93 do CDC) para a disciplina da competência nas ações coletivas, uma vez que, consoante arts. 21 da Lei 7347/85 e 90 do CDC, deve prevalecer aplicação sistêmica e simultânea das regras previstas na Lei da Ação Civil Pública e no Código de Defesa do Consumidor, mediante um método integrativo (v. por todos: Grinover, Código Brasileiro de Defesa do Consumidor comentado cit. p. 143).
} 
De fato, há interesse público na máxima proximidade geográfica entre o foro competente para o trâmite da ação e o local do dano provocado ou iminente, proximidade que facilita a produção da prova necessária ao deslinde da controvérsia e privilegia o princípio da imediação, exaltando o contato do magistrado com os sujeitos envolvidos na lide ${ }^{304}$. Ainda, no caso de dano local, sobressai a facilitação do acesso à justiça em razão de o local do resultado do ato danoso coincidir com o foro do domicílio das vítimas ${ }^{305}$.

Então, na premissa de que, nas ações coletivas que visam à reparação de dano, a competência é absoluta, porque, funcional, não se cogita de modificação. Dessa forma, em ações coletivas em prol de titulares de interesses individuais homogêneos, também vale a regra geral de que a incompetência absoluta é matéria que pode ser conhecida de ofício e a qualquer tempo antes do trânsito em julgado (art. 267, §3º, inciso IV do Código de Processo Civil).

A relevância dessa distinção, como sabido, é que o foro que detenha competência relativa está sujeito à modificação da competência (seja por eleição de foro, prorrogação, derrogação, conexão ou continência), o que, a rigor, não ocorre com a competência absoluta. Da mesma forma, a prevenção, fenômeno que concentra a competência em um órgão jurisdicional, excluindo a competência de outros que, não fossem certas circunstâncias, seriam igualmente competentes, não teria lugar na hipótese aqui examinada ${ }^{306}$.

Contudo, firmado o caráter absoluto da competência prevista nos arts. $2^{\circ}$ da Lei 7.347/85 e 93 do CDC, por qual razão o legislador impõe a prevenção, para causa posterior, do juízo que primeiro conheceu de demanda anterior com mesma causa de pedir (conexão) ou objeto parcialmente coincidente (continência)? Pela mesma razão de conveniência que, conquanto empregue critério geográfico, qualifique a competência de funcional e, assim, absoluta. O interesse público presente na determinação da competência do órgão jurisdicional, que se localiza fisicamente tanto mais próximo do local do dano

\footnotetext{
${ }^{304}$ Mancuso, Ação civil pública cit., $12^{\mathrm{a}}$ ed., p. 90; Venturi, A competência jurisdicional na tutela coletiva cit., pp. 96/113, com destaque para pp. 96/97.

${ }^{305}$ Grinover, Código Brasileiro de Defesa do Consumidor comentado cit., p. 146. No entender de Vigliar, que aplaude o critério empregado no art. 93 do CDC, tais regras, orientadas por política legislativa, denotam a preocupação com a proliferação de diversas ações coletivas com base no mesmo ato causador de dano homogêneo (Interesses individuais homogêneos e seus aspectos polêmicos cit., pp. 70/71).

${ }^{306}$ Nessa linha, Cândido Rangel Dinamarco, enfatiza: "A regra de ouro da disciplina da prevenção é esta: jamais se considera prevento um juiz absolutamente incompetente para a causa" (cf. Instituições de Direito Processual Civil cit., vol. I, p. 468).
} 
quanto possível, também autoriza prevenir o juízo que primeiro tenha conhecido de demanda conexa ou que esteja julgando pedido mais abrangente, que contenha um pedido mais restrito formulado em outra demanda.

A esta altura, digna de nota é a ressalva contida no art. 93 do CDC. Com acerto, a redação do caput desse dispositivo já nos esclarece que a identificação do foro competente é precedida pela definição da "Justiça"307 competente: "Ressalvada a competência da Justiça Federal, é competente para a causa a justiça local (...)”.

Antes da edição do Código de Defesa do Consumidor, sob a égide apenas da Lei 7.347/85, problema surgia quando o local do dano não dispunha de vara federal instalada, o que levava doutrina e jurisprudência (sedimentada na Súmula 183 do STJ) a invocar a aplicação do art. 109, $\S 3^{\circ}$, da Constituição Federal, propugnando a competência do foro estadual.

Contudo, em julgamento de 10/01/2000, o STF $^{308}$ houve por bem afastar do regime das ações civis públicas, por ausência de previsão constitucional expressa, a regra contida no mencionado art. $109, \S 3^{\circ}$, precedente que conduziu o $\mathrm{STJ}^{309}$, em 8/11/2000, ao cancelamento da Súmula 183.

Prevaleceu, portanto, na jurisprudência, a competência da seção judiciária federal, nas causas elencadas nos incisos do art. 109 da Constituição.

Neste ponto, acompanhando a opinião de Ada Pellegrini Grinover ${ }^{310}$, Rodolfo de Camargo Mancuso ${ }^{311}$, Hugo Nigro Mazzilli ${ }^{312}$, Patrícia Miranda Pizzol ${ }^{313}$ e Arruda Alvim ${ }^{314}$, discordamos da posição assumida pelas cortes superiores. É verdade que a regra de competência funcional disposta em lei ordinária, embora absoluta, nunca pode derrogar norma constitucional que institui competência, também absoluta, em razão da pessoa. Porém, a própria Constituição autorizou que lei ordinária disciplinasse hipóteses

\footnotetext{
307 Aliás, é regra elementar do processo civil, que se traduz na didática lição de Athos Gusmão Carneiro: "Verificada a competência da Justiça brasileira, passamos a uma segunda etapa do juiz competente. Trata-se, já agora, de saber se o conhecimento da ação caberá à Justiça comum, ou a algum dos ramos das Justiças especializadas na área cível. (...) Todas as causas não previstas expressamente na Constituição Federal como de competência das Justiças Especializadas cabem à Justiça comum (...)" (cf. Jurisdição e competência, $2^{\mathrm{a}}$ ed., São Paulo, Saraiva, 1983, p. 53).

${ }^{308}$ RE 228955/RS.

${ }^{309}$ EmDecl CC 27.676/BA.

${ }^{310}$ Código Brasileiro de Defesa do Consumidor comentado cit., pp. 145/146.

${ }^{311}$ Ação civil pública cit., $12^{\mathrm{a}}$ ed., p. 80.

${ }^{312}$ A defesa dos interesses difusos em juízo cit., $20^{\mathrm{a}}$ ed., p. 272.

${ }^{313}$ A competência no processo civil, São Paulo, Revista dos Tribunais, 2003, pp. 574/577.

${ }^{314}$ Código do Consumidor Comentado cit., pp. 424/425.
} 
nas quais poderia ser autorizado o afastamento da competência da justiça federal $\left(\S 3^{\circ}\right.$ do art. 109), papel que foi desempenhado pelo art. 93 do CDC, de tal modo que ainda deve subsistir a competência da justiça estadual nas localidades em que não haja vara federal instalada.

Nesse contexto, vale lembrar dois aspectos relevantes que não determinam, por si só, a competência da Justiça Federal: a) o fato de o MPF ser autor da ação ${ }^{315}$; e b) a causa envolver interesse reflexo da União, de empresa pública federal, entidade autárquica federal ou fundação federal ${ }^{316}$.

Sendo então absoluta a competência territorial funcional disciplinada pelos arts. $2^{\circ}$ da Lei 7347/85 e 93 do CDC, e preservada a competência da Justiça Federal conforme mandamento constitucional (art. 109), passemos à identificação da extensão do dano, critério que define, como visto, se o foro competente será o do local do dano (dano local) ou da capital do Estado ou do Distrito Federal (dano regional ou nacional).

Essa distinção de foro competente a partir da extensão do dano é novidade do Código de Defesa do Consumidor. A regra até então vigente, do art. $2^{\circ}$ da Lei 7.347/85, não alcançava hipóteses tormentosas de danos cujos resultados superavam a fronteira de uma dada comarca, o que deixava o intérprete sob a égide das normas do Código de Processo Civil que, naturalmente, não provia solução adequada para o problema sob uma ótica molecular do conflito.

Mas a própria Lei 8.078/90, que inaugurou o tratamento da competência de acordo com a extensão do dano, não conceituou os chamados danos local, regional e

\footnotetext{
${ }^{315}$ Ricardo de Barros Leonel (op. cit., pp. 226/227), Hugo Nigro Mazzilli (A defesa dos interesses difusos em juízo cit., p. 276), e Nelson Nery Junior (Código Brasileiro de Defesa do Consumidor comentado cit., 10ª ed., p. 244) bem enfatizam que o Ministério Público Federal não integra a administração direta ou indireta da União. Mancuso acentua que a dedução em juízo, pelo Ministério Público Federal, de interesses transindividuais não equivale necessariamente à defesa dos interesses públicos, de titularidade da União (Ação civil pública cit., 12a ed., p. 77). Encorajados com a tese de que a presença do Ministério Público Federal não desloca por si só a competência da ação coletiva para a justiça federal, os idealizadores do Projeto de uma Nova Lei da Ação Civil Pública e do Código Modelo de Processos Coletivos para IberoAmérica previram nos respectivos diplomas autorização para formação de litisconsórcio entre todos os legitimados. Em sentido contrário, há julgados recentes de ambas as Seções do STJ: REsp 1057878/RS, Rel. Min. Herman Benjamim, $2^{\text {a }}$ Turma, j. 26/05/2009; CC 112.137/SP, Rel. Min. Paulo de Tarso Sanseverino, $2^{\text {a }}$ Seção, j. 24/11/2010; CC 86.632/PI, Rel. Min. Luiz Fux, 1ª Seção, j. 22/10/2008.

${ }^{316}$ A propósito disso, o STF já decidiu que: "Não é a Mata Atlântica, que integra o patrimônio nacional a que alude o artigo 225, $\S 4^{\circ}$, da Constituição Federal, bem da União. - Por outro lado, o interesse da União para que ocorra a competência da Justiça Federal prevista no artigo 109, IV, da Carta Magna tem de ser direto e específico, e não, como ocorre no caso, interesse genérico da coletividade, embora aí também incluído genericamente o interesse da União. - Conseqüentemente, a competência, no caso, é da Justiça Comum estadual” (RE 300244, rel. Min. Moreira Alves, $1^{\text {a }}$ Turma, j. 20/11/2001).
} 
nacional, relegando a tarefa para a doutrina e a experiência jurisprudencial, munidas dos elementos da realidade, como propõe Ricardo de Barros Leonel ${ }^{317}$.

Então, o sentido e o alcance das expressões dano local, dano regional e dano nacional são encontrados, caso a caso, por estimativa. Trata-se de critério criticado por Elton Venturi, porque incerto e desprovido de bases sólidas e conclusivas ${ }^{318}$, no entender desse autor.

Contudo, na medida em que, no mais das vezes, é disperso o resultado do ato danoso, produzido de forma homogênea a diversos sujeitos de direito, não vislumbramos modo mais seguro de identificação da extensão do dano que não seja a estimativa que, na realidade, é técnica empregada in statu assertionis ${ }^{319}$. Claro que estamos tratando, por ora, de fixar a competência do órgão julgador o mais próximo possível geograficamente da origem do dano, como já exposto. Por isso, entendemos que a estimativa da extensão do dano é critério científico suficiente e adequado.

Então, para se falar em dano local, basta que ele esteja circunscrito ao território de um município ou alguns municípios, dentro de um mesmo Estado, compreendidos em uma mesma Comarca. Ainda será local o dano cujo resultado reflita em várias Comarcas, que não integram propriamente uma região, de modo a não ser recomendada a competência do foro da $\mathrm{Capital}^{320}$. Em casos como tais, a competência deve ser concorrente entre os foros das diferentes comarcas ${ }^{321}$.

\footnotetext{
${ }^{317}$ Leonel, Manual do Processo Coletivo cit., p. 227.

${ }^{318}$ Venturi, A competência jurisdicional na tutela coletiva cit., p. 99.

${ }^{319}$ Mancuso, Jurisdição coletiva e coisa julgada cit., p. 505.

${ }^{320}$ Pedro da Silva Dinamarco sustenta que, caso a Comarca da Capital seja uma das atingidas pelo dano local, a sua competência prevalece sobre as demais: Competência, conexão e prevenção nas ações coletivas, in Ação Civil Pública após 20 anos: efetividade e desafios (coord. Édis Milaré), São Paulo, Revista dos Tribunais, 2005, pp. 505/518, especialmente p. 506.

${ }^{321}$ Certo que não há previsão legal específica para esta conclusão, mas, muito embora a circunscrição do dano supere o território de uma Comarca, não há dispersão suficiente para qualificá-lo como dano regional, não se justificando a competência do foro da Capital do Estado ou do Distrito Federal. Nesse aspecto, Leonel preconiza que "não é viável afirmar que o simples fato de se tratar de dano que alcance número considerável de cidades, faz com que o dano seja regional" e que o dano regional se aproxima da noção de dano estadual, devendo atingir a maior parte ou número elevadíssimo de cidades do Estado a fim de que seja firmada a competência da Capital (Manual do Processo Coletivo cit., p. 227). No TJSP, há precedente afirmando expressamente se tratar de dano local, aquele que, não tendo extensão suficiente para ser qualificado como regional, impõe a competência concorrente dos foros das Comarcas envolvidas (AI $\mathrm{n}^{\circ}$ 002737103.2004.8.26.0000, $9^{a}$ Câmara do extinto $1^{\circ}$ TAC, rel. Luis Carlos de Barros, j. 24/08/2004). Analisando essa hipótese, Ada Pellegrini Grinover invoca precedente da Câmara Especial do TJSP (JTJ 142/206) também firmando se tratar de competência concorrente (Código de Defesa do Consumidor comentado cit., $10^{\mathrm{a}}$ ed., p. 147). Em sentido contrário, Arruda Alvim se posiciona pela natureza regional do dano, desde que ele transcenda aos limites territoriais de uma dada Comarca (Código do Consumidor Comentado cit., p. 426).
} 
Quando, por sua vez, os resultados do dano superam os limites territoriais de um Estado, assumindo proporção maior que o dano local, mas sem atingir todo o território nacional, trata-se de dano regional, que impõe a competência concorrente do foro das Capitais dos Estados envolvidos e do foro do Distrito Federal.

Para além disso, quando o dano atingir os residentes em vários Estados da Federação (não necessariamente todos), de forma a produzir resultado que afeta todo o país, estaremos diante de dano nacional. Nessa hipótese, a literalidade do inciso II do art. 93 do CDC, aponta que há competência concorrente entre o foro da Capital dos Estados e do Distrito Federal.

Especificamente em se tratando de dano nacional, Arruda Alvim defende a competência exclusiva ao foro do Distrito Federal ${ }^{322}$. Também já haviam se pronunciado dessa forma Ada Pellegrini Grinover e Kazuo Watanabe, que optaram por eleger o foro do Distrito Federal como o de competência exclusiva para processar ação coletiva versando dano nacional, porque é a opção que mais assegura o due process of law, seja para facilitar o acesso à justiça ou a defesa do réu ${ }^{323}$, com base na presunção de que tanto os legitimados quanto os réus da ação coletiva podem saber, de antemão qual foro será o competente para processar demanda com objeto de tamanha magnitude.

No nosso entender, pela dicção do inciso II do art. 93 do CDC, convém manter a opção pela competência do juízo da Capital do Estado, também visando atender ao due process of law, considerando a possível hipótese de um dano que, embora nacional, em nada afete o território do Distrito Federal. Nesse sentido são as lições de Pedro Lenza $^{324}$.

Assim, segundo o estado atual da legislação, acompanhamos o posicionamento adotado, em maioria, pelos membros da Segunda Seção do STJ, no sentido de que estão "a Capital do Estado e o Distrito Federal em planos iguais, sem conotação específica para o Distrito Federal" (CC 17532 e 17533) ${ }^{325}$.

\footnotetext{
322 Código do Consumidor Comentado cit., p. 426. Na mesma linha é a lição de Vigliar (Interesses individuais homogêneos e seus aspectos polêmicos cit., p. 71) e de Luiz Paulo da Silva Araújo Filho (Ações coletivas cit., p. 138).

${ }^{323}$ Demandas coletivas e os problemas emergentes da práxis forense cit., pp. 15/25, especialmente pp. 19/20; Código Brasileiro de Defesa do Consumidor comentado cit., p. 147.

${ }^{324}$ Teoria geral da ação civil pública cit., $3^{a}$ ed., pp. 289/292.

${ }^{325}$ Na doutrina: Aluísio Mendes, Ações coletivas cit., pp. 244/245; Leonel, Manual do Processo Coletivo cit., p. 228; Mazzilli, A defesa dos interesses difusos em juízo cit., $20^{\mathrm{a}}$ ed., p. 270.
} 
Mas, em oportuna reforma do Código de Defesa do Consumidor ou em codificação dos processos coletivos, nada obsta seja adotada a competência exclusiva do foro do Distrito Federal no que respeita aos danos nacionais. Em realidade, seria até de bom alvitre a eleição de critério que, ao invés de dispersar, possa concentrar a competência em um único foro ${ }^{326}{ }_{-}^{327}$, facilitando a solução prima facie dos fenômenos da conexão, continência ou litispendência. Aliás, essa já foi a opção do Anteprojeto de Código Brasileiro de Processos Coletivos, produzido por membros do Instituto Brasileiro de Direito Processual, conforme redação do art. 22 da versão apresentada ao Ministério da Justiça em dezembro de 2006.

Com opinião contraposta, Elton Venturi ${ }^{328}$ assevera que a indesejável proliferação de demandas coletivas idênticas, com desfechos diferentes em função da variedade de órgãos julgadores, não é fruto da regra de competência concorrente entre Capitais dos Estados e Distrito Federal, mas sim da deficiência burocrática e estrutural do Judiciário, que não permite com facilidade a reunião dos feitos conexos, o que leva o autor a propor que não seja acolhida a supressão da competência da Capital dos Estados.

Conquanto a primeira observação seja verdade, não podemos esquecer que, no plano da fixação abstrato de competência em matéria de ação coletiva, merece prevalecer critério centralizador para, tanto quanto possível, obstar a escolha aleatória do foro competente pelo autor coletivo que veicule dano de caráter nacional. Também não prevalece o argumento de Elton Venturi sobre a vulneração do princípio federativo com a prioridade dada ao foro do Distrito Federal em detrimento das Capitais dos Estados.

Ocorre que as regras sobre competência territorial, servindo para distribuir o exercício do poder jurisdicional - que é uno - não estão furtando poderes das unidades

\footnotetext{
${ }^{326}$ Concentração de competência é o escopo do Código Modelo de Processos Coletivos para a IberoAmérica, Comentários ao Código Modelo de Processos Coletivos cit., p. 205. Essa concentração previne o chamado forum shopping, ocorrência da experiência norte-americana, lembrada por Carlos Alberto de Salles, na qual o demandante escolhe o foro no qual sabe que obterá melhores resultados (cf. Anteprojeto de nova lei da Ação Civil Pública - Propostas do Ministério Público de São Paulo, São Paulo, APMP, 2009, p. 19).

${ }^{327}$ Sobre a observação de Aluísio Mendes, "A designação de um único foro, num país com oito milhões e quinhentos mil quilômetros quadrados e contingente populacional de cerca de 190 milhões de habitantes, representaria, sim, barreira instransponível, desestímulo ou medida encarecedora, para que a maioria das entidades espalhadas pelo Brasil afora pudesse ajuizar a respectiva ação" (cf. Ações coletivas cit., p. 245), repisada por Elton Venturi (A competência jurisdicional na tutela coletiva cit., p. 110): para nós, ela é superada por outra perspectiva. Na medida em que a entidade não detenha suporte financeiro para o manejo de ação coletiva na Capital do país, evidencia-se a sua carência de representatividade adequada. Assim, problema dessa ordem, que sonega legitimidade ao ente desprovido de aptidão financeira à altura da magnitude do dano nacional, não pode justificar restrição ao ideal de foro centralizador da competência. ${ }^{328}$ A competência jurisdicional na tutela coletiva cit., pp. 108/109.
} 
federativas. O poder jurisdicional é atributo do Estado-juiz e não de cada um dos Estados membros da federação.

Ao ensejo dessa sugestão (para oportuna reforma ou codificação, como dito), é aberta uma porta para um esclarecimento. Pelo que se expôs acima, no tratamento conferido ao dano regional e nacional a respeito da competência, facilmente se percebe que fica infirmada a louvável intenção de maior proximidade geográfica possível entre o órgão julgador e o local do dano. Isso acontece justamente porque, se o propósito é molecularizar a solução do litígio massificado, a maior amplitude do dano cedo ou tarde importaria a opção por apenas um dos vários juízos competentes. Então, se é incontornável um relativo distanciamento geográfico ${ }^{329}$, optou-se pelo foro da Capital dos Estados ou do Distrito Federal de forma a facilitar tanto o acesso à justiça quanto o exercício do direito de defesa pelo réu da ação coletiva ${ }^{330}$.

\footnotetext{
${ }^{329}$ Distanciamento este que, embora não ideal, tem de seu lado o atual estado evolutivo dos meios de comunicação e os tipos de prova mais relevantes nos processos coletivos, como observa Alberto Benítez (Comentários ao Código Modelo de Processos Coletivos cit., p. 208).

${ }^{330}$ Nesse sentido, ao comentar o art. $9^{\circ}$ do Código Modelo de Processos Coletivos para a Ibero-América, Luiz Manoel Gomes Júnior observa que a opção pela competência do foro da Capital, ao passo que distancia o juízo do local do dano, atua "em benefício de uma justiça centralizadora" (Comentários ao Código Modelo de Processos Coletivos cit., p. 205).
} 


\section{Prova}

\section{1. Ônus de provar e inversão}

Até aqui já ficou claro que o tratamento processual que precisa ser dedicado às ações coletivas é de tal forma sui generis que alguns dos preceitos basilares do processual civil tradicional devem ser revisitados. Neste passo é que as regras de distribuição dos ônus da prova representam capítulo importante em matéria de ações coletivas.

Sem dúvida, a inovação trazida pelo art. $6^{\circ}$, VIII, do CDC, é maior do que possa parecer aos olhares dos leigos. Mais do que facilitar a prova do consumidor individual, o dispositivo consagra a teoria chamada carga dinâmica do ônus da prova, que também pode beneficiar os autores coletivos.

Antes de se definir no que consiste a teoria da carga dinâmica do ônus da prova, vale uma breve digressão no desenvolvimento da doutrina processual a respeito do ônus da prova.

Na clássica lição de Carnelutti ${ }^{331}$ acerca das posições jurídicas assumidas pelos sujeitos processuais, que inspira até os dias de hoje a teoria geral do processo, ônus é a sujeição da parte ao seu próprio interesse, dela exigindo certa iniciativa para prevenir um prejuízo processual. O ônus da prova, em especial, consiste no encargo de provar atribuído à parte interessada no acolhimento de suas alegações, sob pena de se sujeitar a julgamento que lhe pode ser desfavorável.

A noção mais remota de distribuição do ônus da prova não é assim completa, pois enfatiza apenas o caráter subjetivo do encargo. Pode ser extraída do brocardo romano semper onus probandi et incumbit quit dicit, traduzido livremente na proposição: o ônus da prova incumbe a quem afirma. Essa regra de distribuição resolvia suficientemente os problemas da práxis forense romana enquanto era autorizado ao iudex não decidir, em caso de dúvida, jurando o sibi non liquere ${ }^{332}$.

\footnotetext{
${ }^{331}$ Cf. Instituciones del Proceso Civil (trad. Santiago Sentis Melendo), tomo I, Ediciones Juridicas EuropaAmerica, 1950, pp. 331/332.

${ }^{332}$ Conforme notícia histórica de Cecília Matos em obra sempre lembrada a respeito do tema (Ônus da Prova no Código de Defesa do Consumidor, dissertação de Mestrado apresentada perante a Faculdade de Direito da Universidade de São Paulo, orientador Professor Kazuo Watanabe, 1993, p. 28/29). Também sobre referência do processo romano, confiram-se: Barbosa Moreira, Julgamento e ônus da prova, in Temas Direito
} 
Contudo, a partir do instante em que a ciência processual se firmou sobre o pilar da indeclinabilidade da jurisdição, ao juiz não é mais dado proferir o non liquet e eventual incerteza em seu convencimento a partir do material probatório produzido pelas partes deve ser solucionada com base em preceitos de distribuição do ônus da prova prédeterminados ${ }^{333}$.

Iniciou-se então a teorização do aspecto objetivo do ônus da prova, encabeçada por Julius Glaser em 1883 e notabilizada pela obra de Leo Rosenberg de $1900^{334}$, que preconizava o estabelecimento de critérios objetivos que guiassem o juiz em caso de prova insuficiente ${ }^{335}$. Assim, o peso do julgamento desfavorável, em determinada questão sobre a qual penda racional ${ }^{336}$ dúvida no convencimento do magistrado, é depositado na parte que pretendia demonstrar a ocorrência dos pressupostos de fato que autorizariam a aplicação da norma objetiva invocada.

A teoria de Rosenberg foi debatida por Gian Antonio Micheli, também em obra notável sobre o tema do ônus da $\operatorname{prova}^{337}$, com atenuações apenas no modo de descrever o fenômeno: segundo Micheli, o ônus da prova é de quem almeja determinado efeito jurídico a partir do fato que dependa de prova ${ }^{338}$.

Mais adiante, Chiovenda e Carnelutti também se debruçaram sobre o tema, por sua vez, formulando os critérios que vieram a inspirar o Código de Processo Civil brasileiro de 1973, a partir da natureza dos fatos alegados pelas partes (constitutivos, impeditivos, modificativos ou extintivos) ${ }^{339}$.

Processual - Segunda Série, São Paulo, Saraiva, 1988, pp. 73/74; e Hernando Devis Echandia, Teoria General de la Prueba Judicial, tomo II, Buenos Aires, Victor P. de Zavalia, 1981, pp. 394/395 e 421.

${ }^{333}$ Preocupação com tais preceitos, em prol da segurança jurídica, passou a ser central nos estudos de processo civil e na jurisprudência do final do século XIX (cf. Hanns Prütting, Carga de la prueba y estándar probatorio: La Influencia de Leo Rosenberg y Karl Hainz Schwab para el desarrollo del moderno Derecho probatório, in Revista Ius et Praxis, Ano 16, n. 1, 2010, Talca-Chile, pp. 453/464, especialmente p. 457).

${ }^{334}$ Ano no qual o jurista defendeu sua tese de doutorado sobre ônus da prova, intitulada Die Beweislast (cf. Hanns Prütting, cit., p. 458).

335 “Con ella se preparó la idea fundamental de la carga de la prueba por el legislador como un riesgo distribuido y, por tanto, garantizador de la seguridad jurídica” (cf. Hanns Prütting, Carga de la prueba cit., p. 459).

${ }^{336}$ Isso pela consagração do sistema da persuasão racional ou do livre convencimento motivado.

${ }^{337}$ Gian Antonio Micheli, L'onere della prova, Padova, Cedam, 1966, p. 494/495.

${ }^{338} \mathrm{Na}$ América do Sul, para uma síntese das diversas opiniões doutrinárias em torno do assunto, e para uma clara distinção entre obrigação e ônus processual, vide Echandia, op. cit., pp. 393 e seguintes, para quem o ônus da prova é "una facultad o poder de obrar libremente en beneficio propio" (p. 409).

339 Alfredo Buzaid, Do ônus da prova, in Revista de Direito Processual Civil, São Paulo, 1964, vol. 4, pp. 20/21, apud Débora de Oliveira Ribeiro, Inversão do ônus da prova no Código de Defesa do Consumidor, dissertação de Mestrado apresentada perante a Faculdade de Direito da Universidade de São Paulo, orientador Professor José Ignacio Botelho de Mesquita, 2005, p. 12. 
Desde então, ficou assente na doutrina processual, acolhida pelos juristas brasileiros $^{340}$, que o ônus da prova, pelo aspecto subjetivo, atua como estímulo às partes para apresentarem a prova das quais estão encarregadas (momento de produção da prova), e, pelo aspecto objetivo, consiste em regra de julgamento (momento de valoração da prova), pois conduz ao pronunciamento desfavorável à parte que deixou de fornecer elementos idôneos para o pleno convencimento do magistrado.

Essa formulação seria suficiente suposto que, em todo e qualquer processo, as partes dispusessem de iguais condições materiais, econômicas e técnicas para produzir a prova que lhe interessa. Mas especialmente na sociedade contemporânea, de conflitos de massa, surgidos em função de dano produzidos em alta escala por agentes mais poderosos do que as vítimas, restou frustrada a utopia de igualdade substancial das partes.

Com essa percepção, que veio acompanhada de correntes de publicização do processo $^{341}$, é que a doutrina processual contemporânea passou a cultivar a teoria da carga dinâmica da prova, mencionada no início deste capítulo. Na América do Sul, o berço da teoria é a Argentina, onde Jorge W. Peyrano e Julio O. Chiappini ${ }^{342}$ preconizaram a imposição da carga da prova à parte que tivesse melhores condições de produzi-la, e Augusto M. Morello ${ }^{343}$, mais recentemente, defendendo uma visão solidarista do ônus da prova.

Por isso, na premissa de que a aplicação do rígido modelo de distribuição do ônus da prova não assegura a decisão mais justa, o legislador brasileiro da década de 1990 instituiu mecanismos de garantia do efetivo acesso à justiça, dentre eles a inversão do ônus da prova em favor do consumidor.

\footnotetext{
${ }^{340}$ V. todos: Luiz Eduardo Boaventura Pacífico, O ônus da prova no Direito Processual Civil, São Paulo, Revista dos Tribunais, 2000, pp. 131 e 135.

${ }^{341}$ Descrita e criticada por Juan Montero Aroca, publicado em italiano Il processo civile "sociale" como strumento di giustizia autoritaria, in Rivista di Diritto Processuale, 2004, 2, pp. 553/579, em espanhol in Actualidad Civil, 2004, março, segunda quinzena, n. 6, pp. 597/619; disponível em <http://egacal.educativa.com/upload/JMA_Montero01.pdf>, acesso em 6/11/2011. Também repudiando a teoria das cargas dinâmicas da prova, vide Adolfo Alvarado Velloso, La prueba judicial (reflexiones críticas sobre la confirmación procesal), Valência, Tirant to Blanch, 2006, pp. 48/52.

342 Jorge W. Peyrano e Julio O. Chiappini, Lineamientos de las cargas probatórias “dinamicas”, El Derecho, Buenos Aires, tomo 107, 1984, apud Débora de Oliveira Ribeiro, cit., pp. 127/130.

${ }^{343}$ Para o autor, as regras estáticas de distribuição do ônus da prova pressupõem uma ótica individualista do processo, que não mais convive harmonicamente com a busca pelo processo justo e eficiente, no qual deve haver "la conjugación de la labor de los sujetos procesales, a los cuales, sin exclusión, les incumbe en concreto hacerlo adecuadamente, queremos decir, a través de una actitud útil según sus posibilidades reales de actuación, lo que significa el no incurrir en una posición abusiva por omisión" (cf. La prueba - tendencias modernas, Buenos Aires, Abeledo-Perrot, 1991, pp. 57/64).
} 
A inversão aparece em duas modalidades no Código de Defesa do Consumidor: a primeira, no já mencionado art. $6^{\circ}$, VIII, determinada a critério do juiz (ope iudices), e a segunda, no art. 38, que impõe ao patrocinador da publicidade, na qualidade de réu, o ônus de provar a veracidade e a correção da informação veiculada (ope legis).

A teor do art. $6^{\circ}$, VIII, do CDC, há dois pressupostos para o inversão do ônus da prova, a verossimilhança das alegações do consumidor e a sua hipossuficiência.

Segundo a maioria da doutrina e copiosa jurisprudência do STJ, os dois pressupostos não são cumulativos ${ }^{344}$, em razão do emprego da partícula ou na redação do texto legal. Mas, a opinião divergente de Cândido Rangel Dinamarco ${ }^{345}$ e Antonio Gidii ${ }^{346}$, com a qual concordamos, aponta que a verossimilhança é sempre exigível, sob pena de transformar o mecanismo da inversão em pesado, e às vezes invencível, encargo para o fornecedor.

Em notável precedente da lavra da Ministra Nancy Andrighi, observou-se que: "No que diz respeito à verossimilhança, o Tribunal afastou-a ponderando que "não é razoável conceber que o autor, que já havia adquirido veículo da mesma marca, e que conhecia todas as suas características, não lesse os prospectos do modelo novo, as propagandas - poderia também ler o manual de instruções que acompanhava todo e qualquer veículo novo - para saber das tecnologias que acompanhavam o carro adquirido' (fl. 702). Assiste-lhe razão nesse raciocínio. A inversão do ônus da prova não pode se prestar a transmitir ao fornecedor de produtos ou serviços a incumbência de produzir a contraprova de fato que a experiência comum mostra desarrazoado" (REsp 1021261/RS, $3^{\text {a }}$ Turma, julgado em 20/04/2010, DJe 06/05/2010).

Ao lado disso, entendemos que a exigência da hipossuficiência, sempre em adição à verossimilhança, resolve o impasse surgido quando também as alegações do fornecedor são verossímeis. Não fosse assim, o legislador teria taxado com maior valor a

\footnotetext{
${ }^{344}$ Nesse sentido: Watanabe, Código Brasileiro de Defesa do Consumidor comentado cit., p. 8, Leonel, Manual do Processo Coletivo cit., p. 364, Cecília Matos, op. cit., pp. 196/197; Arruda Alvim, Código do Consumidor Comentado cit., p. 69; Bedaque, Direito e processo cit., pp. 53/54; Marcelo Abelha Rodrigues, A distribuição do ônus da prova no Anteprojeto do Código Brasileiro de Processos Coletivos, in Direito Processual Coletivo e o anteprojeto de Código Brasileiro de Processos Coletivos cit., pp. 244/253, notadamente p. 249; Mazzilli, A defesa dos interesses difusos em juízo cit., 20ª ed., cit., pp. 175/176; Nelson Nery Junior, Aspectos do Processo Civil no Código de Defesa do Consumidor, in Revista de Direito do Consumidor, vol. I, janeiro de 1992, pp. 200/221, notadamente p. 221; e João Batista Lopes, A prova no direito processual civil, $2^{\mathrm{a}}$ ed., São Paulo, Revista dos Tribunais, 2002, p. 50.

${ }^{345}$ Instituições de Direito Processual Civil, vol. III, 6 a ed., São Paulo, Malheiros, 2009, p. 79.

${ }^{346}$ Aspectos da Inversão do Ônus da Prova no Código do Consumidor, in Genesis - Revista de Direito Processual Civil, Curitiba, setembro a dezembro de 1996, pp. 583/584.
} 
verossimilhança das alegações do consumidor em detrimento da verossimilhança das alegações do fornecedor, raciocínio que afronta o princípio da igualdade das partes.

Por sua vez, a hipossuficiência é traduzida pela doutrina como vulnerabilidade $e^{347}$, que retrata a posição do consumidor que não detém possibilidade técnica de produzir a prova, em razão de falta de conhecimento específico ou distanciamento com a situação de fato que originou o dano. Aliás, como bem adverte Antonio Gidi ${ }^{348}$, não basta a demonstração da vulnerabilidade do consumidor, pois a inversão só é autorizada se relacionada à posição de vulnerabilidade frente ao objeto da prova.

Assim, no caso concreto mencionado (REsp 1021261/RS), de aquisição pelo consumidor de veículo, em que a controvérsia residia na suposta falta de informação sobre a existência de modelo mais luxuoso do que o adquirido, a vulnerabilidade não influenciou a produção da prova e, por conseguinte, não justificou a inversão do ônus: "A matéria em discussão - compra de um automóvel de luxo - já afasta por si só qualquer discussão quanto à hipossuficiência econômica. A hipossuficiência técnica, por sua vez, que também pode ser abordada sob o ponto de vista do acesso à informação, converge para a matéria tratada acima, quando se falou da verossimilhança: não é razoável supor que alguém que já possui um automóvel de luxo e que pretende trocá-lo por outro, com alto dispêndio financeiro, não se informe ao menos quanto aos modelos disponíveis”.

A propósito, a vulnerabilidade não é atributo exclusivo do consumidor individual e poderá estar presente no autor coletivo ${ }^{349}$, desde que, como afirmado acima, a alegação objeto da prova - que se deixou de produzir - esteja relacionada a conhecimento técnico específico dominado pelo fornecedor.

$\mathrm{Na}$ jurisprudência do STJ, não consta que esse nexo venha sendo considerado nos julgados recentes, os quais vêm admitindo a inversão do ônus da prova em

\footnotetext{
${ }^{347}$ V. por todos: Watanabe, Código Brasileiro de Defesa do Consumidor comentado cit., p. 10.

${ }^{348}$ Aspectos da inversão do ônus da prova cit., p. 586.

${ }^{349}$ Ricardo de Barros Leonel registra que isso ocorre em função da "interação dos diplomas que tratam da defesa dos interesses metaindividuais" (op. cit., p. 367), e desde que presentes os pressupostos específicos que determinam a incidência da regra (p. 368). Mazzilli expõe que a hipossuficiência deve ser aferida no lesado e não no seu substituto processual (A defesa dos interesses difusos em juízo cit., p. 176). Com todo acatamento, esse raciocínio não nos convence já que o titular do direito à prova, na relação processual em ação coletiva, será o substituto e é ele quem deve ostentar a posição de vulnerável para se valer do benefício da inversão do ônus da prova. Em sentido contrário, Teresa Arruda Alvim afirma que o Ministério Público, na qualidade de autor coletivo, neutraliza qualquer hipossuficiência de produção de provas (Reflexões sobre o onus da prova, in Processo civil: estudos em comemoração aos 20 anos de vigência do Código de processo civil, São Paulo, Saraiva, 1995, pp. 245/250).
} 
ação coletiva, sob o mero fundamento de se tratar de relação consumerista em que se deve promover a máxima facilitação da produção da prova em favor dos interesses em jogo. No nosso entender, esse entendimento subverte a regra da inversão do ônus da prova, idealizada para equilibrar as condições das partes no processo, e acaba por impor encargo às vezes insuperável sobre o fornecedor.

Especialmente no caso do Ministério Público, que detém poderes investigatórios, entendemos que o deferimento da inversão do ônus da prova deve ser cuidadoso, devendo sempre ser lembrado o necessário nexo entre a prova não produzida e a deficiência técnica do órgão ou entidade que atua na tutela do consumidor ${ }^{350}$.

Também objeto de polêmica em tema de inversão do ônus da prova é saber qual o momento processual adequado para decidi-la. Tradicionalmente, por se tratar de regra de julgamento, a inversão do ônus da prova é matéria adiada para a fase decisória do processo, isto é, na ocasião de se proferir a sentença ${ }^{351}$.

Em contraposição, firmou-se entendimento doutrinário resistindo à surpresa que pode ser causada à parte com a inversão do ônus da prova relegada ao momento da sentença, o que, segundo essa corrente, afrontaria o direito de defesa do réu. Acompanham essa tese vozes de peso $^{352}$, fundadas em suma: (i) na estreita ligação entre o aspecto objetivo do ônus ao aspecto subjetivo, (ii) no atual esquema que confere ao juiz poderes instrutórios que lhe permitem gerir o objeto da prova, e (iii) no fato de ser inversão ope judices, ou seja, não ordenada previamente por lei.

\footnotetext{
${ }^{350}$ A título de referência pela inversão do ônus da prova em favor do Ministério Público: REsp 951.785/RS, Rel. Min. Luis Felipe Salomão, 4 ${ }^{\mathrm{a}}$ Turma, j. 15/02/2011; REsp 1253672/RS, Rel. Min. Mauro Campbell Marques, $2^{\text {a }}$ Turma, j. 02/08/2011. Identificamos que foi corretamente aplicada a regra da inversão em precedente envolvendo associação de defesa da saúde do fumante e fabricantes de cigarros onde se decidiu: "Hipótese em que a ré/recorrente está muito mais apta a provar que a nicotina não causa dependência que a autora/recorrida provar que ela causa” (REsp 140.097/SP, Rel. Min. Cesar Asfor Rocha, $4^{\mathrm{a}}$ Turma, j. 04/05/2000).

${ }^{351}$ Vide nota 344 e mais especificamente Cecília Matos, cit., p. 206 e 210/211; Kazuo Watanabe, cit., pp. 10/12; Bedaque, Direito e Processo cit., p. 54; Dinamarco, Instituições de Direito Processual Civil cit., vol. III, pp. 82/83; Araújo Cintra, Comentários ao Código de Processo Civil, vol. IV, 2a ed., Rio de Janeiro, Forense, 2003, p. 25; Boaventura Pacífico, O ônus da prova cit., pp. 159/160; Leonel, Manual do Processo Coletivo cit., pp. 365/366; João Batista Lopes, A prova no direito processual civil cit., p. 51; e Swarai, Poderes do juiz nas ações coletivas cit., p. 84.

${ }^{352}$ Vide: Gidi, Aspectos da Inversão do Ônus da Prova no Código do Consumidor cit., p. 587; Eduardo Cambi, A Prova Civil - Admissibilidade e Relevância, São Paulo, Revista dos Tribunais, 2006, pp. 317/318; Mazzilli, A defesa dos interesses difusos em juízo cit., p. 177; Débora de Oliveira Ribeiro, Inversão do Ônus da Prova cit., p. 79/81; Didier e Zaneti, Curso de Direito Processual Civil cit., p. 322; Bruno Freire e Silva, A inversão judicial do ônus da prova no Código de Defesa do Consumidor, e Cláudio Cintra Zarif, Ônus da prova nas ações coletivas, ambos in Aspectos Processuais do Código de Defesa do Consumidor (coord. Fabiano Carvalho e Rodrigo Barioni), vol. I, São Paulo, Revista dos Tribunais, 2008, pp. 19 e 42.
} 
Em profundo estudo sobre o direito à prova, o Professor Flávio Luiz Yarshell se posiciona ao lado dessa vertente doutrinária, adicionando a esses argumentos o princípio da confiança legítima, que pressupõe prévia e clara atribuição do ônus da prova às partes, e a exigência de uma atividade instrutória leal, sintonizada assim com as idéias de cooperação entre as partes e o juiz no exercício do contraditório ${ }^{353}$.

Nos tribunais, da mesma forma, o debate dividiu opiniões durante essas duas primeiras décadas da vigência do CDC. Em recente julgado, afetado à Segunda Seção do STJ, para sanar a divergência entre Terceira e Quarta Turmas, ficou assentado que "A inversão 'ope judicis' do ônus probatório deve ocorrer preferencialmente na fase de saneamento do processo ou, pelo menos, assegurando-se à parte a quem não incumbia inicialmente o encargo, a reabertura de oportunidade para apresentação de provas" (REsp 802.832/MG, Rel. Ministro Paulo de Tardo Sanseverino, julgado em 13/04/2011, vencidos os Ministros Vasco della Giustina e Sidnei Beneti).

Ousamos defender que desfecho tão extremo para a polêmica não era imprescindível. A sugestão da doutrina ${ }^{354}$, de que o juiz alertasse os contraditores ao início da instrução para a possibilidade de, em tese, ser invertido o ônus da prova, apontando precisamente quem seria o prejudicado na ausência da prova, já remediaria o problema. Não se falaria de surpresa da parte com a inversão e o alerta serviria de suficiente estímulo ao engajamento probatório, sem olvidar, portanto, do aspecto subjetivo do ônus da prova.

Em se tratando de regra de julgamento, a distribuição do ônus da prova não se insere no objeto do processo. Assim como não se decide sobre o emprego do método dedutivo ou do método indutivo, por exemplo, o procedimento intelectual do qual o juiz lançará mão no momento da sentença, em caso de insuficiente grau de certeza no seu convencimento, não é passível de decisão.

Além disso, apenas ao final da instrução - que coincide com a fase decisória - é que o juiz conhecerá as deficiências no material probatório coligido pelas partes. Desse modo, não nos parece possível proferir juízo a respeito de incerteza que sequer existe quando a prova ainda não está formada.

\footnotetext{
${ }^{353}$ Cf. Flávio Luiz Yarshell, Antecipação da prova sem o requisito da urgência e direito autônomo à prova, São Paulo, Malheiros, 2009, pp. 92/93. Também lembrando "o aspecto ético que deve estar presente no processo, como instrumento de jurisdição", quando se pensa em atribuição dinâmica do ônus da prova, v.: Yarshell, Tutela coletiva e deveres em matéria probatória, in Em defesa de um Novo Sistema de Processos Coletivos cit., p. 233.

${ }^{354}$ Vide nota 351.
} 
Por tudo isso, reafirmamos que, em nossa opinião, o ato pelo qual o juiz opta - e decide - pela inversão do ônus da prova é o sentenciamento, não sendo de se descartar a conveniência - mas não necessidade - de alertar as partes da possibilidade daquela inversão.

Assim, mais nítida fica a distinção lembrada por Ada Pellegrini Grinover ${ }^{355}$ entre a inversão do ônus da prova e o respectivo ônus financeiro. Se o primeiro se refere a regra de julgamento, os custos com a produção da prova não podem ser antecipadamente invertidos a pretexto da inversão do ônus de provar.

${ }^{355}$ Cf. Código Brasileiro de Defesa do Consumidor comentado cit., 10a ed., pp. 13/16. Na mesma linha: "Se não realizada a prova, por falta de pagamento das despesas, a insuficiência do conjunto probatório poderá determinar a incidência das regras de distribuição do respectivo ônus, correndo as partes esse risco. Isso não significa, todavia, que a inversão do ônus acarrete a automática irresponsabilidade pelo custo da prova. Quem quiser produzi-la, tenha ou não o ônus de fazê-lo, deve arcar com as despesas" (AI n ${ }^{\circ} 1.002844-1,1^{\circ}$ TACSP, 12a Câmara, j. 10.4.2001). 


\section{Coisa julgada}

\subsection{Conceito de coisa julgada e distinção entre efeitos da sentença e autoridade da coisa julgada}

É sabido que o instituto da coisa julgada tem fundamento em razões políticas, de estabilização e segurança das relações jurídicas, e sociais, de eliminação dos conflitos. Assim são as clássicas lições de Eduardo Couture: "La cosa juzgada es, en resumen, una exigencia política y no propiamente jurídica: no es de razón natural, sino de exigencia práctica. Sin embargo, como ya se ha anticipado, la evolución legislativa es cada día más acentuada hacia una marcha rápidamente acelerada en busca de una sentencia que decida de una vez por todas y en forma definitiva el conflicto pendiente" ${ }^{\text {356 }}$.

Apesar dessa intensa carga política, o alcance jurídico da coisa julgada sempre foi pano de fundo para intensos debates pela doutrina processual. Em tempos recentes, responsável por precisa depuração do conceito de coisa julgada, sem dúvida, foi Enrico Tullio Liebman ${ }^{357}$.

Com princípio nos estudos de Chiovenda, Liebman defendeu uma ruptura entre as noções de efeito e de conteúdo da sentença ${ }^{358}$, que se sobrepunham na tradição da doutrina germânica. Assumindo que o provimento judicial não se esgota em seu caráter declaratório, como se convenciam os germânicos, a tese liebmaniana agregou a autoridade da coisa julgada também às demais modalidades de sentença ${ }^{359}$.

De acordo com Liebman, a eficácia da sentença atua independentemente do trânsito em julgado e é inerente à atividade potestativa do juiz, enquanto órgão do estatal. Já a autoridade da coisa julgada opera sobre o comando emergente da sentença, tornando imutáveis e indiscutíveis, para as partes do processo, seus efeitos de cunho declaratório, condenatório ou constitutivo ${ }^{360}$. Em outras palavras, a autoridade da coisa julgada é uma

\footnotetext{
${ }^{356}$ Cf. Fundamentos del derecho procesal civil, $3^{\mathrm{a}}$ ed., Buenos Aires, Depalma, 1958, pp. 407/408.

357 Tanto que, conforme anota José Rogério Cruz e Tucci, no entender de Edoardo Ricci, “A doutrina posterior à tese de Liebman dividiu-se em duas fileiras contrapostas: os liebmanianos, de um lado, e os defensores da tradicional definição da coisa julgada como efeito declaratório, de outro" (cf. Limites subjetivos da eficácia da sentença e da coisa julgada civil, São Paulo, Revista dos Tribunais, 2007, p. 86).

358 Cf. Eficácia e autoridade da sentença (tradução de Alfredo Buzaid, Benvindo Aires e notas de Ada Pellegrini Grinover), $3^{\mathrm{a}}$ ed., Rio de Janeiro, Forense, 1984, p. 5.

359 op. cit., pp. 15 e 27.

360 op. cit., p. 54.
} 
qualidade dos efeitos da sentença transitada em julgado ${ }^{361}$, qualidade essa que fica represada na relação entre as partes para não prejudicar direito de terceiro.

Atuando na realidade dos fatos, como qualquer outro ato jurídico, e em especial como resultado do poder jurisdicional do Estado, a sentença emana seus efeitos naturalmente erga omnes, pois, no entender de Liebman, é "a eficácia natural da sentença que não conhece, como se disse, limitação subjetiva" ${ }^{362}$. Assim, Liebman destacou a diferença entre extensão subjetiva dos efeitos da sentença e limites subjetivos da coisa julgada.

Então, o enunciado de Wach, de que vale para todos a sentença pronunciada entre legítimos contraditores, é até verdadeiro em essência, mas se torna refratário em face de relações intersubjetivas complexas, envolvendo terceiros que não participaram do processo. Explicando o fenômeno das ações concorrentes (v.g. impugnação de sócio a deliberação assemblear), Liebman ${ }^{363}$ observa que a procedência do pedido, por iniciativa de apenas um dos legitimados, até socorre os demais sujeitos da relação (eficácia natural da sentença), mas não obsta as ações dos terceiros e legitimados concorrentes, que estão além dos limites subjetivos da coisa julgada.

Essas observações, grosso modo, resumem o pensamento de Liebman sobre a eficácia da sentença e a autoridade da coisa julgada, o qual inspirou o legislador brasileiro na elaboração do Código de Processo Civil de 1973, conforme denuncia a sua Exposição de Motivos ${ }^{364}$.

Longe de renegar as ideias de Liebman, em especial sobre a diferença entre a imutabilidade da sentença e a sua eficácia, Barbosa Moreira encarregou-se de esclarecer que não são os efeitos da sentença que se tornam imutáveis com o trânsito em julgado, mas

\footnotetext{
${ }^{361}$ Concordando com esse raciocínio, v.: Ovídio A. Baptista da Silva, Sentença e coisa julgada - ensaios, Porto Alegre, Sergio Antonio Fabris, 1979, p. 104; José Frederico Marques, Instituições de Direito Processual Civil, vol. IV, Campinas, Millennium, 2000, p. 348; Cândido Rangel Dinamarco, Instituições de Direito Processual Civil cit., 6a ed., vol. III, p. 300; Teresa Arruda Alvim Wambier e José Miguel Garcia Medina, O Dogma da coisa julgada - hipóteses de relativização, São Paulo, Revista dos Tribunais, 2003, pp. 19/23; Antonio Gidi, Coisa julgada e litispendência cit. pp. 104/107.

362 Op. cit., p. 129.

${ }^{363}$ Ações concorrentes, in Eficácia e autoridade cit., pp. 226/227.

364 "O projeto tentou solucionar esses problemas, perfilhando o conceito de coisa julgada elaborado por Liebman e seguido por vários autores nacionais”.
} 
precisamente a "norma jurídica concreta" emanada pelo juiz para disciplinar a situação concreta levada a seu conhecimento ${ }^{365}$.

Mais adiante, outro nome notável da doutrina nacional é José Ignacio Botelho de Mesquita. Seu mérito foi desvendar a diferença entre efeitos da sentença (como alterações produzidas por ela para foro do processo, de natureza declaratória, condenatória ou constitutiva) e conteúdo da sentença (que consiste na manifestação de vontade da autoridade estatal a respeito da procedência ou da rejeição do pedido formulado ao Estadojuiz, isto é, no elemento declaratório que integra toda e qualquer sentença) ${ }^{366}$.

Para Botelho de Mesquita, somente o elemento declaratório da sentença é que se reveste da autoridade da coisa julgada, produzindo para as partes: a imutabilidade e a indiscutibilidade do elemento declaratório da sentença, isto é, respectivamente, a proibição de propositura de ação idêntica e a exigência de que a sentença passada em julgado seja premissa indiscutível em outro processo.

Por outro lado, no plano da eficácia, Botelho de Mesquita observou que a sentença produz efeitos erga omnes e que tais efeitos não são imutáveis ${ }^{367}$. Assim o autor explica a forma pelo qual os terceiros são afetados por uma sentença emanada inter alios: "os efeitos da sentença podem perfeitamente beneficiar ou prejudicar terceiros", mas adiciona que a imutabilidade e a indiscutibilidade da conclusão da sentença é restrita às $\operatorname{partes}^{368}$.

\subsection{Limites subjetivos da coisa julgada e a coisa julgada erga omnes}

Das linhas acima fica nítido que, aliada ao estudo da coisa julgada está a necessidade de definir seus limites subjetivos. Isso decorre da garantia fundamental ao

\footnotetext{
${ }^{365}$ Cf. Barbosa Moreira, Eficácia da sentença e autoridade da coisa julgada, in Temas de Direito Processual Civil - Terceira Séria, São Paulo, Saraiva, 1984, pp. 99/103, notadamente p. 108. No Brasil, a ideia foi acompanhada, dentre outros, pelo Professor Rodolfo de Camargo Mancuso, em Ação popular, $3^{\mathrm{a}}$ ed., São Paulo, Revista dos Tribunais, 1998, p. 237. Em sentido muito semelhante, atribuindo a qualidade de imutável à sentença, enquanto regulação das relações de direito substancial que ela decide, v. Mario Vellani, Naturaleza de la coza juzgada, Buenos Aires, Ediciones Juridicas Europa-America, 1963, p. 100.

${ }^{366}$ A coisa julgada, Rio de Janeiro, Forense, 2006, pp. 6/9 e 19.

${ }^{367}$ Op. cit., pp. 10/17. Segundo Vellani, essa eficácia erga omnes consiste nos "inevitables efectos reflejos de la cosa juzgada" que atingem os terceiros "que si tienen eventuales derechos a hacer valer, pueden acudir a la autoridad judicial con plena libertad” (cit., p. 147). Na mesma linha: Sergio Menchini, Il giudicato civile, Turim, UTET, 1988, pp. 188/189.

368 Op. cit., pp. 24/25. E acrescenta: “os titulares de ações concorrentes são sempre beneficiados pelo julgamento de procedência, porque o efeito da sentença a todos favorece. Atingido o fim a que todas as ações tendem, passa a inexistir interesse processual que justifique a propositura de novas ações; as ações concorrentes simplesmente se extinguem. Em razão disto, a extensão da coisa julgada quando a sentença julgue procedente a ação é totalmente ociosa" (p. 35).
} 
contraditório e à ampla defesa (art. $5^{\circ}, \mathrm{LV}$, da CF) que, com respeito a quem não foi parte do processo, excetua a imutabilidade da sentença transitada em julgado. Nesse passo, Barbosa Moreira ensina: "não é só a privação da liberdade ou dos bens que se subordina ao devido processo legal, mas toda e qualquer ingerência da atividade judicial na esfera das pessoas" 369 .

Assim é que a fórmula tutti sono tenuti a riconoscere il giudicato tra le parti; però non possono esserne pregiudicati (Chiovenda) resume o princípio geral que governa os limites subjetivos da coisa julgada nos ordenamentos de tradição romanística $^{370}$. Abandonando o preceito germânico da eficácia reflexa das sentenças (Wach), o enunciado de Chiovenda ${ }^{371}$ combateu a teoria da representação (Savigny), que tentava justificar a submissão do terceiro à sentença inter alios.

Para o processualista italiano, a teoria da representação é artificial pois não resolve adequadamente o problema no qual o terceiro estranho tem seu direito negado em processo no qual não participou. Ainda na Itália, trilharam o mesmo raciocínio Girolamo Monteleone $^{372}$ e Sergio Menchini e, nas palavras do último: “L'efficacia diretta ultra partes è, pertanto, coordinata al leggitimo venir meno della normale coincidenza tra le parti del processo ed i soggetti titolari del rapporto controverso",373.

Allorio também se engajou na preservação dos direitos de terceiro frente à coisa julgada, tendo elaborado obra sempre lembrada a respeito do tema (La cosa giudicata rispetti ai terzi, Milão, 1935). Mas seu raciocínio foi construído por ótica diversa, via um nexo de prejudicialidade e dependência entre as diversas relações jurídicas e um dado indispensável consistente em precisa disposição de lei excepcionado o princípio geral res inter alios iudicata aliis non praeiudicat ${ }^{374}$.

\footnotetext{
${ }^{369}$ Cf. Considerações sobre a chamada "relativização" da coisa julgada, in Temas de Direito Processual Nona Série, São Paulo, Saraiva, 2007, p. 248.

${ }^{370}$ Botelho de Mesquita, op. cit., pp. 9/10.

${ }^{371}$ Principios de Derecho Procesal Civil, tomo II, Madri, Editorial Reus, 1925, pp. 430/431.

${ }^{372}$ Girolamo A. Monteleone, I limiti soggettivi del giudicato civile, Padova, Cedam, 1978: "Si tratta del principio del contraddittorio, da intendersi non in senso formale, o peggio formalistico, ma nel senso più pieno come quel principio la cui rigorosa osservanza vale a consentire che le parti del giudizio abbiano la concreta ed effettiva possibilità di difendersi, e quindi di contribuire realmente alla formazione della sentenza che li riguarda" (p. 151).

${ }_{373}$ Cf. Il giudicato civile cit., p. 144.

${ }^{374}$ Para um resumo do pensamento de Allorio, vide: Trocker, Enrico Allorio e la dottrina della riflessione della coisa giudicata rispetto ai terzi, in Rivista di Diritto Processuale, vol. 56, n. 2, abril a junho de 2001, pp. 339/375, mais precisamente p. 358. No Brasil, em sentido muito semelhante: Ovídio A. Baptista da Silva, Sentença e coisa julgada cit., p. 115.
} 
O debate, no entanto, estava longe de se exaurir porque não raras vezes a observância do adágio res inter alios iudicata aliis non praeiudicat produzia uma incompatibilidade de julgados quando, para além de uma relação de prejudicialidade de ações, existisse concorrência de legitimados. Assim ocorre na hipótese da ação de um sócio visando à anulação de deliberação assemblear, em que o objeto do processo é único incindível, poderiam coexistir duas sentenças praticamente inconciliáveis, uma declarando a validade de assembleia e outra anulando-a.

Esse cenário colocava em risco a segurança jurídica impregnada na institucionalização da coisa julgada, já que, como já observara a Professora Ada Pellegrini Grinover: "a coisa julgada não tem escopo de evitar decisões entre si inconciliáveis, mas apenas o de evitar a incompatibilidade prática entre comandos"375.

Liebman não se conformou com o desfecho de um caso perante a Corte Suprema italiana no qual, numa tentativa de preservar a coexistência prática de julgados, a rejeição da ação proposta por um dos legitimados obstou a ação dos demais legitimados e afirmou que as ações concorrentes "não se interferem nem se hostilizam entre si, senão quando uma tenha atingido o fim comum, tirando assim às outras toda a razão de ser. Neste nexo particular que une as várias ações, deixando-as, todavia, distintas e separadas, reside a nota característica da figura das ações concorrentes. E a consequência natural e normal é que cada ação pode ser proposta independentemente e que a procedência de uma delas extingue todas as outras, ao passo que a sua rejeição não as prejudica"376.

A explicação, baseada somente no plano da eficácia da sentença e variável segundo o resultado do processo, não convenceu a todos. Segundo a proposição de Liebman, restaria ao prejudicado promover ação impugnativa da sentença; ou seja, o mestre italiano admite que ao terceiro só cabe combater a coisa julgada. Ora, a doutrina enxergou aí uma verdadeira expansão ultra partes dos limites da coisa julgada, atuando, porém, secundum eventum litis.

\footnotetext{
375 Cf. Ada Pellegrini Grinover, Ações concorrentes - Pluralidade de partes legítimas à impugnação de um único ato, in Eficácia e autoridade da sentença cit., p. 243.

${ }^{376} \mathrm{Cf}$. Eficácia e autoridade da sentença cit., p. 232. Acompanhando o mestre italiano, Botelho de Mesquita escreveu linhas similares: "os titulares de ações concorrentes são sempre beneficiados pelo julgamento de procedência, porque o efeito da sentença a todos favorece" (cf. A coisa julgada cit., p. 35); por sua vez, segundo o autor, a sentença de improcedência não é dotada de eficácia alguma (op. cit., p. 28). Da mesma forma, dando ênfase à repercussão da eficácia natural da sentença em ações concorrentes: Ovídio A. Baptista da Silva, Sentença e coisa julgada cit., pp. 119/120.
} 
Sobre o tema, Sergio Menchini enunciou que: "Tale efficacia secundum eventum litis è del tutto rispetossa del diritto di difesa del terzo, che non trae alcun svantaggio da una erronea o negligente difesa del proprio concreditore o coobbligato",377.

Barbosa Moreira ${ }^{378}$ também esclareceu, em estudo dedicado ao litisconsórcio unitário, que a eficácia do julgado sobre o colegitimado ausente - em relação unitária - é produzida, positiva ou negativamente, sempre com o mesmo alcance erga omnes, e não descarta a extensão da coisa julgada secundum eventum litis.

Aliás, não era inédita para o processo civil brasileiro de índole individual a coisa julgada ultra partes, como se observa do art. $42, \S 3^{\circ}$, do CPC, que regulamenta a eficácia da sentença quando há alienação do objeto litigioso: "A sentença, proferida entre as partes originárias, estende os seus efeitos ao adquirente ou ao cessionário".

Como, outrossim, lembrou a Professora Ada Pellegrini Grinover ${ }^{379}$, a imprecisão desse pensamento de Liebman repousa no fato de que nem sempre há convergência de interesses entre os titulares de um direito incindível, de forma a não lhes ser indiferente a sentença de improcedência.

A circunstância é igualmente verdadeira quando se fala de direitos transindividuais e, neste âmbito, José Rogério Cruz e Tucci foi preciso: “A 'afinidade' axiológica entre eficácia ultra partes e tutela dos interesses coletivos ou difusos baseia-se na relevância jurídica que a coisa julgada representa para a esfera dos direitos dos sujeitos estranhos ao processo, mas que são titulares da mesma res in iudicium deducta ou de um interesse qualificado por um vínculo de prejudicialidade-dependência"380.

Aliás, opção explícita pela coisa julgada ultra partes já tinha sido feita pelo legislador da ação popular de 1965, conforme preceito contido no art. 18 da Lei n. $4.717^{381}$, em razão da indivisibilidade do bem jurídico protegido consistente no patrimônio público. O mesmo raciocínio valeria para a Lei n. 7.347/85 e, finalmente, para o Código de Defesa do Consumidor, na disciplina do regime da coisa julgada em respeito a direitos difusos e coletivos stricto sensu, que são indivisíveis por natureza.

\footnotetext{
${ }^{377}$ Cf. Il giudicato civile cit., p. 157.

${ }^{378}$ Litisconsórcio unitário, Rio de Janeiro, Forense, 1972, pp. 27/28, 144/145 e 147/149.

${ }^{379}$ Ações concorrentes cit., p. 239.

${ }^{380}$ Cf. Limites subjetivos da eficácia da sentença e da coisa julgada nas ações coletivas, in Revista de Processo, vol. 143, janeiro de 2007, pp. 42 e seguintes; disponível em Revista dos Tribunais on line.

381 “Art. 18. A sentença terá eficácia de coisa julgada oponível 'erga omnes', exceto no caso de haver sido a ação julgada improcedente por deficiência de prova; neste caso, qualquer cidadão poderá intentar outra ação com idêntico fundamento, valendo-se de nova prova".
} 
Com a inviabilidade prática de represar a eficácia da sentençca ${ }^{382}$ - e também assim a imutabilidade de seu comando - à esfera jurídica das partes presentes no processo, que não são titulares exclusivas do direito indivisível, o legislador reconheceu que a coisa julgada atua erga omnes (CDC, art. 103, inciso I) ou, na expressão equivalente quando é possível determinar o grupo atingido, ultra partes (CDC, art. 103, inciso II).

Falamos em expressão equivalente porque, tanto no regime dos interesses difusos quanto no dos interesses coletivos stricto sensu, os terceiros, aos quais a autoridade da coisa julgada pode ser estendida, são os mesmos (legitimados extraordinários); a limitação da eficácia da sentença ultra partes, na hipótese do inciso II, é natural à própria aglutinação dos titulares dos interesses coletivos stricto sensu em grupos, classes ou categorias $^{383}$.

Na forma do inciso III do art. 103 do Código do Consumidor, tratamento similar foi dedicado à coisa julgada oriunda de processo coletivo por meio do qual são deduzidos direitos individuais homogêneos, pois, há igualmente uma dissociação entre o titular do direito e o titular da ação.

Lembrando as lições de Carpi em destacável obra a respeito (L'efficacia "ultra partes" della sentenza civile), "uma delimitação excessivamente rigorosa dos limites subjetivos da coisa julgada nas ações coletivas pode constituir um obstáculo irremovível à tutela jurisdicional dos direitos superindividuais" ${ }^{384}$. Monteleone também realçou que uma releitura dos limites subjetivos da coisa julgada é imprescindível para a compreensão do fenômeno e para "adeguare il risultato del processo alle peculiarità della

\footnotetext{
${ }^{382}$ De fato, quanto se trata de direito indivisível, ocorre também a extensão ultra partes da própria eficácia da sentença, como bem observou Ada Pellegrini Grinover: "Referimo-nos aqui, à extensão ultra partes da própria coisa julgada, como qualidade da sentença e de seus efeitos (a imutabilidade)" (cf. As garantias constitucionais do processo nas ações coletivas, in Novas Tendências cit., p. 53).

${ }^{383}$ Igualando, para esse fim, as expressões erga omnes e ultra partes, v.: Gidi, Coisa julgada e litispendência cit., p. 108; Cruz e Tucci, Limites subjetivos da eficácia da sentença e da coisa julgada civil cit., p. 316; Leonel, Manual de Processo Coletivo cit., p. 291; Aluisio Mendes, Ações coletivas cit., p. 278; e Botelho de Mesquita, pois "além das demais entidades concorrentemente legitimadas, não há ninguém que tenha legitimação para discutir ou pretender discutir a conclusão da sentença dada entre as partes numa ação fundada em interesse ou direito coletivo" (op. cit., pp. 36/37). Em sentido contrário: Grinover, Código Brasileiro de Defesa do Consumidor comentado cit., p. 202, embora tenha reconhecido em linhas anteriores que: "não há diferenças entre o regime da coisa julgada nos interesses difusos e coletivos" (p. 190); e Arruda Alvim, Código do Consumidor Comentado cit., p. 466.

${ }^{384}$ Apud Gidi, Coisa julgada e litispendências cit., p. 58. No mesmo sentido: Mauro Cappelletti, Formações sociais e interesses coletivos diante da justiça civil cit., p. 154, propondo uma releitura das garantias do contraditório e da ampla defesa sob uma perspectiva do garantismo social ou coletivo; Monteleone, I limiti soggettivi del giudicato civile cit., p. 173, para quem " $\mathrm{i}$ principii considerati come $\mathrm{i}$ cardini di un giusto processo (ad es.: contradittorio, difesa, equilibrio tra i poteri del giudice e delle parti, limiti del giudicato, ecc.) dovrebbero essere abbandonati come vecchie bardature, che ostacolano l'avvento del nuovo e necessario cambiamento".
} 
situazione tutelata", diante da "perduta del monopolio dell'azione da parte del singolo 'titolare',385, que se releva um dos caracteres basilares das ações coletivas.

Mas não se poderia seguir o caminho da coisa julgada erga omnes sem a preocupação com os terceiros, inevitavelmente ausentes do processo, que compartilham do interesse indivisível articulado em juízo. Assim, a escolha dos legitimados extraordinários buscou parâmetros na experiência norte-americana da class action, centrada na representatividade $^{386}$, em decorrência da qual o membro do grupo ausente sequer é autêntico terceiro, na medida em que esteja adequadamente representado ${ }^{387}$, e se sujeita à decisão proferida na ação de grupo tanto em seu benefício quanto em seu desfavor.

Contudo, em todas as hipóteses de direitos transindividuais, a extensão erga omnes da coisa julgada mereceu temperamentos na disciplina brasileira das ações coletivas, como se verá adiante.

\subsubsection{Coisa julgada secundum eventum litis e secundum eventum probationis}

A inevitável extensão erga omnes da coisa julgada coletiva foi, em cada caso, atenuada. É o que decorre do art. 16 da Lei n. 7.347/85 e dos incisos I, II e III do art. 103 do Código de Defesa do Consumidor.

Em se tratando de direitos essencialmente coletivos, optou o legislador por aproveitar o regramento criado pela Lei da Ação Popular, adotando a coisa julgada secundum eventum litis. A imutabilidade da sentença, assim, vincula todos os legitimados coletivos, pro et contra, ressalvada a hipótese de improcedência por insuficiência de provas, quando qualquer legitimado pode repropor a demanda.

\footnotetext{
${ }^{385}$ Cf. Monteleone, I limiti soggettivi cit., pp. 126/127.

${ }^{386}$ Linda Mullenix assim descreveu: "The central characteristic of the American class action procedure is that it is representational litigation, not actual party litigation. Because the American class action rule is representational, from the outset American class action jurisprudence has been predominantly concerned with the constitutional due process protection of the interests of absents class members" (cf. Os processos coletivos nos países de civil law e common law cit., pp. 260/261).

387 'l'esplicarsi degli effeti del giudicato nei confronti di tutti gli appartenenti alla categoria rappresentata in giudizio non comporta reala eccezione al principio dei limiti soggettivi, e neppure l'irradiarsi 'ultra partes' della eficacia della sentenza, ne la esorbitanza dei poteri e dell'atto del giudice dai propri limiti intrinseci. (...) l'azione costituisce un caso estremamente interessante di adattamento dell'istituto della rappresentanza a nuove esigenze emergenti in senso alla società ed ai suoi moduli organizzativi. Per tali ragioni riteriamo che l'estensione del giudicato oltre le parti sia in questo caso frutto di illusione ottica (...). Nel processo, inoltre, viene assicurata rigorosamente la difesa di tutti, perchè condizione essenciale e preliminare all'ammissibilità dell'azione è, oltre alla comunanza delle posizioni sostanziali e processuali, quella che 'the representative parties will fairly and adequately protect the interest of the class"” (cf. Monteleone, op. cit., pp. 176/178).
} 
No contexto da ação popular, a mitigação da coisa julgada desfavorável ao interesse coletivo serve para proteger a coletividade de manobras mal intencionadas - de qualquer cidadão, isento do recolhimento inicial de custas e promovendo ação com deficiente instrução - com o objetivo de convalidar ato administrativo lesivo. Como comentou Barbosa Moreira ${ }^{388}$ a esse propósito, a desvantagem de expor o ato administrativo a inúmeras impugnações, e que podem dar causa a decisões contraditórias, é vencida pela vantagem de preservar o interesse coletivo, pensamento com o qual nos aliamos.

O mesmo raciocínio vale para os direitos coletivos que não se enquadrem na noção de patrimônio público e daí a justificativa para a coisa julgada secundum eventum litis prevista nos incisos I e II do art. 103 do CDC.

A opção não foi somente aplaudida. Desde a doutrina tradicional até os autores contemporâneos $^{389}$, é oposto o argumento de que a coisa julgada secundum eventum litis promove séria desigualdade entre as partes e impõe excessivos ônus ao réu, que precisa articular sua defesa sem a possibilidade de apresentar exceção de coisa julgada, já que no direito brasileiro não se conhece algo semelhante à collateral estoppel do direito norte-americano ${ }^{390}$.

Chegou-se também a ponderar que essa sistemática atentaria contra a segurança jurídica na medida em que se aproxima da coisa julgada secundum eventum probationis que estabiliza o comando da sentença segundo os limites da prova produzida (como ocorre normalmente no mandado de segurança, que não tem cognição exauriente) e permite o ajuizamento de tantas demandas coletivas quantas forem diversas (e, assim, novas) as provas coligidas pelo autor.

Com efeito, o inconveniente poderia ser superado com uma interpretação razoável e restritiva da autorização para o autor coletivo ajuizar a mesma demanda com

\footnotetext{
${ }^{388}$ A ação popular no direito brasileiro cit., pp. 16/17. Também elogiando o temperamento da coisa julgada erga omnes: Álvaro Mirra, A coisa julgada nas ações para tutela de interesses difusos, in Revista dos Tribunais, vol. 631, maio de 1988, p. 71 e seguintes; Mancuso, Jurisdição coletiva e coisa julgada cit., p. 317; Cambi, Coisa julgada e cognição secundum eventum probationis, in Revista de Processo, vol. 109, janeiro de 2003, p. 71 e seguintes.

389 Para referências à doutrina contrária à coisa julgada secundum eventum litis, v.: Grinover, Código Brasileiro de Defesa do Consumidor cit., p. 179, e As garantias constitucionais cit., p. 55; e Mancuso, Ação popular cit., p. 244.

${ }^{390}$ Esclarece Antonio Gidi que o fenômeno se assemelha à preclusão de questões de fato (issues of fact) que, se discutidas em amplo contraditório em processo anterior, não podem mais ser questionadas em processo posterior envolvendo as mesmas partes ou terceiros (Coisa julgada e litispendência cit., p. 232).
} 
base em nova prova. Assim como propuseram Arruda Alvim ${ }^{391}$ e Antonio Gidi ${ }^{392}$, a nova prova deve potencialmente ser a resultado diverso daquele obtido no processo anterior.

O Código Modelo de Processos Coletivos para a Ibero-América foi até mais longe, propugnando, no art. 33, parágrafo único, que: "Mesmo na hipótese de improcedência fundada nas provas produzidas, qualquer legitimado poderá intentar outra cão, com idêntico fundamento, quando surgir prova nova, superveniente, que não poderia ter sido produzida no processo", no que foi seguido pelo projeto de nova lei de ação civil pública (art. $\left.38^{393}\right)$.

A mesma regra não se aplica, contudo, ao processo coletivo que veicula direitos individuais homogêneos, conforme esboçado a seguir.

\subsection{Transporte da coisa julgada in utilibus}

$\mathrm{Na}$ dimensão coletiva dos direitos individuais homogêneos, ou seja, enquanto se busca a sentença genérica prevista no art. 95 do CDC, a coisa julgada atua pro et contra em face de todos os legitimados (extensão erga omnes, conforme capítulo 4.2 supra). É vedada, portanto, a repropositura de ação coletiva com base em nova prova.

A regra não que se extrai facilmente da dicção do art. 103, inciso III, do CDC: "erga omnes, apenas no caso de procedência do pedido, para beneficiar todas as vítimas e seus sucessores, na hipótese do inciso III do parágrafo único do art. 81 ”. O dispositivo chegou a ser lido como uma coisa julgada secundum eventum litis ${ }^{394}$, mas, com o devido acatamento, essa interpretação contraria a ratio legis, na medida em que não foi adotado o mesmo temperamento descrito nos incisos I e II.

É assim o pensamento da maioria da doutrina ${ }^{395}$, sendo destacáveis: Ada Pellegrini Grinover ${ }^{396}$, Kazuo Watanabe ${ }^{397}$, José Rogério Cruz e Tucci ${ }^{398}$ e Arruda

\footnotetext{
${ }^{391}$ Código do Consumidor comentado cit., p. 461.

${ }^{392}$ Coisa julgada e litispendência cit., p. 135.

393 "Art. 38. Na hipótese de sentença de improcedência, havendo suficiência de provas produzidas, qualquer legitimado poderá intentar ação revisional, com idêntico fundamento, no prazo de um ano contado do conhecimento geral da descoberta de prova técnica nova, superveniente, que não poderia ser produzida no processo, desde que idônea para mudar seu resultado".

${ }^{394}$ Nesse sentido: Mazzilli, A defesa dos interesses difusos em juízo cit., 20a ed., pp. 536/537.

${ }^{395}$ Gidi, Coisa julgada e litispendência cit., p. 140; Didier e Zaneti, Curso de Direito Processual Civil cit., p. 358; Luiz Paulo da Silva Araújo Filho, Ações coletivas cit., p. 171; Leonel, Manual do Processo Coletivo cit., p. 292; Luiz Guilherme Marinoni e Sérgio Cruz Arenhart, Curso de Processo Civil cit., p. 339.

${ }^{396}$ Código Brasileiro de Defesa do Consumidor comentado cit., $10^{\text {a }}$ ed., p. 203.

${ }^{397}$ Os processos coletivos nos países de civil law e common law cit., $2^{\mathrm{a}}$ ed., p. 304.
} 
Alvim $^{399}$. De fato, a conclusão não poderia ser diferente sob pena de afrontar a regra geral do art. 472 do CPC.

Em realidade, quando a lei ressalva que os titulares de direitos homogêneos não poderão ser prejudicados pela coisa julgada coletiva, pretende afirmar que o transporte da sentença coletiva para a esfera individual somente ocorrerá para beneficiar a vítima. É o que se convencionou chamar de coisa julgada in utilibus.

Será in utilibus o transporte da sentença de procedência em favor dos interessados que tenham requerido a suspensão do processo individual dentro dos 30 dias seguintes à ciência do processamento da ação coletiva ${ }^{400}$, na forma do art. 104 do CDC, ou daqueles que, mesmo sem ação individual prévia, queiram se valer do julgado coletivo mediante liquidação ou execução.

Por outro lado, excluem-se desse transporte in utilibus as vítimas que tenham intervindo no processo coletivo como litisconsortes, a contrario sensu do $\S 2^{\circ}$ do art. 103 do CDC, bem como os autores de demandas individuais que não tenham requerido a suspensão do processo de acordo com o art. 104 do CDC.

A regra é diferente daquela que vigora no sistema das ações de classe norteamericanas: enquanto no sistema brasileiro o interessado pode aderir e espontaneamente vincular-se ao julgado coletivo, na class action vale o opt out, ou seja, a opção do interessado por se excluir dos efeitos da ação coletiva ${ }^{401}$.

A consequência prática desse quadro salta aos olhos: ao invés de ampliar o espectro de indivíduos ligados à ação coletiva (e com isso otimizar a efetividade da tutela), a coisa julgada in utilibus não persuade a adesão do indivíduo ao processo coletivo.

Mas, no tempo em que editado, um dos grandes trunfos do Código do Consumidor foi a reserva do direito do terceiro, que não tenha tido notícia da ação coletiva e nem dela tenha participado. Obstáculos de toda ordem - principalmente a deficiência de

\footnotetext{
${ }^{398}$ Limites subjetivos da eficácia da sentença e da coisa julgada civil, São Paulo, Revista dos Tribunais, 2006, pp. 319/320.

${ }^{399}$ Código do Consumidor comentado cit., p. 467.

${ }^{400}$ E neste ponto discordamos da posição de Antonio Gidi (em Coisa julgada e litispendência cit., p. 198).

${ }^{401}$ Rule 23 (c) (3): "The judgment in an action maintained as a class action under subdivision (b)(3), whether or not favorable to the class, shall include and specify or describe those to whom the notice provided in subdivision (c)(2) was directed, and who have not requested exclusion, and whom the court finds to be members of the class".
} 
comunicação e de conscientização jurídica da população ${ }^{402}$ - recomendavam que o modelo da class action for damages fosse adaptado.

Vittorio Denti até dedicou algumas linhas para elogiar a opção do legislador brasileiro, e que bem resumem a sua conveniência: "il criterio della eficacia in utilibus del giudicato a favore dei terzi mi sembra meritevole di attenta considerazione nel campo della tutela degli interessi superindividuali, anche perchè consente di evitare gli ostacoli che l'efficacia ultra partes può incontrare sul piano dei diritti di difesa costituzionalmente garantiti",403.

Era justificado o cuidado com a importação da class action for damages na medida em que o ordenamento brasileiro não assimilaria imediatamente os elementos que dão suporte à coisa julgada pro et contra aos membros do grupo, quais sejam: (i) rigoroso controle de representatividade (supra, capítulo 1.5), (ii) certificação inicial da class action, decisão por meio da qual o juiz define o objeto da class action e transforma "uma massa de indivíduos amorfa em uma entidade juridicamente reconhecida"404; (iii) e notificação individual e adequada dos membros do grupo para exercerem, caso queiram, a faculdade de opt out.

No Brasil, ainda caminhamos em direção a um cenário adaptado a nossa realidade, no sentido de garantir, passo a passo: $1^{\circ}$ ) consistente gestão das informações a respeito das ações coletivas em curso e já julgadas (v.g.: banco de dados nacional que está sendo criado sob a gerência do $\mathrm{CNJ}) ; 2^{\circ}$ ) ampla divulgação do trâmite de ações coletivas, com a finalidade de comunicar adequadamente o maior número possível de interessados (visto que o edital é meio fictício e obsoleto de notificação e a comunicação pessoal pode ser absurdamente onerosa); e, por consequência, $3^{\circ}$ ) concreta oportunidade de opção pela ação coletiva ou pela iniciativa individual.

Dito de outra forma, o percurso rumo ao fortalecimento da class action for damages brasileira só se iniciou em 1990 com a edição do Código do Consumidor. E os fatores que até hoje resistem e reduzem o grau de efetividade deste tipo de ação coletiva não podem ser encarados de forma isolada. Ou seja, é incorreto atribuir a impotência da ação coletiva ao transporte da coisa julgada in utilibus para a esfera individual.

\footnotetext{
${ }^{402}$ Ada Pellegrini Grinover, Código Brasileiro de Defesa do Consumidor comentado cit., p. 179.

${ }^{403}$ Cf. Giustizia e partecipazione nella tutela dei nuovi diritti cit., p. 21.

${ }^{404}$ A expressão é de Antonio Gidi, in A class action como instrumento cit., p. 198.
} 
Nessa marcha, o traçado de nova lei de ação civil pública, do Projeto n. 8.046/2010, impulsiona positivamente a disciplina das ações coletiva, em particular pelos arts. $13^{405}, 34^{406}$ e $53^{407}$.

Por outro lado, como se verá no decorrer deste trabalho, daremos realce ao direito potestativo, inerente ao titular do direito homogêneo, em optar pela tutela coletiva e, assim, suspender o curso de sua demanda individual. Isso nos faz, destarte, discordar pontualmente da suspensão obrigatória das ações individuais face à demanda coletiva, na forma proposta pelo art. 37 do projeto, in verbis: “O ajuizamento de ações coletivas não induz litispendência para as ações individuais que tenham objeto correspondente, mas haverá a suspensão destas, até o julgamento da demanda coletiva em primeiro grau de jurisdição".

Não se nega que a suspensão obrigatória é um escape contra o indesejável trâmite conjunto de ações coletivas e individuais e, simultaneamente, um convite mais vigoroso para o indivíduo isolado não exercer o opt out. Sem dúvida, a ação coletiva evoluiria em termos de efetividade.

405 “Art. 13. Estando em termos a petição inicial, o juiz ordenará a citação do réu e, em se tratando de interesses ou direitos individuais homogêneos, a intimação do Ministério Público e da Defensoria Pública, bem como a comunicação dos interessados, titulares dos respectivos interesses ou direitos objeto da ação coletiva, para que possam exercer, até a publicação da sentença, o seu direito de exclusão em relação ao processo coletivo, sem prejuízo de ampla divulgação pelos meios de comunicação social. Parágrafo único. A comunicação dos membros do grupo, prevista no caput, poderá ser feita pelo correio, inclusive eletrônico, por oficial de justiça ou por inserção em outro meio de comunicação ou informação, como contracheque, conta, fatura, extrato bancário e outros, sem obrigatoriedade de identificação nominal dos destinatários, que poderão ser caracterizados enquanto titulares dos mencionados interesses ou direitos, fazendo-se referência à ação, às partes, ao pedido e à causa de pedir, observado o critério da modicidade do custo".

406 “Art. 34. Os efeitos da coisa julgada coletiva na tutela de direitos individuais homogêneos não prejudicarão os direitos individuais dos integrantes do grupo, categoria ou classe, que poderão propor ações individuais em sua tutela. $\S 1^{\circ}$ Não serão admitidas novas demandas individuais relacionadas com interesses ou direitos individuais homogêneos, quando em ação coletiva houver julgamento de improcedência em matéria exclusivamente de direito, sendo extintos os processos individuais anteriormente ajuizados. $\S 2^{\circ}$ Quando a matéria decidida em ação coletiva for de fato e de direito, aplica-se à questão de direito o disposto no $\S 1^{\circ}$ e à questão de fato o previsto no caput e no $\S 6^{\circ}$ do art. $37 . \S^{\circ}$ Os membros do grupo que não tiverem sido devidamente comunicados do ajuizamento da ação coletiva, ou que tenham exercido tempestivamente o direito à exclusão, não serão afetados pelos efeitos da coisa julgada previstos nos $\S \S 1^{\circ}$ e $2^{\text {o" }}$.

407 “Art. 53. O Conselho Nacional de Justiça organizará e manterá o Cadastro Nacional de Processos Coletivos, com a finalidade de permitir que os órgãos do Poder Judiciário e os interessados tenham amplo acesso às informações relevantes relacionadas com a existência e o estado das ações coletivas. $§ 1^{\circ}$ Os órgãos judiciários aos quais forem distribuídos processos coletivos remeterão, no prazo de dez dias, cópia da petição inicial, preferencialmente por meio eletrônico, ao Cadastro Nacional de Processos Coletivos. $§ 2^{\circ}$ No prazo de noventa dias, contado da publicação desta Lei, o Conselho Nacional de Justiça editará regulamento dispondo sobre o funcionamento do Cadastro Nacional de Processos Coletivos e os meios adequados a viabilizar o acesso aos dados e seu acompanhamento por qualquer interessado através da rede mundial de computadores. $\S 3^{\circ} \mathrm{O}$ regulamento de que trata o $\S 2^{\circ}$ disciplinará a forma pela qual os juízos comunicarão a existência de processos coletivos e os atos processuais mais relevantes sobre o seu andamento, como a concessão de antecipação de tutela, a sentença, o trânsito em julgado, a interposição de recursos e a execução". 
Todavia, acreditamos que o processo coletivo para a defesa de direitos homogêneos não foi concebido com o fim de se sobrepor ao direito individual da ação; pelo contrário, o instrumento veio à lume para facilitá-lo ou, em certos casos, trazê-lo de fato para a arena judicial.

Compreendemos que a regra proposta no mencionado art. 37 não anula o direito de ação do titular de direito homogêneo, mas dela intuímos que se furta do indivíduo o livre exercício do opt out, pois a sua pretensão só poderá fluir, de acordo ou não com seus legítimos e pessoais anseios de representatividade e celeridade, na medida em que esteja vinculada à ação coletiva ou, se demonstrados "graves prejuízos decorrentes da suspensão" (art. 37, § $3^{\circ}$ ).

Assim, o que seria um convite à livre adesão pode resvalar para uma via de mão única no sentido da submissão ao processo coletivo, incompatível com o antecedente histórico da ação coletiva brasileira de defesa dos direitos individuais homogêneos ${ }^{408}$.

Diferente disso, se apenas atingidos os propósitos de comunicação adequada e explícito controle de representatividade, a escolha pela via coletiva já será suficientemente incentivada e acompanhada de uma redução espontânea das iniciativas individuais.

Assim, compartilhamos da opinião de Ricardo de Barros Leonel, segundo quem: “A disciplina da opção pelo seguimento da ação individual mediante simples requerimento tornaria a solução normativa razoável. Compatibilizaria a regra com a necessidade de respeito pela garantia constituição de acesso à justiça em enfoque individual, e aprimoraria o funcionamento e os resultados do processo coletivo"409.

Em linhas desapegadas do projeto de nova lei da ação civil pública, Teori Albino Zavascki também foi enfático: “A liberdade de vinculação, assegurada ao titular, realça a natureza dos direitos individuais homogêneos: são direitos subjetivos integrados

\footnotetext{
${ }^{408}$ Em confronto com a mandatory class action (definida nos itens (b)(1) (A) e (B)), de caráter obrigatório, a class action for damages do direito norte-americano (do item (b)(3) da Rule 23) atende a um propósito de conveniência. Assim, Antonio Gidi expõe: "Como vimos quando estudamos os antecedentes históricos das class actions, por motivo de conveniência e necessidade, permitiu-se a tutela coletiva dos direitos. Abriu-se, então uma exceção ao direito dos membros do grupo de serem ouvidos pessoalmente em juízo e substituiu-se por um direito de serem ouvidos e de participarem coletivamente" (cf. A class action como instrumento cit., p. 100). ${ }^{409}$ Op. cit., p. 308.
} 
ao patrimônio de titulares certos, que sobre eles exercem, com exclusividade, o poder de disposição (...) ao contrário do que ocorre com os direitos coletivos e difusos" ${ }^{\text {,410. }}$.

\subsection{A limitação territorial da coisa julgada segundo a Lei 9.494/97}

Não são poucas as vezes em que o Poder Executivo se posiciona como vilão da tutela coletiva, em termos de efetividade. Exemplos desse tipo de atentado aos princípios do processo coletivo são alguns dispositivos da Lei n. 9.494/97, que resulta da Medida Provisória n. 1.570/97.

Na dicção de seu art. $2^{\circ}$, que alterou a redação do art. 16 da Lei 7.347/85, "A sentença civil fará coisa julgada erga omnes, nos limites da competência territorial do órgão prolator, exceto se o pedido for julgado improcedente por insuficiência de provas, hipótese em que qualquer legitimado poderá intentar outra ação com idêntico fundamento, valendo-se de nova prova".

Tempos depois, a Medida Provisória n. 2.180-35/2001 foi além, a inseriu na Lei n. 9.494 o art. $2^{\circ}$-A com o seguinte teor: “A sentença civil prolatada em ação de caráter coletivo proposta por entidade associativa, na defesa dos interesses e direitos dos seus associados, abrangerá apenas os substituídos que tenham, na data da propositura da ação, domicílio no âmbito da competência territorial do órgão prolator”.

A anomalia repousa em igualar os limites subjetivos da coisa julgada com os critérios para atribuição de competência. Ignorou-se, também, a regra basilar de que a jurisdição é una dentro do território nacional e, portanto, "todos os juízes do país são investidos desse poder, o qual é o mesmo apesar da distribuição das tarefas e atribuições"411.

Sob outro ângulo, a limitação territorial da coisa julgada é um desserviço às ações coletivas e está na contramão da almejada desobstrução do Judiciário com os conflitos de massa e resolução uniforme dos conflitos homogêneos, na medida em que estimula a propositura de mais de um processo coletivo para corrigir dano de médio ou alto grau de dispersão.

\footnotetext{
${ }^{410}$ Cf. Processo coletivo cit., p. 160. Também se ajusta a esse pensamento as palavras de Luis Paulo da Silva Araújo Filho, segundo quem: "a garantia constitucional de tutela coletiva de interesses individuais, não quer - e não pode! - evidentemente significar o desrespeito a outras garantias previstas na própria Constituição, como a da livre atuação dos próprios indivíduos, titulares dos direitos, em defesa de seus bens ou de sua propriedade (art. 5, XXII)" (Ações coletivas cit., p. 103).

${ }^{411}$ Cf. Cândido Rangel Dinamarco, Instituições de Direito Processual Civil cit., vol. I, p. 438.
} 
Em data recente, a Corte Especial do STJ propalou decisão valiosa a respeito, cuja ementa merece ser transcrita: "A liquidação e a execução individual de sentença genérica proferida em ação civil coletiva pode ser ajuizada no foro do domicílio do beneficiário, porquanto os efeitos e a eficácia da sentença não estão circunscritos a lindes geográficos, mas aos limites objetivos e subjetivos do que foi decidido, levando-se em conta, para tanto, sempre a extensão do dano e a qualidade dos interesses metaindividuais postos em juízo (arts. 468, 472 e 474, CPC e 93 e 103, CDC)" (REsp 1243887/PR, Rel. Ministro Luis Felipe Salomão, j. 19/10/2011).

A reflexão vinha sendo assim encaminhada pela jurisprudência ${ }^{412}$, embora com hesitações. E na doutrina a tese é encampada pela maioria ${ }^{413}$, que aponta a inoperância dos arts. $2^{\circ}$ e $2^{\circ}$-A da Lei 9.494/97. No que diz respeito aos direitos indivisíveis, a explicação é simples: o corte territorial da coisa julgada é inviável.

A propósito dos direitos homogêneos, que pela sua divisibilidade poderiam até aceitar a limitação, o sistema cuida de desmenti-la. Uma vez que o critério para a fixação da competência no CDC é concentrador, como aqui preconizado (infra, capítulo 2.1), é disfuncional admitir o trâmite conjunto de ações coletivas com objetos sobrepostos no plano coletivo.

\footnotetext{
${ }^{412}$ STJ, REsp 411.529/SP, Rel. Min. Nancy Andrighi, $3^{\text {a }}$ T., j. 24/06/2008.

${ }^{413}$ Nessa linha: Grinover, Código Brasileiro de Defesa do Consumidor comentado cit., pp. 189/193, e A ação civil pública refém do autoritarismo cit., pp. 238 e seguintes; Mancuso, Ação civil pública cit., pp. 342/343; Aluisio Mendes, Ações coletivas cit., p. 280; Cássio Scarpinella Bueno, O poder público em juízo cit., pp. 112/113; Nelson Nery e Rosa Maria Nery, Código de Processo Civil comentado e legislação extravagante cit., nota 12 ao art. 16 da Lei 7.347/85; Mazzilli, A defesa dos interesses difusos em juízo cit., $20^{\mathrm{a}}$ ed., pp. 264/266; Athos Gusmão Carneiro, Da competência no projeto de lei de nova ação civil pública, in Em defesa de um novo sistema cit., p. 81; Luiz Paulo da Silva Araújo Filho, Ações coletivas cit., p. 161 e seguintes.
} 


\section{Relação dos processos coletivos entre si e com as pretensões individuais e suspensão dos processos individuais}

O tema deste capítulo é muito íntimo do objeto do capítulo anterior e ambos são dependem da corrente compreensão acerca do objeto do processo coletivo.

Enquanto o regime da coisa julgada visa sanar os problemas decorrentes da repetição de uma demanda já julgada, as regras que tratam da conexão e da litispendência são destinadas a corrigir os inconvenientes da concomitância de ações. Em ambos os casos, a análise dos elementos objetivos da demanda é imprescindível para dimensionar o real alcance da tutela perseguida e obtida em cada um dos processos sob confronto e a melhor proteção do interesse coletivo envolvido.

Esse intento, a propósito, não escapa dos enunciados já contidos nos arts. $474^{414}$ e 475-N, inciso III $^{415}$, do Código de Processo Civil, que, no entender da doutrina, revelam a opção do sistema pela chamada jurisdição integral (ou resolução integral da lide $)^{416}$.

Nesse contexto, alinha-se com as finalidades do processo coletivo a moderna tendência doutrinária ${ }^{417}$ e legislativa ${ }^{418}$ a flexibilizar os dogmas da procedimento rígido, da interpretação restritiva dos pedidos, da estabilização da demanda ou, ainda, da estrita correlação entre a sentença e o pleito inicial.

\footnotetext{
414 “Art. 474. Passada em julgado a sentença de mérito, reputar-se-ão deduzidas e repelidas todas as alegações e defesas, que a parte poderia opor assim ao acolhimento como à rejeição do pedido".

415 "Art. 475-N. São títulos executivos judiciais: (...) III - a sentença homologatória de conciliação ou de transação, ainda que inclua matéria não posta em juízo".

${ }^{416}$ Sobre jurisdição integral, em linhas recentes: Mancuso, Jurisdição coletiva e coisa julgada cit., pp. 493/494.

${ }^{417}$ São referências recentes sobre as razões pelas quais essas regras rígidas não se adaptam ao modelo de "litigância social" e precisam ser revistas com diálogo entre as partes e a atividade gerencial do juiz sobre o processo coletivo, por todos: Daniela Monteiro Gabbay, cit., p. 80/82 e 95 e seguintes, e Swarai Cervone de Oliveira, cit., pp. 74/78.

${ }^{418}$ Cf. Código Modelo de Processos Coletivos para Ibero-América: "Art. 10. Pedido e causa de pedir - Nas ações coletivas, o pedido e a causa de pedir serão interpretados extensivamente. Par. $1^{\circ}$. Ouvidas as partes, o juiz permitirá a emenda da inicial para alterar ou ampliar o objeto da demanda ou a causa de pedir. Par. $2^{\circ}$. O juiz permitirá a alteração do objeto do processo a qualquer tempo e em qualquer grau de jurisdição, desde que seja realizada de boa-fé, não represente prejuízo injustificado para a parte contrária e o contraditório seja preservado", e Anteprojeto de Código Brasileiro de Processos Coletivos: "Art. $5^{\circ}$ Pedido e causa de pedir nas ações coletivas, a causa de pedir e o pedido serão interpretados extensivamente, em conformidade com o bem jurídico a ser protegido. Parágrafo único. A requerimento da parte interessada, até a prolação da sentença, o juiz permitirá a alteração do pedido ou da causa de pedir, desde que seja realizada de boa-fé, não represente prejuízo injustificado para a parte, e o contraditório seja preservado, mediante possibilidade de nova manifestação de quem figure no pólo passivo da demanda, no prazo de 10 (dez) dias, com possibilidade de prova complementar, observado o $\S 3^{\circ}$ do art. $10^{\prime \prime}$.
} 
Então, embora os tradicionais elementos identificadores da demanda (partes, pedido e causa de pedir) ainda sirvam para o estudo da relação entre os processos coletivos entre si e com os processos individuais, devemos partir dessa nova visão sobre o objeto processual $^{419}$. E mais, também os elementos subjetivos da demanda são repensados quando o conflito é molecularizado.

Para os parâmetros que regem os conflitos de índole individual, o relacionamento entre os processos produzem: litispendência (quando os três elementos da demanda são idênticos - art. 301, $\S 2^{\circ}$, do CPC), continência (gênero de litispendência, com identidade parcial dos pedidos, sendo um mais amplo do que o outro - art. 104 do CPC) ou conexão (se há identidade entre a causa de pedir, próxima ou remota, ou o pedido - art. 103 do CPC).

Em um sistema processual coletivo, o convívio entre ações coletivas é tratado de uma modo peculiar.

Primeiro, para a identificação das partes envolvidas nas demandas, não basta ter em vista o sujeito presente em juízo, pois a parte na relação jurídica material, verdadeira titular do direito debatido, em regra, não intervém no processo por lhe faltar legitimidade coletiva ${ }^{420}$. Assim, se em uma primeira ação o direito que pertence a uma dada coletividade vem sendo adequadamente representado pelo substituto, não há razão para o sistema permitir que um outro substituto veicule uma segunda ação almejando a proteção do mesmo direito.

Segundo, como já se afirmou, a causa de pedir e o pedido de uma ação coletiva não sofrem os mesmos rigores de um processo individual. Então, ainda que sob fundamentos próprios (diferentes causas de pedir), ou com a pretensão de defender o interesse coletivo por caminhos diversos (diferentes pedidos), pode haver litispendência entre duas demandas coletivas quando se busca solucionar o mesmo conflito de interesses no plano material ${ }^{421}$.

\footnotetext{
${ }^{419}$ Vide por todos: Grinover, A ação civil pública no STJ cit., p. 32/33.

${ }^{420}$ Nesse sentido, Luiz Guilherme Marinoni e Sérgio Cruz Arenhart alertam que: “os legitimados para essas ações não agem em defesa de direito próprio, mas sim alheio (legitimação extraordinária), pertencente à coletividade ou a certo grupo de pessoas. O sujeito material do processo, portanto, permanece sendo o mesmo, ainda que distintos os legitimados "formais' para a ação" (cf. Curso de processo civil cit., pp. $344 / 345)$.

${ }^{421}$ Ilustrando a litispendência pela superposição entre alguns dos elementos das ações, Mancuso recorre ao exemplo da concomitância entre uma ação civil pública, que almeja o fechamento de uma indústria poluidora, e uma ação coletiva, em nome dos interesses individuais homogêneos dos trabalhadores da
} 
Fruto da convivência entre ações coletivas pelas quais, de uma forma ou de outra, pretende-se tutelar o mesmo interesse supraindividual, a litispendência nesse âmbito se assemelha com a conexão. Exemplos de tendência que suprime a rigidez do conceito tradicional de conexão são os art. 29 do Código Modelo de Processos Coletivos para a Ibero-América ${ }^{422}$ e art. $5^{\circ}, \S 1^{\circ}$, do Projeto de Lei da Ação Civil Pública ${ }^{423}$.

No campo do processo individual, também era notável a aproximação do conceito de conexão mais com a relação substancial (do conflito da vida) trazida ao processo e menos com a forma de apresentação do conflito em juízo, na forma do art. 40 do Anteprojeto do novo Código de Processo Civil ${ }^{424}$. Na tramitação do Projeto 8.046/2010 no Senado, a proposta infelizmente cedeu ao apego com o conceito obtuso já previsto no atual Código (conforme redação do art. 55, caput do projeto).

Mas no campo dos processos coletivos, o conceito elástico de litispendência se harmoniza com a forma molecularizada de apresentação do conflito, evitando a multiplicidade de ações sobre o mesmo aspecto da relação material, e o compromisso mais sério com a resolução integral do litígio, já que desinteressa "deixar resíduos conflitivos marginais que no futuro propiciarão novas controvérsias, num perverso e infindável círculo vicioso que desserve a sociedade e desacredita a função jurisdicional”425.

Por isso, em se tratando de ação coletiva, a litispendência não deve conduzir necessariamente à extinção do segundo processo, como estabelece o art. 267, V, do atual Código de Processo Civil. De se considerar de lege lata a permissão de que sejam reunidas as causas, conforme disciplina o art. 105 do CPC (com fulcro na conexão), alternativa que tem a vantagem de não tolher as iniciativas de cada um dos legitimados ${ }^{426}$.

indústria, com pedido de ressarcimento pelos danos causados a sua saúde (Jurisdição coletiva e coisa julgada cit., p. 495).

422 "Art. 29. Conexão - Se houver conexão entre as causas coletivas, ficará prevento o juízo que conheceu da primeira ação, podendo ao juiz, de ofício ou a requerimento da parte, determinar a reunião de todos os processos, mesmo que nestes não atuem integralmente os mesmos sujeitos processuais".

423 "Na análise da identidade da causa de pedir e do objeto, será preponderantemente considerado o bem jurídico a ser protegido".

424 “Consideram-se conexas duas ou mais ações, quando, decididas separadamente, gerarem risco de decisões contraditórias".

${ }^{425}$ Cf. Transposição das águas do Rio São Francisco: uma abordagem jurídica da controvérsia, disponível em Revista dos Tribunais on line, acesso em 30/08/2011.

${ }^{426}$ Mancuso, Jurisdição coletiva e coisa julgada cit., p. 497. No mesmo sentido: Teresa Arruda Alvim Wambier, Litispendência em ações coletivas, in Tutela coletiva: 20 anos da Lei da Ação Civil Pública e do Fundo de Defesa de Direitos Difusos - 15 anos do Código de Defesa do Consumidor (coord. Paulo Henrique dos Santos Lucon), São Paulo, Atlas, 2006, p. 277. 
Nesse mister, requisito indispensável para a reunião de causas é que as ações coletivas se encontrem na mesma fase procedimental e que o julgamento conjunto convenha para a resolução integral do conflito ${ }^{427}$. Caso contrário, a medida será atécnica e atuará em desfavor da efetividade do processo. Assim nos posicionamos ao lado do entendimento cristalizado na Súmula 235 do $\mathrm{STJ}^{428}$, aplicável indistintamente a todo tipo de processo $^{429}$.

Nas situações em que, ao contrário a reunião não for recomendável, também acreditamos que a extinção do segundo processo é medida extrema a se evitar. Se a conexão for tão intensa que o prosseguimento de uma ação possa levar a julgamento incoerente ou até incompatível com o decidido em outra ajuizada anteriormente e já em fase de recurso, deve ser facultado ao juiz suspender o curso do segundo processo, com fulcro no art. 265, IV,$a^{430}$, do CPC (prejudicialidade externa), para se aguardar o resultado de mérito do primeiro.

Convém exemplificar. Uma primeira ação coletiva é manejada pelo Ministério Público, em face de administradoras de cartão de crédito, requerendo a declaração da nulidade do seguro contra perda e roubo quando ausente inequívoco consentimento do consumidor pela contratação do serviço. Após, determinada associação de defesa do consumidor ajuíza ação coletiva pretendendo, com fundamento na abusividade da prática descrita no art. 39, III, do CDC, a condenação genérica de instituição financeira a restituir os valores descontados sem autorização dos titulares de cartões de crédito, a título de seguro por perda e roubo.

Não sendo possível a reunião das causas, é lícito ao juiz da segunda ação suspender o processo para aguardar o pronunciamento judicial a respeito da nulidade de tal contrato de seguro, antes de fundamentar a condenação genérica na nulidade daquela mesma prática.

\footnotetext{
${ }^{427}$ Preocupação semelhante está expressa no art. $5^{\circ}, \S 2^{\circ}$, do Projeto de Lei de Ação Civil Pública: "Na hipótese de litispendência, conexão ou continência entre ações coletivas que digam respeito ao mesmo bem jurídico, a reunião dos processos poderá ocorrer até o julgamento em primeiro grau".

428 "Súmula 235. A conexão não determina a reunião dos processos, se um deles já foi julgado". Na doutrina, de acordo com essa postura: Mazzilli, A defesa dos interesses difusos em juízo cit., $20^{\mathrm{a}}$ ed., p. 248; Mancuso, op. loc. cit.; Leonel, op. cit., p. 268.

${ }^{429}$ RMS 24.196/ES, Rel. Min. Felix Fischer, $5^{\text {a }}$ Turma, j. 13/12/2007.

430 “Art. 265. Suspende-se o processo: (..) IV - quando a sentença de mérito: a) depender do julgamento de outra causa, ou da declaração da existência ou inexistência da relação jurídica, que constitua o objeto principal de outro processo pendente".
} 
Situação diferente ocorreria se o pedido formulado pela associação de defesa dos consumidores consistisse na declaração da nulidade da cláusula excludente de responsabilidade da instituição financeira com relação aos consumidores lesados e que não tenham aderido ao contrato de seguro por perda e roubo de cartão de crédito. O baixo grau de conexão com a primeira ação movida pelo Ministério Público não impõe a suspensão do processo, sob pena de retardar injustificadamente o desfecho da segunda ação coletiva.

Prevalecerá, a teor do art. $2^{\circ}$ da Lei 7.347/85, a competência do juízo para o qual a primeira ação foi distribuída ${ }^{431}$. Assim, como já se afirmou, muito embora sejam de natureza absoluta as regras de competência para as ações coletivas, o deslocamento da causa conexa é possível para o juízo da primeira ação despachada.

A tudo isso poderia se contrapor o caráter divisível dos direitos individuais homogêneos, que suporta a coexistência de duas ou mais ações coletivas. É certo que o sistema processual repudia a existência de decisões incompatíveis na ordem prática e, por isso, no que diz respeito a direitos difusos e coletivos (indivisíveis por natureza), o provimento judicial não pode se decompor nem conviver com outro que com ele seja inconciliável.

Por outro lado, não se pode ignorar que a incompatibilidade lógica entre julgados, embora hoje tolerada pela ordem jurídica, não é desejável porque desprestigia o Poder Judiciário frente ao cidadão médio e se torna fator de insegurança jurídica.

Sob esse ângulo, é incorreto tratar o processo coletivo em defesa dos direitos individuais homogêneos como instrumento unicamente voltado a minimizar a crise do Judiciário com a multiplicação de processos idênticos; antes de facilitar a prestação do serviço jurisdicional, a jurisdição coletiva atende ao ditame constitucional da isonomia, porque não só amplia o acesso da coletividade à justiça como também uniformiza a resposta dada pelo Estado-juiz sobre os litígios de massa.

Não é de hoje que reformas pontuais no processo vêm priorizando a uniformização das decisões judiciais para litígios idênticos, com o fim de repelir o infeliz caráter lotérico que ainda recai sobre o Judiciário brasileiro. Nesse contexto podemos citar o incidente de uniformização de jurisdição, as súmulas impeditivas de recurso, a técnica de julgamento de recursos repetitivos, a possibilidade de improcedência liminar de causas

${ }^{431}$ Nesse contexto, a regra geral do art. 106 do CPC cede frente à norma especial consubstanciada na Lei n. $7.347 / 85$. 
idênticas quando envolverem questão de direito já julgada pelo mesmo juízo, tudo a denunciar que não estamos diante de mera tendência.

Mais do que isso, o julgamento uniforme de processos idênticos atende aos escopos social e jurídico da jurisdição. De um lado, os jurisdicionados se conformam quando, bem ou mal, o seu processo teve o mesmo desfecho de outros idênticos. De outro, a solução uniforme de conflitos envolvendo interesses individuais homogêneos - que admitem fruição ou lesão fracionada - reforça a imperatividade da norma abstrata objeto de pronunciamento judicial ${ }^{432}$.

Assim, são sempre mais aconselháveis as providências que preservam o ideal de resolução uniforme dos processos envolvendo direitos individuais homogêneos, não obstante eles sejam divisíveis.

Para ser possível realizar essa meta, não bastam somente as regras que permitam a reunião de causas ou a suspensão de processos conexos. É vital catalogar as ações coletivas em curso em todo o território nacional, viabilizando a todo juiz brasileiro a consulta e o reconhecimento de causas conexas.

A criação de um banco de dados nacional está sendo encaminhada pelo Conselho Nacional de Justiça (Resolução Conjunta com o Conselho Nacional do Ministério Público n ${ }^{\circ}$ 2, de 21 de junho de 2011), tendo sido nomeado um Comitê Gestor do Cadastro Nacional de informações referentes a ações coletivas, pela Portaria $\mathrm{n}^{\circ} 88$, de 30 de agosto de 2011, que é grande passo em favor do bom aproveitamento dos mecanismos coletivos de resolução de conflitos.

De seu turno, no liame entre uma ação coletiva e outra ação individual, abordando direito surgido de questão comum, a lei estatui, no art. $104^{433}$ do Código de Defesa do Consumidor, que não há litispendência.

\footnotetext{
${ }^{432}$ Nesse sentido, é importante o alerta de Luiz Guilherme Marinoni e Sérgio Cruz Arenhart: “(...) o prejuízo considerado globalmente pode ser relevante, surgindo então o interesse na propositura da ação coletiva. Esta ação é de grande importância, bastando perceber que a norma (e assim o ordenamento jurídico, ao menos em parte) que impede que determinado produto seja oferecido ao público consumidor em quantidade inferior àquele determinado nos seu rótulo, poderia ficar sem atuação" (cf. Curso de processo civil cit., vol. 5, p. 310).

433 “Art. 104. As ações coletivas, previstas nos incisos I e II e do parágrafo único do art. 81, não induzem litispendência para as ações individuais, mas os efeitos da coisa julgada erga omnes ou ultra partes a que aludem os incisos II e III do artigo anterior não beneficiarão os autores das ações individuais, se não for requerida sua suspensão no prazo de trinta dias, a contar da ciência nos autos do ajuizamento da ação coletiva".
} 
Exceção a essa regra pode ser extraída do $\S 2^{\circ}$ do art. 103, segundo o qual o titular do direito homogêneo não pode intentar ação individual, para postular ressarcimento de dano, caso tenha intervindo em anterior ação coletiva julgada improcedente. Assim, se o réu poderá opor exceção de coisa julgada quando demandado em ação individual movida por aquele que se vinculou voluntariamente ao processo coletivo, isso significa que, na pendência da ação coletiva, deve ser obstada qualquer iniciativa do legitimado individual que tenha figurado como litisconsorte do autor coletivo.

O legislador acertou ao afastar a litispendência nas hipóteses em que uma ação individual é confrontada com outra coletiva deduzindo pedido a respeito de direitos difusos ou coletivos. Como acentua a doutrina ${ }^{434}$, a lei cumpre papel didático pois, a rigor, a relação entre o processo essencialmente coletivo e o individual está longe de configurar litispendência, pela falta de identidade entre todos os elementos da ação.

Mas a lei não tratou do cotejo entre a chamada ação acidentalmente coletiva e as ações respeitantes aos titulares individuais do direito.

E entre a ação coletiva e a ação individual há um nexo ou uma margem ainda que mínima - de sobreposição, já que o pedido de condenação genérica formulado pelo autor coletivo nada mais é do que a soma de pedidos individuais. Segundo nos informa Ada Pellegrini Grinover ${ }^{435}$, nesses casos, o fenômeno da litispendência se apresenta parcialmente e consiste na continência, tanto do objeto litigioso quanto dos titulares da relação jurídica material.

Todavia, tamanho grau de proximidade entre as demandas não recomenda nessa hipótese que necessariamente sejam tomadas as providências regulares a fim de sanar a litispendência ou a continência.

O sistema processual coletivo não foi concebido para anular a iniciativa judicial dos cidadãos - e nem teria autorização constitucional para tanto. Portanto, tanto a extinção quanto a suspensão automática e irrevogável do processo individual são medidas que, hoje, devem ser descartadas.

\footnotetext{
${ }^{434}$ Assim: Gidi, Coisa julgada e litispendência cit., p. 188/189; Mancuso, Defesa do Consumidor: reflexões acerca da eventual concomitância de ações coletivas e individuais, disponível em Revista dos Tribunais on line, acesso em 30/08/2011).

${ }^{435}$ Grinover, Significado social, político e jurídico da tutela dos interesses difusos cit., p. 13. Também nesse sentido: Yarshell, Observações a propósito da liquidação cit., p. 160.
} 
Até concordamos que a concomitância entre a ação individual e a ação coletiva em defesa de interesses individuais homogêneos está longe de ser o cenário ideal sob o ponto de vista da gestão da justiça (pois incentiva a litigiosidade de massa), mas é coerente com os escopos de facilitação do acesso e de fortalecimento da posição do consumidor em juízo e, também, se acomoda com o princípio da demanda ${ }^{436}$.

Não há ineditismo em observar que a presença de um extenso rol de direitos fundamentais na Constituição é sinal do garantismo erigido no período imediatamente seguinte aos regimes políticos autoritários. No plano infraconstitucional, os arts. $103, \S 2^{\circ}$, 104 do CDC são sinais claros de que a liberdade do indivíduo ainda é poupada frente às ações coletivas $^{437}$.

Essa é a mentalidade que conduziu os autores do anteprojeto do Código do Consumidor e, por isso, ela não pode ser menosprezada. Como asseverou Kazuo Watanabe, "essa preocupação pelas demandas coletivas de forma alguma significa desprezo pelas ações individuais. Teve o legislador a nítida noção da elevada importância da solução dos conflitos individuais, que no dia a dia das relações de consumo constituirão, certamente, a maioria, tanto que deixou sublinhada, no art. $5^{\circ}, \mathrm{n}^{\mathrm{o}} \mathrm{IV}$, do Código, a relevância da criação de Juizados Especiais de Pequenas Causas (hoje, Juizados Especiais de Causas Cíveis de Menor Complexidade) ${ }^{\natural 438}$.

Por isso discordamos em boa parte das consideradas tecidas pelo Ministro do STJ Sidnei Beneti em paradigmático julgamento de recurso repetitivo em torno da questão dos expurgos inflacionários devidos sobre cadernetas de poupança no período dos Planos Econômicos (RESP 1.110.549/RS, 2a Seção, j. 28/10/2009).

\footnotetext{
${ }^{436}$ De acordo com as lições de Carlos Alberto de Salles, "a suspensão automática das ações individuais, que favorece a economia processual e a maior eficácia do processo coletivo", "não pode ocorrer à custa do direito que todos os indivíduos têm de escolher pelo seguimento da demanda individual" (cf. Anteprojeto de nova lei da ação civil pública cit., p. 25). Segundo Mancuso, além de ter o "cuidado de assegurar uma "convivência pacífica' entre as tutelas coletiva e individual do consumidor (que passa por um refinado sistema de complementaridade entre aquelas vias), quis ainda o legislador cuidar para que aquelas duas alternativas não entrassem em 'rota de colisão', no caso de serem tomadas concomitantemente" (cf. Defesa do Consumidor: reflexões acerca da eventual concomitância cit., p. 2).

${ }^{437} \mathrm{O}$ direito projetado também tem suporte nessa premissa, conforme art. $7^{\circ}, \S 2^{\circ}$ do anteprojeto de Código Brasileiro de Processos Coletivos (que teve infelizes alterações durante a tramitação legislativa no sentido de impor a suspensão dos processos individuais): "A suspensão do processo individual perdurará até o trânsito em julgado da sentença coletiva, facultado ao autor requerer a retomada do curso do processo individual, a qualquer tempo, independentemente da anuência do réu, hipótese em que não poderá mais beneficiar-se da sentença coletiva".

${ }^{438}$ Cf. Código de Defesa do Consumidor cit., $10^{\mathrm{a}}$ ed., pp. 4/5. No mesmo sentido, Rodolfo de Camargo Mancuso afirma que não se pode "perder de vista o fato de que o lesado individual pode não querer aderir ao pleito coletivo, nem tampouco aguardar o seu desfecho, e nesse caso ele é livre para ajuizar sua própria demanda" (cf. Jurisdição coletiva e coisa julgada cit., p. 513).
} 
Na ocasião, a Segunda Seção daquela Corte constrangeu a livre escolha do indivíduo pois, em sede de ação coletiva, suspendeu ações individuais, desprezando a oposição dos interessados. Ou seja, transformou-se em obrigatória a suspensão que, na forma do art. 104 do CDC, é facultada ao indivíduo ${ }^{439}$.

Outro argumento daquele acórdão é o seguinte: "seria, convenha-se, longo e custoso caminho desnecessário, de cujo inútil trilhar os órgãos judiciários e as próprias partes conscientes concordarão em poupar-se, inclusive, repita-se, em atenção ao interesse público de preservar a viabilidade do próprio sistema judiciário ante as demandas multitudinárias decorrentes de macro-lides”. Coerente com a linha seguida neste estudo é a premissa de que a opção pela ação individual é um direito potestativo, não merecendo ser tachado de inútil assim abstratamente. De fato, pode ser uma opção custosa, mas uma vez que ela tenha sido feita, só cabe ao Judiciário prestar o serviço que, por livre escolha do seu consumidor, espera-se seja individualizado ${ }^{440}$.

Também não é possível impor a incidência do art. 543-C do CPC - o qual disciplina o julgamento de recursos repetitivos no STJ e no STF- antes da interposição de recurso dirigido aos tribunais superiores, quando sequer se inaugurou a competência recursal $^{441}$.

De vital importância, portanto, é que a suspensão da pretensão individual para aguardar julgamento de ação coletiva seja facultada e não imposta ao consumidor. E a fim de que essa faculdade não se esvazie, esforços merecem ser dedicados a uma eficiente comunicação dos autores individuais a respeito do trâmite da ação coletiva, a partir da qual se inicia o prazo de 30 dias previsto no art. 104.

\footnotetext{
${ }^{439}$ Aderindo a essa posição, vide Didier, Comentários ao Código Modelo de Processos Coletivos cit., pp. 388/389. No sentido de que o mecanismo assim criado destoa da regra do art. 104 do CDC: Grinover, Código Brasileiro de Defesa do Consumidor comentado cit., $10^{\mathrm{a}}$ ed., p. 217.

${ }^{440}$ Vale a referência às palavras de Teori Albino Zavascki que endossam esse posicionamento: "o julgamento das ações individuais supõe, necessariamente, cognição a respeito da situação particular de cada um dos seus autores, o que traz os inconvenientes próprios dos litisconsórcios ativos plurais, antes referidos, contra os quais o legislador estabeleceu barreiras de contenção (CPC, art. 46, parágrafo único) e que a técnica da ação coletiva visa evitar. Apesar da conexão, as ações individuais devem, portanto, ser processadas em seu juízo próprio, independentemente da ação coletiva, sob pena de se retirar dessa ação uma parte significativa das suas virtualidades e da sua essencial razão de ser" (cf. Processo coletivo cit., p. 177). De forma semelhante, Gidi pondera: "por se tratar de ato unilateral do autor, o requerimento de suspensão poderá ser revogado a qualquer tempo ou grau de jurisdição e sem qualquer restrição ou possibilidade de oposição por parte do réu" (cf. Coisa julgada e litispendência cit., p. 205).

${ }^{441}$ Neste ponto, o TJSP acertou ao decidir que "a suspensão dos processos envolvendo planos econômicos determinada no Recurso Extraordinário n ${ }^{\circ} 626.307$ (Ministro Dias Toffoli), não obsta o andamento das ações que nem mesmo chegaram à fase instrutória, tal e qual a hipótese dos autos" (AI $\mathrm{n}^{\circ}$ 013671047.2011.8.26.0000, $11^{\mathrm{a}}$ Câmara de Direito Privado, j. 4/08/2011). Na mesma linha é o entendimento da $1^{\mathrm{a}}$ Seção do STJ, conforme CC 47731/DF, rel. p/ acórdão Teori Albino Zavascki, j. 14/9/2005).
} 
O empenho nessa comunicação deve estar a cargo tanto dos órgãos que integral o Sistema Nacional de Defesa do Consumidor, como estipula o art. 94 do Código, quanto do réu, com especial interesse no julgamento concentrado da controvérsia multiplicada, e que tem o dever legal de prestar informação adequada ao consumidor ${ }^{442}$ de acordo com o art. $6^{\circ}$, inciso III, do Código.

Para finalizar o estudo do nexo entre as ações individuais e a ação coletiva, importa dizer que a reunião das causas pode, não raras vezes, ir de encontro com as garantias conquistadas pelo consumidor consistentes no foro privilegiado de seu domicílio (art. 101 do CDC) e na facilitação de sua defesa (art. $6^{\circ}$, VIII), o que seria um retrocesso ${ }^{443}$.

Assim, no relacionamento entre o processo coletivo e o individual sobre direitos homogêneos, só podemos consentir com propostas em sintonia com a facilitação e a promoção do acesso à justiça pelo consumidor e a liberdade de escolha que lhe é conferida pelo art. 104 do CDC, e não com medidas voltada apenas ao ““enxugamento’ da multidão de processos em poucos autos" (cf. RESP 1.110.549/RS).

\footnotetext{
${ }^{442}$ Esse dever é ampliado pelo projeto de Código Brasileiro de Processos Coletivos, na forma do art. $37, \S 2^{\circ}$ : "Cabe ao réu, na ação individual, informar o juízo sobre a existência de demanda coletiva que verse sobre idêntico bem jurídico, sob pena de, não o fazendo, o autor individual beneficiar-se da coisa julgada coletiva mesmo no caso de o pedido da ação individual ser improcedente, desde que a improcedência esteja fundada em lei ou ato normativo declarados inconstitucionais pelo Supremo Tribunal Federal".

${ }^{443}$ É famoso o texto de Humberto Theodoro Junior, intitulado Ações individuais e coletivas sobre relações de consumo - reunião de processos por conexão (Revista Síntese de Direito Civil e Processual Civil, $\mathrm{n}^{\circ}$ 37, 2005, pp. 28/34), no qual o autor milita em favor de uma reunião obrigatória de ações individuais para julgamento conjunto. De fato, a reunião de ações individuais entre si é possível, se não resultar em litisconsórcio multitudinário e desde que tal medida não recue na garantia do consumidor do foro privilegiado.
} 


\section{Sentença genérica e procedimento para liquidação e execução da sentença coletiva}

\subsection{Sentença genérica}

Decorre do art. $83^{444}$ do Código do Consumidor que, em prol da efetividade das ações coletivas, é autorizado ao autor coletivo requerer todo provimento capaz de tutelar adequadamente a coletividade por ele representada. Afinal, também nas relações de massa deve ser verdadeiro o famoso adágio chiovendiano, datado de 1911, de que "il processo deve dare per quanto è possibile praticamente a chi ha un diritto tutto quello e proprio quello ch'egli ha diritto di conseguire".

Dessa íntima relação entre os institutos processuais e a crise de direito material deduzida em juízo decorre que as ordens judiciais tendem a ser próximas da tutela específica do direito objetivo. Como acentua o Professor Flávio Yarshell, o próprio conceito de tutela específica "é praticamente coincidente com a idéia da utilidade das decisões, dado que naquela primeira a atividade jurisdicional tende a proporcionar ao credor o exato resultado prático atingível pelo adimplemento"445.

Sinal de que particularmente nos conflitos de índole coletiva também se privilegia a tutela específica à comunidade atingida pelo ato ilícito está presente já no art. 11 da Lei 7.347/1985, que faculta ao juiz determinar "o cumprimento da prestação da atividade devida ou a cessação da atividade nociva, sob pena de execução específica, ou de cominação de multa diária, se esta for suficiente ou compatível, independentemente de requerimento do autor", ao lado da figura do mandado de segurança coletivo prevista no art. $5^{\circ}$, inciso LXX, da Constituição em vigor.

A bem da verdade a autorização para que seja postulada em juízo toda e qualquer medida lícita e adequada à solução de uma crise jurídica é inerente à prerrogativa abstrata do direito de ação ${ }^{446}$. Assim, complementado pelo art. 84, o art. 83 do Código do Consumidor veio a lume para explicitar que as ações coletivas também são marcadas pelo caráter da atipicidade e são instrumento de realização prática e específica do direito material violado.

\footnotetext{
444 “Art. 83. Para a defesa dos direitos e interesses protegidos por este Código são admissíveis todas as espécies de ações capazes de propiciar sua adequada e efetiva tutela".

${ }^{445}$ Cf. Yarshell, Tutela jurisdicional específica cit., p. 59.

${ }^{446}$ Yarshell, Tutela Jurisdicional cit., $2^{\mathrm{a}}$ ed., pp. 58/59 e 154.
} 
Também o Projeto de lei n. 5.139/2009, pelo seu art. $26^{447}$, preconiza forte estímulo aos provimentos mandamentais e à adoção de medidas que privilegiam a atuação da ordem estatal independentemente de execução para pagamento de quantia.

Residualmente, para a hipótese em que, esgotadas as possibilidades para a tutela específica, a lei permite que, via ação coletiva, também sejam reparados os danos individualmente sofridos pelas vítimas do ato ilícito, providência que antes dependia da respectiva ação ressarcitória individual. Inspirado na class action for damages da common law norte-americana, o legislador brasileiro consagrou a ação coletiva com pedido condenatório visando à reparação dos danos pessoalmente sofridos por uma coletividade, que veio a ser disciplinada pelos arts. 91 e seguintes do Código do Consumidor.

Mas aqui vale uma ressalva. Embora no capítulo II do Código do Consumidor, destinado às "Ações Coletivas para a Defesa de Interesses Individuais Homogêneos", as regras remetam à ideia de sentença genérica, não é verdade a afirmação de que os provimentos condenatórios (de obrigação de fazer ou não fazer, entregar coisa ou pagar) são os únicos postuláveis para proteção de direitos homogêneos ${ }^{448}$.

Na linha da lição do Professor Kazuo Watanabe ${ }^{449}$, entendemos que, se a suposta vedação de tutela constitutiva para, por exemplo, anular cláusula contratual abusiva presente em milhares de contratos de adesão, repousa no fato de que "nessa espécie de demanda não é cabível (...) repartição da atividade jurisdicional”"450, a verdade é que na fase de conhecimento não se está diante de direito divisível.

Desse modo, os titulares de interesses homogêneos serão também tutelados na fase de conhecimento, já que a sentença os beneficia, mas a fruição individual do direito - e respectiva divisibilidade da reparação dos danos pessoalmente sofridos - é reservada às fases de liquidação e execução. Então, não sendo obstada a iniciativa individual para a

\footnotetext{
${ }^{447}$ Art. 26. Na ação que tenha por objeto a condenação ao pagamento de quantia em dinheiro, deverá o juiz, sempre que possível, em se tratando de valores a serem individualmente pagos aos prejudicados ou de valores devidos coletivamente, impor a satisfação desta prestação de ofício e independentemente de execução, valendo-se da imposição de multa e de outras medidas indutivas, coercitivas e sub-rogatórias".

${ }^{448}$ É sempre lembrada a posição de Teori Albino Zavascki, segundo quem: "Em se tratando de ação desconstitutiva, cuja sentença atingirá imediatamente a relação jurídica individual, a iniciativa do consumidor (de requerer ou autorizar o ajuizamento) deve ser entendida como requisito indispensável à propositura da demanda. Não é cabível, portanto, ação coletiva em defesa de direitos individuais homogêneos que tenha por objeto a obtenção de tutela de natureza constitutiva ou desconstitutiva" (cf. Processo coletivo cit., p. 170).

${ }^{449}$ Cf. Código Brasileiro de Defesa do Consumidor cit., $10^{\mathrm{a}}$ ed., pp. 20/23. Nessa esteira, como afirma Vigliar, a verdade é que "os direitos coletivos em sentido estrito representam uma especial categoria de interesses individuais homogêneos", pois são "indivisíveis pela vontade do legislador" embora não se possa afirmar "que apenas a tutela coletiva seria viável" (cf. Interesses individuais homogêneos cit., p. 37).

${ }^{450}$ Cf. Zavascki, Processo coletivo cit., p. 169.
} 
pretensão constitutiva, ocorre que, a depender do bem jurídico tutelado (no exemplo: (abusividade de cláusula contratual de contrato de adesão), é correto afirmar que poderemos nos deparar com ações pseudoindividuais ${ }^{451}$, e não o contrário (ações pseudocoletivas $^{452}$ ).

Feito esse parêntese, voltemos a tratar da sentença genérica, que é o ato culminante da fase de conhecimento do processo coletivo que sirva para a responsabilização do réu pelos danos provocados à coletividade, na forma do art. 95 do CDC.

Mesmo genérica, a sentença assim produzida é condenatória porque não se resume a declarar a existência ou inexistência de uma relação jurídica, mas contém um segundo momento lógico de imposição da sanção executiva após o acertamento do valor da obrigação ${ }^{453}$. Na medida em que a sentença declara a exigibilidade de uma obrigação, sob pena de execução forçada, estamos diante de uma condenação. Nas clássicas palavras de Antônio Carlos Costa e Silva, "a sentença de condenação observa exatamente a função dúplice que a preponderante orientação doutrinária lhe empresta: função declaratória e função sancionadora, porque, em primeiro lugar, declara a existência do direito do autor a uma prestação a cargo do réu, e, seguidamente, faz vigorar, para o caso concreto, o poder de coercibilidade existente na Jurisdição" ${ }^{454}$.

\footnotetext{
${ }^{451}$ Essa conclusão é especialmente verdadeira, como destaca Kazuo Watanabe (op. loc. cit.), quando o direito dos consumidores se insere numa política de equilíbrio atuarial (v.g., a estrutura tarifária de telefonia), cujo equacionamento é obstado se resguardada a liberdade de adesão do titular de direito homogêneo. Neste diapasão, vide Ruy Zoch Rodrigues, Ações repetitivas - Casos de antecipação de tutela sem o requisito de urgência, São Paulo, Revista dos Tribunais, 2010, pp. 98/99.

${ }^{452}$ Nas palavras de Luiz Paulo da Silva Araújo, "Nas ações pseudocoletivas, em realidade, conquanto tenha sido proposta a ação por um único legitimado extraordinário, na verdade, estão sendo pleiteados, específica e concretamente, os direitos individuais de inúmeros substituídos, caracterizando-se uma pluralidade de pretensões que, em tudo e por tudo, é equiparável à do litisconsórcio multitudinário. (...) tratando-se de pedidos específicos, e visando à satisfação imediata e concreta dos interessados, verdadeiras pretensões individuais simplesmente aglutinadas, caberia ao ente legitimado nomear e qualificar todos os substituídos" (cf. Ações coletivas cit., pp. 200/201).

${ }^{453}$ Cf. Paulo Henrique dos Santos Lucon e Érica Barbosa e Silva, Análise crítica da liquidação e execução na tutela coletiva, in Tutela Coletiva (coord. Paulo Lucon), São Paulo, Atlas, 2006, pp. 165 e 167.

${ }^{454}$ Cf. Tratado do Processo de Execução, vol. 1, $2^{\mathrm{a}}$ ed., Rio de Janeiro, AIDE, 1986, p. 93. Também em defesa da tese de que a sentença genérica possui natureza condenatória, vide: Humberto Theodoro Junior, Processo de execução, 19a ed., LEUD, São Paulo, 1999, pp. 215/217; Luiz Rodrigues Wambier, Flávio Renato Correia de Almeida e Eduardo Talamini, Curso Avançado de Processo Civil, vol. 2, $4^{\mathrm{a}}$ ed., São Paulo, Revista dos Tribunais, 2001; Araken de Assis, Manual do Processo de Execução, $4^{\mathrm{a}}$ ed., São Paulo, Revista dos Tribunais, 1997, p. 87; Sérgio Shimura, Tutela coletiva e sua efetividade cit., p. 150; Grinover, Código Brasileiro de Defesa do Consumidor comentado cit., 10 a ed., p. 152; Marinoni e Arenhart, Curso de Processo Civil cit., p. 331. Em sentido contrário, vale a referência a: Luiz Paulo da Silva Araújo Filho, Ações coletivas cit., pp. 130/133, com fundamento nas lições de Calamandrei e Fazzalari; Zavascki, Processo coletivo cit., p. 157; e Cândido Rangel Dinamarco, para quem, "Essa sentença declara que houve lesão a direitos individuais homogêneos, mas, como toda sentença coletiva, não individualiza os sujeitos lesados. No tocante a cada um
} 
Embora atualmente a discussão possa ter perdido utilidade prática, com o advento do art. 475-N, inciso $\mathrm{I}^{455}$, do Código de Processo Civil, a referência ainda é saudável na medida em que a sentença declaratória que reconhece a exigibilidade de obrigação inadimplida nada mais é do que uma verdadeira sentença condenatória, porque depende, em regra, da atuação coercitiva, exigência da qual está livre, por sua própria natureza, a chamada sentença declaratória pura ${ }^{456}$.

Além disso, é lícito afirmar que a decisão que dá cabo à liquidação tem natureza declaratória, relegando, portanto, a função sancionadora à decisão derradeira da fase de conhecimento. Isso porque no momento processual em que se apura unicamente o quantum debeatur, já ficou para trás a imposição ao réu do dever de indenizar que, a par de eventual jogo de palavras, constitui a verdadeira condenação. Afinal, mesmo à míngua de liquidação e execução individual, o réu pode ser compelido (sanção) ao pagamento de indenização que será revertida ao Fundo em que são depositados recursos destinados à reconstituição dos bens lesados.

A sentença é ainda genérica porque impõe a obrigação de reparar o dano causado à coletividade, sob uma ótica impessoal, e por isso depende de uma fase posterior do procedimento que determine a sua liquidez, ou seja, que defina o dano individualmente sofrido e a extensão pecuniária da ordem de reparação.

Não é essencial que a definição do quantum debeatur seja retardada para a liquidação da sentença coletiva. Pode se dar que, já na fase de conhecimento, o juiz possua elementos para aferir um valor mínimo para a condenação dos consumidores prejudicados pelo ato ilícito do réu. Assim é que no Projeto de Lei 5.139/2009, há regra recomendando que, sempre que possível, o juiz predetermine o valor mínimo da indenização devida a cada titular individual ${ }^{457}$, providência essa que desde agora vem sendo admitida pela

destes, portanto, ela não contém mais do que a declaração de mera potencialidade lesiva" (cf. Execução Civil, $5^{\text {a }}$ ed., São Paulo, Malheiros, 1997, p. 551).

455 “Art. 475-N. São títulos executivos judiciais: I - a sentença proferida no processo civil que reconheça a existência de obrigação de fazer, não fazer, entregar coisa ou pagar quantia".

${ }^{456}$ Com precisão, Cândido Rangel Dinamarco salienta que a declaratória, com eficácia executiva, só pode ser admitida quando essa via for opção do interessado (cf. Instituições de Direito Processual Civil, vol. IV, São Paulo, Malheiros, 2009, pp. 247/248). Para Ada Pellegrini Grinover, a novidade trazida pela Lei 11.232/2005 também não desnatura a sentença declaratória tradicional, que prescinde de execução (Cf. Mudanças estruturais no processo civil brasileiro, in Revista de Direitos e Garantias Fundamentais, n. 1, 2006, p. 205).

457 “Art. 27. (...) $\$ 3^{\circ} \mathrm{Na}$ sentença condenatória à reparação pelos danos individualmente sofridos, sempre que possível, o juiz fixará o valor da indenização individual devida a cada membro do grupo ou um valor mínimo para a reparação do dano". 
jurisprudência desde que apurada a indenização a partir dos fatos que compõem a causa de $\operatorname{pedir}^{458}$.

Mesmo quando genérica, a condenação é certa, cumprindo requisito de toda sentença judicial, conforme estabelece o art. 460, parágrafo único ${ }^{459}$, do Código de Processo Civil, porque assegura a responsabilidade do réu pelos danos provocados por sua conduta ilícita, desde que o interessado demonstre a condição de individualmente lesado, e fixa os critérios para a individualização da indenização.

Essa fase na qual a obrigação reconhecida pela condenação genérica conquista liquidez (e quantifica os danos causados pessoalmente aos consumidores) é justamente a liquidação da sentença, pressuposto essencial para a posterior execução do julgado. Em se tratando de tutela ressarcitória, que se realiza mediante o pagamento do quantum debeatur, a apuração desse montante é meio para se alcançar a máxima efetividade na tutela dos interesses individuais homogêneos ${ }^{460}$.

\subsection{Procedimento para liquidação e execução}

O juízo competente para o processamento da liquidação e da execução da sentença genérica, em regra, é o mesmo juízo da fase de conhecimento da ação. No entanto, no microssistema dos processos coletivos, relevante distinção há de ser feita.

Conforme preceitua o art. 97 do CDC: “A liquidação e a execução de sentença poderão ser promovidas pela vítima e seus sucessores, assim como pelos legitimados de trata o art. 82", evidenciando que há duas modalidades de liquidação e execução de uma sentença genérica coletiva, aquela promovida individualmente pelos consumidores e outra de iniciativa dos legitimados extraordinários.

$\mathrm{Na}$ primeira hipótese, não se coadunaria com o espírito do Código do Consumidor exigência de que o consumidor fosse obrigado a buscar a satisfação de um crédito em foro muitos vezes distante de seu domicílio. Por isso, o projeto de Código do Consumidor continha a regra do parágrafo único do art. 97, prevendo que "A liquidação de

\footnotetext{
${ }^{458}$ Dentre os julgados mais recentes, frisamos: AgRg no REsp 1192557/MG, Rel. Min. Sidnei Beneti, $3^{\text {a }}$ Turma, j. 22/06/2010; REsp 1041745/ES, Rel. Min. Denise Arruda, $1^{\text {a }}$ Turma, j. 04/06/2009.

459 “Art. 460. É defeso ao juiz proferir sentença, a favor do autor, de natureza diversa da pedida, bem como condenar o réu em quantidade superior ou em objeto diverso do que lhe foi demandado. Parágrafo único. A sentença deve ser certa, ainda quando decida relação jurídica condicional".

${ }^{460}$ Shimura, Tutela coletiva e sua efetividade cit., p. 147 e Leonel, Manual do processo coletivo cit., p. 400.
} 
sentença, que será por artigos, poderá ser promovida no foro do domicílio do liquidante, cabendo-lhe provar, tão só, o nexo de causalidade, o dano e seu montante".

O dispositivo foi inadvertidamente vetado pela Presidência mas, como bem observou a Professora Ada Pellegrini Grinover, uma das responsáveis pelo anteprojeto, felizmente manteve-se íntegra a redação do parágrafo $2^{\circ}$ do art. $98^{461}$ do Código, que conserva o foro privilegiado do membro do grupo interessado na liquidação e execução da sentença coletiva.

A interpretação correta desse dispositivo leva a crer que não se está a tratar, no inciso II, da liquidação e execução individual da sentença condenatória individual, por dois motivos. O primeiro consiste no fato de que o caput do art. 98 se refere à execução coletiva fazendo remissão, portanto, à sentença genérica. Assim, se os dois parágrafos do art. 98, segundo a boa técnica legislativa ${ }^{462}$, só podem ser desdobramento do tema tratado no respectivo caput, constituem eles regramento para a liquidação e execução da mesma sentença genérica (e não da sentença individual que, aliás, sequer precisaria ser genérica, podendo ser liquidada durante a fase de conhecimento).

O segundo motivo é que, caso disciplinasse a liquidação e a execução individual, de sentença individual, o dispositivo seria inútil, porque repetiria o preceito geral do Código de Processo Civil de que a liquidação e o cumprimento da sentença prosseguem perante o mesmo juízo da fase de conhecimento (arts. 475-A, §2º 475-P, II).

Não bastasse tudo isso, em mais uma oportunidade o Código do Consumidor deixa expressa a garantia do foro privilegiado do consumidor: no art. 101 que, observando o princípio da facilitação da defesa inscrito no art. $6^{\circ}$, VIII, autoriza que a ação de responsabilidade civil do fornecedor de produtos e serviços, seja proposta no foro do domicílio do autor, desde que respeitada a eventual competência de justiça especializada ${ }^{463}$.

461 “Art. 98. A execução poderá ser coletiva, sendo promovida pelos legitimados de que trata o art. 82, abrangendo as vítimas cujas indenizações já tiveram sido fixadas em sentença de liquidação, sem prejuízo do ajuizamento de outras execuções. $\S 1^{\circ}$ A execução coletiva far-se-á com base em certidão das sentenças de liquidação, da qual deverá constar a ocorrência ou não do trânsito em julgado. §2。 É competente para a execução o juízo: I - da liquidação da sentença ou da ação condenatória, no caso de execução individual; II da ação condenatória, quando coletiva a execução".

${ }^{462}$ Lei Complementar n. 95/1998, que dispõe sobre a elaboração, a redação, a alteração e a consolidação das leis, conforme determina o parágrafo único do art. 59 da Constituição Federal.

${ }^{463}$ Yarshell, Observações a propósito da liquidação cit., p. 164. 
Assim, ao contrário da regra da concentração para o julgamento da ação coletiva, na lição de Luiz Paulo da Silva Araújo Filho ${ }^{464}$, prevalece a disseminação de liquidações e execuções individuais, como já antes preconizara, dentre outros, Araken de Assis $^{465}$, ao propor um abrandamento na fórmula do art. 575, II, do CPC.

Doutra parte, no que se refere ao objetivo da liquidação individual, é ineficaz o veto ao parágrafo único do art. 97 porque, reconhecido o dever de indenizar do réu da ação coletiva, restará para a fase de liquidação a prova do dano sofrido individualmente (ou da condição do indivíduo como lesado), do nexo de causalidade entre o dano e o ato praticado pelo réu, a fim de se chegar à sua dimensão pecuniária, como semelhantemente dispõe o art. $475-\mathrm{E}^{466}$ do CPC.

Nesse tema, é comum afirmação de que o fato novo indicado pelo art. 475-E do CPC (que já aparecia na redação do anterior art. 608) não é qualquer fato, porque vige a regra da fidelidade da liquidação ao título. Os limites da liquidação por artigos são bem explicitados por Humberto Theodoro Junior: "Não cabe a discussão indiscriminada de quaisquer fatos arrolados ao puro arbítrio da parte. Apenas serão arrolados e articulados os fatos que tenham influência na fixação do valor da condenação ou na individuação do seu objeto. E a nenhum pretexto será lícito reabrir a discussão em torno da lide, definitivamente decidida na sentença de condenação" 467 .

Contudo, em se tratando de liquidação de sentença coletiva genérica, esses limites são mais brandos, porque toda questão que diga respeito exclusivamente à relação entre o réu e o indivíduo pessoalmente considerado (que supera o núcleo de

\footnotetext{
${ }^{464}$ Cf. Ações coletivas cit., p. 190. Na mesma linha de pensamento: Yarshell, Observações a propósito da liquidação cit., p. 163.

${ }^{465}$ Para o autor: "A fórmula grotescamente ruim do art. 575, II, revela-se contrária a objetivos progressistas, que conduziram à fixação da competência da demanda condenatória. À vítima de ilícito absoluto, ocorrido em acidente de trânsito, interessa propor a ação condenatória no seu domicílio (art. 100, parágrafo único, do $\mathrm{CPC}$ ); se o fizer, iludida pelo benefício, terá ulteriores dificuldades na execução, porque os bens aptos à satisfação do crédito se situam, com boa dose de probabilidade, em foro diverso - domić́lio do executado" (Manual do processo de execução cit., p. 182). Demonstração de que sobressai nesse tema um critério de conveniência e comodidade, o legislador reformista de 2005 inseriu no parágrafo único do art. 475-P do Código de Processo Civil norma que evidencia a relatividade da competência do juízo da execução: "No caso do inciso II do caput deste artigo, o exeqüente poderá optar pelo juízo do local onde se encontram bens sujeitos à expropriação ou pelo do atual domicílio do executado, caso em que a remessa dos autos do processo será solicitado ao juízo de origem". Diversamente, Patrícia Miranda Pizzol sustenta que, sendo de caráter absoluto a competência prevista no art. 575, II, do CPC, há forte argumento contra a competência do juízo do domicílio do consumidor, quando diverso do juízo da ação coletiva de conhecimento (cf. Liquidação nas ações coletivas, São Paulo, Lejus, 1998, pp. 190/192). Também se apegando à regra do art. 575, II, do CPC (atual art. 475-P), Arruda Alvim, Código do Consumidor Comentado cit., p. 442.

466 "Art. 475-E. Far-se-á a liquidação por artigos, quando, para determinar o valor da condenação, houver necessidade de alegar e provar fato novo".

${ }^{467}$ Cf. Processo de execução cit., p. 224.
} 
homogeneidade), não tendo sido objeto da fase de conhecimento, poderá ser apreciada em liquidação ${ }^{468}$.

Por seu turno, em liquidação e execução iniciadas pelo legitimado extraordinário, em benefício de vítimas e sucessores identificados, o caráter coletivo remanesce apenas na figura do autor ${ }^{469}$ porque haverá individuação do quantum debeatur de acordo com o número dos interessados que se habilitarem, tal como se estivessem em litisconsórcio.

Nessa hipótese, o autor coletivo, a partir do instante em que atua com autorização de indivíduos determinados, não ocupa mais o papel de legitimado extraordinário, pois passa a cumprir função de representante processual, como elucida Ada Pellegrini Grinover ${ }^{470}$.

Há polêmica também em torno da legitimidade do Ministério Público para promover liquidação e execução de sentenças genéricas envolvendo direitos patrimoniais disponíveis. É certo que o Ministério Público não pode estar autorizado a defender interesses disponíveis de pessoas determinadas em sede de liquidação ou execução individual, quando o elemento coletivo da controvérsia, a rigor, já se esgotou ${ }^{471}$.

Contudo, não se pode sonegar ao Parquet iniciativa para promover a execução coletiva, na forma autorizada pelo art. $15^{472}$ da Lei 7.347/85, visando excutir bens do patrimônio do devedor a fim de satisfazer todos os beneficiados pela sentença

\footnotetext{
${ }^{468}$ Nesse contexto, Luiz Carlos da Silva Araújo Filho exemplifica com: a culpa concorrente da vítima e o direito à compensação. No mesmo sentido: Dinamarco, Execução civil cit., p. 551, segundo o qual "O objeto desse especialíssimo processo de liquidação por artigos é mais amplo que o da autêntica e tradicional liquidação disciplinada no Código de Processo Civil", e então, "a ele não tem pertinência integral a regra da fidelidade".

${ }^{469}$ Nas palavras de Marcelo Abelha Rodrigues: "Ao contrário do que preconiza o art. 98 do CPC, nem a liquidação nem a execução da norma jurídica concreta referida no parágrafo anterior será coletiva, ainda que o legitimado (e desde que a lei autorize a legitimidade extraordinária) seja ente coletivo, pelo simples fato de que o direito tutelado é individual puro" (cf. Ponderações sobre a fluid recovery no art. 100 do CDC, in Revista de Processo, vol. 116, julho de 2004, p. 326).

470 Código Brasileiro de Defesa do Consumidor comentado cit., $10^{\mathrm{a}}$ ed., p. 158. Nessa linha, também: Yarshell, Observações a propósito da liquidação cit., p. 163; Érica Barbosa e Silva, Cumprimento de sentença nas ações coletivas, São Paulo, Atlas, 2009, p. 108; Luiz Guilherme Marinoni e Sérgio Cruz Arenhart, Curso de Processo civil cit., p. 332; e Zavascki, Processo coletivo cit., p. 185. Em sentido oposto, mencione-se Shimura, Tutela coletiva e sua efetividade cit., p. 181

${ }^{471}$ Assim, Luiz Rodrigues Wambier e Teresa Arruda Alvim Wambier, Anotações sobre a liquidação e a execução das sentenças coletivas, in Direito Processual Coletivo e o anteprojeto cit., p. 274 e Érica Barbosa e Silva, Cumprimento de sentença em ações coletivas cit., p. 108.

472 "Art. 15. Decorridos sessenta dias do trânsito em julgado da sentença condenatória, sem que a associação autora lhe promova a execução, deverá fazê-lo o Ministério Público, facultada igual iniciativa aos demais legitimados".
} 
genérica $^{473}$, principalmente na inércia de outros legitimados ${ }^{474}$. A propósito, a iniciativa do Ministério Público para requerer execução em prol dos direitos individuais de investidores de valores mobiliários também é permitida pela Lei 7.913/89.

Com mais razão, na busca pelo pagamento de indenização pelos danos provocados (fluid recovery), quando o processo, de certa forma, volta a ter contornos coletivos, a iniciativa do Ministério Público é inabalável ${ }^{475}$.

O meio adequado para o processamento da liquidação, sob a égide da Lei 11.232/2005, é o incidente processual, autuado em autos apartados da ação principal quando for provocado para a liquidação o mesmo juízo da fase de conhecimento ${ }^{476}$, a fim de dar seguimento em caráter autônomo cada uma das liquidações por artigos inauguradas.

Quando instaurada em foro diverso, do domicílio do consumidor, a liquidação e a execução terão natureza de um processo autônomo, porque dependentes da citação do réu ${ }^{477}$. Já na particular situação do interessado que, após ajuizar pretensão individual, tenha requerido a sua suspensão frente à ação coletiva e dela se beneficie com sentença condenatória, a ação, até então em fase de conhecimento, será convertida em liquidação da sentença genérica ${ }^{478}$.

Os pedidos de execução coletiva serão tantos quantos forem necessários para aglutinar créditos individualmente liquidados, o que explica a parte final do caput do art. 98 do CDC, quando se menciona o "ajuizamento de outras execuções” abrangendo as

\footnotetext{
473 Assumem essa posição: Grinover, Código Brasileiro de Defesa do Consumidor cit., 10a ed., pp. 158 e 160; Leonel, Manual do Processo Coletivo cit., p. 416; Mazzilli, A defesa dos interesses difusos em juízo cit., pp. 508 e 524; Shimura, Tutela coletiva e sua efetividade cit., p. 181.

${ }^{474}$ Acentuando a obrigatoriedade da atuação do Ministério Público em caso de inatividade do autor da demanda: Nelson Nery Junior, Código Brasileiro de Defesa do Consumidor cit., p. 252.

${ }^{475}$ Luiz Rodrigues Wambier e Teresa Arruda Alvim Wambier, Anotações sobre a liquidação cit., p. 274; Paulo Lucon e Érica Barbosa e Silva, Análise crítica da liquidação e execução cit., p. 178; Patrícia Miranda Pizzol, Liquidação nas ações coletivas cit., p. 186; Cândido Rangel Dinamarco, Instituições de Direito Processual cit., vol. IV, p. 162.

${ }^{476}$ Isso quando observada a regra, pelo autor coletivo, de que o foro competente para a liquidação e execução coletiva é o do juízo perante o qual se processou a fase de conhecimento (REsp 1243887/PR, Rel. Min. Luis Felipe Salomão, Corte Especial, j. 19/10/2011; CC 113.523/RJ, Rel. Min. Castro Meira, 1 ${ }^{\mathrm{a}}$ Seção, j. 23/02/2011), não se descartando, no entanto, que se valha da regra do art. 475-P, parágrafo único, do CPC.

${ }^{477}$ Sérgio Shimura, Tutela coletiva e sua efetividade cit., p. 150.

${ }^{478}$ Nessa linha: Shimura, cit. P. 183. Assim, discordamos de Gidi (Coisa julgada e litispendência cit., p. 197) para o qual a ação individual movida pelo consumidor, que requereu a suspensão de seu processo diante da ação coletiva, perde o objeto e deve ser extinta. Acreditamos que o requerimento de suspensão consiste na anuência do indivíduo em aderir ao pleito do autor coletivo e, portanto, transfere para o juízo da ação coletiva a competência para solucionar o seu pedido, antes manejado em sede individual. Na jurisprudência do STJ, vem sendo muito prestigiada a conversão da ação individual em liquidação de sentença genérica: AgRg no Ag 1144374/RS, Rel. Min. João Otávio de Noronha, 4a Turma, j. 14/04/2011; AgRg no Ag 1119376/RS, Rel. Min. Luis Felipe Salomão, $4^{\mathrm{a}}$ Turma, j. 02/12/2010; REsp 1189679/RS, Rel. Min. Nancy Andrighi, $2^{\mathrm{a}}$ Seção, j. 24/11/2010.
} 
vítimas cujas indenizações já tiverem sido apuradas. No atual modelo sincrético do processo, que reúne em um mesmo processo atividades cognitivas e executórias, vale a regra de que o cumprimento da sentença poderá ser requerido mais de uma vez.

\subsection{Fluid recovery e o fundo criado pela Lei 7.347/85}

Como já mencionado, a existência de verdadeira execução coletiva é a principal razão pela qual acreditamos que têm natureza condenatória as sentenças genéricas que reconhecem a responsabilidade do fornecedor pelos danos provocados aos consumidores.

De acordo com o art. 100 do $\mathrm{CDC}^{479}$, a execução coletiva se inicia com o intuito de que o réu seja compelido a pagar indenização compatível com a gravidade do dano, quando o número de habilitados individuais for pouco expressivo, em quantia a ser recolhida ao fundo criado pela Lei 7.347/85.

É certo que o legislador de 1985 se inspirou no remédio norte-americano da fluid recovery - criação da jurisprudência para as situações nas quais o dano é causado para um grupo grande de indeterminadas pessoas e, para não esvaziar a ordem de ressarcimento, o réu é obrigado a arcar com a reparação fluída.

E o mecanismo se tornou de bom proveito na realidade brasileira em que, seja por deficiente comunicação às vítimas, por seu desinteresse ou pela grande ocorrência de liquidações zero ${ }^{480}$, o sistema não pode conviver com uma insignificante eficácia concreta da sentença genérica.

Assim, por exemplo, se uma instituição financeira é condenada a restituir aos correntistas o correspondente a uma taxa mensal abusiva, descontada ao longo de 1 ano diretamente da conta de seus clientes, o crédito de uma vítima - que pode não superar um total de quantia de $\mathrm{R} \$ 50,00$ - não a incentiva a reclamá-lo. Mas, em um universo de 5 milhões de correntistas, o enriquecimento ilícito da instituição financeira é de tamanha expressividade (no exemplo, da ordem de $\mathrm{R} \$ 250.000 .000,00$ ), que se torna intolerável uma liquidação que, dependente exclusivamente da iniciativa individual, seja próxima do zero.

\footnotetext{
479 “Art. 100. Decorrido o prazo de um ano sem habilitação de interessados em número compatível com a gravidade do dano, poderão os legitimados do art. 82 promover a liquidação e execução da indenização devida".

${ }^{480}$ Assim: Yarshell, Observações a propósito da liquidação cit., p. 162.
} 
Daí a relevância da reparação fluida como instrumento de afirmação da norma concreta emanada do Estado, quando as indenizações pessoalmente aferidas não cumprirem esse papel. Nesse cenário, para afastar o risco de bis in idem - com a concomitância de execuções individuais em número significativo e da fluid recovery - a lei estipula que a reparação fluída é solução residual (art. 99 do $\mathrm{CDC}^{481}$ ).

A fim de assegurar que as indenizações individuais prefiram a fluid recovery, o sistema repele a execução coletiva dentro de 1 (um) ano a contar da comunicação acerca da condenação genérica definitiva ${ }^{482}$. E mesmo passado esse primeiro ano, o art. 99 do CDC institui mecanismo de preferência das indenizações individuais sobre a reparação fluida em caso de concurso de crédito.

Compreendido, assim, o papel da fluid recovery de estancar eventual inoperância da condenação genérica, não conseguimos justificá-la sem agregar, paradoxalmente, uma dimensão coletiva e indivisível também aos direitos que se apresentam como essencialmente individuais ${ }^{483}$. Concluímos então que, em caso de lesão a direitos individuais homogêneos, no qual a indenização fluida não tem fins reparatórios ${ }^{484}$, o bem jurídico tutelado pela fluid recovery é a relevância social do processo coletivo.

\footnotetext{
481 “Art. 99. Em caso de concurso de créditos decorrentes de condenação prevista na Lei n. ${ }^{\circ} 7.347$, de 24 de julho de 1985 e de indenizações pelos prejuízos individuais resultantes do mesmo evento danoso, estas terão preferência no pagamento. Parágrafo único. Para efeito do disposto neste artigo, a destinação da importância recolhida ao fundo criado pela Lei $\mathrm{n}^{\circ} 7.347$ de 24 de julho de 1985, ficará sustada enquanto pendentes de decisão de segundo grau as ações de indenização pelos danos individuais, salvo na hipótese de o patrimônio do devedor ser manifestamente suficiente para responder pela integralidade das dívidas".

482 Sobre a necessidade de aguardar o trânsito em julgado, v.: Marcelo Abelha Rodrigues, Ponderações sobre $a$ fluid recovery cit., p. 327; Elton Venturi, Liquidação e execução coletiva da fluid recovery referente à 'Sobra' do empréstimo compulsório cobrado pela União e não devolvido, in Revista de Processo, vol. 111, julho de 2003, p. 316; e Arruda Alvim, Código do Consumidor Comentado cit., p. 449. Contra: Luiz Rodrigues Wambier, Liquidação de sentença, São Paulo, Revista dos Tribunais, 1997, p. 273.

${ }^{483}$ Em sentido semelhante, observa Érica Barbosa e Silva: "há uma ampliação do sistema para permitir o cumprimento da responsabilidade civil pelo dano provocado. Isso porque mesmo sem a identificação especifica das pessoas atingidas por esse dano, o causador será condenado a uma obrigação de pagar. Para tanto, basta que a sentença reconheça a existência de um eventus danni. Ainda que essa condenação não seja direcionada para quem sofreu o dano, evitará que o causador experimente um enriquecimento ilícito, além de devolver esses valores para a sociedade, numa ampla perspectiva" (cf. Cumprimento de sentença nas ações coletivas cit., p. 136). Marcelo Abelha Rodrigues também obtempera: "a origem da verba arrecadada e destinada ao fundo federal dos direitos difusos, a que se refere o art. 100, parágrafo único, do CDC, provém, necessariamente, de uma demanda individual homogênea utilizada para se obter uma responsabilização por danos causados às vítimas de um mesmo evento danoso. Assim, se ontologicamente a origem desta demanda encontra-se acorrentada aos direitos individuais homogêneos, tem-se que teleologicamente encontra-se presa a uma finalidade difusa" (cf. Ponderações sobre a fluid recovery cit., p. 328).

${ }^{484}$ Mas compensatório, na medida em que a verba depositada no fundo se destina a remediar a lesão das vítimas mediante a promoção de atividades conexas, no interesse da coletividade lesada, o que leva Carlos Alberto de Salles a sustentar que a reparação fluida do direito brasileiro mais se assemelha ao superfund criado pela Cercla Act. de 1980 no direito norte-americano ao invés da fluid recovery (cf. Execução judicial em matéria ambiental, São Paulo, Revista dos Tribunais, 1999, pp. 310/315).
} 
Outro aspecto notado é que, conquanto a reparação fluida seja compensada com as indenizações individuais ${ }^{485}$, há risco concreto de bis in idem na medida em que depois de encerradas as liquidações individuais e a execução coletiva, novas execuções individuais podem ser iniciadas desde que respeitado o prazo prescricional ${ }^{486}$.

Aliás, em tema de fluid recovery, na esteira da mais abalizada doutrina ${ }^{487}$, vale o correto alerta de que o prazo de 1 (um) fixado no art. 100 do CDC não consiste em prazo prescricional para que as vítimas do ato ilícito promovam liquidação e execução individuais.

O prazo disciplinado por essa regra nada mais é do que um prazo processual mínimo (e não máximo) para a iniciativa execução coletiva da fluid recovery, sem prejuízo das indenizações fixadas individualmente em favor das vítimas, as quais a lei já predicou serem preferenciais.

Assim, desde que observado o prazo de prescrição fixado em lei para a hipótese que se queira examinar ${ }^{488}$, os interessados estão livres para reclamar indenização individual, via liquidação e execução de sentença coletiva, seja porque a fluid recovery não se sobrepõe às reparações individuais, seja porque não faria sentido que a lei quisesse incentivar novas ações de conhecimento para tutela condenatória, as quais deveriam ser ajuizadas naquele mesmo prazo da lei material.

Aproveitando o tema da prescrição, e seguindo as lições de Ada Pellegrini Grinover $^{489}$, discordamos da posição adotada pela Segunda Seção do STJ no julgamento do RESP 1070896/SC (Rel. Ministro Luis Felipe Salomão, j. 14/04/2010). Conforme já enunciou a Professora Ada Pellegrini, o erro está em transportar para a ação civil pública o prazo exíguo previsto na lei da ação popular cujo objetivo é, além de anular ato administrativo, aplicar sanções aos agentes públicos.

${ }^{485}$ Sobre a compensação: Grinover, Código Brasileiro de Defesa do Consumidor comentado cit., $10^{\mathrm{a}} \mathrm{ed} ., \mathrm{p}$. 165; Érica Barbosa e Silva, Cumprimento de sentença em ações coletivas cit., p. 138; e Arruda Alvim, Código do Consumidor Comentado cit., p. 452.

${ }^{486}$ Essa é uma das preocupações externadas por Marcelo Abelha Rodrigues, in Ponderações sobre a fluid recovery cit., p. 331.

${ }^{487}$ Grinover, Código Brasileiro de Defesa do Consumidor cit., 10 a ed., p. 154; Arruda Alvim, Código do Consumidor Comentador cit., p. 445; Paulo Lucon e Érica Barbosa e Silva, Análise crítica da liquidação e execução cit., pp. 173 e 180; Pizzol, Liquidações nas ações coletivas cit., p. 184; Wambier, Liquidação de sentença cit., 1997, p. 278; Sérgio Cruz Arenhart, O regime da prescrição em ações coletivas, in Em defesa de um novo sistema de processos coletivos cit., p. 614.

${ }^{488}$ Como já cristalizado na Súmula 150 do STF: "Prescreve a execução no mesmo prazo de prescrição da ação".

${ }^{489}$ Código Brasileiro de Defesa do Consumidor comentado cit., $10^{\mathrm{a}}$ ed., p. 155. 
Já na tutela reparatória em benefício de titulares de direitos individuais homogêneos, a situação é diversa e deve ser regulado pela lei civil. Assim, às pretensões de obtenção de expurgos inflacionários - relativos aos planos econômicos editados no fim da década de 1980 e início da década de 1990 - aplica-se o prazo vintenário previsto no art. $177^{490}$ do Código Civil de 1916 em conjunto com a regra transitória do art. $2.028^{491}$ do Código Civil de 2012.

Para lesões causadas nos dias de hoje, em contrário, sob a égide tanto do Código Civil de 2002 (art. 206, §3º, inciso V) quanto do Código de Defesa do Consumidor (art. 27), os prazos prescricionais passam a ser mais enxutos: de 3 (três) anos para as pretensões de reparação civil, em geral, e de 5 (cinco) anos para a reparação civil pelos danos causados pelo fato do produto ou serviço, respectivamente ${ }^{492}$.

Também vale mencionar que a previsão do prazo de 1 (um) ano contida no art. 100 do CDC não conflita, no presente estudo, com o prazo mais exíguo tratado no art. 15 da Lei 7.347/85. Isso porque na reparação fluida pela lesão de direitos difusos ou coletivos, a indenização coletiva é o fim precípuo do processo ${ }^{493}$, cabendo ao Ministério Público promover a execução prontamente se em 60 (sessenta) dias o autor não o fizer. Porém, quando se busca a reparação de lesão a direitos individuais homogêneos, a fluid recovery é lógica e cronologicamente residual, justificando o maior lapso temporal reservado para a execução exclusivamente pelos danos pessoais.

\footnotetext{
490 “Art. 177. As ações pessoais prescrevem, ordinariamente, em vinte anos (...)".

491 “Art. 2.028. Serão os da lei anterior os prazos, quando reduzidos por este Código, e se, na data de sua entrada em vigor, já houver transcorrido mais da metade do tempo estabelecido na lei revogada".

${ }^{492}$ Exceção deve ser feita às situações materiais que tenham regulamentação própria. Assim, por exemplo, o STJ já firmou o entendimento de que, com fulcro nos arts. 36 da Lei 6.435/77, 103, parágrafo único, da Lei 8.213/91 e 19, parágrafo único, do Regulamento de Planos e Benefícios, "A ação de cobrança de parcelas de complementação de aposentadoria pela previdência privada prescreve em cinco anos" (Súmula 291).

493 "Na primeira hipótese, ou seja, da liquidação coletiva, a legitimidade para a liquidação e execução da sentença é preferencialmente do próprio autor da ação condenatória" (cf. Pizzol, Liquidação cit., p. 197).
} 


\section{PARTE III - OUTRAS TÉCNICAS DE RESOLUÇÃo dOS LITÍGIOS DE INTERESSES INDIVIDUAIS HOMOGÊNEOS NO DIREITO VIGENTE E PROJETADO}

Examinado o papel do processo coletivo na judicialização dos interesses individuais homogêneos, não podemos ignorar que nos últimos anos a ciência processual brasileira tornou-se rica no estudo - e na consagração legislativa - de mecanismos que cumprem o mesmo propósito. Esses mecanismos são o objeto de estudo deste capítulo.

A par de detalhes procedimentais que não se relacionam com o objeto deste estudo, procuraremos assimilar em que pontos os mecanismos a seguir tratados convergem, positiva ou negativamente, para a tutela de direitos individuais homogêneos.

\section{Improcedência da demanda com fulcro no art. 285-A do CPC e súmula impeditiva de recursos}

Dentre os mecanismos positivados e mais notáveis de resolução de processos repetitivos, na atual busca de eficiência do Judiciário e de uniformização das decisões, encontra-se o recente art. 285-A do Código de Processo Civil, resultado da Lei n. $11.277 / 2006$.

Por aquele dispositivo, em linhas gerais, o juiz está autorizado a proferir liminarmente, ou seja, antes da citação do réu, sentença de improcedência da demanda, com base em convencimento firmado em casos idênticos. É um exemplo do denominado efeito superlativo da jurisprudência ${ }^{494}$ que, em tempos de valorização dos precedentes, incentiva a sumarização do procedimento para racionalizar o julgamento de pretensões repetitivas $^{495}$.

\footnotetext{
${ }^{494}$ Mancuso, Divergência Jurisprudencial e Súmula Vinculante, $3^{\text {a }}$ ed., São Paulo, Revista dos Tribunais, 2007, p. 155.

${ }^{495}$ A novidade não passou ilesa pela comunidade jurídica, tendo o Conselho Federal da OAB ajuizado ação direta de inconstitucionalidade (ADI 3695 - que até a conclusão deste trabalho aguarda designação de novo relator), impugnando a utilização de sentença emprestada por ser incompatível com o contraditório. Na doutrina, representando a corrente que considera o dispositivo inconstitucional, por violação ao devido processo legal, à ampla defesa do réu e ao princípio dispositivo, v.: Nelson Nery Júnior e Rosa Maria de Andrade Nery, Código de Processo Civil comentado e legislação extravagante, $10^{\mathrm{a}}$ ed., São Paulo, Revista dos Tribunais, 2008, p. 556. Em sentido contrário, preconizando que o mecanismo impõe um contraditório diferido e, portanto, consentâneo com a garantia constitucional da celeridade (Cf. Mudanças estruturais no processo civil brasileiro, in Revista de Direitos e Garantias Fundamentais, n. 1, 2006, p. 217).
} 
Com igual escopo, aquele mesmo diploma (Lei n. 11.277/2006) embutiu às súmulas dos tribunais superiores a aptidão de obstar o recebimento de apelação contra sentença em consonância com aqueles enunciados.

Um primeiro aspecto a ser destacado é que o artifício da improcedência liminar (ou julgamento prima facie $e^{496}$ ), para a resolução de demandas repetitivas, resulta de um diálogo entre processos autônomos que, sem provocação das partes, mas por atividade jurisdicional, estabelecerão um canal de "intercâmbio de informações" ${ }^{497}$. Difere, portanto, da ação coletiva que, para minimizar a multiplicação de processos idênticos, estabelece um canal por onde é transportada in utilibus a imutabilidade da coisa julgada.

Além disso, é possível inferir que a técnica da improcedência liminar tem um espectro de aplicação, a rigor, mais amplo do que sugere a redação do dispositivo e relativamente ao processo coletivo de defesa de interesses individuais homogêneos. Segundo a elocução do art. 285-A da lei processual, o julgamento antecipado de improcedência poderá ocorrer quando o juiz tenha se convencido em anteriores casos idênticos em torno de questão exclusivamente de direito.

Como já expressou a doutrina, “A expressão casos idênticos não é sinônima de ações idênticas" 498 e deve ser lida como "causas de pedir similares" ${ }^{\text {"499 }}$. Nesse universo é fácil inserir qualquer segmento de direitos individuais homogêneos, na medida em que, mais do que similaridade, o requisito da origem comum pressupõe a conexão da causa de pedir das diversas pretensões individuais.

Entretanto, na noção de casos idênticos também se incluem aqueles processos cuja homogeneidade não é suficientemente intensa a justificar o tratamento coletivo da controvérsia e nem há razoável dispersão dos interessados a tornar a tutela coletiva mais eficiente ${ }^{500}$, a despeito de empiricamente repetitivos os pedidos. Sob esse

\footnotetext{
${ }^{496}$ Cf. Eduardo Cambi, Julgamento prima facie (imediato) pela técnica do art. 285-A do CPC, in Revista dos Tribunais, vol. 854, dezembro de 2006, disponível em Revista dos Tribunais on line, acesso em 1\%/10/2011.

497 A expressão é de Ruy Zoch Rodrigues, autor de sólida e ousada obra sobre as ações repetitivas: Ações repetitivas cit., p. 164.

${ }^{498}$ Cf. Eduardo Cambi cit.

${ }^{499}$ Cf. Ruy Zoch Rodrigues, op. cit., p. 157.

${ }^{500}$ Assim, Ruy Zoch Rodrigues pondera: "em reforço à ideia de que as repetições não se inserem todas no direito coletivo, embora este seja o seu núcleo de interesse maior, vejam-se as hipóteses em que o número de pessoas envolvidas em relações similares não chega a ser tamanho que justifique aquele tipo de tutela, mas que apresentam repetições em todas as unidades do conjunto (p. ex.: o consumo de medicamente defeituoso por poucas pessoas (...). Também quando, havendo origem comum entre vários direitos, o nível de homogeneidade é rarefeito e, por isso, a tutela coletiva releva-se menos eficiente que as individuais" (p. 142).
} 
ângulo, portanto, o propósito do legislador merece aplausos pois consegue conferir tutela jurisdicional célere a uma dimensão de conflitos que não pode ser gerida coletivamente.

Em outro patamar, quando a lei exige que a repetição verse sobre questão exclusivamente de direito não quer dizer que alegações fáticas devem ser excluídas de seu campo de aplicação. Como lembra Ruy Zoch, "nessas demandas, como em todas, o suporte de fato constitui um prius lógico inseparável da definição do direito",501.

Sucede que a regra permite ao juiz não investigar a veracidade dos fatos afirmados na inicial (sequer instaurando-se autêntica controvérsia fática), tomando-os como verdadeiros sem que com isso prejudique o réu que não foi citado. Assim, se o magistrado se convence de que, como fundamento de improcedência de embargos à execução, o avalista não pode opor em face do credor as exceções pessoais do avalizado, o juiz sequer perquire a causalidade da nota promissória emitida em estrita vinculação a contrato de compra e venda.

Pode servir de consolo a recorribilidade da improcedência prima facie, sabido que não se trata de canal para o transporte de imutabilidade de coisa julgada, mas intercâmbio entre demandas para valorização da jurisprudência do juízo e racionalização (sem supressão) do procedimento. De fato, o exame da matéria pelo órgão superior pode reduzir a preocupação com eventual equívoco da decisão de primeiro grau seja quanto à aplicação do direito à hipótese concreta ou quanto à afirmação sobre a similaridade dos casos.

Porém, mesmo assim nos intriga o emprego não raro - e patológico - de instrumentos direcionados tão somente a solucionar a sobrecarga do Judiciário - em grau tal que, desde a primeira instância até o segundo grau de jurisdição, neutralizam o reexame da causa e, nas instâncias superiores, acabam por anular as chances de revisão dos precedentes por órgão colegiado ${ }^{502}$. Assim, pode ser questionável o emprego conjunto da faculdade conferida ao juiz pelo art. 285-A do CPC com a imperatividade da súmula impeditiva de recursos (art. 518, $\S 1^{\mathrm{o} 503}$ ).

\footnotetext{
${ }_{501}$ Cf. Ações coletivas cit., pp. 158/159.

502 No direito norte-americano, é conhecida a dedicação dos tribunais ao chamado overruling, dado que a revogação dos precedentes pode surtir efeitos prospectivos, alcançando também situações pretéritas. Sobre o tema, a título de referência recente, menciona-se texto de Luiz Guilherme Marinoni, Eficácia temporal da revogação da jurisprudência consolidada dos Tribunais Superiores, in Revista dos Tribunais, vol. 906, abril de 2011, p. 255 e seguintes.

503 “O juiz não receberá o recurso de apelação quando a sentença estiver em conformidade com súmula do Superior Tribunal de Justiça ou do Supremo Tribunal Federal”.
} 
Não é difícil imaginar situações extremas, nas quais: a apelação contra a improcedência prima facie não seja recebida já em primeira instância, se estiver em consonância com Súmula do STF ou do STJ, como autoriza o art. 518, §1º, do CPC; venha a ser improvido monocraticamente, com fulcro nos arts. 522 e 557 do CPC, eventual agravo contra o não recebimento da apelação, ao argumento de ser dominante o entendimento de que o juiz de primeiro grau pode negar seguimento a recurso manifestamente inadmissível. Afinal, não são poucas as vozes no sentido de que, para além de convencimento consolidado do juízo sentenciante, a norma também autoriza a improcedência com base em precedente firmado nos tribunais superiores ${ }^{504}$.

É conhecido o ensinamento de que o duplo grau de jurisdição não se insere no rol de garantias constitucionais ${ }^{505}$, mas isso não nos exime de cuidar para que os conflitos repetitivos e de massa não sejam retaliadas por uma justiça de atacado.

Portanto, se desvirtuada, e aplicada a pretensões judiciais homogêneas de indivíduos que deliberadamente optaram por não se vincularem ao desfecho de uma demanda de grupo - a técnica corrompe de tal modo o sistema das ações coletivas que, no extremo, impõe ao indivíduo decisão desfavorável sem que lhe tenha sido dado optar por ser representado, adequadamente ou não, para o convencimento do juiz e tribunal a respeito da tese jurídica vencedora.

Por sua vez, emprego equilibrado da improcedência liminar de ações repetitivas veiculando direitos homogêneos foi aventado pelo Ministro Sidnei Beneti no já tratado RESP 1110549/RS: “o processo individual poderá ser julgado de plano, por sentença liminar de mérito (CPC, art. 285-A), para a extinção do processo, no caso de insucesso da tese na Ação Civil Pública".

\footnotetext{
${ }^{504}$ Assim: Ruy Zoch Rodrigues, Ações coletivas cit., p. 161; Fernando da Fonseca Gajardoni, O princípio constitucional da tutela jurisdicional sem dilações indevidas e o julgamento antecipadíssimo da lide, in Revista de Processo, vol. 141, novembro de 2006, p. 150, disponível em Revista dos Tribunais on line, acesso em 5/11/2011; Luiz Guilherme Marinoni, Ações repetitivas e julgamento liminar, in Revista dos Tribunais, vol. 858, abril de 2007, disponível em Revista dos Tribunais on line, acesso em 5/11/2011; Eduardo Cambi, Julgamento prima facie cit., Cândido Rangel Dinamarco, Instituições de Direito Processual cit., vol. III, p. 413; Iure Pedroza Menezes, O precedente judicial e o art. 285-A do CPC, disponível em <http://bdjur.stj.gov.br/xmlui/bitstream/handle/2011/9799/O_\%20Precedente_Judicial_e_o_Art._285-A.pdf?sequence=1>, acesso em 5/11/2011; João Francisco Naves da Fonseca, $O$ julgamento liminar de improcedência da demanda (art. 285-A): questões polêmicas, disponível em <http://www.tre-pb.gov.br/eje/pdf/Novo_CPC_Artigo.pdf>, acesso em 5/11/2011. E na jurisprudência: REsp 1279570/MG, Rel. Min. Mauro Campbell Marques, $2^{\mathrm{a}}$ Turma, j. 08/11/2011; e REsp 1109398/MS, Rel. Min. Luis Felipe Salomão, $4^{a}$ Turma, j. 16/06/2011.

${ }^{505}$ Oreste Nestor de Souza Laspro, Duplo grau de jurisdição no direito processual civil, São Paulo, Revista dos Tribunais, 1995, p. 156.
} 
Chegamos a nos manifestamos aqui pelo equívoco do julgado em suspender coercitivamente, por conta de recurso pendente de julgamento, todas as ações individuais em curso. Entretanto, enxergamos muita prudência no particular modelo, acima transcrito, de gestão de processos repetitivos, que, após o julgamento de improcedência do processo coletivo, estejam em fase liminar e possam seguir o caminho trilhado no art. 285-A do CPC.

A ênfase ao julgamento definitivo da ação coletiva se justifica porque, na nossa opinião, antes do desfecho do processo coletivo, o legitimado ordinário poderá optar por se vincular ou não pelo resultado da ação movida pelo legitimado extraordinário; mas, após o trânsito em julgado da ação coletiva, assegurada a melhor representação dos interesses das vítimas no âmbito coletivo, a improcedência é resultado de juízo apto a ser aproveitado, pela regra do art. 285-A do CPC, a todas as demandas individuais que estejam em fase de despacho inicial ${ }^{506}$.

Feitas essas breves considerações, é inegável que o Judiciário tem em mãos instrumento poderoso para racionalizar a gestão dos processos repetitivos. Todavia, o operador deve cuidar para que, no enfrentamento de múltiplas pretensões veiculando direitos homogêneos, a técnica da improcedência liminar ou prima facie não colida com o microssistema processual coletivo, o qual é marcado por garantias processuais peculiares que não têm espaço no procedimento sumarizado do art. 285-A do $\mathrm{CPC}^{507}$.

\section{Incidente de resolução de demandas repetitivas}

Um dos carros chefes do projeto do novo Código de Processo Civil é o chamado incidente de resolução de demandas repetitivas, previsto nos arts. 930 e seguintes (projeto em trâmite na Câmara sob o n. 8.046/2010). Conforme descrito na Exposição de Motivos, o processo-modelo foi inspirado no direito germânico (Musterverfahren) e atua

\footnotetext{
${ }^{506}$ Semelhante raciocínio, inclusive, é objeto do art. 34 do Projeto de nova Lei da Ação Civil Pública: "Os efeitos da coisa julgada coletiva na tutela de direitos individuais homogêneos não prejudicarão os direitos individuais dos integrantes do grupo, categoria ou classe, que poderão propor ações individuais em sua tutela. $\S 1^{\circ}$ Não serão admitidas novas demandas individuais relacionadas com interesses ou direitos individuais homogêneos, quando em ação coletiva houver julgamento de improcedência em matéria exclusivamente de direito, sendo extintos os processos individuais anteriormente ajuizados".

${ }^{507}$ Reforçando esse pensamento, eis as precisas considerações de Ruy Zoch Rodrigues que preconiza: "ajustar a compreensão do fenômeno da cultura que vai se formando paulatinamente na consciência dos operadores, evitando equívocos, por um lado, e acelerando a adoção de oportunidades que o contexto oferece, por outro, tanto no uso consciente e sem constrangimentos de técnicas próprias da gestão de conjuntos e da própria burocracia para julgar ações repetitivas, como a percepção de novos institutos" (op. cit., p. 154).
} 
na "identificação de processos que contenham a mesma questão de direito, que estejam ainda no primeiro grau de jurisdição, para decisão conjunta".

Os méritos são atribuídos ao sistema germânico, mas em realidade o Inglaterra se antecipou à Alemanha (Gesetz zur Einführung von KapitalanlegerMusterverfahren de $2005^{508}$ ) e Áustria (ZPO com a reforma de $2004^{509}$ ), e em 2000 inseriu nas Civil Procedure Rules as group litigation orders ${ }^{510}$.

O procedimento consiste, em suma, na provocação pelo juiz, pelas partes, Ministério Público ou Defensoria Pública, do Tribunal hierarquicamente superior, para que, após a mais ampla divulgação possível, julgue o incidente com aplicação da tese jurídica adotada a todos os processos pendentes, em primeira e segunda instâncias (que ficam suspensos com o recebimento do incidente), na área da jurisdição do respectivo tribunal, e que versem a mesma questão de direito.

Na prática, o julgamento de um processo-piloto - eleito como representativo da controvérsia de direito respeitante a diversos processos simultaneamente em curso - é aproveitado para resolver a questão comum e, assim, promove o tão relevante anseio uniformização dos julgamentos enquanto também desafoga o Judiciário, hoje em meio à multiplicação dos conflitos de massa.

De acordo com a dicção do art. 930 do projeto, o incidente tem lugar quando "identificada controvérsia com potencial de gerar relevante multiplicação de processos fundados em idêntica questão de direito e de causas grave insegurança jurídica, decorrente do risco de coexistência de decisões conflitantes”.

Nesses termos, se aprovado o projeto, ficará institucionalizada a intolerância do sistema a decisões logicamente colidentes sobre uma controvérsia homogênea. Por tal ângulo, a medida é providencial, mas não dispensaria o legislador de certas preocupações que já são desenvolvidas no âmbito do microssistema de processos coletivos - e que, não obstante o engajamento da doutrina e demais operadores, não levaram à redução vertiginosa de ações individuais.

\footnotetext{
${ }^{508}$ Fonte: 〈http://www.buzer.de/gesetz/7414/index.htm>, acesso em 1/12/2011.

${ }^{509}$ De acordo com Walter Rechberger, relatório nacional, in Os processos coletivos nos países de civil Law e common law cit., p. 147.

${ }^{510}$ Que, segundo a regra n. 19.10, consiste em: "an order made under rule 19.11 to provide for the case management of claims which give rise to common or related issues of fact or law (the 'GLO issues')"; fonte: <http://www.justice.gov.uk/guidance/courts-and-tribunals/courts/procedure-rules/civil/contents/parts/part19.htm\#IDA2PMCC〉, acesso em 1/12/2011.
} 
De início foi cunhado de incidente de coletivização de processos pelos membros da Comissão responsável pela elaboração do anteprojeto, conquanto não haja autêntica coletivização, na medida em que é preservada a autonomia procedimental de cada um dos processos ${ }^{511}$.

Em diversos aspectos o projeto superou os parâmetros vigentes no gênero processual do julgamento por amostragem e tem muitos pontos de contato com o processo coletivo autêntico, pois a autonomia das pretensões individuais é minimizada ${ }^{512}$.

No que se refere à legitimidade ${ }^{513}$, o projeto no fundo desviou-se do quadro de legitimação em matéria coletiva, permitindo que tanto o autor quanto o réu ${ }^{514}$ de ação repetitiva - forjem um instrumento processual que terá eficácia expandida. Na figura do autor, estão concentrados naturalmente todos os legitimados coletivos previstos no art. 82 do CDC, mas, na forma do projeto, no conceito também se insere o indivíduo ou membro isolado do grupo, de quem não se afere a representatividade adequada, nos termos atuais do projeto.

É certo que foi prevista a participação de interessados de quem serão ouvidas as razões em torno da questão de direito controvertida, conforme preceitua o art. $935^{515}$, mas a dicção do projeto é deficiente, pois confere direito de voz desacompanhado de adequada representação. Como visto em linhas precedentes, o controle da pertinência temática (e o interesse homogêneo na causa pelo membro do grupo) não garante a representatividade ${ }^{516}$.

${ }^{511}$ Cf. Carla Andrea Barbosa, Diego Martinez Fervenza Cantoario, O incidente de resolução de demandas repetitivas e o projeto de Código de Processo Civil: apontamentos iniciais, in $\mathrm{O}$ novo Processo Civil brasileiro: direito em expectativa (Luiz Fux coord.), Rio de Janeiro, Forense, 2011, p. 441.

512 É precisa a lição de Vigoriti ao examinar as categorias de complex litigation já experimentadas pelo direito europeu: representative class action (ações associativas), group litigation (ações movidas pelo membro do grupo) e test-cases (demanda não necessariamente coletiva) (cf. L'azione risarcitoria di classe: sollecitazioni europee, resistenze italiane, in Revista de Processo, vol. 180, fevereiro de 2010, p. 245, disponível em Revista dos Tribunais on line).

513 "Art. 930. (...) $\S 1^{\circ}$. O pedido de instauração do incidente será dirigido ao Presidente do Tribunal: I - pelo juiz ou relator, por ofício; II - pelas partes, pelo Ministério Público ou pela Defensoria Pública, por petição".

${ }_{514}$ A propósito, a legitimação do réu pode produzir o mesmo efeito prático de uma ação coletiva passiva, para vincular quem é parte de processos em curso.

515 “Art. 935. O Relator ouvirá as partes, e os demais interessados, inclusive pessoas, órgãos e entidades com interesse na controvérsia, que, no prazo comum de quinze dias, poderão requerer a juntada de documentos, bem como as diligências necessárias para a elucidação da questão de direito controvertida; em seguida, no mesmo prazo, manifestar-se-á o Ministério Público".

${ }^{516}$ Conforme comentou Eduardo Talamini em audiência pública realizada em 16/4/2010: "A pura e simples atribuição ao ministério público dessa tarefa de conduzir o processo piloto - como já cogitou a comissão não deve resolver tal problema. Com a devida venia, há aí injustificável crença na superioridade das iniciativas oficiais. É também e sobretudo o vigor da sociedade civil que poderá viabilizar uma representação adequada. Então, e sem prejuízo da relevante participação do ministério público, a ação piloto deve poder ser 
Ainda, julgado o incidente, na forma prevista pelos arts. 938 e $941^{517}$ do projeto, os autores das demandas repetitivas não poderão combater a decisão condutora por incidente recursal no âmbito do seu próprio processo. Caberá a todos os interessados, segundo dispõe o art. $940^{518}$, interpor recurso especial ou extraordinário nos autos do incidente. Ao lado do inconveniente da interposição de recurso especial ou extraordinário por terceiro interessado - que no incidente corresponde às múltiplas partes cujos processos estejam a ele vinculados - a medida seria dispensável caso se aferisse a representatividade do recorrente.

E mais, além de serem válidas as considerações já escritas a respeito do art. 285-A do CPC, no que concerne à similaridade da questão de direito, acrescenta-se que a decisão do incidente ainda tem uma eficácia que, além expandida, é mais intensa (relativamente ao resultado de um processo coletivo), pois vinculará pro et contra os titulares do direito em comum. Isto é, o incidente de resolução de processos repetitivos, que pode girar em torno de um núcleo de variável homogeneidade (desde a mais branda até a mais densa), poderá sobrepor-se a uma ação coletiva e impor consequências mais restritivas aos titulares de direitos homogêneos.

E não se pode perder de vista também que, ao contrário dos modelos estrangeiros de processo-piloto, em que é voluntária a adesão (opting-in), a proposta nacional prevê a suspensão obrigatória das demandas repetitivas ${ }^{519}$, o que nos parece, com a devida vênia, providência autoritária.

Afinal, se é verdade que o povo brasileiro clama por uma justiça mais célere, não menos verdade é que a perspectiva de um julgamento célere (dentro de 6 meses, como estima o art. 939 do projeto) e uniforme incentivaria a adesão voluntária. A vinculação obrigatória, aliás, soa ainda mais imprópria diante da falta de critérios para a

conduzida concorrentemente pelo seu autor original e alguns daqueles amici curiae que se revelem como os mais preparados, os mais aptos para a defesa da tese. É o que eu chamaria de contributividade adequada - a ser aferida pelo juiz da causa" (disponível em <http://www.migalhas.com.br/Quentes/17,MI106902,41046Manifestacao+do+Professor+Eduardo+Talamini+sobre+a+reforma+do+CPC >; acesso em 7/05/2010).

517 “Art. 938. Julgado o incidente, a tese jurídica será aplicada a todos os processos que versem idêntica questão de direito e que tramitem na área de jurisdição do respectivo tribunal. (...) Art. 941. Não observada a tese adotada na decisão proferida no incidente, caberá reclamação para o tribunal competente".

518 “Art. 940. O recurso especial ou extraordinário interposto por qualquer das partes, pelo Ministério Público ou por terceiro interessado será dotado de efeito suspensivo, presumindo-se a repercussão geral de questão constitucional eventualmente discutida. Parágrafo único. Na hipótese prevista no caput, interpostos os recursos, os autos serão remetidos ao tribunal competente, independentemente da realização de juízo de admissibilidade na origem".

519 “Art. 934. Admitido o incidente, o presidente do tribunal determinará, na própria sessão, a suspensão dos processos pendentes, em primeiro e segundo graus de jurisdição”. 
aferição da representatividade adequada daquele se que dirá porta-voz dos interesses em debate no incidente.

Sabemos que revogar os arts. 103 e 104 do CDC não é o escopo do Projeto do novo Código de Processo Civil, seja porque não estão listados nas disposições finais sobre as leis revogadas ou pela conveniência de uma disciplina autônoma dos processos coletivos (que será resguardada, de um modo ou de outro, com a aprovação do Projeto n. 5.139/2009 ou com a criação do aventado novo Código de Defesa do Consumidor).

Por isso, se aprovado o projeto de novo CPC nos seus termos atuais, será preciso estabelecer uma convivência harmônica entre os dois diplomas.

Assim, na ausência de ação coletiva, admitidos que é impensável abandonar um esquema de gestão dos processos repetitivos. Mas, para não invadir o particular terreno de incidência das regras do microssistema processual coletivo, pervertendo garantias ali arraigadas, propomos que sejam poupadas do incidente as pretensões individuais que, suspensas ou não, veiculem direitos homogêneos objeto de ação coletiva em curso.

Relativamente às múltiplas ações individuais que possam ser ajuizadas após o julgamento definitivo de uma ação coletiva, vale a técnica do art. 285-A, do CPC, como afirmamos supra. Daí ser incorreto defender que o incidente de resolução de processos repetitivos tenha sempre efeito prospectivo. Quem o tem, já no direito vigente, é preferencialmente a ação de índole coletiva ${ }^{520}$.

Aliás, vale frisar que o sistema germânico, no qual se inspirou a Comissão de Juristas responsável pela elaboração do anteprojeto de novo Código, só conhece leis setoriais em matéria coletiva, visto que naquele país é pouco comum a solução adjudicada das controvérsias mais significativas ${ }^{521}$.

\footnotetext{
${ }^{520}$ Em sentido semelhante, Antonio de Passo Cabral observa criticamente tratar-se de "mecanismos que devem conviver, e não se sobrepor: as ações coletivas de formato representativo possuem papel indispensável no cenário nacional, em especial pela desinformação e pobreza que assolam grandes populações em nosso país. Por outro lado, o esquema das ações de grupo não representativas, além de preservar a higidez de tradicionais garantias processuais, mantém relevante espaço de aplicação em uma série de hipóteses, como nas demandas referentes aos investidores no mercado de capitais, causas em matéria tributária ou em algumas demandas propostas por associações, quando os associados não forem hipossuficientes" (cf. O novo procedimento-modelo (musterverfahren) alemão: uma alternativa às ações coletivas, in Revista de Processo, vol. 147, maio de 2007, p. 123).

${ }^{521}$ Raros exemplos de instrumentos processuais coletivos são encontrados na legislação específica contra as práticas de restrição à concorrência e contra a concorrência desleal e sobre as condições gerais dos negócios, cf. Antonio do Passo Cabral, op. loc. cit., disponível em Revista dos Tribunais on line. A propósito, a Musterprozesse foi instituída em caráter experimental, a partir de uma necessidade prática de resolução de
} 
Narrando uma realidade completamente diferente da nossa, o professor alemão Norbert Reich, da Faculdade de Direito da Universidade de Bremen, assevera que: "Consumidores não mostram muito um poder coletivo, um poder semelhante ao de um cartel; eles unem suas demandas sob uma liderança hábil. Consumidores não foram transformados de maximizadores de lucro individual, em agentes de solidariedade. Suas demandas têm tido, espera-se, efeitos positivos ('spin-off-effects') sobre outros consumidores e sobre a influência do consumidor em geral" ${ }^{1,522}$.

Por sua vez, também é conhecida a resistência dos ingleses ao modelo dos processos por representação (ou class actions). Conforme acentua com propriedade Neil Andrews, "os tribunais interpretaram a rule de forma restritiva. Essa medida reduziu muito a oportunidade de se usar esse tipo de ação como meio de se obter indenização em nome de seus membros individuais da classe representada" ${ }^{\text {"523, }}$, daí o grande prestígio que as group litigation orders ganharam na common law inglesa.

Enfim, colhe-se de tudo isso que o mecanismo do processo-modelo tem muito a contribuir com a resolução de processos repetitivos no Brasil, desde que esteja bem sintonizado com as regras em favor da tutela coletiva dos direitos homogêneos. Se o Congresso Nacional conscientizar-se do caráter experimental desse instrumento na vivência estrangeira (de países desabituados com a tutela coletiva de direitos individuais), poderá transportá-lo adequadamente para a realidade brasileira.

\section{Arbitragem}

Na medida em que o CPC de 1973 (nos revogados arts. 1072 e seguintes) conferia à arbitragem papel secundário frente à jurisdição estatal no Brasil, não há dúvida de que a Lei 9.307/96 lhe deu nova roupagem. A sentença do árbitro foi alçada ao mesmo patamar da sentença proferida pelo juiz togado, na medida em que lhe foram outorgados

pretensões múltiplas de investidores da empresa Deutsche Telekom AG (cf. Guilherme Rizzo Amaral, Efetividade, segurança, massificação e a proposta de um 'incidente de resolução de demandas repetitivas', in Revista de Processo, vol. 196, junho de 2011, p. 237, disponível em Revista dos Tribunais on line).

${ }^{522}$ E conclui: "Processos modelos (Musterprozesse) freqüentemente usados em demandas comerciais e concorrenciais, deveriam também ser encorajados em demandas de consumidores (Koch, 1990). O procedimento legal tradicional na Alemanha tem sido pouco receptivo a tais tipos de ação coletiva" (cf. Algumas proposições para a filosofia da proteção do consumidor, Revista dos Tribunais, vol. 728, junho de 1996, p. 11 e seguintes; disponível em Revista dos Tribunais on line).

${ }^{523}$ Cf. O moderno processo civil: formas judiciais e alternativas de resolução de conflitos na Inglaterra (orient. trad. Teresa Arruda Alvim Wambier), São Paulo, Revista dos Tribunais, 2009, pp. 340 e 345. 
autoridade de coisa julgada, força executiva e, assim, o caráter jurisdicional ${ }^{524}$ enquanto substitutivo da vontade do particular.

Aliás, conforme enuncia o Professor Rodolfo de Camargo Mancuso, a valorização dos instrumentos alternativos de resolução das controvérsias - instâncias por vezes mais adequadas para a solução de conflitos massificados, por sua especialização, celeridade e não-litigiosidade - pressupõem uma revisita do conceito de jurisdição, a fim de se caminhar para a quebra do monopólio da jurisdição estatal ${ }^{525}$.

A arbitragem em particular precisou derrotar essa primeira barreira no direito brasileiro, mas enfim foi vencida a tese de que a Lei n. 9.307/96 seria inconstitucional $^{526}$. As atenções, então, passam a se concentrar nas chamadas condições gerais de arbitrabilidade, que são, grosso modo, a disponibilidade do direito e a inexistência de interesse de incapaz, como decorre do art. $1^{\text {o527 }}$ da Lei da Arbitragem.

A esse respeito, em obra atual intitulada Arbitragem em Contratos Administrativos, Carlos Alberto de Salles deu destaque à distinção entre reserva de jurisdição e indisponibilidade de determinados bens jurídicos ${ }^{528}$. Assim, para admitir a

\footnotetext{
${ }^{524}$ Assim para a maioria da doutrina, a saber: Cf. Carlos Alberto Carmona, Arbitragem e processo - um comentário à Lei $n^{\circ}$ 9.307/96, $3^{\mathrm{a}}$ ed., São Paulo, Atlas, 2009, pp. 31/33; Pedro Batista Martins, Anotações Sobre a Arbitragem no Brasil e o Projeto de lei do Senado 78/92, in Revista de Processo, vol. 77, janeiro de 1995, p. 25 e seguintes; Paulo Furtado, Juízo Arbitral, 2a ed., Salvador, Nova Alvorada, 1995, pp. 42/43; José Carlos de Magalhães, Arbitragem comercial (co-autoria com Luiz Olavo Baptista), Rio de Janeiro, Freitas Bastos, 1986, p. 72; Humberto Theodoro Junior, Arbitragem e terceiros - litisconsórcio fora do pacto arbitral - outras intervenções de terceiros, in Revista de Direito Bancário e do Mercado de Capitais, vol. 14, outubro de 2001, p. 357; Paulo Osternack Amaral, Vantagens, Desvantagens e peculiaridades da arbitragem envolvendo o Poder Público, in Arbitragem e Poder Público, São Paulo, Saraiva, 2010, p. 329. Ao lado dessa vertente, Rodolfo de Camargo Mancuso, A resolução dos conflitos e a função judicial no contemporâneo Estado de Direito, São Paulo, Revista dos Tribunais, 2009, p. 265, e Cândido Rangel Dinamarco, Instituições de Direito Processual Civil cit., vol. I, p. 142, afirmam que o juízo arbitral constitui uma expressão não estatal da jurisdição e por isso pode ser denominado como meio parajurisdicional de solução de controvérsias.

525 “O sentido contemporâneo de jurisdição já se desligou da acepção meramente semântica de 'declarar o direito', seja porque tal função não é mais exclusiva dos órgãos jurisdicionais, mas consente o concurso de outros agentes, órgãos e instâncias, seja porque o simples dizer o direito é muito pouco para que se tenha por atendido o poder-dever de composição justa, efetiva, tempestiva e duradoura do conflito, a que faz jus aquele cuja situação é tutelada pela ordem normativa ou ao menos é com ela compatível" (cf. A resolução dos conflitos e a função judicial no contemporâneo estado de direito (nota introdutória), Revista dos Tribunais, vol. 888 , outubro de 2009 , p. 9 e seguintes).

${ }^{526}$ Em julgamento de agravo regimental interposto em sede de homologação de sentença estrangeira (SE 5.206-7, Pleno, j. 12/12/2001), o STF declarou a constitucionalidade de vários dispositivos da Lei da Arbitragem, principalmente à luz da garantia da inafastabilidade da jurisdição.

527 "Art. $1^{\circ}$ As pessoas capazes de contratar poderão valer-se da arbitragem para dirimir litígios relativos a direitos patrimoniais disponíveis".

528 "Relativamente à primeira, o concurso do juízo estatal é necessário para a prática de determinado ato, por exemplo, para a anulação de um casamento. Ainda que, nesse caso, as partes estejam de acordo quanto à invalidação do vínculo matrimonial, essa providência deverá ser levada a efeito por intermédio de um juízo estatal. (...) No tocante à indisponibilidade propriamente do bem, no entanto, nem sempre será necessário o
} 
arbitrabilidade dos direitos naturalmente indisponíveis envolvendo o Poder Público, o autor propõe que "o diferencial quanto à possibilidade ou não de transação está ligada à afetação dos interesses envolvidos. Se afetados ou titularizados exclusivamente a sujeitos determinados, sem repercussões de caráter geral, como no caso de alimentos, a transação é admissível. Se contudo, a indisponibilidade envolver interesses gerais que, mesmo por via indireta transcenderem a uma sujeito determinado, como na interdição, inviável juridicamente a transação e presente a reserva de jurisdição" ${ }^{\text {, } 29}$.

Com outro enfoque, também em trabalho recente denominado Ordem Pública e Processo - O tratamento das questões de ordem pública no direito processual civil, Ricardo de Carvalho Aprigliano expôs que no universo dos direitos indisponíveis há componentes que se revelam disponíveis e que, portanto, admitem composição, transação e até renúncia; assim, no sempre lembrado exemplo do direito aos alimentos, o aspecto patrimonial escapa da indisponibilidade ${ }^{530}$.

No tocante aos direitos coletivos, a abertura para que sejam objeto de composição já vem com o art. $5^{\circ}, \S 6^{\circ}$, da Lei n. 7.347/85 (acrescido pelo CDC à Lei da Ação Civil Pública), que autoriza o estabelecimento de compromisso de ajustamento de conduta. Então, aproveitando as lições do Professor Carlos Alberto de Salles, para o caso dos direitos individuais homogêneos que são afetados a sujeitos determinados, a sua arbitrabilidade é inafastável ${ }^{531}$.

concurso da jurisdição estatal, pois há bens que, muito embora abrangidos por um regime legal de indisponibilidade, se submetem à transação das partes" (cf. Arbitragem em contratos administrativos, Rio de Janeiro, Forense, 2011, p. 94).

${ }_{529}$ Cf. Arbitragem em contratos administrativos cit., p. 95.

${ }^{530}$ Ordem Pública e Processo - o tratamento das questões de ordem pública no direito processual civil, São Paulo, Atlas, 2011, p. 18. Em sentido semelhante, recomendando a arbitragem e situações envolvendo interesse público: v. Eros Roberto Grau, Da arbitrabilidade de litígios envolvendo sociedades de economia mista e da interpretação de cláusula compromissória, in Revista de Direito Bancário e do Mercado de Capitais, vol. 18, outubro de 2002, p. 395 e seguintes.

${ }^{531}$ Com argumentos ligeiramente diversos - e mais ampliativos - já se pronunciou Ada Pellegrini Grinover na ocasião da Conferência sobre Arbitragem na Tutela dos Interesses Difusos e Coletivos realizada em 2006: "Já vimos que os interesses difusos, coletivos, stricto sensu e individuais homogêneos se colocam a meio caminho entre o interesse público e o interesse privado. Então se já no campo do direito público, stricto sensu, existe essa abertura para as vias alternativas de solução de controvérsias, com muito maior razão podemos aplicar essas vias alternativas à solução de conflitos metaindividuais, transindividuais, interesses difusos e coletivos, stricto sensu, e mais ainda, em relação aos interesses ou direitos individuais homogêneos, em que se trata, na verdade, de direitos subjetivos disponíveis, que só são veiculados, ou melhor, que podem ser veiculados, processualmente, por intermédio de um processo coletivo" (Revista de Processo, vol. 136, junho de 2006, p. 253). 
É certo que, na esfera privada, a escolha da arbitragem está condicionada à manifestação de vontade das partes, de acordo com a Lei 9.307/96. Aliás, é assente que a arbitragem tem suas raízes mais sólidas no princípio da autonomia da vontade.

Na situação específica do consumidor vulnerável, o CDC prevê que será abusiva a compulsoriedade da cláusula compromissória. Em complemento a isso, a Lei n. 9.307/96 estatui no art. $4^{\circ}, \S 2^{\circ}$, que: "Nos contratos de adesão, a cláusula compromissória só terá eficácia se o aderente tomar a iniciativa de instituir a arbitragem ou concordar, expressamente, com a sua instituição, desde que por escrito em documento anexo ou em negrito, com a assinatura ou visto especialmente para essa cláusula". Portanto, invariavelmente deverá ser escrita a opção pela arbitragem como meio de solução das controvérsias individualmente surgidas nas relações de consumo.

Mas a verdadeira dificuldade está em se implementar o juízo arbitral a partir das relações reguladas pelo Código do Consumidor que não surgem das práticas de consumo e que independem de relação contratual entre as partes - e, especialmente, quando tratadas na dimensão coletiva. Assim, na dicção dos arts. $2^{\circ}$, parágrafo único, e 17 do CDC, respectivamente, "a coletividade de pessoas, ainda que indetermináveis, que haja intervindo nas relações de consumo" bem como "as vítimas do evento" são equiparadas ao consumidor.

A Professora Ada Pellegrini Grinover já assinalou que "a única maneira (...), por enquanto (...) é pela intermediação do juiz. Então a arbitragem não seria propriamente um meio de evitar o processo, mas seria um meio de encurtá-lo",532. Nesse passo, proposta equivalente foi inserida no Código Modelo de Processos Coletivos para a Ibero-América 533 e no brasileiro Projeto de Lei de Ação Civil Pública ${ }^{534}$ (Projeto n. 5.139/2009).

Mas antes da judicialização do conflito, ainda nos ocorre a possibilidade de verdadeiras arbitragens em relações (de consumo ou não) que admitam um diálogo

\footnotetext{
${ }^{532}$ Cf. Conferência cit., p. 254.

533 “Art. 11. Audiência preliminar - Encerrada a fase postulatória, o juiz designará audiência preliminar, à qual comparecerão as partes ou seus procuradores habilitados a transigir. $§ 1^{\circ}$. O juiz ouvirá as partes sobre os motivos e fundamentos da demanda e tentará a conciliação, sem prejuízo de sugerir outras formas adequadas de solução de conflito, como a mediação, a arbitragem e a avaliação neutra de terceiro".

534 “Art. 19. Não sendo o caso de julgamento antecipado, encerrada a fase postulatória, o juiz designará audiência preliminar, à qual comparecerão as partes ou seus procuradores, habilitados a transigir. $\S 1^{\circ}$. O juiz ouvirá as partes sobre os motivos e fundamentos da demanda e tentará a conciliação, sem prejuízo de outras formas adequadas de solução do conflito, como a mediação, a arbitragem e a avaliação neutra de terceiro, observada a natureza disponível do direito em discussão”.
} 
eficiente entre demandante, demandado e árbitros, como medida inserida na Política Nacional das Relações de Consumo ${ }^{535}$.

Assim, por exemplo, na hipótese de dano moral causado supostamente em razão da veiculação de matéria jornalística em determinado site de internet, a popularidade e a fácil acessibilidade do veículo de comunicação poderiam ser aproveitadas para, a um só tempo, garantir a publicidade do processo arbitral, proporcionar aos membros do grupo suficiente comunicação da pendência e dos atos do processo arbitral, e ampliar numericamente os indivíduos aderentes tanto à arbitragem quanto à autoridade da sentença arbitral, fortalecendo o mecanismo como forma de prevenir conflitos.

Vale o registro da conhecida "arbitragem" disciplinada pela Lei Geral de Telecomunicações (art. 19, inciso XVII, da Lei 9.472/97), segundo a qual compete à ANATEL "compor administrativamente conflitos de interesses entre prestadoras de serviço de telecomunicações" - que podem ter amplo espectro em direitos individuais homogêneos. Mas é correta a advertência da doutrina ${ }^{536}$ no sentido de que essa atividade da ANATEL, de cunho administrativo, distancia-se da fórmula heterocompositiva (e jurisdicional) prevista na Lei n. 9.307/96.

Todavia, a menção traz a lembrança sobre a conveniência da arbitragem em causas envolvendo agências reguladoras e prestadoras de serviços de massa, como telefonia (ANATEL), plano de saúde (ANS), transmissão de energia elétrica (ANEEL), transporte terrestre (ANTT) e aviação civil (ANAC), em que a especialização dos árbitros - elemento não necessariamente presente no processo judicial - pode ser crucial para se alcançar a complexidade do litígio.

Enfim, encarado como um meio alternativo de acesso à justiça, a arbitragem, já se sabe, tem muito a contribuir para o aumento da confiança coletiva na jurisdição, seja ela estatal ou não.

\footnotetext{
${ }^{535}$ Neste ponto, vale a nota da opinião de André Medeiros Moraes no sentido de que a autorização para a arbitragem coletiva já aparece no atual art. 104 do CDC (Arbitragem nas ações de consumo, Curitiba, Juruá, 2006, pp. 221/222). As críticas desenvolvidas por Antonio Gidi à previsão expressa da arbitragem no direito brasileiro projetado, com base na experiência norte-americana, na verdade expõem as soluções para os supostos óbices: 'Se o juiz poderá 'sugerir' a arbitragem coletiva às 'partes', essa via certamente também poderá ser escolhida livremente pelas partes durante o processo coletivo. (...) Não está claro se essa 'escolha' também poderá ser feita em um contrato de adesão, como acontece nos Estados Unidos, mas isso será resolvido pelo direito substantivo a ser aplicado. É lícito também concluir que a coisa julgada do laudo arbitral coletivo se operará da mesma maneira que a da sentença coletiva (...)" (cf. Rumo a Código de Processo Civil Coletivo cit., p. 200).

${ }^{536}$ Pedro Batista Martins, Arbitragem e o setor de telecomunicações no Brasil, in Revista de Arbitragem e Mediação, vol. 9, abril de 2006, p. 260.
} 


\section{Transação}

Muito já se falou sobre a dissociação entre o titular do direito de ação e o titular do direito subjetivo transindividual. Chegou-se a mencionar também que, em situações ordinárias, não é dado ao legitimado extraordinário dispor do bem jurídico litigioso $^{537}$.

A problemática se traduzia na concepção tradicional de que, por mais que eles tivessem caráter patrimonial e disponível, "os atos que importarem, direta ou indiretamente, disposição do objeto material da controvérsia, como a transação e o reconhecimento do pedido, não estão abrangidos entre as faculdades próprias à substituição processual" ${ }^{538}$.

A ideia era ainda reforçada especialmente quando fosse nitidamente indisponível o bem jurídico tutelado pelo legitimado extraordinário - como o direito ao meio ambiente sadio, à inexistência de produtos nocivos ou de cláusulas abusivas nas relações de consumo e etc. -, pois, de acordo com as regras de direito civil, é vedada a transação, salvo sobre "direitos patrimoniais de caráter privado" (art. 841 do Código Civil).

Mas razões práticas demonstraram que a autocomposição não podia ser descartada. Fernando Grella Vieira apontou que: "a disposição do responsável pelo dano de se adequar às exigências da lei ou de satisfazer integralmente o dano acabava por atender, finalisticamente, aquilo que seria de se buscar ou já se estaria postulando na via judicial, por meio da ação civil pública" ${ }^{\text {539 }}$. Por isso, segundo o autor, manter vedada a transação atuava em desfavor dos direitos transindividuais.

De forma semelhante, Geisa de Assis Rodrigues também sustentou: “O que se revela extremamente vantajoso em relação à ação judicial é que o compromisso é menos burocrático e menos dispendioso, além do fato de que ainda não tendo sido formulada a demanda judicial há um ambiente mais propício para a solução negociada" ${ }^{\$ 40}$.

Essa abertura dogmática permitiu que, com a vigência do Código do Consumidor, fosse inserida na Lei n. 7.347/85, autorização literal para que os órgãos

\footnotetext{
${ }^{537}$ Vide nota 149.

${ }^{538}$ Cf. Estudo sobre a substituição processual no direito brasileiro cit., p. 30 e Zavascki, Ministério Público, ação civil pública e defesa de direitos individuais homogêneos, Revista Forense, vol. 333, ano 92, janeiro a março de 1996, p. 126.

${ }^{539}$ Cf. A transação na esfera da tutela dos interesses difusos e coletivos: compromisso de ajustamento de conduta, in Ação civil pública - Lei 7.347/1985 - 15 anos cit., pp. 267/268.

${ }^{540}$ Cf. Geisa de Assis Rodrigues, op. cit., p. 176.
} 
públicos legitimados às ações coletivas tomem dos interessados "compromisso de ajustamento de sua conduta às exigências legais, mediante cominações, que terá eficácia de título executivo extrajudicial" (art. $\left.5^{\circ}, \S 6^{\circ}\right)$.

A regra não exclui a possibilidade de composição em sede judicial, naturalmente. Mas em qualquer hipótese, não se restringe aos órgãos públicos a legitimidade para a representação da coletividade ${ }^{541}$, devendo ser estendida aos demais legitimados, desde que observados os requisitos da pertinência temática e da representatividade. Em consonância com o art. 92 do CDC, de se exigir a chancela obrigatória do Ministério Público ${ }^{542}$.

O objeto da transação, como se firmou, consiste no modo de ajustar a conduta do (suposto) réu ou, em outras palavras, regularizar a atividade violadora dos interesses coletivos. Assim, Daniel Fiuk leciona: "o objeto do ajustamento da conduta do fornecedor não são os direitos dos consumidores, esses verdadeiramente indisponíveis, mas as condições de modo, tempo e lugar do cumprimento das obrigações destinadas a reparar os danos causados. Essas obrigações possuem completo conteúdo patrimonial, uma vez que se destinam a reparar vícios ou fatos de produtos ou serviços. E, ainda que não tenham conteúdo patrimonial imediato - por exemplo, danos morais -, sua reparação será avaliada nesses termos"

Dessa forma, há quem entenda não se tratar de verdadeira transação ${ }^{544}$. Mas de outro lado, é inegável que o chamado Termo de Ajustamento de Conduta (TAC) encerra a controvérsia e previne novos litígios ${ }^{545}$.

\footnotetext{
${ }^{541}$ Fernando Grella Vieira, op. cit., p. 271, e Geisa de Assis Rodrigues, op. cit., p. 181. Em sentido contrário, Daniel Fink assevera que: "Ao se buscar o exato alcance da expressão órgãos públicos legitimados, deve-se entender que estamos diante da interpretação de uma exceção, e que, portanto, devemos utilizar critérios restritivos para se interpretar exceções. Esse critério restritivo exclui a possibilidade de se incluir, por extensão, entidades paraestatais, cuja composição não é completamente pública. Assim, somente o Ministério Público, a União, os Estados, os Municípios, o Distrito Federal e órgãos públicos podem celebrar termos de ajustamento de conduta" (cf. Alternativa à ação civil pública ambiental (reflexões sobre as vantagens do termo de ajustamento de conduta), in Ação civil pública - lei 7.347/1985 - 15 anos cit., pp. 128/129). Para Luis Roberto Proença, embora conveniente, seria de lege ferenda uma interpretação ampliativa dos legitimados a propor ajuste de conduta (Inquérito civil cit., p. 124).

${ }^{542}$ Fernando Grella Vieira, op. cit., p. 275.

${ }^{543}$ Cf. Daniel Roberto Fink, Código Brasileiro de Defesa do Consumidor comentado cit., 9a ed., pp. 996/997.

${ }^{544}$ Zavascki, Processo coletivo cit., p. 141; Marcelo Abelha Rodrigues e Rodrigo Klippel, A homologação judicial do TAC e a formação da coisa julgada coletiva em matéria ambiental, in O Novo Processo Civil Coletivo (coord. Guilherme José Purvin de Figueiredo e Marcelo Abelha Rodrigues), Rio de Janeiro, Lumen Juris, 2009, pp. 216/218; Mancuso, Ação civil pública cit., $12^{\mathrm{a}}$ ed., pp. 274/275; Leonel, Manual do processo coletivo cit., p. 349.

${ }^{545}$ Fernando Grella Vieira, op. cit., pp. 269/270; Didier e Zaneti, Curso cit., p. 322; Daniel Roberto Fink, Alternativa à ação civil pública ambiental cit., pp. 119/120.
} 
Assim, embora aparente que o ajuste da conduta do causador do dano se limite a obrigações da fazer ou não fazer, é lícita a disposição sobre medidas compensatórias ou reparatórias ${ }^{546}$.

No que diz respeito aos direitos individuais que possam sofrer com os reflexos do ajuste, interpretação sistêmica impõe a conclusão de que eles não serão prejudicados, salvo em caso de aquiescência ao compromisso ${ }^{547}$. Essa é uma das razões pelas quais os direitos individuais homogêneos respondem por um mínimo percentual de termos de ajustamento firmados na prática ${ }^{548}$.

Mas o futuro e breve aperfeiçoamento do microssistema de processos coletivos - notadamente no regime da coisa julgada envolvendo os direitos individuais homogêneos - podem nos conduzir ao encontro das conhecidas vantagens das soluções autocompositivas de litígios.

\footnotetext{
${ }^{546}$ Mas vale o alerta de Geisa de Assis Rodrigues, op. cit., p. 188: "Desde que o ajuste de conduta possa propiciar a mesma utilidade prática que o processo judicial poderia ter, a economia de tempo e dinheiro, além das vantagens educativas do processo de negociação, justificam essa situação excepcional. Essa opção deve ser realmente a última possibilidade, devido às dificuldade de se estabelecer o quantum adequado para reparar o dano".

${ }_{547}$ Em nossa opinião, diferentemente do TAC, a convenção coletiva de consumo (art. 107 do CDC) vincula obrigatoriamente os consumidores filiados às associações participantes na medida em que este último mecanismo se distancia da ideia de substituição processual e se aproxima da noção de representação.

${ }^{548}$ Paulo Cezar Pinheiro Carneiro apud Geisa de Assis Rodrigues, op. cit., p. 270.
} 


\section{PARTE IV - PROCESSO COLETIVO EM DEFESA DE INTERESSES INDIVIDUAIS HOMOGÊNEOS NA EXPERIÊNCIA ESTRANGEIRA}

\section{Europa}

\subsection{A preocupação da União Européia com a tutela dos consumidores}

No âmbito transnacional da União Europeia, os interesses transindividuais ganham tratamento setorial e restrito à tutela dos consumidores. Como descreve Sergio Chiarloni $^{549}$, trata-se de resultado da instituição do mercado comum entre os Estados membros, onde há livre trânsito de pessoas, bens, serviços e capitais.

Dentre os objetivos a serem perseguidos pela Comunidade Europeia, a partir de 1992 com a assinatura do Tratado de Maastricht, encontra-se a proteção dos consumidores. No entender de Jorge Miranda, a fórmula contida no tratado sobre as questões econômicas, políticas, culturais, de saúde pública e de proteção aos consumidores, se assemelham mais aos dizeres de uma Constituição do que de uma diretiva, embora a União Europeia esteja fundada no "princípio da subsidiariedade"

De todo modo, os atos normativos da União Europeia são programáticos e, justamente em função do princípio da subsidiariedade, eles deixam espaço para o trabalho legislativo dos Estados membros ${ }^{551}$.

Na disciplina específica voltada à proteção dos consumidores, a Diretiva $\mathrm{n}$. 13 de 1993 espera das autoridades judiciárias e dos órgãos administrativos dos Estadosmembros o estabelecimento de meios adequados e eficazes para pôr termo à aplicação de cláusulas abusivas nos contratos celebrados com os consumidores.

No relatório elaborado por Sergio Chiarloni, o autor observa que "a differenza di quanto vedremo con riferimento alla seconda direttiva, qui non si parla di interessi collettivi, malgrado che, ovviamente, non si possa non considerare un interesse

\footnotetext{
${ }^{549}$ Os processos coletivos nos países de civil law e common law cit., pp. 23/24.

${ }^{550}$ Cf. O Tratado de Maastricht e a Constituição Portuguesa, in Revista do Tribunal Regional Federal $1^{\mathrm{a}}$ Região, Brasília, v. 8, n. 3, julho a setembro de 1996, p. 19.

551 Sem prejuízo disso, cabe o comentário de Andreas J. Krell: "Muitas diretivas, contudo, possuem um detalhamento quase igual aos regulamentos. Quando um Estado-membro falha na transferência do conteúdo material de uma diretiva da EU para o direito nacional, determinados dispositivos que sejam suficientemente concretos podem ser diretamente aplicáveis, no sentido de que qualquer cidadão europeu seja capaz de reivindicar seus direitos em relação às autoridades nacionais" (cf. Ordem jurídica e meio ambiente na Alemanha e no Brasil: alguns aspectos comparativos, in Revista de Direito Ambiental, vol. 31, julho de 2003, p. 178; disponível em Revista dos Tribunais on line, acesso em 30/11/2011).
} 
collettivo dei consumatori la redazione di contratti per adesione privi di clausole abusive" ${ }^{\text {552 }}$. Contudo, para nós, a proteção ali desenhada tem autênticos contornos coletivos. Sinal disso é a regra que consta do item 2 do art. $7^{\circ}$ da diretiva: "Os meios a que se refere o n. 1 incluirão disposições que habilitem as pessoas ou organizações que, segundo a legislação nacional, têm um interesse legítimo na defesa do consumidor, a recorrer, segundo o direito nacional, aos tribunais ou aos órgãos administrativos competentes para decidir se determinadas cláusulas contratuais, redigidas com vista a uma utilização generalizada, têm não um carácter abusivo, e para aplicar os meios adequados e eficazes para pôr termo à utilização dessas cláusulas" ${ }^{\text {"553 }}$.

Nesse sentido, Remo Caponi assevera que o objetivo dessa modalidade de tutela ao consumidor é "o controle de legitimidade abstrato, o qual prescinde da verificação do emprego da cláusula nos contratos concretos" e proporcionar "uma hipótese de eficácia secundum eventum litis: as contrapartes contratuais do utilizador da cláusula abusiva, terceiros com relação à ação vitoriosa da associação, podem invocar em seu favor a eficácia da sentença de acolhimento" $" 554$.

Já a Diretiva n. 27 de 1998 estabeleceu como escopo expresso a proteção de interesses coletivos do consumidor ${ }^{555}$, em diversos segmentos das atividades econômicas, conferindo legitimidade a organismos públicos e a organizações privadas que tenham por finalidade a defesa dos consumidores (art. $3^{\circ},(a)$ e $(b)$ ). Mas a disciplina não foi além da Diretiva n. 13 de 1998, que já dispunha de um tipo de injuction ou ação coletiva inibitória $^{556}$.

\footnotetext{
${ }_{552}$ Op. cit., p. 25.

553 Fonte: <http://eur-lex.europa.eu/LexUriServ/LexUriServ.do?uri=OJ:L:1993:095:0029:0034:PT:PDF>; acesso em $10 / 12 / 2011$.

554 Cf. Modelo europeu de tutela coletiva no processo civil: comparação entre a experiência alemã e italiana, in Revista de Processo, vol. 200, outubro de 2011, p. 235 e seguintes; disponível em Revista dos Tribunais on line, acesso em 30/11/2011.

555 “(2) Considerando que os mecanismos vigentes a nível nacional e comunitário para assegurar o cumprimento das referidas directivas, nem sempre permitem que se ponha termo atempadamente às violações prejudiciais dos interesses colectivos dos consumidores; que por interesses colectivos se entende os interesses que não incluem a cumulação dos interesses dos indivíduos que tenham sido prejudicados por uma infracção; que tal não prejudica as acções intentadas por indivíduos que tenham sido prejudicados por uma infracção" (disponível em: <http://eur-lex.europa.eu/LexUriServ/LexUriServ.do?uri=OJ:L:1998:166:0051:0055:PT:PDF>; acesso em 10/12/2011).

${ }^{556}$ Vale a nota de que a tutela inibitória, no entender de Aluísio Gonçalves de Castro Mendes é um "mínimo indispensável" na defesa dos direitos dos consumidores (Ações coletivas cit., p. 173).
} 
O grande mérito da Diretiva 1998/27 foi estatuir um controle "comunitário" dos contratos envolvendo os consumidores, na medida em que o art. $4^{\text {o }}$, item $1^{557}$, autoriza às entidades nacionais a provocação das autoridades de qualquer Estado-membro em busca de fazer cessar a infração ao direito dos consumidores.

Também a mais recente Diretiva n. 22 de 2009, conforme observou a Professora Ada Pellegrini Grinover ${ }^{558}$, foi tímida e restrita às ações inibitórias embora pudesse ter avançado para o terreno das ações indenizatórias dos danos provocados.

Por isso é que, em nível transnacional na União Europeia, não existe tutela coletiva dos direitos individuais ${ }^{559}$, embora disso dependa uma harmoniosa proteção aos direitos dos consumidores em caso de lesão que supere as fronteiras nacionais ${ }^{560}$.

\subsection{Portugal e as ações populares}

Portugal se insere no rol de países que apresentam um completo (e complexo) sistema de proteção dos direitos coletivos.

A lei portuguesa da ação popular (Lei n. 83 de 1995) cuidou tanto da proteção aos interesses coletivos previstos no art. $52^{\circ}$ da Constituição da República (saúde pública, direito dos consumidores, qualidade de vida, preservação do ambiente e do patrimônio cultural, a defesa dos bens do Estado, das regiões autônomas e das autarquias), quanto dos individuais por danos causados em massa.

557 “Cada Estado-membro tomará as medidas necessárias para assegurar que, em caso de infração com origem nesse Estado-membro, qualquer entidade competente de outro Estado-membro em que os interesses por ela protegidos sejam afectados pela infração possa recorrer ao tribunal ou autoridade administrativa referidos no artigo $2^{\circ}$., mediante a apresentação da lista prevista no n. ${ }^{\circ} 3$ ".

${ }^{558}$ Parlamento Europeu e Conselho: Diretiva 2009/22 CE de 23.04.2009: as ações inibitórias de tutela do consumidor, in Revista de Processo, vol. 175, setembro de 2009, p. 230.

${ }_{559}$ Assim, v.: Giuseppe Tarzia, La tutela inibitoria contro le clausole vessatorie, in Revista de Processo, vol. 114, março de 2004, p. 131: "Il rimedio collettivo e quello individuale operano dunque su piani differenti e la diversità del thema decidendum, oltreché delle parti, impedisce anche di delineare un nesso di pregiudizialità - dipendenza fra l'azione inibitoria e l'azione individuale: un rimedio, il primo, preventivo dell'uso o dell'ulteriore uso di clausole abusive, autonomamente proponibile e munito di proprie sanzioni; un rimedio, il secondo, successivo e repressivo, che introduce un giudizio oggettivamente oltre che soggettivamente diverso".

${ }^{560}$ Como observado pela Comissão das Comunidades Europeias no famoso Livro Verde, "Estas diferentes soluções devem ser examinadas tendo em mente o principio de subsidiariedade, segundo o qual a Comunidade só intervém, nos domínios em que não existe competência comunitária exclusiva, se e na medida em que os objectivos da acção encarada não possam ser suficientemente realizados pelos Estadosmembros, e possam, pois, devido à dimensão ou aos efeitos da acção prevista, ser melhor alcançados ao nível comunitário (Tratado da União Europeia, artigo 3. ${ }^{\circ}$-B)" (cf. O acesso dos consumidores a justiça e a resolução dos litígios de consumo no Mercado Único, p. 84, 1993, disponível em: <http://eurlex.europa.eu/LexUriServ/LexUriServ.do?uri=COM:1993:0576:FIN:PT:PDF>; acesso em 10/12/2011). 
Como preceitua o art. $22^{\circ 561}$ da Lei 83/95, a ação popular poderá culminar na condenação do réu pelos danos causados, a ser individualizada no interesse dos lesados identificados, ou subsidiariamente revertida ao Ministério da Justiça que aplicará os recursos financeiros na promoção do acesso à justiça.

Em relação ao direito brasileiro, o diferencial da ação popular portuguesa na tutela coletiva dos interesses individuais reside nos elementos da legitimação e da coisa julgada.

Por regra constitucional expressa do art. $52^{\circ 562}$, é atribuída legitimidade aos membros isolados do grupo lesado, o que faz da ação portuguesa instrumento de participação popular, também quando voltada à defesa de interesses individuais homogêneos ${ }^{563}$.

Por outro lado, a iniciativa para a ação popular, no que diz respeito ao direito dos consumidores, é estendida pela Lei n. 24/96 aos órgãos estatais (Ministério Público e Instituto do Consumidor) e a entes privados (associações ou outros cidadãos).

Aliás, a Lei n. 24/96, que constituiu verdadeira Lei de Defesa do Consumidor (LDC), prestigiou a tutela coletiva dos direitos individuais dos consumidores com nítida inspiração no CDC brasileiro ${ }^{564}$, na medida em que faz menção em diversos dispositivos aos direitos individuais homogêneos.

Indo além da Lei n. 83/95, a Lei n. 24/96 previu também expressamente a ação inibitória em favor do consumidor ${ }^{565}$.

\footnotetext{
561 “1 - A responsabilidade por violação dolosa ou culposa dos interesses previstos no artigo 1. ${ }^{\circ}$ constitui o agente causador no dever de indemnizar o lesado ou lesados pelos danos causados. 2 - A indemnização pela violação de interesses de titulares não individualmente identificados é fixada globalmente. 3 - Os titulares de interesses identificados têm direito à correspondente indemnização nos termos gerais da responsabilidade civil. 4 - O direito à indemnização prescreve no prazo de três anos a contar do trânsito em julgado da sentença que o tiver reconhecido. 5 - Os montantes correspondentes a direitos prescritos serão entregues ao Ministério da Justiça, que os escriturará em conta especial e os afectará ao pagamento da procuradoria, nos termos do artigo $21 .^{\circ}$, e ao apoio no acesso ao direito e aos tribunais de titulares de direito de acção popular que justificadamente o requeiram".

562 "1. Todos os cidadãos têm o direito de apresentar, individual ou colectivamente, aos órgãos de soberania, aos órgãos de governo próprio das regiões autónomas ou a quaisquer autoridades petições, representações, reclamações ou queixas para defesa dos seus direitos, da Constituição, das leis ou do interesse geral e, bem assim, o direito de serem informados, em prazo razoável, sobre o resultado da respectiva apreciação".

${ }^{563}$ Assim, v.: Miguel Teixeira de Sousa, A tutela jurisdicional dos interesses difusos no direito português, in Revista de Processo, vol. 128, outubro de 2005, p. 91.

${ }^{564}$ Nessa linha, vide: Recurso e acórdão do Supremo Tribunal de Justiça de Portugal cit., p. 137, e Rodrigo Reis Mazzei, Tutela coletiva em Portugal: uma breve resenha, in Revista Jurídica do Ministério Público do Estado de Minas Gerais, Belo Horizonte, n. 7, julho a dezembro de 2006, pp. 81/82.

565 “Art. $10^{\circ}$. Direito à prevenção e acção inibitória. 1 - É assegurado o direito de acção inibitória destinada a prevenir, corrigir ou fazer cessar práticas lesivas dos direitos do consumidor consignados na presente lei, que,
} 
O outro diferencial da ação popular portuguesa repousa na aproximação com a class action for damages norte-americana, no que diz respeito à extensão erga omnes do julgado aos membros do grupo e ao direito de exclusão da ação representativa, conforme estabelecem os arts. $14^{\circ}$ e $15^{0566}$ da Lei n. 83/95.

Neste tema, Miguel Teixeira de Sousa já sustentou que a melhor solução para a realidade portuguesa seria a coisa julgada secundum eventum litis, assegurado o controle da representatividade adequada ${ }^{567}$. De seu turno, o autor Carlos Manuel Ferreira da Silva é da opinião de evitar "uma desconfortável, quiçá inconstitucional, diferenciação entre as posições de autor e réu no que concerne a esses efeitos" ${ }^{\text {} 568}$; por isso, defende a manutenção do regime de coisa julgada erga omnes atuando pro et contra.

Indo mais longe, José Lebre de Freitas repudia integralmente o regime da coisa julgada erga omnes, sustentando que: “nem a citação edital (sic), ou através dos meios de comunicação social, poderá constituir presunção inilidível do conhecimento da acção por todos os interessados nem a flutuação da titularidade do interesse difuso, e mesmo do interesse colectivo, e portanto da própria existência ou do grau da sua violação, se coaduna com a idéia da perda do direito processual de o fazer valer, por via dum comportamento omissivo. O conceito de representação, que pressupõe uma procuração ou um mandato, não pode servir de álibi a esta violação" ${ }^{\text {"569 }}$.

nomeadamente: a) Atentem contra a sua saúde e segurança física; b) Se traduzam no uso de cláusulas gerais proibidas; c) Consistam em práticas comerciais expressamente proibidas por lei. 2 - A sentença proferida em acção inibitória pode ser acompanhada de sanção pecuniária compulsória, prevista no artigo $829 .^{\circ}$-A do Código Civil, sem prejuízo da indemnização a que houver lugar".

566 “Artigo 14. ${ }^{\circ}$ Regime especial de representação processual. Nos processos de acção popular, o autor representa por iniciativa própria, com dispensa de mandato ou autorização expressa, todos os demais titulares dos direitos ou interesses em causa que não tenham exercido o direito de auto-exclusão previsto no artigo seguinte, com as consequências constantes da presente lei. Artigo 15. ${ }^{\circ}$ Direito de exclusão por parte de titulares dos interesses em causa. 1 - Recebida petição de acção popular, serão citados os titulares dos interesses em causa na acção de que se trate, e não intervenientes nela, para o efeito de, no prazo fixado pelo juiz, passarem a intervir no processo a título principal, querendo, aceitando-o na fase em que se encontrar, e para declararem nos autos se aceitam ou não ser representados pelo autor ou se, pelo contrário, se excluem dessa representação, nomeadamente para o efeito de lhes não serem aplicáveis as decisões proferidas, sob pena de a sua passividade valer como aceitação, sem prejuízo do disposto no n. ${ }^{4}$ ".

567 "Especificamente quanto ao âmbito subjectivo do caso julgado da decisão proferida num processo em que se tutelam interesses difusos, a melhor solução parece ser a de estender os efeitos do caso julgado a terceiros que, não tendo sido autores na acção, deles possam beneficiar. É certo que isso origina uma eficácia subjectiva do caso julgado definida secundum eventum litis" (cf. Legitimidade processual e ação popular no direito do ambiente cit., p. 127).

${ }_{568}$ Os processos coletivos nos países de civil law e common law cit., p. 49.

${ }^{569}$ Cf. A acção popular ao serviço do ambiente, in Revista de Direito Ambiental, vol. 1, janeiro de 1996, p. 36 e seguintes. 
No plano coletivo, a lei portuguesa volta a ter ponto de contato com o CDC brasileiro e abriga a coisa julgada secundum eventum probationis, a teor do art. $19^{\circ}$ da Lei $83 / 95^{570}$.

Em suma, com ligeiro atraso na codificação do direito dos consumidores, Portugal adotou alguns mandamentos que já norteiam a legislação brasileira. Mas, consciente de que não é saudável uma transposição cega dos institutos processuais estrangeiros, o legislador português não se rendeu absolutamente ao modelo do CDC e também buscou proveitosa inspiração na common law norte-americana.

\subsection{Itália e as ações coletivas para a tutela dos consumidores}

Ao examinar a receptividade do sistema italiano às diretivas comunitárias sobre a tutela aos consumidores, Ecio Perin Junior $^{571}$ enfatizou que a Itália foi mais resistente ao movimento consumerista que já se alastrava há décadas nos países da Europa. As razões, segundo o autor, são culturais, econômicas e políticas, impostas pela realidade do pós-guerra (atraso no desenvolvimento econômico, monopólio da iniciativa dos partidos políticos de massa e falta de cultura dos direitos dos consumidores).

Antes disso, porém, a Itália já se notabilizada por regras setoriais de tutela coletiva aos trabalhadores e ao meio ambiente. Segundo Andrea Giussani ${ }^{572}$, algumas regras remetem ao ano de 1890 , além da tradição da actio popularis herdada do direito romano. Mas tais instrumentos processuais sempre foram confrontados pela clássica e arraigada vedação à extensão ultra partes da eficácia da sentença.

Mas, a despeito de terem surgido na Itália os intensos debates sobre a tutela dos interesses transindividuais da década de 1970, o associativismo consumerista só foi incentivado em 1998. Com base nas diretivas da União Europeia, a Lei n. 281 permitiu às associações de consumidores a propositura de ações inibitórias visando o resguardo de direitos coletivos de consumo descrito do parágrafo segundo do art. $1^{0573}$.

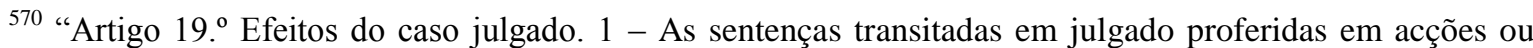
recursos administrativos ou em acções cíveis, salvo quando julgadas improcedentes por insuficiência de provas, ou quando o julgador deva decidir por forma diversa fundado em motivações próprias do caso concreto, têm eficácia geral, não abrangendo, contudo, os titulares dos direitos ou interesses que tiverem exercido o direito de se auto-excluírem da representação".

${ }^{571}$ Aspectos relevantes da tutela coletiva do consumidor no direito italiano em face do direito comunitário europeu, in Revista de Direito do Consumidor, vol. 38, abril de 2001, pp. 25 e seguintes.

572 Os processos coletivos nos países de civil law e common law cit., p. 165.

573 " 2 . Ai consumatori ed agli utenti sono riconosciuti come fondamentali i diritti: a) alla tutela della salute; b) alla sicurezza e alla qualità dei prodotti e dei servizi; c) ad una adeguata informazione e ad una corretta
} 
De acordo com a Lei n. 281/1998, a representatividade das associações de consumo é controlada por um juízo administrativo prévio à propositura da ação, pelo Ministério da Indústria, Comércio e Artesanato.

$\mathrm{Na}$ forma do parágrafo $7^{\circ}$, do art. $3^{\mathrm{o}} 574$, a lei não excluiu a possibilidade de serem ajuizadas ações individuais mas, a respeito da relação entre as ações associativas e as pretensões individuais, a regra pouco esclareceu. Quando menciona a reunião de procedimentos, a lei não diz se é providência facultativa ou obrigatória, nem propõe um modo de comunicação da existência da ação coletiva a fỉm de incentivar a adesão dos consumidores.

Por ser exclusivamente inibitória, e não condenatória, eram minimizados o âmbito de aplicação e o proveito econômico da iniciativa das associações, o que não contribuía para o seu fortalecimento. Esse panorama, portanto, afastava a ação coletiva de defesa dos consumidores do bem sucedido modelo da class action ${ }^{575}$.

O aperfeiçoamento do sistema italiano de tutela coletiva dos direitos dos consumidores veio a ocorrer em 2008, com a inserção do art. 140-bis no Codice del Consumo (codificação esta datada de 2005), que previu a azione collettiva risarcitoria.

A previsão da azione collettiva risarcitoria produziu um salto evolutivo relevante no ordenamento italiano. Ficou expresso que: (i) é optativa a adesão do consumidor (opt in) à ação coletiva movida por associação ou comitê de consumo; (ii) o ajuizamento da ação coletiva interrompe a prescrição das pretensões individuais; (iii) semelhantemente à class certification, há um pronunciamento judicial prévio sobre a admissibilidade da ação coletiva; (iv) a existência da ação coletiva deverá ter idônea

pubblicità; d) all'educazione al consumo; e) alla correttezza, trasparenza ed equità nei rapporti contrattuali concernenti beni e servizi; f) alla promozione e allo sviluppo dell'associazionismo libero, volontario e democratico tra i consumatori e gli utenti; g) all'erogazione di servizi pubblici secondo standard di qualità e di efficienza".

574 "Fatte salve le norme sulla litispendenza, sulla continenza, sulla connessione e sulla riunione dei procedimenti, le disposizioni di cui al presente articolo non precludono il diritto ad azioni individuali dei consumatori che siano danneggiati dalle medesime violazioni".

575 Andrea Giussani descreveu as muitas diferenças, e as conseqüentes desvantagens, da ação coletiva italiana em comparação a class action: "[dal]la mancanza, di fondamentale rilievo pratico, di efficaci incentivi economici all'esperimento di azioni collettive fondate: nessun significativo incremento degli onorari di difesa posti a carico del convenuto soccombente era previsto per l'ipotesi di accoglimento della domanda diretta a far valere situazioni soggettive di portata superindividuale, e la associazione non poteva nemmeno (salvo che nell'ipotesi da ultimo indicata) percepire quelle somme che la controparte può essere condannata a pagare in casu di inottemperanza al provvedimento di tutela dell'interesse collettivo (...). Inoltre, non era previsto alcun meccanismo diretto a prevenire i comportamenti collusivi ai danni della categoria di riferimento: rinunce e transazioni non richiedevano alcuna omologazione giudiziale" (Os processos coletivos nos países de civil law e common law cit., p. 168). 
publicidade; e (v) a coisa julgada, favorável ou não, vincula os consumidores que tenham aderido ou intervindo na ação coletiva.

Em 2009, em virtude da Lei n. 99/2009, o art. 140-bis foi aperfeiçoado e passou a disciplinar a azione di classe, para tutela dos diritti individuali omogenei dei consumatori e degli utenti, a ser movida tanto por associação ou comitê de consumo, quanto pelo consumidor singular.

A nova lei também cuidou da distribuição de competência, determinando que é competente o tribunal da capital da região em que a empresa ré tem sede, e previu que as despesas para comunicação dos membros do grupo recaem sobre a parte sucumbente.

Outrossim, houve salutar preocupação do legislador italiano em prever literalmente a possibilidade de transação e renúncia, cujos efeitos não interferem nas pretensões individuais dos consumidores que com ela não tenham consentido.

De contribuição, a experiência italiana na tutela dos direitos individuais homogêneos, inaugurada em 2008, espelha um avanço legislativo mais acelerado do que o direito brasileiro. Verdade que as diretivas comunitárias são um catalisador, mas não menos verdade é que houve pouca - ou nenhuma - relutância parlamentar e governamental na Itália no sentido de incrementar radicalmente as azione di classe. Essa resistência, infelizmente, ainda se apresenta no Brasil, a exemplo da rejeição pela Câmara dos Deputados do Projeto de Lei n. 5.139/2009. 


\section{Estados Unidos da América e as class actions for damages}

O antecedente histórico mais próximo das ações coletivas brasileiras para a defesa dos direitos individuais homogêneos é a class action for damages dos Estados Unidos.

Trata-se de um paradigma que inspira, e ainda intriga, juristas estrangeiros. Seu mérito se deve à formulação de um instrumento processual sintonizado com fatores sociais, culturais e econômicos da sociedade norte-americana. Assim é que a class action for damages atinge um grau de eficiência invejável.

Para uma breve narração histórica, foram motivos de ordem prática que levaram a Suprema Corte a editar, em 1842, a Equity Rule 48. A justificativa dada pela Suprema Corte pode ser assim reproduzida: "Where the parties interested in the suit are numerous, their rights and liabilities are so subject to change and fluctuation by death or otherwise, that it would not be possible, without very great inconvenience, to make all of them parties, and would oftentimes prevent the prosecution of the suit to a hearing. For convenience, therefore, and to prevent a failure of justice, a court of equity permits a portion of the parties in interest to represent the entire body, and the decree binds all of them the same as if all were before the court. The legal and equitable rights and liabilities of all being before the court by representation, and especially where the subject-matter of the suit is common to all, there can be very little danger but that the interest of all will be properly protected and maintained"

Em 1912, a Equity Rule 48 foi reescrita e transformada na Equity Rule 38. Em 1938, a Suprema Corte então editou as Federal Rules of Civil Procedure, dentre as quais a Rule 23 é a que disciplina a class action. $\mathrm{O}$ atual regime das class actions for damages está centrado na reforma de $1966^{577}$, que resolveu muitas das imperfeições da Rule 23 na redação original de $1938^{578}$.

De essencial, a class action simboliza uma modalidade de representative action, com rigoroso controle de qualidade sobre a atuação do representante, que pode ser

\footnotetext{
${ }^{576}$ Fonte: <http://www.law.cornell.edu/wex/class_action>, acesso em 20/12/2011.

${ }^{577}$ Fonte: <http://www.uscourts.gov/uscourts/RulesAndPolicies/rules/2010\%20Rules/Civil\%20Procedure.pdf>; acesso em 20/12/2011.

${ }^{578}$ Como descreve Antonio Gidi, “A Rule 23, em sua versão original de 1938, nasceu destinada ao insucesso. A sua redação era confusa, complexa e demasiadamente abstrata, em total dessintonia com a realidade prática e a cultura jurídica americana moderna, principalmente no que se refere às hipóteses de cabimento. Ademais, a norma era incompleta, pois não previa medidas procedimentais que assegurassem os direitos dos membros ausentes e o respeito ao devido processo legal" (cf. A class action como instrumento cit., p. 55).
} 
qualquer membro do grupo. Aliás, o sucesso da class action repousa no tripé adequacy of representation, fair notice e rigth to opt-out.

Além da adequacy of representation, são pré-requisitos para que a class action receba a certification (e possa prosseguir como ação coletiva): numerosity (impraticabilidade do litisconsórcio), commonality (questão comum) e typicality (identidade entre as questões afetas ao representante e aos demais membros do grupo).

No tocante ao cabimento da class action for damages, como já se mencionou, a Regra 23 estatui que devem predominar as questões comuns sobre aquelas afetas à individualidade dos membros do grupo (predominance). Em adição, pressupõe-se que a class action seja o método mais justo e eficiente para a solução das questões comuns (superiority).

Sabendo que a class action, por ser uma representative action, produzirá efeitos sobre todos os membros do grupo (binding effects), foi preciso forjar um mecanismo que assegurasse a defesa dos interesses dos membros representados e ausentes (em respeito à garantia do due process of law) e propiciasse uma ampla divulgação da class action. Para isso, exige-se a notificação dos membros do grupo, com os melhores esforços de acordo com as circunstâncias do caso, a fim de que os interessados possam exercer o direito de exclusão (opt out) dos efeitos da class action.

A eficiência da notificação é resultado, na prática, da aliança formada entre o representante do grupo e o advogado, com vistas ao significativo montante em dinheiro (attorney's fees) que podem reverter ao causídico. Nesse cenário, o advogado custeia as pesadas despesas da class action, mas, de outro lado, aposta na vitória que pode lhe proporcionar abundantes honorários (com base no sistema de contingency fee).

Como se vê, muitos dos temas em torno da class action for damages exprimem preocupações universais de devido processo legal e de eficiência na resolução dos conflitos de massa. Mas, nunca é demais enfatizar: na importação dos seus institutos, não podem ser ignorados os caracteres peculiares da comunidade jurídica destinatária, e nem convém isolar os elementos que dão sustentação à class action (adequacy of representation, fair notice e right to opt out). 


\section{Ibero-América}

\subsection{Colômbia e as ações de grupo}

Na Colômbia, desde o Decreto 3.466/82, já se conhecia uma espécie de ação coletiva, movida por ligas de consumidores, cuja sentença favorável beneficiava, não só as partes, mas também os terceiros ausentes ${ }^{579}$.

A Constituição Política de 1991, em seu art. $88^{580}$, por seu turno, tratou de duas modalidades de ação coletiva: a ação popular e a ação que veicule interesse de um número plural de pessoas.

Não fosse a parte final do segundo parágrafo ("sin perjuicio de las correspondientes acciones particulares"), poderia ser prejudicado o alcance da regra constitucional, na medida em que as ações originadas de danos causados a um número plural de pessoas não diferem das ações populares. Assim, se o intuito do constituinte era introduzir no ordenamento colombiano a tutela coletiva dos interesses individuais, a norma constitucional pecou de início.

Tardou um pouco, mas em 1998 foi editada a Lei n. 472 que finalmente definiu o âmbito de aplicação das ações populares e das assim batizadas ações de grupo: “interpostas por um número plural ou um conjunto de pessoas que reúnem condições uniformes a respeito de uma mesma causa que originou prejuízos individuais para referidas pessoas. As condições uniformes devem ter também lugar a respeito de todos os elementos que configuram a responsabilidade. A ação de grupo se exercerá exclusivamente para obter o reconhecimento e pagamento de indenização pelos prejuízos" (tradução livre do art. $3^{\circ}$ da Lei 472/98).

Por técnica legislativa imprópria, a definição é repetida integralmente no art. 46 da Lei n. 472/98, o qual se propõe a regular a procedência das ações de grupo, com a adição de que o seu cabimento depende da formação de um grupo de pelo menos 20 pessoas.

579 Gabriel A. Stiglitz, Las acciones colectivas en proteccion del consumidor, in Revista de Direito do Consumidor, vol. 15, julho de 1995, p. 24.

580 "La ley regulará las acciones populares para la protección de los derechos e intereses colectivos, relacionados con el patrimonio, el espacio, la seguridad y la salubridad públicos, la moral administrativa, el ambiente, la libre competencia económica y otros de similar naturaleza que se definen en ella.

También regulará las acciones originadas en los daños ocasionados a un número plural de personas, sin perjuicio de las correspondientes acciones particulares.

Así mismo, definirá los casos de responsabilidad civil objetiva por el daño inferido a los derechos e intereses colectivos". 
Além da imperfeita redação do texto constitucional do art. 88, o legislador de 1998 parece que também se equivocou ao procurar teorizar sobre as ações de grupo. Quando descreve que elas são ajuizadas por um número plural ou um conjunto de pessoas, com base em condições uniformes, a hipótese se encaixa mais no cúmulo objetivo e subjetivo de ações, isto é, do litisconsórcio facultativo por afinidade de questões, o que não retrata uma verdadeira ação coletiva. Aliás, até aí, a lei não teria inovado ${ }^{581}$.

Já a parte final do art. $3^{\circ}$ retrata a vedação a provimentos não condenatórios, o que se distancia da tendência de universalizar a tutela dos direitos transindividuais.

No art. 48, o legislador infraconstitucional opta por obstar a iniciativa de entes governamentais, atribuindo legitimidade para as ações de grupo somente às pessoas físicas ou jurídicas que tenham sofrido um prejuízo individual com o ato danoso. $\mathrm{Na}$ doutrina colombiana ${ }^{582}$, já é defendida a ampliação desse rol.

\section{O Defensor del Pueblo, os Personeros Municipales e Personeros Distritales} (figuras análogas aos membros da Defensoria e do Ministério Público brasileiro, respectivamente), por seu turno, podem se ocupar da defesa de qualquer pessoa necessitada (“en situación de desamparo o indefensión”), mas a sua atuação parece ser subsidiária, já que a lei dispõe que figurarão como parte no processo judicial junto com os agraviados (queixosos ou vítimas). Mais do que isso, a necessidade de sua presença pode até ser discutível, já que no parágrafo único do art. $48^{583}$, está clara a adoção do modelo de representatividade dos ausentes.

Em ponto sobre o qual o legislador colombiano pôde acompanhar a fase evolutiva dos meios de comunicação de seu tempo, foi feliz a previsão do art. 53 no sentido de que o processamento da demanda será objeto de divulgação massiva e eficaz. Por conseqüência, no art. 56, intitulado "exclusión del grupo", optou-se de forma coerente pela faculdade de o indivíduo excluir-se do grupo e das conseqüências da ação coletiva (opt out).

\footnotetext{
581 O art. 50 do Código di Procedimiento Civil colombiano estabelece: "Litisconsortes facultativos. Salvo disposición en contrario, los litisconsortes facultativos serán considerados en sus relaciones con la contraparte, como litigantes separados. Los actos de cada uno de ellos no redundarán en provecho ni en perjuicio de los otros, sin que por ello se afecte la unidad del proceso".

${ }_{582}$ Ramiro Bejarano Guzmán, La tutela de los derechos difusos, colectivos e individuales cit., p. 471.

583 "Parágrafo. En la acción de grupo el actor o quien actúe como demandante, representa a las demás personas que hayan sido afectadas individualmente por los hechos vulnerantes, sin necesidad de que cada uno de los interesados ejerza por separado su propia acción, ni haya otorgado poder".
} 
E o modo de se efetuar o opt out seguiu o modelo das class actions norteamericanas: manifestação expressa do interessado em 5 dias da comunicação da demanda ou se demonstrado posteriormente que a defesa desenvolvida pelo representante do grupo não foi adequada. Isso já adianta outra regra das ações de grupo no direito colombiano: a sentença atua pro et contra na esfera individual dos membros da coletividade, ideia completada pelo art. $66^{584}$ da Lei n. 472/98.

Naturalmente, também há previsão de uma ampla divulgação da sentença coletiva. E nesse passo, a lei colombiana é curiosamente restritiva. O item 4 do art. 65 estabelece que há uma única publicação do extrato da sentença em jornal de grande circulação nacional (e isso independentemente da dimensão do dano); ainda, os interessados na liquidação devem se apresentar dentro de 20 dias, prazo este que aparentemente substitui qualquer outro prazo prescricional fixado em lei própria.

Por outro lado, relativamente ao Brasil, a Colômbia se adiantou na formação de um banco de dados que reúna a lista de todas as ações coletivas em curso naquele país $^{585}$, providência que, além de acentuar a eficiência do sistema, é inerente ao opt out, como já se explicou no decorrer do trabalho.

No que se refere à indenização, a lei parece se afastar da noção de condenação genérica pelos danos provocados, quando, no art. 55 estatui que novos membros poderão integrar o grupo, posteriormente à sentença, mas não haverá incremento no montante da indenização por ela estimada.

A título conclusivo, na nossa avaliação, a lei colombiana é ousada no tratamento coletivo dos direitos individuais e, em alguns pontos, deve ser aplaudida. Mas, por outro lado, não primou pela técnica e ainda resiste à sistematização mais precisa sugerida no Código Modelo ${ }^{586}$.

\footnotetext{
584 “Efectos de la sentencia. La sentencia tendrá efectos de cosa juzgada en relación con quienes fueron parte del proceso y de las personas que, perteneciendo al grupo interesado no manifestaron oportuna y expresamente su decisión de excluirse del grupo y de las resultas del proceso".

${ }_{585}$ Assim, Ramiro Bejarano Guzmán afirmou em 2003: "Entre los puntos que en Colombia han resultado positivos, está por ejemplo, la creación de un registro público de cobertura nacional de acciones populares y de grupo, que permita al ciudadano y a todas las autoridades no sólo establecer que procesos están en curso, sino cuáles han sido ya decididos. Eso además facilitará la centralización y consecución de la jurisprudencia de los jueces y tribunales, como también constatar los problemas vinculados a si ha operado el fenómeno de la cosa juzgada" (op. cit., p. 475).

${ }^{586}$ V. Ramiro Bejarano Guzmán, op. cit., pp. 468/475.
} 


\subsection{Província de Rio Negro (Argentina) e as ações coletivas}

A Constituição Argentina estatui a proteção aos direitos dos consumidores $\left(\operatorname{art.} 42^{587}\right)$ e relega às autoridades locais a competência para dispor sobre procedimentos de prevenção e solução dos conflitos.

Além das Províncias de Catamarca, Tierra del Fuego, Antártida e Islas de Atlântico Sur, de Santa Fé e de La Pampa ${ }^{588}$, que predicou a ação de amparo para a defesa de direitos difusos e coletivos, a Província de Rio Negro se destaca pela previsão de um verdadeiro processo coletivo de tutela a titulares de direitos individuais (Ley $\mathrm{n}$. 4142/2006).

A Ley n. $4141 / 2006^{589}$ consistiu em um novo Código Procesal Civil y Comercial da Província de Rio Negro. Mas, mesmo sendo um regulamento geral, introduziu nos arts. 688-bis, ter, quater e quinquies, regras exemplares de tutela coletiva de direitos individuais, com inspiração no Código Modelo de Processos Coletivos para a Ibero-América.

A outorga de legitimidade foi ampla - e aplaudida pela doutrina nacional ${ }^{590}$ -, pelo art. 688-bis, a: "los afectados, la Fiscalía de Estado, el ministerio público, los municipios y comunas, las entidades legalmente constituidas para la defensa de derechos colectivos y cualquier persona física que actúe en resguardo de los derechos afectados".

A semelhança do Projeto brasileiro n. 5.139/2009, o art. 688-quater autorizou a citação dos titulares dos interesses individuais, por iniciativa do réu, para uma obrigatória intervenção no processo coletivo: "El demandado también podrá citar al juicio a los titulares de los derechos individuales homogéneos a fin de que la sentencia les pueda ser opuesta".

\footnotetext{
587 "Los consumidores y usuarios de bienes y servicios tienen derecho, en la relación de consumo, a la protección de su salud, seguridad e intereses económicos; a una información adecuada y veraz; a la libertad de elección, y a condiciones de trato equitativo y digno. Las autoridades proveerán a la protección de esos derechos, a la educación para el consumo, a la defensa de la competencia contra toda forma de distorsión de los mercados, al control de los monopolios naturales y legales, al de la calidad y eficiencia de los servicios públicos, y a la constitución de asociaciones de consumidores y de usuarios. La legislación establecerá procedimientos eficaces para la prevención y solución de conflictos, y los marcos regulatorios de los servicios públicos de competencia nacional, previendo la necesaria participación de las asociaciones de consumidores y usuarios y de las provincias interesadas, en los organismos de control".

${ }^{588}$ Para referência da legislação dessas províncias, vide Aluísio Mendes, Ações coletivas cit., pp. 163/165.

589 Fonte: <http://www.legisrn.gov.ar/LEGISCON/despliego.php?campo=APROBADO\&clave=28159\&a=1\$LgcpDr28XyI>; acesso em $5 / 12 / 2011$.

590 Patricia Bermejo, La tutela de los derechos difusos, colectivos e individuales homogéneos - hacia um Código Modelo para Iberoamerica cit., p. 494.
} 
O alcance da coisa julgada também foi espelhado no modelo brasileiro (secundum eventum litis), na medida em que o art. 688-quinquies assegura ao titular do direito individual, não interveniente no processo coletivo, que se beneficie da coisa julgada coletiva, sem com ela se prejudicar: "La cosa juzgada recaída en el juicio puede ser invocada por terceros que no han intervenido en el proceso, contra quienes hayan intervenido, pero no puede serles opuesta".

Conforme explica Ada Pellegrini Grinover ${ }^{591}$, as normas especiais são enxutas mas integradas pelas regras do processo de amparo. Todavia, Francisco Verbic acentua que a inexistência de um sistema processual coletivo na Argentina ainda causa problemas práticos.

O autor enumera: "necesaria adaptación del mecanismo de debate a la complejidad del conflicto, las cuestiones de competencia, la litispendencia (tanto entre procesos colectivos como entre procesos individuales y colectivos), la flexibilización de las reglas sobre intervención de terceros, el derecho de autoexclusión de quienes no desean involucrarse en el resultado del pleito, la posibilidad de ampliar la discusión a través de audiencias públicas y de la intervención de amicus curiae, los dispositivos de control y las condiciones de validez de los acuerdos transaccionales, la publicidad del proceso y lo mecanismos de implementación de la sentencia ambiental"

\footnotetext{
${ }^{591}$ Os processos coletivos nos países de civil law e common law cit., p. 87.

592 Cf. El proyecto de reformas a la Ley General del Ambiente 25.675 - en búsqueda de un sistema procesal colectivo para la reparación del daño ambiental en la República Argentina, in Revista de Processo, vol. 157, março de 2009, p. 159.
} 


\section{PARTE V - OBSERVAÇÕES CRÍTICAS E CONCLUSÕES}

O escopo deste trabalho, como definido na introdução, é examinar o processo coletivo destinado à defesa dos direitos individuais homogêneos e os meios paralelos de tutela aos titulares de relações de massa.

Para tanto, foi descrito o momento histórico no qual se insere a tutela dos interesses transindividuais e, precisamente a tutela coletiva dos direitos individuais, estabelecendo a conexão entre a sociedade pós-industrializada, a massificação das relações intersubjetivas e a busca da ciência processual por eficiência. Também descrevemos a evolução legislativa no tocante à tutela coletiva no direito brasileiro.

Valendo-nos do desenvolvimento teórico em torno das categorias de direitos transindividuais, buscamos identificar o objeto de estudo, alcançando então a natureza, características e dimensões dos chamados interesses individuais homogêneos.

Então, como proposto inicialmente, sob uma ótica orgânica, foram debatidos os temas centrais que envolvem esse modelo de processo coletivo, à luz das normas constitucionais, das Leis n. 4.717/65, 7.347/85 e 8.078/90, que reunidas compõem o microssistema processual coletivo, e do direito projetado (Projeto n. 5139/2009) e comparado (Código Modelo de Processos Coletivos para a Ibero-América e outras experiências estrangeiras).

No tema da legitimidade, estudamos a classificação quase universalmente aceita na doutrina nacional, trazendo-a para o contexto dos processos coletivos. Ressalvada a observação de uma parcela significativa da doutrina (a qual preconiza a legitimação ordinária das associações que incluam em seus objetivos sociais a defesa de dado interesse coletivo), concluímos que, invariavelmente, em tema de direitos transindividuais (não dedutíveis via ação popular), há substituição processual e, portanto, legitimação extraordinária.

Ao tecer nossas considerações a respeito do rol de legitimados para a ação coletiva versando interesses individuais, abordamos a negativa de legitimidade ao membro isolado do grupo. Nesse ponto, procuramos não nos render às convidativas teses de ampliação máxima do acesso à justiça e aproximação do modelo da ação popular. Sustentamos que o fundamento de democracia participativa não é o fim imediato da tutela coletiva dos direitos individuais homogêneos e, então, a abertura para iniciativa dos 
cidadãos singulares (ou membros do grupo) não pode ser desacompanhada - como sucede na ação popular - de um controle de representatividade adequada.

Expusemos também a preocupação com os limites da atuação da Defensoria Pública. Buscamos demonstrar que, enquanto os carentes organizacionais podem ser defendidos pelo órgão, a carência organizacional fundada exclusivamente em razões econômicas dissociadas de critérios aceitáveis de aferição da pobreza, desautoriza a iniciativa da Defensoria Pública por lhe faltar pertinência temática.

Em relação à legitimação do Ministério Público, centramos a crítica à barreira não raro oposta à defesa de direitos individuais homogêneos, porque disponíveis. Destacamos principalmente o equívoco em se aferir a legitimidade do órgão a partir da disponibilidade do direito e não da relevância social inerente à tutela coletiva dos direitos individuais homogêneos ligados a assuntos de especial importância constitucional (como as relações tributárias, por exemplo).

Ainda em tema de legitimação, defendemos que é injusta a descrença no engajamento das associações brasileiras em ações coletivas. Na medida em que a sociedade civil é fortalecida na medida em que municiada de mecanismos processuais eficientes (somente outorgados pelo Código do Consumidor de 1990), a atuação das associações no Judiciário nacional não é tão longeva e tende a se consolidar.

Além disso, a iniciativa da sociedade civil organizada tem vantagens que superam as ações estatais. Isso porque os objetivos definidos pelas associações em defesa de interesses transindividuais tendem a ser mais alinhados (precisão) e contemporâneos (imediatismo) aos anseios da coletividade.

$\mathrm{Na}$ sequência, enfatizamos a importância do controle judicial da representatividade adequada do autor coletivo, como medida que se amolda à cláusula constitucional do due process of law. A ideia é principalmente válida quando se especula acerca da admissibilidade das ações coletivas passivas envolvendo interesses individuais homogêneos.

Em torno da competência, expusemos os pressupostos legais presentes no art. 93 do CDC, e apoiamos nossas considerações no espírito centralizador que, por razões de eficiência, deve guiar o manejo de ações coletivas. Assim, em última análise, defendemos que, em causas que envolvam direitos individuais homogêneos por dano de âmbito nacional, convém priorizar a competência do juízo do Distrito Federal. 
Quando nos dedicamos ao estudo da prova, veio à lume a interessante teoria das cargas dinâmicas do ônus da prova, acompanhada dos requisitos da verossimilhança das alegações do autor coletivo e da sua vulnerabilidade técnica em confronto com o agente do dano. Ao lado disso, abordamos os debates sobre o momento apropriado para a decisão sobre a inversão do ônus da prova e nos filiamos à corrente doutrinária que sugere ao juiz um prévio alerta às partes sobre a possibilidade da inversão, relegando para a sentença a adoção motivada desse critério de julgamento.

Ao avançarmos para o tema da relação entre o processo coletivo e as ações individuais, passamos a analisar um dos mais relevantes aspectos da tutela coletiva dos interesses individuais homogêneos, que consiste na livre adesão do indivíduo à ação coletiva. Não ignoramos que é envolvente a tese da suspensão obrigatória das ações individuais face uma ação coletiva, quando o espírito é atender ao escopo de resolução tempestiva dos litígios. Mas, nas atuais bases em que erigido o sistema, acreditamos que a mencionada liberdade de adesão seja um dos seus pilares que não podem ser ignorados.

Adicionando esse raciocínio à falta de controle rigoroso e profundo da representatividade do autor coletivo e às dificuldades de comunicação com os membros da coletividade, defendemos a opção do legislador de 1990 pelo transporte secundum eventum litis da coisa julgada coletiva para a esfera individual.

Mas observamos que, para a fase atual de desenvolvimento tecnológico e das organizações judiciárias, é muito positivo o paulatino caminhar para um modelo mais eficiente. Assim, das experiências com o CDC, podemos evoluir para uma sistemática mais inclusiva (opt out) e fortalecedora da dimensão do grupo, atendendo à aspiração de uma justiça tempestiva e tanto quanto possível integral. Neste ponto foi essencialmente enfatizado o olhar funcional e instrumental para o processo coletivo em defesa de direitos individuais homogêneos.

Em continuação, examinamos os aspectos procedimentais da liquidação e da execução da sentença coletiva genérica. Diversamente do espírito norteador da definição da competência, demos destaque à constatação de que prevalece a dispersão das liquidações e execuções individuais, sem prejuízo da reparação coletiva residual consistente na fluid recovery.

Alcançado o tema das outras técnicas de resolução dos conflitos de massa, preconizamos especial atenção do intérprete para o resguardo do objeto das ações 
coletivas. Então, foram buscadas as origens e os fundamentos de direito comparado para a improcedência prima facie da demanda com fulcro no art. 285-A do CPC, a súmula impeditiva de recursos e o incidente de resolução de demandas repetitivas.

Esses elementos ampararam a proposta de harmonizar os novos mecanismos de gestão dos processos repetitivos com as garantias inerentes aos processos coletivos e às pretensões individuais correlatas. Vale dizer, na existência de ação coletiva cujo objeto seja direitos homogêneos, não pode o emprego das técnicas de julgamento por amostragem (na linguagem vulgar, por atacado) sobrepor-se ao princípio da liberdade de adesão das pretensões individuais à ação coletiva em curso.

Ainda dentre as soluções heterocompositivas das controvérsias de massa, a arbitragem também foi estudada. De um lado porque, em geral, vem ganhando cada dia mais credibilidade, em função de sua acertividade, eficiência e celeridade. De outro lado, para o tema em estudo, o debate teve contornos peculiares.

Para se concluir pela arbitrabilidade dos direitos individuais homogêneos, foi preciso propor uma superação das barreiras práticas surgidas com: (i) as restrições impostas à cláusula compromissória nos contratos de adesão, ou (ii) a inexistência de suporte contratual (e, portanto, sequer de cláusula compromissória) para a responsabilização dos danos causados às vítimas do ato lesivo.

Dos meios autocompositivos de solução de litígios, buscamos extrair as vantagens e propor caminhos que amenizem o seu baixo grau de eficiência.

Por fim, dedicaram-se alguns capítulos à descrição das regras vigentes em alguns países ocidentais. Selecionamos as experiências das ações populares de Portugal, das ações coletivas para a tutela dos consumidores da Itália, das class actions dos Estados Unidos da América, das ações de grupo da Colômbia e das ações coletivas da Província de Rio Negro na Argentina. Os capítulos são descritivos e, sobre os aspectos que já não tenham sido abordados no decorrer do trabalho, foram feitos juízos críticos.

Assim, esperamos ter alcançado o escopo deste trabalho, com a profundidade e a extensão adequadas. 


\section{BIBLIOGRAFIA}

ALMEIDA, Luiz Cláudio Carvalho de. A Legitimidade do Ministério Público para a defesa dos direitos individuais homogêneos do consumidor, in Revista de Direito do Consumidor, n. 52, ano 13, outubro a dezembro de 2004.

ALMEIDA, Renato Franco de. O Parquet na defesa dos direitos individuais homogêneos, in Revista Forense, vol. 362, ano 98, julho a agosto de 2002.

ALVIM, Eduardo Arruda. Apontamentos sobre o processo das ações coletivas, in Processo Civil Coletivo, coord. Rodrigo Mazzei e Rita Dias Nolasco, São Paulo, Quartier Latin, 2005 .

ALVIM, Thereza. O direito processual de estar em juízo, São Paulo, Revista dos Tribunais, 1996.

AMARAL, Ana Lúcia e FRISCHEISEN, Luiza Cristina Fonseca. Legitimidade do Ministério Público para defesa dos interesses individuais homogêneos em matéria previdenciária e tributária, in Boletim dos Procuradores da República, ano 1, n. 4, agosto de 1998.

AMARAL, Guilherme Rizzo. Efetividade, segurança, massificação e a proposta de um 'incidente de resolução de demandas repetitivas', in Revista de Processo, vol. 196, junho de 2011.

AMARAL, Paulo Osternack. Vantagens, Desvantagens e peculiaridades da arbitragem envolvendo o Poder Público, in Arbitragem e Poder Público, São Paulo, Saraiva, 2010.

ANDRADE, Tathyana Chaves de, GABBAY, Daniela Monteiro, LUCON, Paulo Henrique dos Santos, ALVES, Rafael Francisco. Interpretação do pedido e da causa de pedir nas demandas coletivas (conexão, continência e litispendência), in Tutela Coletiva - 20 anos da Lei da Ação Civil Pública e do fundo de defesa dos interesses difusos, 15 anos do Código de Defesa do Consumidor, São Paulo, Atlas, 2006.

ANDREWS, Neil. O moderno processo civil: formas judiciais e alternativas de resolução de conflitos na Inglaterra (orient. trad. Teresa Arruda Alvim Wambier), São Paulo, Revista dos Tribunais, 2009.

ANDRIGHI, Nancy. Reflexões acerca da representatividade adequada nas ações coletivas passivas, disponível em: <http://bdjur.stj.jus.br/dspace/handle/2011/40618>, acesso em $23 / 11 / 2011$ 
ARENHART, Sérgio Cruz. O regime da prescrição em ações coletivas, in Em defesa de um Novo Sistema de Processos Coletivos - Estudos em Homenagem a Ada Pellegrini Grinover (coord. Maria Clara Gozzoli, Mirna Cianci, Petrônio Calmon e Rita Quartieri), São Paulo, Saraiva, 2010.

AROCA, Juan Montero. Il processo civile "sociale" come strumento di giustizia autoritaria, in Rivista di Diritto Processuale, 2004, 2; em espanhol in Actualidad Civil, 2004, março, segunda quinzena, n. 6, disponível em <http://egacal.educativa.com/upload/JMA_Montero01.pdf>, acesso em 6/11/2011.

APRIGLIANO, Ricardo de Carvalho. Ordem Pública e Processo - o tratamento das questões de ordem pública no direito processual civil, São Paulo, Atlas, 2011.

ASSIS, Araken de. Manual do Processo de Execução, $4^{\mathrm{a}}$ ed., São Paulo, Revista dos Tribunais, 1997.

BAPTISTA DA SILVA, Ovídio A. Sentença e coisa julgada - ensaios, Porto Alegre, Sergio Antonio Fabris, 1979.

BARBOSA, Carla Andrea, e CANTOARIO, Diego Martinez Fervenza. O incidente de resolução de demandas repetitivas e o projeto de Código de Processo Civil: apontamentos iniciais, in $\mathrm{O}$ novo Processo Civil brasileiro: direito em expectativa (Luiz Fux coord.), Rio de Janeiro, Forense, 2011.

BARBOSA MOREIRA, José Carlos. A ação civil pública e a língua portuguesa, in Ação Civil Pública - Lei 7.347/1985 - 15 anos (coord. Édis Milaré), 2ª ed., São Paulo, Revista dos Tribunais, 2002.

A ação popular no direito brasileiro como instrumento de tutela jurisdicional dos chamados "interesses difusos", in Temas de Direito Processual Primeira Série, $2^{\text {a }}$ ed., São Paulo, Saraiva, 1988.

Ações coletivas na Constituição Federal de 1988, in Revista de Processo $\mathrm{n}^{\circ}$ 61, janeiro/março de 1991, pp. 187/200.

A expressão "competência funcional" no art. $2^{\mathrm{a}}$ da Lei da Ação Civil Pública, in Ação Civil Pública após 20 anos: efetividade e desafios (coord. Édis Milaré), São Paulo, Revista dos Tribunais, 2005.

Apontamentos para um estudo sistemático da legitimação extraordinária, Revista dos Tribunais, n. 404, 1969.

A proteção jurídica dos interesses coletivos, in Temas de direito processual - terceira série, São Paulo, Saraiva, 1984. 
Considerações sobre a chamada "relativização" da coisa julgada, in Temas de Direito Processual - Nona Série, São Paulo, Saraiva, 2007.

. Eficácia da sentença e autoridade da coisa julgada, in Temas de Direito Processual Civil - Terceira Séria, São Paulo, Saraiva, 1984.

. Julgamento e ônus da prova, in Temas Direito Processual $-2^{\mathrm{a}}$ série, São Paulo, Saraiva, 1988.

La iniciativa en la defensa judicial de los intereses difusos y colectivos (un aspecto de la experiencia brasileña), in Revista de Processo, n. 68, ano 17, outubro a dezembro de 1992.

Litisconsórcio unitário, Rio de Janeiro, Forense, 1972.

. Notas sobre o problema da efetividade do processo, in Temas de Direito Processual - Terceira Série, São Paulo, Saraiva, 1984.

- O direito à assistência jurídica: evolução no ordenamento brasileiro de nosso tempo, in Revista de Processo, n. 67, ano 17, julho a setembro de 1992.

Tendências contemporâneas do direito processual civil, in Temas de Direito Processual Civil - Terceira Série, São Paulo, Saraiva, 1984.

. Tutela jurisdicional dos interesses coletivos ou difusos, in Temas de Direito Processual Civil - Terceira Série, São Paulo, Saraiva, 1984.

BEDAQUE, José Roberto dos Santos. Direito e processo - influência do direito material sobre o processo, $5^{\text {a }}$ ed., São Paulo, Malheiros, 2009.

Efetividade do Processo e Técnica Processual, $2^{\mathrm{a}}$

ed., São Paulo, Malheiros, 2007.

O Ministério Público no processo civil: algumas questões polêmicas, in Revista de Processo, vol. 16, n. 61, janeiro a março de 1991.

BENJAMIM, Antônio Herman V. A insurreição da aldeia global contra o processo civil clássico, in Ação civil pública - Lei 7.347/85 - Reminiscências e reflexões sobre dez anos de aplicação (coord. Édis Milaré), São Paulo, Revista dos Tribunais, 1995.

BOAVENTURA PACÍFICO, Luiz Eduardo. O ônus da prova no Direito Processual Civil, São Paulo, Revista dos Tribunais, 2000.

BONÍCIO, Marcelo José Magalhães, e YARSHELL, Flávio Luiz. Execução civil - novos perfis, São Paulo, RCS, 2006.

BOTELHO DE MESQUITA, José Ignacio. A coisa julgada, Rio de Janeiro, Forense, 2006. BUZAID, Alfredo. Estudos de Direito, São Paulo, Saraiva, 1972. 
CABRAL, Antonio de Passo. O novo procedimento-modelo (musterverfahren) alemão: uma alternativa às ações coletivas, in Revista de Processo, vol. 147, maio de 2007.

CALMON DE PASSOS, J. J. Mandado de segurança coletivo, mandado de injunção, habeas data - Constituição e processo, Rio de Janeiro, Forense, 1989.

CAMBI, Eduardo. A Prova Civil - Admissibilidade e Relevância, São Paulo, Revista dos Tribunais, 2006.

Coisa julgada e cognição secundum eventum probationis, in Revista de Processo, vol. 109, janeiro de 2003.

Julgamento prima facie (imediato) pela técnica do art. 285-A do CPC, in Revista dos Tribunais, vol. 854, dezembro de 2006, disponível em Revista dos Tribunais on line, acesso em 1\%/10/2011.

CAPPELLETTI, Mauro e GARTH, Bryant. Acesso à justiça (tradução de Ellen Gracie Northfleet), Porto Alegre, Sergio Antonio Fabris, 2002.

Appunti sulla tutela giurisdizionale di interessi collettivi o diffusi, in Le azioni a tutela di interessi collettivi: atti del convegno di Studio, Pádua, Cedam, 1976.

Formações sociais e interesses coletivos diante da justiça civil, São Paulo, in Revista de Processo, n. 5, janeiro a março de 1977.

O acesso à justiça e a função do jurista em nossa época, in Revista de Processo, n. 61, janeiro a março de 1991.

CAPONI, Remo. Modelo europeu de tutela coletiva no processo civil: comparação entre a experiência alemã e italiana, Revista de Processo, vol. 200, outubro de 2011.

CARMONA, Carlos Alberto. Arbitragem e processo - um comentário à Lei no 9.307/96, $3^{\mathrm{a}}$ ed., São Paulo, Atlas, 2009.

CARNEIRO, Athos Gusmão. Direitos individuais homogêneos, limitações à sua tutela pelo Ministério Público, in Revista de Processo, ano 26, n. 103, julho a setembro de 2001.

Da competência no projeto de lei de nova ação civil pública, in Em defesa de um Novo Sistema de Processos Coletivos - Estudos em Homenagem a Ada Pellegrini Grinover (coord. Maria Clara Gozzoli, Mirna Cianci, Petrônio Calmon e Rita Quartieri), São Paulo, Saraiva, 2010.

. Intervenção de terceiros, $16^{\mathrm{a}}$ ed., São Paulo, Saraiva, 2006. Jurisdição e competência, 2ª ed., São Paulo, Saraiva, 1983. 
CARNEIRO, José Reinaldo Guimarães. O Ministério Público e suas investigações independentes, São Paulo, Malheiros, 2007.

CARNELUTTI, Francesco. Instituciones del Proceso Civil (trad. Santiago Sentis Melendo), tomo I, Ediciones Juridicas Europa-America, 1950.

CARVALHO, Ivan Lira de. O mandado de segurança coletivo e os partidos políticos, disponível em <http://www.plenum.com.br/plenum_jp/lpext.dll/Dou/douciv/110d/1227/125f?fn=documentframe.htm\&f=templates\&2.0>, acesso em 30/06/2011.

CARVALHO, Leandro Coelho de. As atribuições da Defensoria Pública sob a ótica do acesso à ordem jurídica justa, in Revista de processo, n. 156, ano 33, fevereiro 2008.

CHAYES, Abram. The role of the judge in public law litigation, in Harvard Law Review, vol. 89, maio de 1976, pp. 1281/1315.

CHIOVENDA, Giuseppe. Principios de Derecho Procesal Civil, tomo II, Madri, Editorial Reus, 1925.

CINTRA, Antonio Carlos Araújo. Comentários ao Código de Processo Civil, vol. IV, $2^{\mathrm{a}}$ ed., Rio de Janeiro, Forense, 2003.

. Estudo sobre a substituição processual no direito brasileiro, in Revista dos Tribunais, ano 61, v. 438, abril de 1972.

, et. al. Teoria Geral do Processo, $11^{\mathrm{a}}$ ed., São Paulo,

Malheiros, 1995.

COSTA E SILVA, Antônio Carlos. Tratado do Processo de Execução, vol. I, $2^{a}$ ed., Rio de Janeiro, AIDE, 1986.

COSTA MACHADO, Antonio Cláudio. A intervenção do Ministério Público no Processo Civil brasileiro, São Paulo, Saraiva, 1989.

COSTA, Susana Henriques da. O processo coletivo na tutela do patrimônio público e da moralidade administrativa, São Paulo, Quartier Latin, 2009. . Condições da ação, São Paulo, Quartier Latin, 2005.

. O controle judicial da representatividade adequada: uma análise dos sistemas norte-americano e brasileiro, in As Grandes Transformações do Processo Civil Brasileiro: homenagem ao Professor Kazuo Watanabe (org. Carlos Alberto de Salles), São Paulo, Quartier Latin, 2009.

COUTURE, Eduardo. Fundamentos del derecho procesal civil, $3^{\mathrm{a}}$ ed., Buenos Aires, Depalma, 1958.

CRUZ E TUCCI, José Rogério. Código do consumidor e processo civil, São Paulo, v. 80, n. 671, p. $32 / 39$. 
. Class action e mandado de segurança coletivo, São Paulo,

Saraiva, 1990.

- Limites subjetivos da eficácia da sentença e da coisa julgada civil, $1^{\text {a }}$ e 2a ed., São Paulo, Revista dos Tribunais, 2006 e 2007.

- Limites subjetivos da eficácia da sentença e da coisa julgada nas ações coletivas, in Revista de Processo, vol. 143, janeiro de 2007.

DENTI, Vittorio. Il ruolo del giudice nel processo civile tra vecchio e nuovo garantismo, in Rivista Trimestrale de Diritto e Procedura Civile, Milão, v. 38, setembro de 1984.

Giustizia e partecipazione nella tutela dei nuovi diritti, in Participação e

Processo (coord. Ada Pellegrini Grinover, Cândido Rangel Dinamarco e Kazuo Watanabe), São Paulo, Revista dos Tribunais, 1988.

DIDIER JR., Fredie, ZANETI JR., Hermes. Curso de Direito Processual Civil - Processo coletivo, vol. IV, $4^{\text {a }}$ ed., Salvador, Juspodivm, 2009.

DINAMARCO, Cândido Rangel. A Reforma do Código de Processo Civil, $2^{\mathrm{a}}$ ed., São Paulo, Malheiros, 1995 e 2001.

Execução Civil, $5^{\text {a }}$ ed., São Paulo, Malheiros, 1997. . Instituições de Direito Processual Civil, vols. I, II, III e

IV, $5^{\text {a e }} 6^{\text {a }}$ ed., São Paulo, Malheiros, 2005 e 2009.

. Instrumentalidade do processo, $11^{\mathrm{a}}$ ed., São Paulo

Malheiros, 2003.

, et. al. Teoria Geral do Processo, $11^{\mathrm{a}}$ ed., São Paulo,

Malheiros, 1995.

DINAMARCO, Pedro da Silva. Ação civil pública, São Paulo, Saraiva, 2001. . Competência, conexão e prevenção nas ações coletivas, in

Ação Civil Pública após 20 anos: efetividade e desafios (coord. Édis Milaré), São Paulo, Revista dos Tribunais, 2005.

DIZ, Nelson Nascimento. Apontamentos sobre a legitimação das entidades associativas para a propositura de ações coletivas em defesa de direitos individuais homogêneos de consumidores, in Aspectos polêmicos da ação civil pública (coord. Arnoldo Wald), São Paulo, Saraiva, 2003.

DUARTE, Paulo. Recurso e acórdão do Supremo Tribunal de Justiça de Portugal - Ação popular e interesses individuais homogêneos (colaboração de Ada Pellegrini Grinover), in Revista de Processo, outubro a dezembro de 1997, n. 88, v. 22. 
ECHANDIA, Hernando Devis. Teoria General de la Prueba Judicial, tomo II, Buenos Aires, Victor P. de Zavalia, 1981.

FAZZALLARI, Elio. Istituizioni di Diritto Processuale, $5^{\text {a }}$ ed., Padova, Cedam, 1989.

FERRARESI, Eurico. Ação popular, ação civil pública e mandado de segurança coletivo Instrumentos processuais coletivos, Rio de Janeiro, Forense, 2009.

FONSECA, João Francisco Naves da. O julgamento liminar de improcedência da demanda (art. 285-A): questões polêmicas, disponível em <http://www.trepb.gov.br/eje/pdf/Novo_CPC_Artigo.pdf>, acesso em 5/11/2011.

FONTES, Paulo Gustavo Guedes. Legitimidade do MP para a defesa dos interesses individuais homogêneos: importância em face do caráter individualista do controle judicial da Administração no Brasil, in Revista Brasileira de Direito Público, Belo Horizonte, ano 6, n. 20, janeiro a março de 2008.

FORNACIARI, Flávia Hellmeister Clito. Representatividade adequada nos processos coletivos, tese de doutorado apresentada perante a Faculdade de Direito da Universidade de São Paulo, 2010.

FILHO, Roberto Gonçalves Freitas. A legitimidade da Defensoria Pública para propor ação civil pública, in Revista IOB de Direito Civil e Processual Civil, ano IX, n. 59, maio a junho de 2009.

FISS, Owen. Um novo processo civil: estudos norte-americanos sobre jurisdição, constituição e sociedade, São Paulo, Revista dos Tribunais, 2004.

FREITAS, José Lebre de. A acção popular ao serviço do ambiente, in Revista de Direito Ambiental, vol. 1, janeiro de 1996.

FROTA, Mário. Por um código de processo colectivo em Portugal, in Revista Jurídica do Ministério Público do Estado de Minas Gerais, Belo Horizonte, n. 14, janeiro a junho de 2010.

FURTADO, Paulo. Juízo Arbitral, 2ª ed., Salvador, Nova Alvorada, 1995.

GABBAY, Daniela Monteiro. Pedido e causa de pedir, São Paulo, Saraiva, 2010.

GAJARDONI, Fernando da Fonseca. O princípio constitucional da tutela jurisdicional sem dilações indevidas e o julgamento antecipadíssimo da lide, in Revista de Processo, vol. 141, novembro de 2006.

GARTH, Bryant e CAPPELLETTI, Mauro. Acesso à justiça (tradução de Ellen Gracie Northfleet), Porto Alegre, Sergio Antonio Fabris, 2002.

GIDI, Antonio. A representação adequada nas ações coletivas brasileiras: uma proposta, in Revista de Processo, vol. 108, n. 61, 2002. 
Aspectos da Inversão do Ônus da Prova no Código do Consumidor, in Genesis - Revista de Direito Processual Civil, Curitiba, setembro a dezembro de 1996. . Class action como instrumento de tutela coletiva de direitos - as ações coletivas em uma perspectiva comparada, São Paulo, Revista dos Tribunais, 2007.

. Código de Processo Civil Coletivo - um modelo para países de direito escrito, Revista de Processo, n. 111, ano 28, julho a setembro de 2003. , e MAC-GREGOR, Eduardo Ferrer. Comentários ao Código Modelo de Processos Coletivos - um diálogo ibero-americano, Salvador, Juspodivm, 2009. . Coisa julgada e litispendência em ações coletivas, São Paulo, Saraiva, 1995.

e MAC-GREGOR, Eduardo Ferrer. La tutela de los derechos difusos, colectivos e individuales homogéneos, $2^{\mathrm{a}}$ ed., México, Porrúa, 2004.

. Rumo a um Código de Processo Civil Coletivo: a codificação das ações coletivas do Brasil, Rio de Janeiro, Forense, 2008.

GOMES, Luiz Manoel Gomes Júnior e FAVRETO, Rogério. Comentários à nova lei do mandado de segurança, São Paulo, Revista dos Tribunais, 2009.

GRAU, Eros Roberto. Da arbitrabilidade de litígios envolvendo sociedades de economia mista e da interpretação de cláusula compromissória, in Revista de Direito Bancário e do Mercado de Capitais, vol. 18, outubro de 2002.

GRINOVER, Ada Pellegrini. Acesso à justiça e o Código de Defesa do Consumidor, in O Processo em sua evolução, Rio de Janeiro, Forense Universitária, 1996.

. A ação civil pública refém do autoritarismo, in $\mathrm{O}$ processo estudos e pareceres, DPJ, São Paulo, 2005.

. A Ação Civil Pública no STJ, in A Marcha do Processo, Rio de Janeiro, Forense Universitária, 2000.

Ação popular portuguesa: uma análise comparativa, in Revista de Processo, vol. 21, n. 83, julho de 1996.

Ações coletivas Ibero-Americanas: novas questões sobre legitimação e a coisa julgada, in Revista Forense, v. 361, 2002.

A tutela jurisdicional dos interesses difusos no direito comparado, in A tutela dos interesses difusos, São Paulo, Max Limonad, 1984. , et. al. Código Brasileiro de Defesa do Consumidor comentado pelos autores do anteprojeto, $5^{\mathrm{a}}, 6^{\mathrm{a}}, 9^{\mathrm{a}}$ e $10^{\mathrm{a}}$ ed. (vol. II), Rio de Janeiro, Forense Universitária, 1998, 2000, 2007 e 2011. 
Conferência sobre Arbitragem na Tutela dos Interesses Difusos e Coletivos, in Revista de Processo, vol. 136, junho de 2006.

. Da class action for damages à ação de classe brasileira: os requisitos de admissibilidade, in Revista de Processo, n. 101, ano 26, janeiro a março de 2001, pp. 11/27.

Da class action for damages à ação de classe brasileira: os requisitos de admissibilidade, in Ação Civil Pública - Lei 7.347/1985 - 15 anos (coord. Édis Milaré), 2a ed., São Paulo, Revista dos Tribunais, 2002.

Direito Processual Coletivo, in Tutela Coletiva: 20 anos da Lei da Ação Civil Pública e do Fundo de Defesa de Direitos Difusos e 15 anos do Código de Defesa do Consumidor (coord. Paulo Henrique dos Santos Lucon), São Paulo, Atlas, 2006.

. Mudanças estruturais no processo civil brasileiro, in Revista de Direitos e Garantias Fundamentais, n. 1, 2006.

- Novas Tendências do Direito Processual Civil, Rio de Janeiro, Forense Universitária, 1990.

- Novas tendências na tutela jurisdicional dos interesses difusos, in O processo em sua unidade II, Rio de Janeiro, Forense, 1984.

, et. al. Os processos coletivos nos países de Civil Law e Common Law - uma análise de direito comparado, $1^{\text {a }}$ e $2^{\mathrm{a}}$ ed., São Paulo, Revista dos Tribunais, 2008 e 2011.

. Interesses difusos, Enciclopédia Saraiva do Direito, v. 45.

. Parlamento Europeu e Conselho: Diretiva 2009/22 CE de

23.04.2009: as ações inibitórias de tutela do consumidor, in Revista de Processo, vol. 175 , setembro de 2009.

. Significado social, político e jurídico da tutela dos interesses difusos, in Revista de Processo, n. 97, janeiro a março de 2000.

et. al. Teoria Geral do Processo, $11^{\text {a }}$ ed., São Paulo, Malheiros, 1995.

KRELL, Andreas J. Ordem jurídica e meio ambiente na Alemanha e no Brasil: alguns aspectos comparativos, in Revista de Direito Ambiental, vol. 31, julho de 2003.

LASPRO, Oreste Nestor de Souza. Duplo grau de jurisdição no direito processual civil, São Paulo, Revista dos Tribunais, 1995. 
LEITE, Carlos Henrique Bezerra. A legitimação do Ministério Público para promover a defesa dos interesses individuais homogêneos, in Repertório Jurisprudência IOB, n. $16,2001$.

LENZA, Pedro. Assistência jurídica, integral e gratuita e o fortalecimento da Defensoria Pública na Reforma do Judiciário, in Reforma do Judiciário analisada e comentada: Emenda Constitucional 45/2004 (coord. André Ramos Tavares, Pedro Lenza e Pietro de Jesús Lora Alarcón), Método, São Paulo, 2005.

. Direito Constitucional Esquematizado, 9a ed., São Paulo, Método, 2005. . Teoria geral da ação civil pública, $2^{\mathrm{a}}$ e $3^{\mathrm{a}}$ ed., São Paulo, Revista dos Tribunais, 2005 e 2008.

LEONEL, Ricardo de Barros. Manual do Processo Coletivo, $2^{a}$ ed., São Paulo, Revista dos Tribunais, 2011.

LIEBMAN, Enrico Tullio. Manual de Direito Processual Civil (trad. Cândido Rangel Dinamarco), $3^{\text {a }}$ ed., vol. I, São Paulo, Malheiros, 2005. - Eficácia e autoridade da sentença (tradução de Alfredo Buzaid, Benvindo Aires e notas de Ada Pellegrini Grinover), $3^{\mathrm{a}}$ ed., Rio de Janeiro, Forense, 1984.

LOPES, João Batista. A prova no direito processual civil, $2^{\mathrm{a}}$ ed., São Paulo, Revista dos Tribunais, 2002.

LOPES, José Reinaldo de Lima. Direitos Sociais - teoria e prática, São Paulo, Método, 2006.

LUCON, Paulo Henrique dos Santos, e SILVA, Érica Barbosa e. Análise crítica da liquidação e execução na tutela coletiva, in Tutela Coletiva - 20 anos da Lei da Ação Civil Pública e do fundo de defesa dos interesses difusos, 15 anos do Código de Defesa do Consumidor, São Paulo, Atlas, 2006.

LUHMANN, Nicklas. Legitimação pelo procedimento (trad. Maria da Conceição CôrteReal), Brasília, UnB, 1980 e 1981.

MACEDO JR., Ronaldo Porto. Ação civil pública, o direito social e os princípios, in Estudos em Homenagem à Professora Ada Pellegrini Grinover (Flávio Luiz Yarshell e Maurício Zanoide de Moraes coord.), São Paulo, DPJ, 2005.

MAC-GREGOR, Eduardo Ferrer, e GIDI, Antonio. Comentários ao Código Modelo de Processos Coletivos - um diálogo ibero-americano, Salvador, Juspodivm, 2009. e GIDI, Antonio. La tutela de los derechos difusos, colectivos, e individuales homogéneos, $2^{\text {a }}$ ed., México, Porrúa, 2004. 
MACHADO, Hugo de Brito. O Ministério Público e os direitos individuais homogêneos, in Repertório Jurisprudência IOB, n. 18, 1998.

MAGALHÃES, José Carlos de, e BAPTISTA, Luiz Olavo. Arbitragem comercial, Rio de Janeiro, Freitas Bastos, 1986.

MAIA, Diogo Campos Medina. A ação coletiva passiva: o retrospecto histórico de uma necessidade presente, in Direito Processual Coletivo e o anteprojeto de Código Brasileiro de Processos Coletivos, São Paulo, Revista dos Tribunais, 2007.

MANCUSO, Rodolfo de Camargo. Ação civil pública, 12ª ed., São Paulo, Revista dos Tribunais, 2011.

Ação Popular, $3^{\mathrm{a}}, 5^{\mathrm{a}}$ e $6^{\mathrm{a}}$ ed., São Paulo, Revista dos

Tribunais, 1998, 2003 e 2008.

A resolução dos conflitos e a função judicial no contemporâneo Estado de Direito, São Paulo, Revista dos Tribunais, 2009.

A resolução dos conflitos e a função judicial no contemporâneo Estado de Direito (nota introdutória), in Revista dos Tribunais, vol. 888, outubro de 2009.

Contribuições esperadas do Ministério Público e da

Defensoria Pública na prevenção da atomização judicial dos megaconflitos, in Revista de Processo, vol. 33, n. 164, outubro de 2008.

Defesa do Consumidor: reflexões acerca da eventual concomitância de ações coletivas e individuais, disponível em Revista dos Tribunais on line, acesso em 30/08/2011.

Divergência Jurisprudencial e Súmula Vinculante, $3^{\mathrm{a}}$

ed., São Paulo, Revista dos Tribunais, 2007.

Interesses difusos: conceito e colocação no quadro geral dos 'interesses', in Revista de Processo no 55, julho a setembro de 1989, São Paulo, Revista dos Tribunais.

Interesses difusos: conceito e legitimação para agir, $6^{\mathrm{a}}$ e $7^{\mathrm{a}}$ ed., São Paulo, Revista dos Tribunais, 2004 e 2011.

Jurisdição coletiva e coisa julgada, $2^{a}$ ed., São Paulo,

Revista dos Tribunais, 2007.

O Município enquanto co-legitimado para a tutela

dos interesses difusos, in Revista de Processo, vol. 12, n. 48, outubro a dezembro de 1987. 
- Sobre a legitimação do Ministério Público em matéria de interesses individuais homogêneos, in Ação civil pública - Lei 7.347/85 Reminiscências e reflexões após dez anos de aplicação, São Paulo, Revista dos Tribunais, 1995.

. Transposição das águas do Rio São Francisco: uma abordagem jurídica da controvérsia, disponível em Revista dos Tribunais on line, acesso em 30/08/2011.

MAJO, Adolfo di. La tutela civile dei diritti, 2a ed., vol. III, Milão, Giuffrè, 1993.

MARINONI, Luiz Guilherme, Ações repetitivas e julgamento liminar, in Revista dos Tribunais, vol. 858, abril de 2007.

, e Arenhart, Sérgio Cruz, Curso de Processo Civil -

Procedimentos Especiais, vol. V, 2a ed., São Paulo, Revista dos Tribunais, 2010.

- Eficácia temporal da revogação da jurisprudência

consolidada dos Tribunais Superiores, in Revista dos Tribunais, vol. 906, abril de 2011.

MARQUES, José Frederico. Manual de Direito Processual Civil, vol. I, 10ª ed., São Paulo, Saraiva, 1983.

Instituições de Direito Processual Civil, vol. IV, Campinas, Millennium, 2000.

MARTINS, Ives Gandra da Silva. Ministério público - Direitos individuais disponíveis e ação civil pública, in Revista Forense, vol. 330, ano 91, abril a junho de 1995.

MARTINS, Pedro Batista. A arbitragem e o mito da sentença parcial, in Arbitragem: estudos em homenagem ao Prof. Guido Fernandes da Silva Soares, São Paulo, Atlas, 2007.

Arbitragem e o setor de telecomunicações no Brasil, in Revista de Arbitragem e Mediação, vol. 9, abril de 2006.

Anotações Sobre a Arbitragem no Brasil e o Projeto de lei do Senado 78/92, in Revista de Processo, vol. 77, janeiro de 1995.

MARTINS, Raphael Manhães. A Defensoria Pública e o acesso à justiça, in Revista CEJ, n. 30, julho a setembro de 2005 .

MATOS, Cecília. Ônus da Prova no Código de Defesa do Consumidor, dissertação de Mestrado apresentada perante a Faculdade de Direito da Universidade de São Paulo, 1993. 
MAZZEI, Rodrigo Reis. Tutela coletiva em Portugal: uma breve resenha, in Revista Jurídica do Ministério Público do Estado de Minas Gerais, Belo Horizonte, n. 7, julho a dezembro de 2006.

MAZZILLI, Hugo Nigro. A defesa dos interesses difusos em juízo, $16^{\mathrm{a}}$, $20^{\mathrm{a}}$ e $22^{\mathrm{a}}$ ed., São Paulo, Saraiva, 2003 e 2009.

MEDINA, José Manoel Garcia, e ARAÚJO, Fábio Caldas de. Mandado de segurança individual e coletivo, comentários à Lei 12.016, de 7 de agosto de 2009, São Paulo, Revista dos Tribunais, 2009.

e WAMBIER, Teresa Arruda Alvim, O Dogma da coisa julgada - hipóteses de relativização, São Paulo, Revista dos Tribunais, 2003.

MENCHINI, Sergio. Il giudicato civile, Turim, UTET, 1988.

MENEZES, Iure Pedroza. O precedente judicial e o art. 285-A do CPC, disponível em <http://bdjur.stj.gov.br/xmlui/bitstream/handle/2011/9799/O_\%20Precedente_Judicial _e_o_Art._285-A.pdf?sequence=1>, acesso em 5/11/2011.

MEIRELLES, Hely Lopes. Mandado de segurança, 28ª ed., São Paulo, Malheiros, 2005. . Mandado de segurança, ação popular e ação civil pública cit., São Paulo, Revista dos Tribunais, 1987.

MENDES, Aluísio Gonçalves de Castro. Ações coletivas no Direito Comparado e Nacional, $2^{a}$ ed., São Paulo, Revista dos Tribunais, 2010.

MICHELI, Gian Antonio. L'onere della prova, Padova, Cedam, 1966.

MIRANDA, Jorge. O Tratado de Maastricht e a Constituição Portuguesa, in Revista do Tribunal Regional Federal $1^{a}$ Região, Brasília, v. 8, n. 3, julho a setembro de 1996.

MIRRA, Álvaro Luiz Valery. A coisa julgada nas ações para tutela de interesses difusos, in Revista dos Tribunais, vol. 631, maio de 1988.

- Participação, processo civil e defesa do meio ambiente brasileiro, tese de doutorado apresentada perante a Faculdade de Direito da Universidade de São Paulo, 2010.

MONTELEONE, Girolamo A. I limiti soggettivi del giudicato civile, Padova, Cedam, 1978.

MORAES, André Medeiros. Arbitragem nas ações de consumo, Curitiba, Juruá, 2006.

MORELLO, Augusto M. La prueba - tendencias modernas, Buenos Aires, Abeledo-Perrot, 1991. 
MULLINEX, Linda, et. al. Os processos coletivos nos países de Civil Law e Common Law - uma análise de direito comparado, $1^{\mathrm{a}}$ e $2^{\mathrm{a}}$ ed., São Paulo, Revista dos Tribunais, 2008 e 2011.

NERY JR., Nelson. Aspectos do Processo Civil no Código de Defesa do Consumidor, in Revista de Direito do Consumidor, vol. 1, janeiro de 1992. , et. al. Código Brasileiro de Defesa do Consumidor comentado pelos autores do anteprojeto, $6^{\mathrm{a}}, 9^{\mathrm{a}}$ e $10^{\mathrm{a}}$ ed. (vol. II), Rio de Janeiro, Forense Universitária, 2000, 2007 e 2011.

, e NERY, Rosa Maria de Andrade. Código de Processo Civil Comentado e legislação extravagante, $3^{\mathrm{a}}$, $8^{\mathrm{a}}$ e $11^{\mathrm{a}}$ ed., São Paulo, Revista dos Tribunais, 2004 e 2010.

. O Ministério Público e as ações coletivas, in Ação Civil Pública (Lei 7.347/85 reminiscências e reflexões após dez anos de aplicação - coord. Édis Milaré), São Paulo, Revista dos Tribunais, 1995.

NUNES, Dierle José Coelho. Processo jurisdicional democrático, Curitiba, Juruá, 2009.

OLIVEIRA, Swarai Cervone de. Poderes do juiz nas ações coletivas, São Paulo, Atlas, 2009.

PASCHOAL, Maximilian Fierro. A representatividade adequada e a discussão quanto à possibilidade do seu controle judicial no Brasil, in As Grandes Transformações do Processo Civil Brasileiro: homenagem ao Professor Kazuo Watanabe (org. Carlos Alberto de Salles), São Paulo, Quartier Latin, 2009.

PENTEADO, Luciano de Camargo. Tutela coletiva de direitos individuais homogêneos, in Revista de Direito Privado, n. 19, ano 5, julho a setembro de 2001.

PERIN JR., Ecio. Aspectos relevantes da tutela coletiva do consumidor no direito italiano em face do direito comunitário europeu, in Revista de Direito do Consumidor, vol. 38, abril de 2001.

PIZZORUSSO, Alessandro. Partecipazione popolare e funzione giurisdizionale, in Participação e processo (coord. Ada Pellegrini Grinover, Cândido Rangel Dinamarco e Kazuo Watanabe), São Paulo, Revista dos Tribunais, 1988.

PIZZOL, Patrícia Miranda. A competência no processo civil, São Paulo, Revista dos Tribunais, 2003. . Liquidação nas ações coletivas, São Paulo, Lejus, 1998.

PONTES DE MIRANDA. Tratado de Direito Privado, vol. III, $3^{\text {a }}$ ed., Borsoi, Rio de Janeiro, 1970. 
PROENÇA, Luis Roberto. Inquérito civil - atuação investigativa do Ministério Público a serviço da ampliação do acesso à Justiça, São Paulo, Revista dos Tribunais, 2001.

PRUDENTE, Antonio de Souza. Legitimação constitucional do Ministério Público para ação civil pública em matéria tributária na defesa de direitos individuais homogêneos, in Revista CEJ, n. 9, dezembro de 1999.

PRÜTTING, Hanns. Carga de la prueba y estándar probatorio: La Influencia de Leo Rosenberg y Karl Hainz Schwab para el desarrollo del moderno Derecho probatório, in Revista Ius et Praxis, Ano 16, n. 1, 2010, Talca-Chile.

PUOLI, José Carlos Baptista. Responsabilidade Civil do Promotor de Justiça, São Paulo, Juarez de Oliveira, 2007.

RÉ, Aluísio Iunes Monti Ruggeri. A Defensoria Pública como instrumento de acesso à Justiça coletiva: legitimidade ativa e pertinência temática, in Revista dos Tribunais, v. $167,2009$.

REICH, Norbert. Algumas proposições para a filosofia da proteção do consumidor, in Revista dos Tribunais, vol. 728, junho de 1996.

RIBEIRO, Débora de Oliveira. Inversão do ônus da prova no Código de Defesa do Consumidor, dissertação de Mestrado apresentada perante a Faculdade de Direito da Universidade de São Paulo, 2005.

RODRIGUES, Geisa de Assis. Ação civil pública e termo de ajustamento de conduta: teoria e prática, $2^{\mathrm{a}}$ ed., Rio de Janeiro, Forense, 2006.

RODRIGUES, Marcelo Abelha. A distribuição do ônus da prova no Anteprojeto do Código Brasileiro de Processos Coletivos, in Direito Processual Coletivo e o anteprojeto de Código Brasileiro de Processos Coletivos, São Paulo, Revista dos Tribunais, 2007. , e Rodrigo Klippel, A homologação judicial do TAC e a formação da coisa julgada coletiva em matéria ambiental, in O Novo Processo Civil Coletivo (coord. Guilherme José Purvin de Figueiredo e Marcelo Abelha Rodrigues), Rio de Janeiro, Lumen Juris, 2009.

Ponderações sobre a fluid recovery no art. 100 do CDC, in Revista de Processo, vol. 116, julho de 2004.

RODRIGUES, Ruy Zoch. Ações repetitivas - Casos de antecipação de tutela sem o requisito de urgência, São Paulo, Revista dos Tribunais, 2010.

SALLES, Carlos Alberto de. Ações coletivas: premissas para comparação com o sistema jurídico norte-americano, in Processos coletivos e tutela ambiental (org. Carlos 
Alberto de Salles, Solange Telles da Silva e Ana Maria de Oliveira Nusdeo), Santos, Universitária Leopoldianum, 2006, pp. 17/33.

. Anteprojeto de nova lei da Ação Civil Pública - Propostas do Ministério Público de São Paulo, São Paulo, APMP, 2009.

Execução judicial em matéria ambiental, São Paulo, Revista dos Tribunais, 1999.

Políticas públicas e a legitimidade para defesa de interesses difusos e coletivos, in Revista de Processo, n. 121, ano 30, março de 2005.

Processo civil de interesse público: uma nova perspectiva metodológica, in Direito Processual Público - A Fazenda Pública em juízo, São Paulo, Malheiros, 2000, pp. 45/65.

SALVADOR, Antonio Raphael Silva. Ministério Público: exame de sua legitimidade para impetrar segurança e para defesa de interesses individuais homogêneos, in Revista da Escola Paulista da Magistratura, maio a outubro de 1997.

SANTOS, Ernane Fidélis dos. Manual de Direito Processual Civil, vol. I, $5^{\text {a }}$ ed., São Paulo, Saraiva, 1997.

SATTA, Salvatore. Diritto Processuale Civile, Padova, Cedam, 1981.

SCARPINELLA BUENO, Cássio. Amicus curiae: uma homenagem a Athos Gusmão Carneiro, disponível em <http://www.scarpinellabueno.com.br>; acesso em $30 / 10 / 2011$.

As class actions norte-americanas e as ações coletivas brasileiras: ponto para uma reflexão conjunta, in Revista de Processo, n. 82, abril a junho de 1996.

O poder público em juízo, $4^{\mathrm{a}}$ ed., São Paulo, Saraiva, 2008 Quatro perguntas e quatro respostas sobre o amicus curiae, in Revista Nacional da Magistratura, ano II, n. 5, Brasília, Escola Nacional da Magistratura/Associação dos Magistrados Brasileiros, maio de 2008.

SHIMURA, Sérgio. Tutela coletiva e sua efetividade, São Paulo, Método, 2006.

SILVA, Bruno Freire e. A inversão judicial do ônus da prova no Código de Defesa do Consumidor, in Aspectos Processuais do Código de Defesa do Consumidor (coord. Fabiano Carvalho e Rodrigo Barioni), vol. I, São Paulo, Revista dos Tribunais, 2008. SILVA, Edson Ferreira da. Da legitimação extraordinária, inclusive na Constituição de 1988, in Revista de Processo, v. 16, n. 64, outubro a dezembro de 1991. 
SILVA, Érica Barbosa e. Cumprimento de sentença nas ações coletivas, São Paulo, Atlas, 2009.

SILVA, José Afonso da. Ação popular constitucional, 2a ed., São Paulo, Malheiros, 2007.

SILVA ARAÚJO FILHO, Luiz Paulo da. Ações coletivas: a tutela jurisdicional dos direitos individuais homogêneos, Rio de Janeiro, Forense, 2000.

SILVESTRI, Elisabetta. The difficult art of legal transplants: the case of class actions, in Revista de Processo, vol. 187, setembro de 2010.

SOUZA, Miguel Teixeira. A tutela jurisdicional dos interesses difusos no direito português, in Revista de Processo, vol. 128, outubro de 2005.

. Legitimidade processual e ação popular no direito do ambiente, in Revista de Processo, n. 76, ano 19, outubro a dezembro de 1994, pp. $127 / 140$.

STIGLITZ, Gabriel A. Las acciones colectivas en proteccion del consumidor, in Revista de Direito do Consumidor, vol. 15, julho de 1995.

TARZIA, Giuseppe. La tutela inibitoria contro le clausole vessatorie, in Revista de Processo, vol. 114, março de 2004.

Legitimazione e partecipazione delle associazioni di categoria ai processi civili con rilevanza collettiva, in Participação e processo (coord. Ada Pellegrini Grinover, Cândido Rangel Dinamarco e Kazuo Watanabe), São Paulo, Revista dos Tribunais, 1988.

THEODORO JR., Humberto. Ações individuais e coletivas sobre relações de consumo reunião de processos por conexão, in Revista Síntese de Direito Civil e Processual Civil, n. 37, 2005.

. Arbitragem e terceiros - litisconsórcio fora do pacto arbitral - outras intervenções de terceiros, in Revista de Direito Bancário e do Mercado de Capitais, vol. 14, outubro de 2001.

Processo de execução, 19ª ed., LEUD, São Paulo, 1999.

TESHEINER, José Maria Rosa, e MILHORANZA, Mariângela Guerreiro. Direitos indisponíveis e legitimação do Ministério Público para as ações coletivas relativas a direitos individuais homogêneos de natureza previdenciária, in Revista de Processo, ano 34, n. 173, julho de 2009.

TROCKER, Nicolò, Enrico Allorio e la dottrina della riflessione della coisa giudicata rispetto ai terzi, in Rivista di Diritto Processuale, vol. 56, n. 2, abril a junho de 2001. 
VELLANI, Vellani. Naturaleza de la coza juzgada, Buenos Aires, Ediciones Juridicas Europa-America, 1963.

VELLOSO, Adolfo Alvarado. La prueba judicial (reflexiones críticas sobre la confirmación procesal), Valência, Tirant to Blanch, 2006.

VENTURI, Elton. A competência jurisdicional na tutela coletiva, in Direito Processual Coletivo e o anteprojeto de Código Brasileiro de Processos Coletivos, São Paulo, Revista dos Tribunais, 2007.

. Liquidação e execução coletiva da fluid recovery referente à 'Sobra' do empréstimo compulsório cobrado pela União e não devolvido, in Revista de Processo, vol. 111, julho de 2003.

. Processo Civil Coletivo - A tutela jurisdicional dos direitos difusos, coletivos e individuais homogêneos no Brasil - Perspectivas de um Código Brasileiro de Processo Coletivos, São Paulo, Malheiros, 2007.

VERBIC, Francisco. El proyecto de reformas a la Ley General del Ambiente 25.675 - en búsqueda de un sistema procesal colectivo para la reparación del daño ambiental en la República Argentina, in Revista de Processo, vol. 157, março de 2009.

VESCOVI, Enrique. Manual de Derecho Procesal - Actualizado según el Código General del Proceso, Montevidéu, Idea, 1990.

VIEIRA, Anginaldo. $\mathrm{O}$ sentido da Constituição, disponível em <http://www.dpu.gov.br/pdf/artigos/ArtigoAnginado.pdf>, acesso em 15/04/2011.

VIEIRA, Fernando Grella. A transação na esfera da tutela dos interesses difusos e coletivos: compromisso de ajustamento de conduta, in Ação Civil Pública - Lei 7.347/1985 - 15 anos (coord. Édis Milaré), 2a ed., São Paulo, Revista dos Tribunais, 2002.

VIGLIAR, José Marcelo Menezes. Defendant class action brasileira, in Direito Processual Coletivo e o anteprojeto de Código Brasileiro de Processos Coletivos, São Paulo, Revista dos Tribunais, 2007.

Interesses individuais homogêneos e seus aspectos polêmicos, $2^{\mathrm{a}}$ ed., São Paulo, Saraiva, 2008.

Questões atuais sobre o mandado de segurança coletivo, in Revista do Advogado, n. 64, ano XXI, junho de 2001. . Tutela jurisdicional coletiva, $1^{\mathrm{a}}$ e $3^{\mathrm{a}}$ ed., São Paulo, Atlas, 1998 e 2001. 
VIGORITI, Vincenzo. Interessi collettivi e processo: la legitimazione ad agire, Milão, Giuffrè, 1979.

. L'azione risarcitoria di classe: sollecitazioni europee, resistenze italiane, in Revista de Processo, vol. 180, fevereiro de 2010.

WAMBIER, Luiz Rodrigues, e WAMBIER, Teresa Arruda Alvim. Anotações sobre a liquidação e a execução das sentenças coletivas, in Direito Processual Coletivo e o anteprojeto de Código Brasileiro de Processos Coletivos, São Paulo, Revista dos Tribunais, 2007.

, et. al. Breves comentários à nova sistemática processual civil - 3, São Paulo, Revista dos Tribunais, 2007.

, et. al. Curso Avançado de Processo Civil, vol. 2, $4^{\text {a }}$ ed., São Paulo, Revista dos Tribunais, 2001. Liquidação de sentença, São Paulo, Revista dos Tribunais, 1997.

WAMBIER, Teresa Arruda Alvim, e WAMBIER, Luiz Rodrigues. Anotações sobre a liquidação e a execução das sentenças coletivas, in Direito Processual Coletivo e o anteprojeto de Código Brasileiro de Processos Coletivos, São Paulo, Revista dos Tribunais, 2007.

. Litispendência em ações coletivas, in Tutela coletiva: 20 anos da Lei da Ação Civil Pública e do Fundo de Defesa de Direitos Difusos - 15 anos do Código de Defesa do Consumidor (coord. Paulo Henrique dos Santos Lucon), São Paulo, Atlas, 2006.

Nulidades do processo e da sentença, $6^{\mathbf{a}}$ ed., São

Paulo, Revista dos Tribunais, 2007.

, et. al. O Dogma da coisa julgada - hipóteses de relativização, São Paulo, Revista dos Tribunais, 2003.

Reflexões sobre o ônus da prova, in Processo civil: estudos em comemoração aos 20 anos de vigência do Código de processo civil, São Paulo, Saraiva, 1995.

WATANABE, Kazuo, et. al. Código Brasileiro de Defesa do Consumidor comentado pelos autores do anteprojeto, $6^{\mathrm{a}}, 9^{\mathrm{a}}$ e $10^{\mathrm{a}}$ ed. (vol. II), Rio de Janeiro, Forense Universitária, 2000, 2007 e 2011. 
- Cultura da sentença e cultura da pacificação, in Estudos em Homenagem à Professora Ada Pellegrini Grinover (Flávio Luiz Yarshell e Maurício Zanoide de Moraes coord.), São Paulo, DPJ, 2005.

. Da cognição no processo civil, São Paulo, Revista dos Tribunais, 1987.

Demandas coletivas e os problemas emergentes da práxis forense, in Revista de Processo, n. 67, julho a setembro de 1992.

Juizado Especial de Pequenas Causas, São Paulo, Revista dos Tribunais, 1985.

Tutela jurisdicional dos interesses difusos: a legitimação para agir, in A tutela dos interesses difusos (coord. Ada Pellegrini Grinover), São Paulo, Max Limonad, 1984.

YARSHELL, Flávio Luiz. Antecipação da prova sem o requisito da urgência e direito autônomo à prova, São Paulo, Malheiros, 2009.

, e BONÍCIO, Marcelo José Magalhães, Execução civil - novos perfis, São Paulo, RCS, 2006.

. Observações a propósito da liquidação na tutela de direitos individuais homogêneos, in Atualidades sobre liquidação de sentença (Teresa Arruda Alvim Wambier org.), São Paulo, Revista dos Tribunais, 1997.

. Tutela coletiva e deveres em matéria probatória, in Em defesa de um Novo Sistema de Processos Coletivos - Estudos em Homenagem a Ada Pellegrini Grinover (coord. Maria Clara Gozzoli, Mirna Cianci, Petrônio Calmon e Rita Quartieri), São Paulo, Saraiva, 2010.

. Tutela jurisdicional, $1^{\mathrm{a}}$ e $2^{\mathrm{a}}$ ed., São Paulo, Atlas, 1999 e 2006.

. Tutela jurisdicional específica nas obrigações de declaração de vontade, São Paulo, Malheiros, 1993.

ZACLIS, Lionel. Proteção coletiva dos investidores no mercado de capitais, São Paulo, Revista dos Tribunais, 2007.

ZANELLATO, Marco Antonio. A defesa dos interesses individuais homogêneos dos consumidores pelo Ministério Público, disponível em $<$ http://www.aasp.org.br/aasp/servicos/revista_advogado/revista89/marco_zanellato.as p>, acesso em 23/08/2011.

ZANETI JR., Hermes, DIDIER JR., Fredie. Curso de Direito Processual Civil - Processo coletivo, vol. IV, $4^{\text {a }}$ ed., Salvador, Juspodivm, 2009. 
La tutela de los derechos difusos, colectivos e individuales homogéneos, $2^{\mathrm{a}}$ ed., México, Porrúa, 2004.

ZARIF, Cláudio Cintra. Ônus da prova nas ações coletivas, in Aspectos Processuais do Código de Defesa do Consumidor (coord. Fabiano Carvalho e Rodrigo Barioni), vol. I, São Paulo, Revista dos Tribunais, 2008.

ZAVASCKI, Teori Albino. Comentários à Nova Lei do Mandado de Segurança (coord. Napoleão Nunes Maia Filho, Caio Cesar Vieira Rocha e Tiago Asfor Rocha Lima), São Paulo, Revista dos Tribunais, 2010.

. Ministério Público, ação civil pública e defesa de direitos individuais homogêneos, Revista Forense, vol. 333, ano 92, janeiro a março de 1996.

Processo coletivo: tutela de direitos coletivos e tutela coletiva de direitos, $1^{\text {a e }} 4^{\text {a }}$ ed., São Paulo, Revista dos Tribunais, 2006 e 2009.

ZUFELATO, Camilo. Ação coletiva passiva no direito brasileiro: necessidade de regulamentação legal, in Em Defesa de um novo sistema de processos coletivos Estudos em Homenagem a Ada Pellegrini Grinover, São Paulo, Saraiva, 2010.

Sites visitados:

www.aasp.org.br

www.buzer.de

www.dpu.gov.br

http://egacal.e-ducativa.com

http://eur-lex.europa.eu

www.jfsp.jus.br

www.justice.gov.uk

www.law.cornell.edu

www.legisrn.gov.ar

www.migalhas.com.br

www.parlamento.it

www.revistadostribunais.com.br

www.scarpinellabueno.com.br

www.stf.jus.br

www.stj.jus.br

www.tjsp.jus.br

www.tre-pb.gov.br

www.uscourts.gov 